

\section{Cover credit}

Photos: Wescott, Konstance (Argonne National Laboratory).

From top to bottom (and left to right): La Garita (Oct. 2014), La Ventana (Oct. 2014),

Great Sand Dunes (May 2014), Our Lady of Guadalupe Church (Sept. 2014), Blanca Peak (July 2009),

rock art (Sept. 2014), irrigation ditch (July 2009), agricultural fields near San Luis (Oct. 2014),

Rio Grande del Norte National Monument (May 2014).

\section{About Argonne National Laboratory}

Argonne is a U.S. Department of Energy laboratory managed by UChicago Argonne, LLC under contract DE-AC02-06CH11357. The Laboratory's main facility is outside Chicago,

at 9700 South Cass Avenue, Argonne, Illinois 60439. For information about Argonne

and its pioneering science and technology programs, see www.anl.gov.

\section{DOCUMENT AVAILABILITY}

Online Access: U.S. Department of Energy (DOE) reports produced after 1991 and a growing number of pre-1991 documents are available free via DOE's SciTech Connect (http://www.osti.gov/scitech/).

Reports not in digital format may be purchased by the public from the National Technical Information Service (NTIS):

U.S. Department of Commerce

National Technical Information Service

5301 Shawnee Road

Alexandria, VA 22312

www.ntis.gov

Phone: (800) 553-NTIS (6847) or (703) 605-6000

Fax: (703) 605-6900

Email: orders@ntis.gov

Reports not in digital format are available to DOE and DOE contractors from:

U.S. Department of Energy

Office of Scientific and Technical Information

P.O. Box 62

Oak Ridge, TN 37831-0062

\section{Disclaimer}

This report was prepared as an account of work sponsored by an agency of the United States Government. Neither the United States Government nor any agency thereof, nor UChicago Argonne, LLC, nor any of their employees or officers, makes any warranty, express or implied, or assumes any legal liability or responsibility for the accuracy, completeness, or usefulness of any information, apparatus, product, or process disclosed, or represents that its use would not infringe privately owned rights. Reference herein to any specific commercial product, process, or service by trade name, trademark, manufacturer, or otherwise, does not necessarily constitute or imply its endorsement, recommendation, or favoring by the United States Government or any agency thereof. The views and opinions of document authors expressed herein do not necessarily state or reflect those of the United States Government or any agency thereof. 


\section{San Luis Valley - Taos Plateau Landscape-Level Cultural Heritage Values and Risk Assessment Final Report}

Konnie L. Wescott, ${ }^{1}$ Jennifer M. Abplanalp, ${ }^{1}$ Jeff Brown, ${ }^{2}$ Brian Cantwell, ${ }^{1}$ Merrill Dicks, ${ }^{3}$ Brian Fredericks, ${ }^{2}$ Angie Krall, ${ }^{4}$ Katherine E. Rollins, ${ }^{1}$ Robert Sullivan, ${ }^{1}$ Arnie Valdez, ${ }^{5}$ Bruce Verhaaren, ${ }^{1}$ Joseph Vieira, ${ }^{2}$ Lee Walston, ${ }^{1}$ Emily A. Zvolanek ${ }^{1}$

${ }^{1}$ Environmental Science Division, Argonne National Laboratory, Argonne, Illinois

2 Bureau of Land Management, San Luis Valley Field Office, Monte Vista, Colorado

${ }^{3}$ Bureau of Land Management, Taos Field Office, New Mexico

${ }^{4}$ U.S. Forest Service, Rio Grande National Forest, Colorado

${ }^{5}$ University of New Mexico, Albuquerque, New Mexico

Prepared for

Bureau of Land Management

Prepared by

Argonne National Laboratory

October 2016 



\section{ACKNOWLEDGMENTS}

The San Luis Valley - Taos Plateau Landscape-Level Cultural Heritage Values and Risk Assessment is a Bureau of Land Management (BLM) pilot project that supports the Colorado Solar Regional Mitigation Strategy (CO SRMS) for three solar energy zones designated in the San Luis Valley, Colorado. This project is a joint effort of a core cultural team comprised of Argonne National Laboratory (Argonne) archaeology, ecology, visual resources, and geographic information system (GIS) staff (Konnie Wescott - Principal Investigator - and Jennifer Abplanalp, Bruce Verhaaren, Lee Walston, Katie Rollins, Bob Sullivan, Emily Zvolanek, and Heidi Hartmann), BLM CO SRMS Project Manager Joe Vieira, Lead Forest Service archaeologist Angie Krall, Lead San Luis Valley BLM archaeologist Brian Fredericks, Lead Taos Field Office archaeologist Merrill Dicks, and Front Range District BLM realty specialist Jeff Brown. The pilot was funded by BLM-Colorado. Early on, the core team received exceptional support during an opening interagency kickoff workshop in May 2014 from Kate Winthrop, BLM Washington DC Office archaeologist; Fred Bunch, Great Sand Dunes National Park and Preserve archaeologist; Erin Hegberg, Forest Service archaeologist; Brian Cantwell, former Argonne GIS specialist; Doug Simon, BLM GIS specialist; and Arnie Valdez, adjunct associate professor in the School of Architecture and Planning at the University of New Mexico. These individuals brought the experience from various agencies and projects to benefit discussions of data sources, issues, methodology, and those highest level resources of significant cultural value. Data were graciously provided by the Colorado and New Mexico State Historic Preservation Offices, the National Trails Program within the National Park Service, and BLM and Forest Service GIS staff. Much of the environmental and change agent data was compiled by Lee Walston as part of a sister effort in the San Luis Valley - Taos Plateau Level IV Ecoregion Landscape Assessment (Walston et al. 2016). Meg Van Ness, U.S. Fish and Wildlife Service Region 6 archaeologist, provided helpful insight and thoughts on the regional data and models. We received excellent support from the BLM SRMS Assessment Management Team throughout the process as we provided updates: Andrew Archuleta, Melanie Barnes, Tom Heinlein, Paul Tigan, Dan Haas, and Bruce Rittenhouse, as well as from the BLM Washington Office Cultural Heritage staff: Byron Loosle, Kate Winthrop, and Emily Palus. Finally, an excellent peer-review workshop team provided comments at a November 2015 workshop; the team included Kirk Halford, BLM Idaho Deputy Preservation Officer; Dan Martin, Washington Office geospatial archaeologist; Jamie Palmer, Cedar City Field Office archaeologist; Nancy Keohane, BLM acting project manager for Colorado Renewable Energy Team; Meg Van Ness, USFWS archaeologist; Mary Sullivan, CO Office of Archaeology and Historic Preservation Information Management Director; Jan Biella, NM Deputy State Historic Preservation Officer and State Archaeologist; Christina Gallegos, Executive Director of the Sangre de Cristo National Heritage Area; Arnie Valdez, University of New Mexico; Lane Cowger, AZ BLM Renewable Energy Coordination Office Project Manager; Cynthia Herhan, BLM NM State Office cultural resource specialist; Art Hutchinson, National Park Service-Intermountain Region Chief of Planning; Karla Rogers, BLM National Operations Center; Rob Sweeten, UT BLM landscape architect and BLM Old Spanish National Historic Trail National Trail Administrator; Doug Simon, San Luis Valley BLM GIS specialist; and Kate Winthrop, Washington Office archaeologist. Several others were invited to participate in the peer-review workshop but were unable to attend. 


\section{PREFACE}

The San Luis Valley - Taos Plateau Landscape-Level Cultural Heritage Values and Risk Assessment (hereafter referred to as cultural assessment) is a BLM pilot project designed to see whether the Rapid Ecoregional Assessment (REA) framework (already established and implemented throughout many ecoregions in the West) can be applied to the cultural environment. The San Luis Valley - Taos Plateau is a Level IV ecoregion, slightly smaller than the Level III ecoregions typically studied for the REAs, but it is of a scale that is well-suited for the cultural assessment. The Level IV ecoregional boundaries correspond well to landscape features that have defined the cultural movements, land uses, and viewsheds within the area for thousands of years and that continue today. A fundamental purpose of the assessment is not only to capture data regarding the past activities that have shaped the collective history and cultural heritage of the region, but to get a glimpse of the future and how various change agents (human development, climate change, wildfire, and invasive species) might affect those resources. The expert knowledge of experienced Bureau of Land Management (BLM), Forest Service, National Park Service, and U.S. Fish and Wildlife Service cultural heritage/archaeology staff and many others who have lived and worked in the San Luis Valley - Taos Plateau were critical in the assessment for identifying conservation elements and establishing the baseline data set of what is currently known and culturally valued at the ecoregional scale.

The cultural assessment pilot was initiated with a multi-agency kickoff workshop in the San Luis Valley in May 2014. The pilot was introduced to public stakeholders in early September 2014 at the first public workshop on the Colorado Solar Regional Mitigation Strategy (CO SRMS) at Adams State University. At that time, the project was just getting started; data were still being collected and a model was being hypothesized for how the process might continue to unfold. Stakeholders were receptive to extending the REA concept, which was predominantly associated with ecological resources, to the human dimension. In late October, the status of the pilot project was presented to several tribes and federal agencies that were present in Del Norte, Colorado, for a meeting of the San Luis Valley Native American Graves Protection and Repatriation Act Working Group. The academic community was informed of the project at the Society for American Archaeology meetings in San Francisco in April 2015. Tribes present at the Mt. Blanca Summit at Fort Garland were updated again in May 2015. Stakeholders were also updated on the project's progress in May 2015 in conjunction with another public workshop on the CO SRMS. A final peer-review workshop for the cultural assessment was held in midNovember 2015 with subject-matter-expert representatives from many agencies, including BLM (CO, DC, ID, and UT), Forest Service, National Park Service, U.S. Fish and Wildlife Service, the Sangre de Cristo National Heritage Area, CO State Historic Preservation Office (SHPO) and NM SHPO, and a professor from the University of New Mexico, who helped contribute to the Hispano resources conservation element. 


\section{CONTENTS}

ACKNOWLEDGMENTS ............................................................................ V

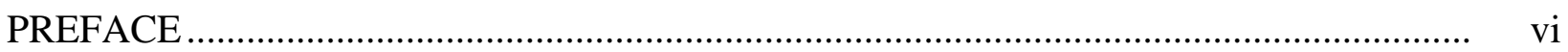

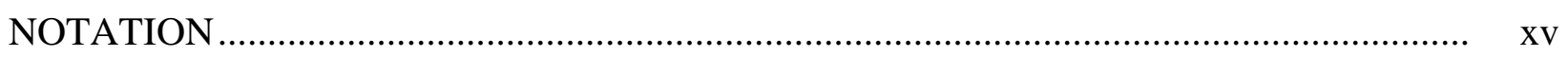

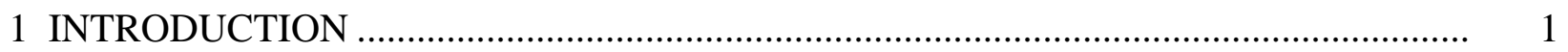

1.1 Purpose of the San Luis Valley - Taos Plateau Landscape-Level Cultural

Heritage Values and Risk Assessment ................................................................ 2

1.2 Elements of the Landscape-Level Cultural Heritage Values and Risk Assessment.... 3

1.2.1 Management Questions............................................................................ 3

1.2.2 Cultural Conservation Elements .............................................................. 4

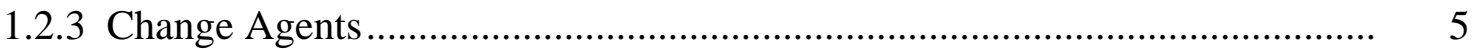

1.2.4 Cultural Landscape Condition Model........................................................ 5

1.3 Assumptions, Limitations, and Data Gaps............................................................. 6

2 BACKGROUND ON THE SAN LUIS VALLEY - TAOS PLATEAU ECOREGION ..... 9

2.1 Environmental Setting ............................................................................................ 9

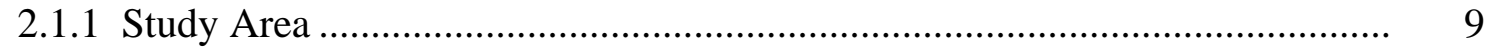

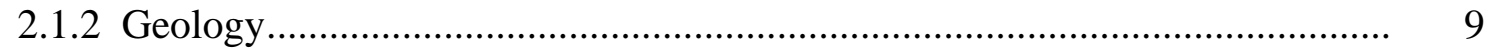

2.1.3 Hydrology ..................................................................................... 12

2.1.4 Minerals ..................................................................................... 12

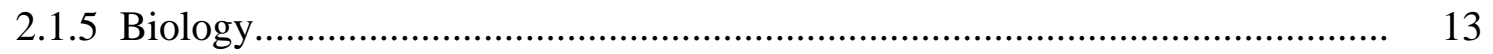

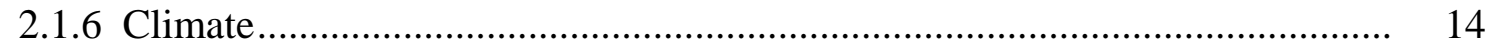

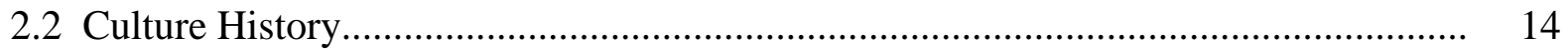

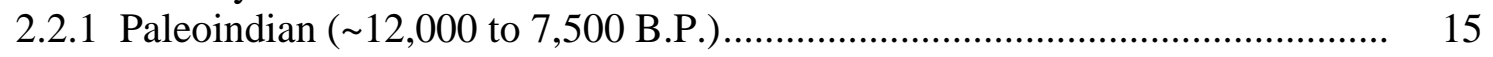

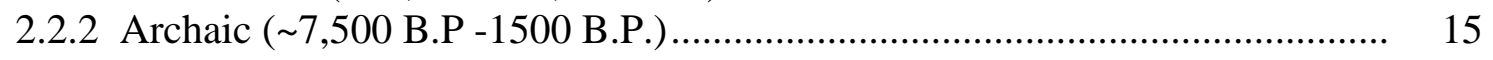

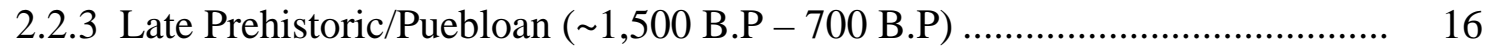

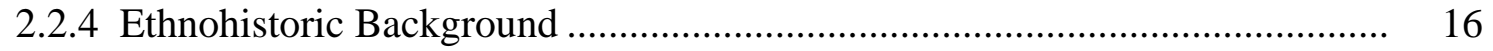

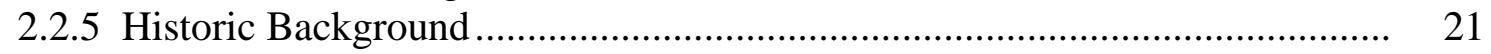

2.2.5.1 Spanish Exploration .................................................................. 21

2.2.5.2 American Exploration ................................................................. 22

2.2.5.3 American Military Conflict .......................................................... 22

2.2.5.4 Spanish and Mexican Land Grants................................................ 23

2.2.5.5 Trading and Trapping................................................................ 32

2.2.5.6 Early Hispano Settlement/Early Farming and Ranching ............... 32

2.2.5.7 Late $19^{\text {th }}$ Century/Early $20^{\text {th }}$ Century Agriculture and Settlement (1870-1930) ......................................................................... 34

2.2.5.8 Modern Agriculture (1945-Present) ............................................ 35

2.2.5.9 Mining .............................................................................. 36

2.2.5.10 Trails and Transportation ...................................................... 38

2.2.5.11 Urbanization .......................................................................... 41

2.2.5.12 Ethnic and Religious Influence ................................................ 42

2.2.5.13 Recreation and Government.................................................... 42 
3.1 Places of Traditional Cultural Importance to Tribes.................................................... 45

3.1.1 Data Needs and Research Avenues ............................................................. 46

3.1.2 Research and Land Use Management Questions............................................. 46

3.2 Traditional Resource Collection Areas ....................................................................... 47

3.2.1 Data Needs and Research Avenues ............................................................... 47

3.2.2 Research and Land Use Management Questions.............................................. 48

3.3 Trails, Passes, and Travel Corridors ...................................................................... 48

3.3.1 Data Needs and Research Avenues .............................................................. 49

3.3.2 Research and Land Use Management Questions.............................................. 49

3.4 Hispano Land Grants, Communal Use Patterns, and Places of Traditional

Cultural Importance ..................................................................................... 50

3.4.1 Data Needs and Research Avenues ......................................................... 51

3.4.2 Research and Land Use Management Questions.......................................... 52

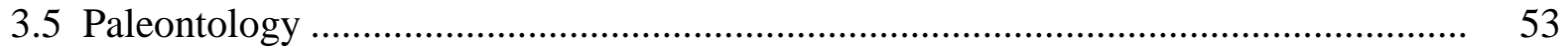

3.5.1 Data Needs and Research Avenues ............................................................. 54

3.5.2 Research and Land Use Management Questions............................................. 54

3.6 Eligible Prehistoric Properties ...................................................................................... 54

3.6.1 Data Needs and Research Avenues .............................................................. 54

3.6.2 Research and Land Use Management Questions.............................................. 55

3.7 Eligible Historic Properties.......................................................................................... 57

3.7.1 Data Needs and Research Avenues .............................................................. 58

3.7.2 Research and Land Use Management Questions............................................. 59

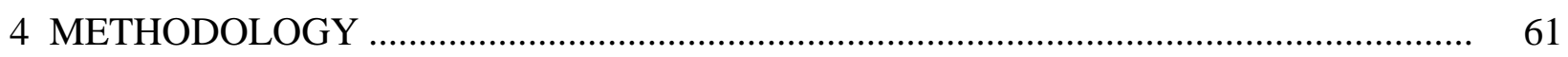

4.1 Data Collection and Management.......................................................................... 61

4.1.1 Data Collection .......................................................................................... 61

4.1.2 Data Management ................................................................................. 63

4.2 Models...................................................................................................... 63

4.2.1 Cultural Resources of Concern ...................................................................... 66

4.2.1.1 Cultural Resources of Concern Union Model .................................. 66

4.2.1.2 Cultural Resources of Concern Coincidence Model ......................... 66

4.2.1.3 Cultural Resources of Concern Scoring Model................................. $\quad 70$

4.2.2 Change Agents and Cultural Landscape Condition Model .............................. $\quad 70$

4.2.3 Archaeological Research Potential Model........................................................ $\quad 72$

4.2.4 Viewshed Value Model .................................................................................. 77

4.2.5 Cultural Resource Values Model................................................................... $\quad 79$

4.2.6 Change Agent Risk Model................................................................... $\quad 79$

4.2.7 Mitigation Potential Model ............................................................................. 85

5 EVALUATION OF CURRENT AND FUTURE CONDITIONS ..................................... 91

6 LESSONS LEARNED AND FUTURE CONSIDERATIONS.............................................. 99

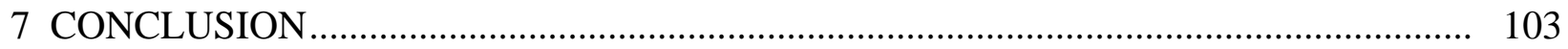

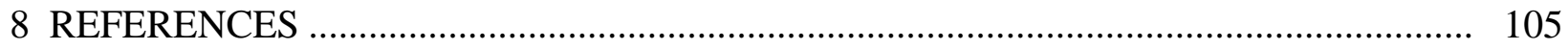


APPENDIX A: MANAGEMENT QUESTIONS.................................................................. A-1

A.1 MQI1: Where do areas of cultural resource management and protection occur?....... A-5

A.2 MQI2: Where are known historic properties, traditional cultural properties, and sacred sites and landscapes?

A.3 MQI3: What are the traditional cultural land use patterns?

A.4 MQI4: Where are the known historic properties, traditional cultural properties, and sacred sites vulnerable to change agents?

A.5 MQI5: Where are high potential areas or high density areas for historic properties that address the highest priority research goals?

A.6 MQI6: Where is cultural landscape connectivity vulnerable to change agents (human development, fire, invasive species, climate change)?

B.1 Places of Traditional Cultural Importance to Tribes

B.2 Traditional Resource Collection Areas

B.3 Trails, Passes, and Travel Corridors.

B.4 Hispano Land Grants, Communal Use Patterns, and Places of Traditional Cultural Importance

B.5 Paleontology

B.6 Eligible Prehistoric Properties.

B.7 Eligible Historic Properties B-61

\section{FIGURES}

2-1 The San Luis Valley - Taos Plateau Study Area .............................................. 10

2-2 $\quad$ Land Grants within the San Luis Valley - Taos Plateau Study Area ..................... 31

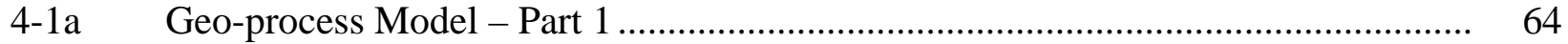

4-1b Geo-process Model - Part 2 …..................................................................... 65

4-2 Cultural Resources of Concern Union Model ................................................ 67

4-3 Cultural Resources of Concern Coincidence Model (Resources) .......................... 68

4-4 Cultural Resources of Concern Coincidence Model (Conservation Elements) ........ 69

4-5 Cultural Resources of Concern Scoring Model................................................. 71

4-6 Current and Future Cultural Landscape Condition in the San Luis Valley - Taos

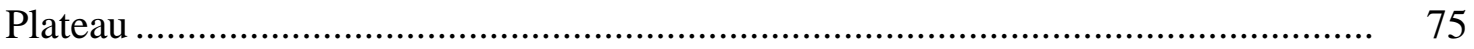

4-7 Archaeological Research Potential Model .......................................................... 


\section{FIGURES (Cont.)}

4-8 Key Observation Points for Cultural Resources with a Significant Visual Setting Component ....................................................................................... 78

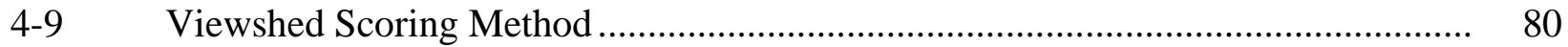

4-10 Viewshed Analysis of Cultural Resources within San Luis Valley - Taos Plateau Study Area (Sum)

4-11 Viewshed Analysis of Cultural Resources within San Luis Valley - Taos Plateau Study Area (Max)

4-12 Calculation of Cultural Resource Values (Coincidence) ...................................... 83

4-13 Calculation of Cultural Resource Values (Scored) ........................................... 84

4-14 Areas of Greatest Human Development Change in the Future .............................. 86

4-15 Calculation of Areas of Greatest Change Agent Risk Resulting from Projected Future Conditions

4-16 Intersection of High Cultural Value and High Change Agent Risk Models ............ 88

4-17 Intersection of High Cultural Value and Low Change Agent Risk Models.............. 89

5-1 Current Distribution of All Cultural Conservation Elements................................ 92

5-2 Current and Future Cultural Landscape Condition of All Cultural Conservation Elements

5-3 Intersection of Current Change Agents with All Cultural Conservation Elements

5-4 Intersection of Future Change Agents with All Cultural Conservation Elements .... 95

5-5 Predicted Trends in All Cultural Conservation Elements within the Study Area..... 96

A.1-1 Areas of Cultural Resources Management and Protection.................................... A-6

A.2-1 Locations of Known Cultural Resources within the Study Area ........................... A-8

A.3-1 Cultural Resources of Concern - Coincidence Model (Current distribution of known cultural resources with all cultural conservation elements combined).......... A-10

A.4-1 Potential Future Trend of Climate Change in the Study Area ............................... A-12

A.4-2 Potential Future Trend of Wildfire in the Study Area........................................... A-13

A.4-3 Potential Future Trend of Invasive Species in the Study Area.............................. A-14 


\section{FIGURES (Cont.)}

A.4-4 Potential Future Trend in Human Development ....................................................... A-15

A.4-5 Risk as a Result of Future Trends in Change Agents within the Study Area ............ A-16

A.5-1 Cultural Resource Values of Cultural Conservation Elements in the Study Area .... A-18

A.5-2 Risk as a Result of Future Trends in Change Agents within the Study Area ............ A-19

A.5-3 Areas of High Cultural Value and High Change Agent Risk ................................... A-20

A.5-4 Areas of High Cultural Value and Low Change Agent Risk .................................... A-21

A.6-1 Areas of High Cultural Value and High Change Agent Risk .................................... A-24

B.1-1 Current Distribution of Places of Traditional Cultural Importance to Tribes ............ B-14

B.1-2 Current and Future Landscape Condition of Places of Traditional Cultural Importance to Tribes ………………………………....................................... B-15

B.1-3 Intersection of Current Change Agents with Places of Traditional Cultural Importance to Tribes .............................................................................................. B-16

B.1-4 Intersection of Future Change Agents with Places of Traditional Cultural Importance to Tribes …………………………….............................................. B-17

B.1-5 Predicted Trends in Places of Traditional Cultural Importance to Tribes within the Study Area ................................................................................................ B-18

B.2-1 Current Distribution of Places of Traditional Resource Collection Areas................. B-20

B.2-2 Current and Future Landscape Condition of Traditional Resource Collection Areas.

B.2-3 Intersection of Current Change Agents with Traditional Resource Collection Areas.

B.2-4 Intersection of Future Change Agents with Traditional Resource Collection Areas

B.2-5 Predicted Trends in Traditional Resource Collection Areas within the Study Area

B.3-1 Current Distribution of Trails, Passes, and Travel Corridors..................................... B-26

B.3-2 Current and Future Landscape Condition of Trails, Passes, and Travel Corridors... B-27

B.3-3 Intersection of Current Change Agents with Trails, Passes, and Travel Corridors. 


\section{FIGURES (Cont.)}

B.3-4 Intersection of Future Change Agents with Trails, Passes, and Travel Corridors .... B-29

B.3-5 Predicted Trends in Trails, Passes, and Travel Corridors within the Study Area ..... B-30

B.4-1 Hispano Land Grants and Communal Land Use Patterns and Places of Traditional Cultural Importance

B.4-2 Current and Future Landscape Condition of Hispano Land Grants, Communal Use Patterns, and Places of Traditional Cultural Importance

B.4-3 Intersection of Current Change Agents with the Full Range of Hispano Concerns.

B.4-4 Intersection of Future Change Agents with the Full Range of Hispano Concerns ... B-35

B.4-5 Predicted Trends within the Full Range of Hispano Concerns …………….............. B-36

B.4-6 Current and Future Landscape Condition of National Heritage Areas ....................... B-37

B.4-7 Intersection of Current Change Agents with National Heritage Areas ....................... B-38

B.4-8 Intersection of Future Change Agents with National Heritage Areas......................... B-39

B.4-9 Predicted Trends in National Heritage Areas within the Study Area ........................ B-40

B.4-10 Current and Future Landscape Condition of Hispano Land Grants............................ B-41

B.4-11 Intersection of Current Change Agents with Hispano Land Grants.......................... B-42

B.4-12 Intersection of Future Change Agents with Hispano Land Grants .......................... B-43

B.4-13 Predicted Trends in Hispano Land Grants within the Study Area ............................. B-44

B.4-14 Current and Future Landscape Condition of the Hispano Conservation Element .... B-45

B.4-15 Intersection of Current Change Agents with the Hispano Conservation Element.... B-46

B.4-16 Intersection of Future Change Agents with the Hispano Conservation Element...... B-47

B.4-17 Predicted Trends in the Hispano Conservation Element within the Study Area....... B-48

B.5-1 Current Distribution of the Paleontology Conservation Element .............................. B-50

B.5-2 Current and Future Landscape Condition of the Paleontology Conservation Element.

B.5-3 Intersection of Current Change Agents with the Paleontology Conservation Element. B-52 


\section{FIGURES (Cont.)}

B.5-4 Intersection of Future Change Agents with the Paleontology Conservation

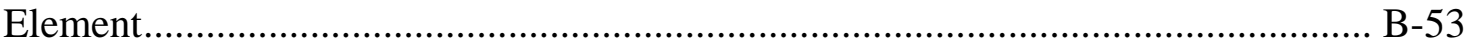

B.5-5 Predicted Trends in the Paleontology Conservation Element within the Study Area

B.6-1 Current Distribution of Eligible Prehistoric Properties........................................... B-56

B.6-2 Current and Future Landscape Condition of Eligible Prehistoric Properties ............ B-57

B.6-3 Intersection of Current Change Agents with Eligible Prehistoric Properties........... B-58

B.6-4 Intersection of Future Change Agents with Eligible Prehistoric Properties ............ B-59

B.6-5 Predicted Trends in the Eligible Prehistoric Properties Conservation Element within the Study Area................................................................................. B-60

B.7-1 Current Distribution of Eligible Historic Properties ............................................ B-62

B.7-2 Current and Future Landscape Condition of Eligible Historic Properties ................ B-63

B.7-3 Intersection of Current Change Agents with Eligible Historic Properties ................ B-64

B.7-4 Intersection of Future Change Agents with Eligible Historic Properties................. B-65

B.7-5 Predicted Trends in the Eligible Historic Properties Conservation Element within the Study Area.................................................................................. B-66

\section{TABLES}

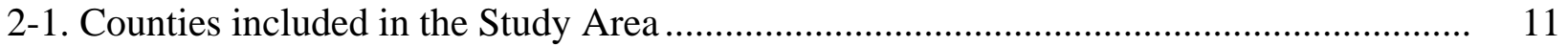

2-2. Land Jurisdiction within the Study Area ............................................................... 11

2-3. Land Grants within the San Luis Valley - Taos Plateau Study Area (after Center for Land Grant Studies 2005) ............................................................................... 25

4-1. Primary Documents Consulted for Narrative Data.................................................. 62

4-2. Current Cultural Landscape Condition Model .............................................................. 73

4-3. Future Cultural Landscape Condition Model............................................................ 74

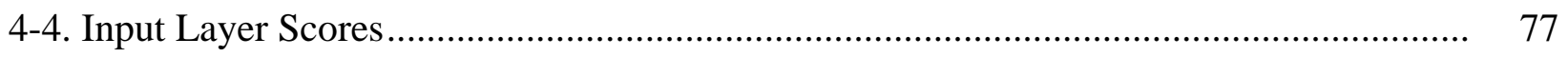

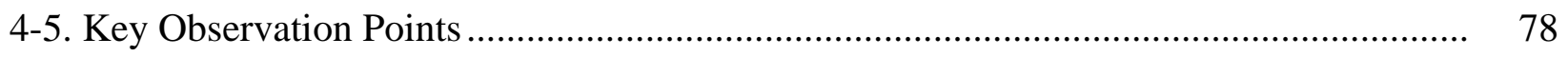

4-6. Viewshed Scores by Distance......................................................................... 80 


\section{TABLES (Cont.)}

A-1. Management Questions: Human and Cultural Elements.

A-4

A.1-1. Specially Designated Areas of Cultural Resource Management and Protection........... A-5

A.1-2. Federally Administered Lands and National Heritage Areas ....................................... A-5

B-1. Cultural Conservation Elements Evaluated in this Cultural Heritage Values and Risk Assessment ......................................................................................... B-4

B-2. Summary of Conservation Element Current and Future Potential Conditions................ B-8 


\section{NOTATION}

\section{ACRONYMS, INITIALISMS, AND ABBREVIATIONS}

\begin{tabular}{|c|c|}
\hline ACEC & Areas of Critical Environmental Concern \\
\hline Argonne & Argonne National Laboratory \\
\hline BLM & Bureau of Land Management \\
\hline CT\&SRR & Cumbres and Toltec Scenic Railroad \\
\hline DEM & digital elevation models \\
\hline D\&RG & Denver and Rio Grande Railroad \\
\hline EPA & Environmental Protection Agency \\
\hline GAO & Government Accounting Office \\
\hline GIS & geographic information system \\
\hline KOP & key observation point \\
\hline LCASB & Los Caminos Antiguos Scenic Byway \\
\hline NHA & National Heritage Area \\
\hline NHL & National Historic Landmark \\
\hline NHT & National Historic Trail \\
\hline NPS & National Park Service \\
\hline NRGNHA & Northern Rio Grande National Heritage Area \\
\hline NRHP & National Register of Historic Places \\
\hline OST & Old Spanish Trail \\
\hline RCC & Rio Culebra Cooperative \\
\hline REA & Rapid Ecoregional Assessment \\
\hline $\begin{array}{l}\text { SdCNHA } \\
\text { SEZ }\end{array}$ & $\begin{array}{l}\text { Sangre de Cristo National Heritage Area } \\
\text { solar energy zone }\end{array}$ \\
\hline SHPO & State Historic Preservation Office(r) \\
\hline SRMS(s) & Solar Regional Mitigation Strategy(ies) \\
\hline U.S.C. & United States Code \\
\hline USDOI & U.S. Department of the Interior \\
\hline USFS & U.S. Forest Service \\
\hline USFWS & U.S. Fish and Wildlife Service \\
\hline
\end{tabular}




\section{UNITS OF MEASURE}

$\mathrm{ft} \quad$ feet

$\mathrm{km}^{2} \quad$ square kilometer(s)

m meter(s)

mi mile(s)

\section{UNIT CONVERSIONS}

$\begin{array}{ll}1 \mathrm{~km}^{2} & 0.39 \mathrm{mi}^{2} \\ 1 \mathrm{~m} & 3.28 \mathrm{ft}\end{array}$




\section{INTRODUCTION}

In response to the increasingly complex and widespread environmental challenges affecting America's public lands and pursuant to the Federal Land Policy and Management Act multiple-use mandate, the Bureau of Land Management (BLM) has adopted a landscape-level approach to public land management intended to identify resource condition and trends, management strategies, and opportunities for resource conservation and development. The approach identifies important resource values and patterns of change on multiple scales across programmatic, organization, land ownership, and political boundaries (Winthrop 2014; BLM 2012). This approach provides baseline data for long-term monitoring and adaptive management efforts and allows the BLM to incorporate information about regional conditions, trends, and needs into its land and resource management decisions, and enhances BLM's land use planning processes to be more responsive to environmental and social change.

Rapid Ecoregional Assessments (REAs) have been a dominant undertaking by the BLM to provide a broad-scale synthesis of natural/ecological status and trends within a particular region, typically a Level III ecoregion. These assessments are tools that help the BLM implement U.S. Department of the Interior Secretarial Orders to use landscape approaches in evaluating impacts of climate change, energy development, and other activities occurring on public lands (USDOI 2010, 2013). The REAs characterize current status or condition of selected resources (identified as conservation elements) and forecast trends and future vulnerability of these resources based on their response to change agents. As of March 2016, 14 REAs have been initiated by the BLM; 10 have been completed, and 4 are in various stages of completion (BLM 2016a). These assessments use readily available data and rapid assessment approaches and geographic information system (GIS) analyses to address a range of regional management questions and identify data gaps requiring further study. They are intended to serve multiple purposes in natural resource management, including understanding landscape-level condition and trends of conservation elements; characterizing influences of change agents in the ecoregion; understanding landscape-level impacts of human development activities; informing the development of ecoregion-based conservation strategies; informing land use planning decisions (including regional mitigation opportunities); and providing baseline data for long-term monitoring and adaptive management activities (Walston et al. 2016).

The overall intent of the BLM's landscape approach is to consider broad-scale implications of land use and project planning; development, restoration, and conservation priorities; and cumulative effects analyses. To date, the BLM's landscape approach has been largely focused on ecological resources, but landscape-scale cultural resources assessments are beginning to be incorporated into the planning process. Cultural landscape assessments have been part of land use planning and historic preservation efforts for quite some time, particularly in Europe, Canada, and Australia, and, in more recent years, the United States. The BLM's cultural landscape approach is a paradigm shift from the traditional cultural resource management approach of looking at individual site locations on a project-by-project basis to a more holistic approach that analyzes historic and traditional land use patterns at a regional landscape scale. Although each cultural site is important on its own and has its own set of management requirements, a more comprehensive assessment of value and significance occurs when one considers the relationships of those sites to other places and features on the landscape 
(Lennon and Mathews 1996). Cultural landscape assessments consider the interaction between groups of people and their environment by looking at both the temporal and spatial relationships between traditionally defined archaeological sites and culturally important places and the traditional uses of the environment in general. In essence, cultural landscape assessments recognize the interaction between humans and their environment over time and the importance of that relationship.

\subsection{Purpose of the San Luis Valley - Taos Plateau Landscape-Level Cultural Heritage Values and Risk Assessment}

The BLM is systematically addressing the potential for unavoidable adverse impacts from utility-scale solar development on public lands through a series of Solar Regional Mitigation Strategies (SRMSs) for Solar Energy Zones (SEZs) throughout the West (see BLM 2014a; 2016b, c, and d). One of the tools to support these strategies is the REA, which synthesizes existing information about resource conditions and trends within an ecoregion, highlights and maps areas of high ecological value, and gauges the potential risk to these areas from change agents including climate change; wildfire; invasive species, insects, and disease; and human development.

In 2013, BLM completed a pilot study for regional compensatory mitigation at the Dry Lake SEZ in Nevada (BLM 2014a). Although the pilot project was specific to regional mitigation planning for utility-scale solar energy development, the related document informs future regional mitigation strategies for other types of development throughout the West. Guidance that emerged as a result of this study recommended the consideration of cultural resources at a landscape level to improve the intended outcome of SRMSs. The guidance also recommended the development of a regional research design that would help identify the most significant cultural resources in the region and support the identification of possible mitigation actions and locations.

In 2014, drawing upon guidance from the pilot program, the BLM developed a modified REA, the San Luis Valley - Taos Plateau Level IV Ecoregion Landscape Assessment (hereafter called the Landscape Assessment), for the area encompassing the four Colorado SEZs, which lie within the San Luis Valley - Taos Plateau. This assessment was conducted at a Level IV ecoregion level rather than a Level III, as it is a more appropriate scale for assessing resource conditions within the San Luis Valley - Taos Plateau and will provide more meaningful data for decision-making efforts. The Landscape Assessment provides an overarching mechanism for analyzing and explaining conditions and trends in the ecological environment at a landscape scale (Walston et al. 2016), but also refers to the studies that document cultural and visual environments in more detail (this study and Sullivan et al. 2016, respectively).

As part of the Landscape Assessment, the BLM funded the Landscape-Level Cultural Heritage Values and Risk Assessment pilot project documented in this report, to determine whether the REA framework, already established and implemented throughout many ecoregions in the West, can be applied to the cultural environment. The Level IV ecoregional boundaries of the San Luis Valley - Taos Plateau are well-suited for a cultural resources assessment, as they 
correspond well to landscape features that have defined the cultural movements, land uses, and viewsheds within the area for thousands of years and that continue today.

The overall purpose of the cultural heritage values and risk assessment (also referred to herein as the cultural assessment or cultural landscape assessment) is three-fold: (1) document the current status of the most important and at-risk cultural resources that have shaped the collective history and cultural heritage of the San Luis Valley - Taos Plateau; (2) evaluate the trends and vulnerability of these resources to change agents over time (human development, climate change, wildfire, and invasive species); and (3) help focus regional compensatory mitigation efforts on the most important and at-risk cultural resources in the region.

In conjunction with the cultural assessment, BLM and Argonne National Laboratory (Argonne) developed a regional research design to provide a context of existing cultural resources and their importance to local communities as well as their relationship to landscape features. The regional research design has identified research themes, data gaps, and research priorities to address key research questions. The regional research design provides a comprehensive understanding of the most valued and at-risk cultural resources and provides the context for understanding the value and importance for resources yet to be recorded or discovered.

The results of the cultural assessment will be integrated with the ecological and visual landscape assessments to provide a holistic view of the most valued and at-risk cultural and natural resources in the San Luis Valley - Taos Plateau. The dynamics between the people and the land of the San Luis Valley - Taos Plateau region are such that many residents still depend on the land for their survival and/or are connected to the land in a way that influences their wellbeing. These three assessments support a more holistic approach to land use planning by considering the relationships, both past and present, that people have to the land, as well as other cultural, or human, elements that are closely linked to the landscape.

\subsection{Elements of the Landscape-Level Cultural Heritage Values and Risk Assessment}

Similar to the Landscape Assessment, there are three major elements of this cultural assessment: management questions, cultural conservation elements, and change agents. Management questions guide the identification and evaluation of cultural conservation elements and how they interact with and may be influenced by change agents. A descriptive summary of the process involved in identifying management questions and change agents is provided in Walston et al. 2016.

\subsubsection{Management Questions}

Management questions relate to important resources and their attributes for addressing land management responsibilities (Walston et al. 2016). Management questions (MQs) were identified by the BLM interdisciplinary team and assessment management team during the development of the Landscape Assessment. The MQs are the foundation of the assessment and guide the selection of the conservation elements and the information needed to understand how change agents affect the conservation elements. Human and cultural management questions 
defined for the San Luis Valley - Taos Plateau are provided below in Table 1-1 and are addressed in more detail in Appendix A. This cultural assessment only addresses MQs I1-I6. The evaluation of MQI7 would involve data collection and model processing that was determined to be outside the scope of this assessment. A complete list of management questions for the entire Landscape Assessment can be found in Walston et al. 2016.

\subsubsection{Cultural Conservation Elements}

Cultural conservation elements were selected in consultation with the BLM interdisciplinary team for the SRMS after evaluating a variety of spatial and narrative data (see Section 4.1). A regionally significant cultural conservation element has attributes that give it more than local significance, especially compared to similar resources. However, because so little area within the ecoregion has been systematically surveyed for cultural resources, catchall cultural conservation elements have been considered, such as eligible prehistoric and historic properties. All information provided by the State Historic Preservation Offices (SHPOs) is included in this assessment, as well as the eligibility status for listing in the National Register of Historic Places in order to gauge significance. The selected cultural conservation elements brought forward in this assessment represent regionally significant focus areas and serve as the basis for the landscape-level cultural sensitivity layers. They are broad enough not to identify specific sensitive resource locations and can stand alone, but, when combined with each other, aid in the identification of potential avoidance areas (if in or near the SEZs) as well as prime candidate locations for regional mitigation of affected cultural landscapes. Seven cultural conservation elements were selected for evaluation in the San Luis Valley - Taos Plateau cultural assessment and are listed below in Table 1-2. Cultural conservation elements are discussed in detail in Section 3 and Appendix B.

\section{Table 1-1. Management Questions: Human and Cultural Elements}

MQI1 Where do areas of cultural resource management and protection occur (National Monuments, Areas of Critical Environmental Concern, National Historic Landmarks, World Heritage Areas, Scenic and Historic Byways, etc.)?

MQI2 Where are known historic properties, traditional cultural properties, and sacred sites and landscapes?

\begin{tabular}{ll}
\hline MQI3 & What are the traditional cultural land use patterns? \\
\hline MQI4 & $\begin{array}{l}\text { Where are known historic properties, traditional cultural properties, and sacred sites } \\
\text { vulnerable to change agents? }\end{array}$ \\
\hline MQI5 & $\begin{array}{l}\text { Where are high-potential areas or high-density areas for historic properties that } \\
\text { address the highest priority research goals? }\end{array}$ \\
\hline MQI6 & $\begin{array}{l}\text { Where is cultural landscape connectivity vulnerable to change agents (human } \\
\text { development, fire, invasive species, and climate change)? }\end{array}$ \\
\hline MQI7 & $\begin{array}{l}\text { Where are sensitive socioeconomic populations, and how are they affected by } \\
\text { change agents? }\end{array}$ \\
\hline
\end{tabular}




\section{Table 1-2. Cultural Conservation Elements}

Places of Traditional Cultural Importance to Tribes

Traditional Resource Collection Areas

Trails, Passes, and Travel Corridors

Hispano Land Grants, Communal Use Patterns, and Places of Traditional Cultural Importance

Paleontology

Eligible Prehistoric Properties

Eligible Historic Properties

\subsubsection{Change Agents}

The assessment of condition and trends for the cultural conservation elements evaluates natural and anthropogenic disturbance factors to understand the potential risk the cultural conservation elements may be facing from the change agents. Four primary change agents were evaluated in this assessment and are the same as those evaluated in the Landscape Assessment: (1) climate change; (2) human development; (3) invasive species, insects, and disease; and (4) wildfire. Human development includes grazing, recreation, and other agricultural practices, in addition to infrastructure development. Also note that the wildfire model does not include the controlled prescribed burns employed by the land management agencies. These change agents were chosen based on their regional importance for both ecological and cultural resources, and they typically have a negative effect on resources in the region. The reader is referred to the Landscape Assessment (Walston et al. 2016) for more detailed information regarding the change agents and their respective models typically used in the REAs.

\subsubsection{Cultural Landscape Condition Model}

The cultural landscape condition model is distinct from the landscape intactness model described in the Landscape Assessment. However, it serves a similar purpose for evaluating the condition and trends of the conservation elements in trying to characterize cultural integrity across the landscape. Of course, this is difficult to determine, because human activities both create the cultural landscape and disturb or destroy it. Although many aspects of the landscape intactness model for "naturalness" from an ecological perspective are still useful, some modifications to the model were made based on an understanding of the core cultural team about how cultural patterns can be disturbed and changed over time. More detail regarding the cultural landscape condition model is presented in Section 4.2. 


\subsection{Assumptions, Limitations, and Data Gaps}

One of the overarching requirements of the landscape-level cultural assessment is to use pre-existing data as assessment inputs; no field data collection or research was conducted in support of this assessment. This requirement, coupled with the objective of providing a rapid analysis, presented some challenges and limitations:

- Much of the study area has not been systematically surveyed for cultural resources. It is not possible to determine the presence/absence or potential of cultural resources in these areas without conducting additional research or using predictive models. If additional conservation elements or management questions are identified in the future as more research is completed in the ecoregion, they can be incorporated into the assessment using the methodology established in this document.

- The analysis presented in this assessment was conducted using a $1 \mathrm{~km}^{2}$ grid for a Level IV ecoregion. The intent is to provide landscape-scale information regarding the condition and trends for select cultural conservation elements. Additional information or analysis may be necessary for making decisions at other geographic scales (e.g., a local project scale).

- Existing digital data on particular cultural conservation elements (i.e., eligible prehistoric and historic properties) vary widely between databases and even within databases. In many cases, attribute data describing the details of the properties are sparse or missing all together, making it difficult to create a uniform dataset across the entire study area.

- This assessment was conducted using the best available data. Although representatives from the various agencies aimed to incorporate known stakeholder concerns, local residents and Native American tribes were not directly consulted for input into this initial pilot assessment. Every effort was made to incorporate areas of known importance to Native American tribes and local residents based on existing literature and previous studies. Data derived from past ethnographic assessments were used to inform areas of cultural importance to tribes and the Hispano community. Tribes and local stakeholders were apprised of the assessment during various meeting opportunities, including at least two interagency meetings with tribes and various stakeholder meetings tied to the BLM SRMS process.

- Although this document is meant to help inform land use planning activities throughout the San Luis Valley - Taos Plateau, this document should not be used as a substitute for community and stakeholder engagement or government-to-government consultation.

A number of additional data gaps were identified during the assessment process. These data gaps may be useful for directing future research. The highlights are summarized here, but future considerations are more fully discussed in Section 7. 
- Water (the availability, quality, and distribution of surface water and groundwater) was identified as a potential change agent that could influence the condition and trends of cultural conservation elements and should be addressed in the future.

- More detail regarding climate change would be useful in determining the direction of change, as opposed to the absolute value of a change regarding temperature and precipitation. This influences many factors that can impact cultural conservation elements, such as water availability and its contribution to erosional processes.

- Differences in agricultural methods are important when assessing the condition and trends of traditional cultural practices and the impacts on significant resources. These differences warrant further assessment. Because data were lacking to readily differentiate the methods spatially, it was not possible to incorporate the differences into the cultural landscape condition model (discussed in Section 4.2).

In addition, the impetus behind conducting the Level IV ecoregion cultural heritage values and risk assessment was the Solar Regional Mitigation Strategy and the need for condition and trend analysis for the ecological, cultural, and visual resources present within the San Luis Valley - Taos Plateau ecoregion. As a result, there are some solar-specific items addressed in this assessment as well as in the Landscape Assessment that would not likely occur in other similar documents. Also, because of that solar focus in the San Luis Valley portion of the ecoregion, there are some limitations and data gaps more evident for the New Mexico side of the ecoregion because data for that part of the study area were less readily available for incorporation into this assessment. 
Final SLV-TP Landscape-Level

October 2016

Cultural Heritage Values and Risk Assessment

Page Intentionally Left Blank 


\section{BACKGROUND ON THE SAN LUIS VALLEY - TAOS PLATEAU ECOREGION}

\subsection{Environmental Setting}

\subsubsection{Study Area}

The San Luis Valley - Taos Plateau Level IV Ecoregion encompasses approximately $9,786 \mathrm{mi}^{2}\left(25,346 \mathrm{~km}^{2}\right)$ and includes portions of southern Colorado and northern New Mexico (Figure 2-1). This figure also notes locations of the BLM Solar Energy Zones (SEZs) under consideration for regional mitigation planning that were the initial impetus for conducting this landscape-level cultural assessment. About 65\% of the study area occurs in Colorado and 35\% in New Mexico (Table 2-1), with portions of 12 counties in Colorado and 6 counties in New Mexico. Figure 2-1 also shows federal land jurisdiction. Federal land management accounts for $53.8 \%$ of the study area; Table $2-2$ provides the breakdown of land management within the ecoregion.

The study area is situated in a north-south dimension, with the longest north-south axis of approximately $172 \mathrm{mi}(277 \mathrm{~km})$ and longest east-west axis of approximately $95 \mathrm{mi}(153 \mathrm{~km})$. The dimensions of the study area are influenced by the two dominant mountain ranges in the region: the Sangre de Cristo Mountains to the east and the San Juan Mountains to the west. Elevations within the study area range from approximately 5,000 to $14,000 \mathrm{ft}$. $(1,524$ to $4,267 \mathrm{~m})$.

\subsubsection{Geology}

The San Luis Valley - Taos Plateau is an intermontane basin that is part of the larger Rio Grande Rift Zone which extends from the state of Chihuahua, Mexico to Leadville, Colorado. The study area includes the San Luis Valley - Taos Plateau as well as portions of the surrounding mountain ranges. The mountains and valley that comprise the study area were formed during an intense period of volcanic activity in the middle Tertiary. Remnants of this volcanism are scattered throughout the mountains and valley and include prominent geological formations such as San Antonio Peak, Ute Mountain, Cerra de Olla, and the San Luis Hills. The Great Sand Dunes are located on the eastern side of the valley at the western base of the Sangre de Cristo Mountains near Blanca Peak. Rising up to $750 \mathrm{ft}$. above the valley floor, they are the tallest dunes in North America. The sand dunes were formed from broken down volcanic rock sediments of the San Juan Mountains that were transported by the Rio Grande and deposited on the alluvial fan on the west side of the valley. The sand was then blown by southwesterly winds, piling up at the base of the mountains creating the dunes (Chapman et al. 2006; SdCNHA 2013; NRGNHA 2013). Most of the prominent geological formations in the valley are important to Native American tribes and the Hispano community of the San Luis Valley - Taos Plateau region.

Several passes provide access to the study area from the surrounding valleys and mountains. In the northernmost part of the study area, where the Sangre de Cristo and San Juan Mountains meet is Poncha Pass. In the northwest is Cochetopa Pass through the Cochetopa Hills. Passes through the Sangre de Cristo Mountains on the eastern side of the study area include 


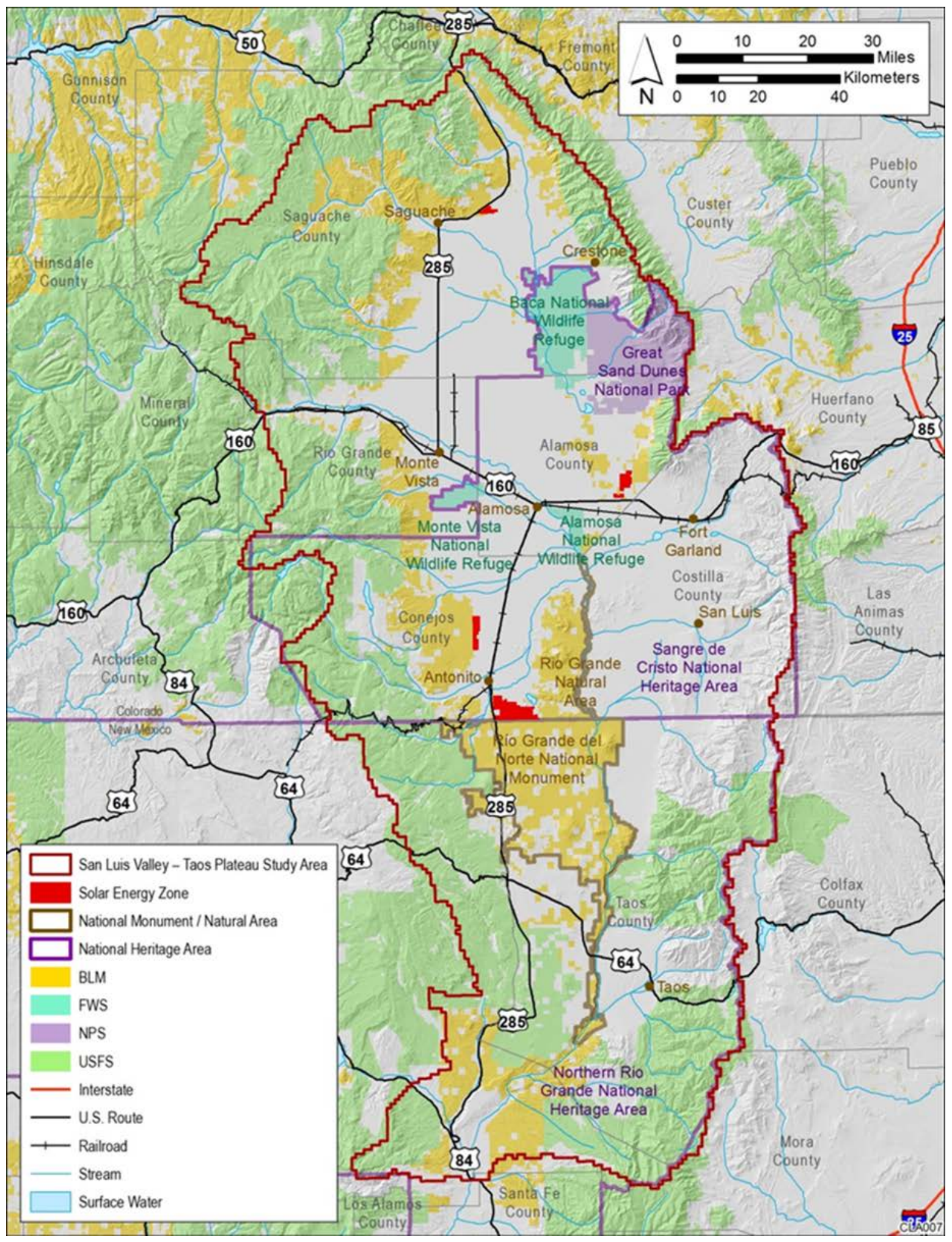

Figure 2-1. The San Luis Valley - Taos Plateau Study Area 
Table 2-1. Counties included in the Study Area

\begin{tabular}{|lr|}
\hline County & $\begin{array}{c}\text { Lands within } \\
\text { Study Area (mi } \mathbf{~}^{\mathbf{a}}\end{array}$ \\
\hline Colorado & \\
Saguache & 2387.6 \\
Costilla & 1202.8 \\
Conejos & 1153.5 \\
Rio Grande & 806.0 \\
Alamosa & 723.6 \\
Huerfano & 28.5 \\
Mineral & 15.3 \\
Custer & 13.4 \\
Fremont & 7.9 \\
Archuleta & 5.6 \\
Chaffee & 2.4 \\
Las Animas & 0.6 \\
New Mexico & \\
Taos & 2204.4 \\
Rio Arriba & 1191.3 \\
Colfax & 26.3 \\
Mora & 18.2 \\
Sandoval & 2.6 \\
Santa Fe & 2.2 \\
\hline To convert to $\mathrm{km}^{2}$, multiply by 2.59 \\
\hline
\end{tabular}

Table 2-2. Land Jurisdiction within the Study Area

\begin{tabular}{|l|r|r|}
\hline & & $\begin{array}{c}\text { Percent } \\
\text { of Study } \\
\text { Federal Land Management Agency or Owner }\end{array}$ \\
\hline Private & \multicolumn{1}{c|}{ Acres } & \multicolumn{1}{c|}{ Area } \\
U.S. Forest Service & $2,095,217$ & 41.2 \\
Bureau of Land Management & 921,031 & 33.4 \\
Local/State & 261,245 & 4.7 \\
National Park Service & 149,809 & 2.2 \\
Tribal Lands & 144,290 & 2.3 \\
U.S. Fish and Wildlife Service & 112,313 & 1.8 \\
\hline TOTAL & $6,226,010$ & 100.0 \\
\hline
\end{tabular}


Hayden, Medano, Music, San Francisco, Mosca, Sangre de Cristo, and North La Veta. Passes through the San Juan Mountains on the western side of the study area include Wolf Creek and Cumbres. From the south, access is provided through the Santa Fe and Taos Passes (Simmons 1999; Higgins et al. 2013). All of these were used historically and are discussed throughout Section 2.2.

For a detailed discussion of the physiography and geology of the study area the reader is directed to Andrew Taylor's (1999) Guide to the Geology of Colorado, the Sangre De Cristo National Heritage Area Management Plan (SdCNHA 2013) and the Northern Rio Grande National Heritage Area Management Plan (NRGNHA 2013).

\subsubsection{Hydrology}

There are numerous rivers, tributaries, and intermittent drainages within the study area. Larger rivers within the study area include the Conejos River, San Antonio River, Rio Chama, and the Rio Grande. Precipitation in the study area is low (6-12 inches a year), however, surface runoff in the form of rain and snowmelt from the surrounding mountains provide ample water to the region. Numerous drainages descend from the Sangre de Cristo and San Juan Mountains, including the above-mentioned rivers. The northern portion of the San Luis Valley is a closed basin, with no natural surface water drainage. Water enters this portion of the valley through precipitation and snowmelt and seeps into the aquifer, exits through evapotranspiration, or flows into San Luis Creek, and is impounded in San Luis Lake and other small lakes near Baca National Wildlife Refuge. The southern half of the study area is an open basin with mountains streams merging into streams and rivers that serve as tributaries to the Rio Grande. Aquifers and artesian wells supply ground and surface water in both basins (USFWS 2012; SdCNHA 2013).

Although the study area is considered a desert environment, lakes and wetlands are found throughout the valley. The San Luis Lakes are the largest of the perennial lakes in the study area and are surrounded by several smaller lakes. Clusters of lakes and wetlands are found within the Baca National Wildlife Refuge and Blanca Wetlands, in Saguache County; Alamosa National Wildlife Refuge in Alamosa County; and the Monte Vista National Wildlife Refuge in Rio Grande County. These lakes and wetlands once supported a large hunter-gatherer population (Chapman et al. 2006; SdCNHA 2013).

These waters are an important part of the rich and diverse ecosystem that supported prehistoric populations and later Native American, European and American explorers, farmers, and ranchers. Today, these streams and rivers as well as ninety-percent of wells that have been drilled in the valley are used for irrigation of commercial crops through either center-pivot irrigation or gravity-flow surface ditches, also known as acequias (SdCNHA 2013).

\subsubsection{Minerals}

Prehistoric people utilized local sources of stone available throughout the valley (Higgins et al. 2013 after Spero 2007). Chert, chalcedony, quartzite, rhyolite, basalt, turquoise and obsidian have been found at archaeological sites throughout the study area. Chert, chalcedony, quartzite and rhyolite are available in outcrops or as cobbles found throughout the 
mountains and valley. Basalt was likely procured at San Antonio Peak. The only known obsidian source in the valley is at Cochetopa Dome. The King Turquoise Mine, near Manassa, is known to have been mined prehistorically for turquoise before it was modernized in the 1920s.

Rock, sand and gravel are the major contemporary commodities mined within the study area. Gold, silver, peat, limestone, lead, clay, uranium, molybdenum and volcanic materials are also mined, but in lesser quantities (Colorado Division of Reclamation Mining \& Safety 2014; NRGNHA 2013). There are active exploratory oil and gas operations within the study area (USFWS 2012). Major historic mines throughout the valley mined metals such as iron, silver, gold, and uranium as well as precious stones such as turquoise, amethyst, and rock crystal. Historic mining is discussed further in Section 2.2.5.9.

For further information on the locations of rocks and mineral sources the reader is referred to Vince Spero's (2007) Distribution and Sources of Lithic Material in the Rio Grande Basin.

\subsubsection{Biology}

As described in the San Luis Valley - Taos Plateau Level IV Ecoregional Landscape Assessment (Walston et al. 2016), the study area is known for its high ecological values. The wide variety of vegetation types includes intermountain basins dominated by sagebrush shrublands and semi-desert shrub-steppe communities interspersed with wetlands and riparian areas and piñon-juniper forests, including volcanic cones rising upwards of 2,000-4,000 feet from the plateau with oak and mixed conifer forests of ponderosa pine, douglas fir, white pine and aspen, and other foothill woodland communities. High elevation mountain ranges around the periphery of the study area support montane and subalpine forests. Networks of basin wetlands within the study area are formed from snowmelt in the surrounding mountains and provide important habitat for over 200 species of migratory waterfowl and shorebirds as well as other wildlife, including many threatened, endangered, and sensitive species (USFWS 2012). The study area also provides important habitat for big game wildlife species - including bighorn sheep, elk, mule deer, and pronghorn - and supports one of the largest elk herds in New Mexico (Smallidge et al. 2003).

For more detail on flora and fauna species that can be found in the study area the reader is referred to The Draft Environmental Assessment and Land Protection Plan for the San Luis Valley Conservation Area (USFWS 2012) and the websites of the San Luis Valley National Wildlife Refuge Complex (USFWS 2014); the Colorado Parks and Wildlife (n.d.); and the New Mexico Department of Game and Fish (n.d.) (links provided in References). Further information regarding the conservation elements for the Landscape Assessment is available in Walston et al. 2016. For information on plant and animal resources that are important to Native American tribes and the Hispano community, the reader is directed to the following ethnographies: Seinanyédi: An Ethnographic Overview of Great Sand Dunes National Park and Preserve (portions redacted) (White 2005); Cultural Continuity, An Ethnographic Study Related to the Potential Solar Energy Development in San Luis Valley, Colorado (portions redacted) (Higgins et al. 2013); and Ethnohistoric and Ethnographic Assessment of Contemporary Communities along the Old Spanish Trail (Stoffle et al. 2008). 


\subsubsection{Climate}

The climate of the study area is characterized by cool summers and very cold winters in both the mountain and valley regions. Weather reporting stations in Alamosa and Wolf Creek illustrate the similarities and differences in weather patterns within the study area (Colorado Climatic Data Center 2014). Average daily temperatures in both the valley and mountain regions can differ by 30 degrees between day and night and average precipitation varies greatly between the two regions. The average temperature in Alamosa, which is situated at an elevation of $7,541 \mathrm{ft}(2,298 \mathrm{~m})$, for January, the coldest month of the year, is $34.7^{\circ} \mathrm{F}$ during the day and $-1.8^{\circ} \mathrm{F}$ in the evening, while Wolf Pass, which is located at an elevation of 10,640 $\mathrm{ft}(3,243 \mathrm{~m})$, averages $33.4^{\circ} \mathrm{F}$ during the day and $10.2^{\circ} \mathrm{F}$ at night. The average temperature in Alamosa in July, the warmest month of the year, is $82^{\circ} \mathrm{F}$ during the day and $47^{\circ} \mathrm{F}$ at night while Wolf Creek Pass averages $72.7^{\circ} \mathrm{F}$ during the day and $44.6^{\circ} \mathrm{F}$ at night. Further south, the average temperature in Taos, New Mexico, located at an elevation 6,969 ft (2,124 m), for January, is $40^{\circ} \mathrm{F}$ during the day and $11^{\circ} \mathrm{F}$ at night. In July, temperatures range from $85^{\circ} \mathrm{F}$ during the day to $52^{\circ} \mathrm{F}$ at night. In Espanola, average January temperatures range from $47^{\circ} \mathrm{F}$ during the day to $15^{\circ} \mathrm{F}$ at night, while July temperatures range from $90^{\circ} \mathrm{F}$ during the day to $57^{\circ} \mathrm{F}$ at night (U.S. Climate Data 2016a, b). Precipitation in the San Luis Valley - Taos Plateau averages 6 to 12 inches a year while the surrounding mountains may receive an average of 24 to 42 inches a year depending on elevation (U.S. Climate Data 2016a, b).

In Colorado Prehistory: A Context for the Rio Grande Basin (Martorano et al. 1999), M. Jodry and M. Martorano provide a comprehensive discussion of the current knowledge of Paleoindian and Post-Paleoindian paleoenvironmental studies and the reader is referred to that volume for more detail regarding knowledge of climate and how climatic conditions affect the valley.

\subsection{Culture History}

Humans have occupied the San Luis Valley - Taos Plateau for approximately 12,000 years. The interactions of Native Americans, Spanish, Mexican, and Euro-Americans with the land are complex and varied. The following summary of the prehistory and history of the study area is brief and meant to put the themes of the cultural heritage values and risk assessment into context. A number of publications give a detailed discussion of the prehistory and history of the San Luis Valley - Taos Plateau and the reader is directed to those publications for further information (Simmons 1999; White 2005; Higgins et al. 2013; Martorano et al. 1999; Guthrie et al. 1984; Carter and Mehls 1984; Church et al. 2007; SdCNHA 2013; NRGNHA 2013).

Although a number of archaeological studies have been conducted in the study area, less than $8 \%$ of the study area has been surveyed or investigated. Large areas of the study area are on private land and few formal investigations have taken place in these areas. As a result, the understanding of the prehistory of the study area is limited. The majority of the information regarding the Paleoindian, Archaic, and Late Prehistoric/Puebloan Periods is based on material presented in Martorano et al. (1999) unless otherwise noted. 


\subsubsection{Paleoindian ( 12,000 to 7,500 B.P.)}

The San Luis Valley has the highest density of Paleoindian finds in Colorado. Current archaeological evidence indicates that Paleoindians migrated to the San Luis Valley - Taos Plateau area around 12,000 years ago. Characteristic Paleoindian site markers are elongated, lanceolate, and sometimes fluted spear points found in isolation or in conjunction with large game kill and processing sites and temporary camps (USFWS 2012). Projectile points from the Clovis, Folsom, and Plano periods have been found in the valley. These early inhabitants led a nomadic lifestyle that relied heavily on the hunting of large mammals that are now extinct, such as ancient bison and mammoths while supplementing with other foodstuffs such as plants, small game, birds, eggs, fish, and insects. Paleoindian sites within the study area are clustered around wetlands and the shorelines of ancient lakes of the valley and in the foothills of the San Juan Mountains. Larger sites like Stewart's Cattle Guard Site, the Linger Folsom Site, Zapata Folsom Site, and the Reddin Site are concentrated in the central and eastern part of the study area, while lithic scatters and isolated finds are found throughout. Artifact assemblages suggest a variety of activity in the valley from animal procurement and work camps to domestic activity such as camping and cooking. Seasonal use of high-altitude sites is evidenced by the artifact assemblage found at the Black Mountain Site near North Clear Creek in the San Juan Mountains, which suggests animal processing, tool processing, and domestic activities. These early people likely followed the seasonal circuit of large game - travelling to the grazing areas in the mountain meadows in the summer and returning to lower elevations in the fall. Artifacts found on the eastern side of the study area suggest early inhabitants had a strong connection to the southern and eastern plains.

\subsubsection{Archaic ( 7,500 B.P -1500 B.P.)}

The Archaic period is characterized by a shift from elongated lanceolate projectile points to stemmed and notched points; an increase in ground-stone tools; the use of a larger variety of plants and animals; the introduction of cordage, basketry, and cloth; and the appearance of rock art. Archaic Period lithic scatters, open camps, rock art, and architectural features have been found throughout the study area with a large cluster of open camps occurring around the seasonal lakes (Dry, San Luis, Russell, and Mishak Lakes) in the northern portion of the valley. Early Archaic (7,500 to 5,000 years B.P.) sites are present in the San Luis Valley; with many located near the Rio Grande (Guthrie et al. 1984). Continued use of the valley is documented by Middle Archaic (5,000 to 3,000 years B.P.) sites in Saguache County and in the northern portion of the valley. Late Archaic Period (3,000 to 1,500 years B.P.) sites have been recorded throughout the valley as indicated in results from a surface survey of the Blanca Wildlife Refuge (Dick 1975, as cited in Guthrie et al. 1984), a 1980 closed basin survey of a conveyance channel in Alamosa and Saguache Counties (Button 1980), and, in Conejos County, a survey of the La Jara Reservoir area (west of the Los Mogotes SEZ) for the Baca Land Exchange (Wells 2008).

It is unclear based on the archaeological evidence when the Archaic Period classification should end as the lifestyle appears to continue throughout the Late Prehistoric Period. The artifacts found at these sites suggest a continued and perhaps increased dependence on the valley's lacustrine and wetland resources, although this may be the result of the location of archaeological investigations rather than a reflection of the inhabitants of the valley. 
Archaeological investigations are also lacking in the Taos Plateau and the extent to which the Taos Plateau was used during this stage is largely unknown. However, evidence from just west of the Taos Plateau indicates that at the end of the Archaic Period, ancient southwestern peoples began to supplement their diet by growing corn, bean, and squash, in addition to hunting and gathering wild plants (NRGNHA 2013).

\subsubsection{Late Prehistoric/Puebloan ( 1,500 B.P - 700 B.P)}

The Late Prehistoric Period is largely defined by the introduction of ceramic technology and small side-notched projectile points developed for use in the newly introduced bow and arrow, coupled with a larger population and more sedentary lifestyle. Little chronological data exists within the study area for this stage and a date of transition between the Archaic and Late Prehistoric in the San Luis Valley is difficult to determine; however, Martorano et al. (1999) provides an arbitrary date of $~ 1,500$ B.P. for the beginning of the Late Prehistoric Period. Late Prehistoric site types in the study area include lithic scatters, open camps, ceramic scatters, quarries, architectural features, rock shelters, rock art, and burials. The largest number of Late Prehistoric sites are clustered around San Luis Lakes, San Luis Creek, and Lower Saguache Creek on the east side of the valley and near del Norte on the west side of the valley, suggesting continued use of lacustrine and wetland resources, although, again, this may be the result of the location of archaeological investigations rather than a preference of the inhabitants of the valley.

Further south, on the Taos Plateau, nearly 300 ancestral Puebloan archaeological sites have been recorded in the vicinity of Taos. Puebloan villages ranged in size and typically had a central space consisting of a plaza, multiple rooms, and kivas. Taos and Picuris Pueblos are located within the project area (NRGNHA 2013).

\subsubsection{Ethnohistoric Background}

This section is a very brief summary of the ethnohistoric relationships of Native American tribes with present day affiliations to the San Luis Valley - Taos Plateau and provides a context for those tribes that have expressed an interest in the study area and for their connection to the valley and relationship with the landscape. David White (2005), in Seinanyédi: An Ethnographic Overview of the Great Sand Dunes National Park and Preserve, presents a brief historic and cultural sketch of the 36 present-day tribes with historic affiliations to the study area along with more detailed history and ethnography on the Jicarilla Apache, Navajo (Diné), Ute, Tewa and Tiwa. In Cultural Continuity: An Ethnographic Study Related to Potential Solar Energy Development in the San Luis Valley, Colorado, Higgins et al. (2013) provides information on tribal connections to the study area, places of importance, and views on potential solar development within the San Luis Valley. Readers are encouraged to review these volumes for a more comprehensive understanding of the historical-cultural dynamics of the early inhabitants and users of the San Luis Valley - Taos Plateau. A concise summary of the ethnohistory of the region was prepared by Argonne in the Solar Programmatic Environmental Impact Statement (BLM and DOE 2010 and 2012) and much of that text that has been brought forward in this section. 
At least 36 tribes have some kind of direct or indirect historic affiliation with the San Luis Valley - Taos Plateau study area (see White 2005). According to White, Native American tribes with historically documented, direct, and continuing affiliations with the study area and whose oral histories include places in the study area are the Jicarilla Apache, Navajo, and Ute. The oral histories of the Tiwa (Taos and Picuris) and Tewa (Ohkay Ohwingeh, Santa Clara, Nambe, San Ildefonso, Pojoaque, and Tesuque) Pueblos refer to places within the valley. These tribes, along with the Hopi, Zuni, Comanche, and Kiowa also have a documented use of the valley, but to a lesser degree.

The traditional territories of the Jicarilla Apache, Ute, and Navajo all intersect on the San Luis Valley - Taos Plateau. All three groups utilized the landscape as nomadic huntergatherers exploiting lithic resources and plant collection sites, hunting game, and trading with the Pueblos to the south. The Jicarilla Apache and Navajo, influenced by their Puebloan neighbors, also incorporated agriculture growing corn, beans, maize, melons and squash. There are many resource collection areas and sacred places within the study area that are important to the contemporary Native American tribes listed above.

\section{Ute}

The Ute ranged from Utah's Oquirrh Mountains in the west to the Front Range in Colorado in the east (Callaway et al. 1986). Those who ranged primarily in Colorado are often classified as eastern Ute. Prior to their enforced settlement on reservations, the Ute led a mobile lifestyle. Groups centered on nuclear families followed a seasonal round, hunting and gathering in the various habitats that their range provided them as resources became available throughout the year. Family groups would join one another or hunt and gather separately depending on the abundance of the resource sought. They were loosely organized into regional groups or bands, whose composition continually fluctuated. These groups tended to prefer the upper basins of river drainages, which provided access to a wider range of resources. The Capote band was resident in the San Luis Valley as early as the eighteenth century, while their eastern neighbors, the Moache, are likely to have exploited the resources of the valley as well (Baker et al. 2007). In general, hunting grounds were open to all Ute groups, although etiquette demanded that local groups be consulted before hunting or gathering in their territory. Typical Ute dwellings were conical wickiups constructed of wooden poles. Camps also included brush structures and ramadas (Callaway et al. 1986); however, wickiups recorded in the San Luis Valley are scarce, suggesting an early change there to the tepee (Baker et al. 2007); however, an alternate explanation may be that wickiups have been more rarely found in the San Luis Valley forests because of prior impacts from multiple use, past fires, and wood cutting.

Beyond hunting and gathering, the Ute had trading and raiding relationships with neighboring tribes, including the Pueblos to the south, supplying them with buckskin. With the arrival of the Spanish in New Mexico, this relationship was easily extended to them. Located at the southern extent of the Ute range, the Capote would have been among the first Utes to encounter Spanish colonists and explorers. By 1765 when Juan Rivera made the first recorded exploration into Ute heartland, the Ute were already engaged in down-the-line trade for Spanish goods, both from New Mexico and via Plains tribes from Mexico itself. Between their mobile 
lifestyle and trading expeditions, a network of foot trails extended throughout Ute territory and beyond (Baker et al. 2007).

A Ute reservation was established in northeastern Utah in 1861, and much of western Colorado was included in a second reservation in 1868. There were significant reductions in the Colorado reservation in 1874 and 1880 when most Utes were required to move to the reservation in northeastern Utah. The last remnants of the Colorado reservation are the Southern Ute and Ute Mountain Ute reservations in southwestern Colorado. The descendants of the Moache and Capote Bands are located on the Southern Ute Reservation (Callaway et al. 1986; Simmons 2000).

\section{Jicarilla Apache}

Primarily hunters and gatherers, the traditional range of the Jicarilla Apache included northeastern New Mexico as far south as modern Mora and as far north as the Arkansas River in Colorado. While their hunting activities extended well into the plains east of the Rockies, their home ranges and base camps were in the mountains of northern New Mexico (Opler 1936). Their loosely organized matrilineal groups may be divided into two bands: the Olleros, or potters, ranged west of the Rio Grande and the Llanos, or plainsmen, to the east. The hunting and gathering range of each group included parts the San Luis Valley (Tiller 1983). Poised between the Plains and Pueblo cultures, they were influenced by each, while retaining an Apachean cultural foundation with mythology and ritual similar to that of the Navajo. The Ollero groups, the only groups to produce pottery, were more likely to include agriculture in their substance base and lived in flat-roofed rancherias, whereas the Llano groups relied less on horticulture and adopted the horse, tepee, and travois while on the plains and domed brush-covered structures when in the mountains. Like other Apaches, they traditionally saw the natural world as suffused with supernatural power. Natural features and phenomena are seen as expressions of that power. Individuals could receive power from animals, natural phenomena, or celestial bodies. Prominent physical features could be places of power and supernatural instruction (Opler 1936; Tiller 1983).

In 1887 a reservation was established somewhat east of their traditional range straddling the continental divide in the mountains of northern New Mexico. Little of this land was suitable for agriculture, and most agricultural lands and water rights that existed had already been taken by homesteaders. Initial attempts at raising sheep were enhanced by the addition of lower elevation lands in 1907 for winter pasturing. Raising sheep aided tribal finances, and the Jicarilla were able to organize in 1937 under the Indian Reorganization Act. In the 1950s, revenues from gas and oil resources on tribal lands began to supplement revenue from livestock. Increasingly the Jicarilla population congregated at Dulce, New Mexico, the center of tribal government, and emphasis shifted from stock raising to wage labor. By the 1960s, reliance on traditional gathering activities was limited. Identification with the former bands was diminished, replaced by identification with the tribe as a whole (Tiller 1983). 


\section{Navajo}

The traditional Navajo homeland, or Dinétah, is bounded by four sacred mountains: Sis Naajinii (Blanca Peak, located on the east side of the San Luis Valley) on the east; Tsoo Dzil (Mount Taylor near Grants, New Mexico) on the south; Dook'o'’oosliid (San Francisco Peaks near Flagstaff, Arizona) on the west; and Dibé Ntsaa (La Plata Mountains near Durango, Colorado) on the north. Traditional use areas extend well beyond this boundary (Bureau of Reclamation 1995). Ethnohistoric accounts, as well as archaeological and linguistic evidence suggest that the Apacheans (Athabaskan-speaking ancestors of the Navajos and Apaches) entered the North American Southwest sometime between A.D. 1000 and the 1600s. During this time, the Apacheans traded and intermarried with neighboring groups, resulting in the traditional Navajo culture of today (Brugge 1983, Brown 1991). The Navajo, however, contend they have always lived "among the four sacred mountains" having emerged from the four underworlds into this world at Mount Blanca (Blanca Peak) (Two Bears 2012).

The Navajo were present in the San Luis Valley at the time of Spanish contact and territorial, spiritual and ceremonial connections with the valley likely existed long before that. Primarily hunter-gathers, the Navajo lived in family groups and loosely knit bands, following the seasonal round. Navajo dwellings consisted of hogans, with early hogans constructed in a conical-shape with interlocking poles transitioning later to an earth-covered, dome-shaped roof with side walls of logs or stones. The easternmost part of their hunting and gathering grounds extended into the San Luis Valley. The Navajo had contact with Pueblo communities and the two groups likely influenced each other. The Navajo were early to adopt agriculture, growing Puebloan crops such as corns, beans, squash, pumpkins, and melons and later adopting Spanish crops such as wheat, barley, oats, and peaches, and they likely procured ceramics and cloth from the Pueblo people (Brugge 1983, Brown 1991).

\section{Pueblos}

Many other Native American tribes have associations with the San Luis Valley - Taos Plateau. The origin story of the people of the Picuris Pueblo suggests an emergence into this world via a lake. In some versions of the story, the location of the lake is located in the mountains north of Alamosa, Colorado.

The origin story of the Taos Pueblo also suggests an emergence from a lake, but a lake within the San Luis Valley. The Pueblos relied heavily on agriculture but did supplement their diet with resources found throughout the study area. The people of Taos were known to use the area for bird hunting while the people of Picuris were known to hunt buffalo.

The Zuni are ostensibly connected to the San Luis Valley through their use of King Turquoise Mine, which may be the mine from which Turquoise Old Man and Salt Old Woman brought stones to start the Zuni mine at Cerrillos, New Mexico. The Hopi may have affiliations with the San Luis Valley as their ancestry is very mixed and some clans are Tewa and Tiwa in origin. 


\section{Plains Tribes}

The Kiowa and Comanche played important roles as enemies and allies of the Utes, Jicarilla Apache, and Spanish during the $18^{\text {th }}$ and 19 th centuries.

\section{Alliances among Tribes and Europeans}

First contact between the Native Americans of the San Luis Valley - Taos Plateau and the Spanish occurred in the late $16^{\text {th }}$ century-early $17^{\text {th }}$ century. Initially, Native American groups essentially practiced their traditional life ways while sporadically interacting with Spanish, French, Mexican, and Euro-American groups as they traversed the San Luis Valley - Taos Plateau. Initially, interactions were usually friendly, but as Europeans pushed further into the valley changes to traditional Native American life ways occurred through frequent interaction, hostilities, trade, and intermarriage. European goods such as glass, metal, guns, and horses permeated Native American culture. The Navajo were introduced to pastoralism and began to keep sheep, cattle, goats, and chickens. Horses were traded or captured during raids. With the acquisition of horses, Native Americans were able to travel further and longer and carry more items, increasing contact and trade with other tribes, intensifying inter-tribal and tribal-European raids and intensifying the slave trade.

Alliances between Native American tribes and the Europeans were constantly changing, in part driven by pressures from competing settlers and in part by the ongoing slave trade that was developed to work mines in the area. The Navajo frequently raided Taos and Isleta Pueblos and other tribes for resources, including slaves. The Utes were also heavily involved in the slave trade in which the Ute kidnapped women and children from the pueblos and sold them to the Spanish, French, and Mormons. The Jicarilla Apache and Picuris were strong allies and Picuris and Taos Pueblo were closely allied at the time of the Pueblo Revolt in 1680. The Jicarilla Apache wintered at the pueblo and often traded and hunted game with the Picuris. The Picuris were also in good relations with the Ohkay Owingeh. In the 1690s the Picuris fled their pueblo during the Spanish Reconquest. Picuris people, and possibly people from Santa Clara Pueblo and Ohkay Ohwingeh, fled north, along the Picuris Trail to shelter with the Jicarilla Apache. The Utes entered the plains in the early $18^{\text {th }}$ century eventually forming an alliance with the Comanche against the Jicarilla Apache and Spanish settlements. The Jicarilla Apache, in turn, formed an alliance with the Spanish in which the Jicarilla Apache helped keep the Comanche and Ute from attacking Spanish settlements. By the mid- $18^{\text {th }}$ century, the Navajo were spread throughout the valley, but were eventually forced back west by the Utes and Comanche. The alliance between the Comanche and Ute ended in 1747 after the Utes were blamed for a Spanish raid that was committed by the Comanche. From the late 1740s to the 1760s, the Comanche served as trade intermediaries between the Spanish and French in Taos, but occasionally raided settlements in New Mexico. Initially enemies, the Kiowa and Comanche became allies in the late $18^{\text {th }}$ century, fighting against the Jicarilla Apache, Utes and Spanish. Shortly thereafter, the Ute and Jicarilla Apache formed an alliance and continued to mutually reside in the valley throughout the rest of the $18^{\text {th }}$ to the mid- $19^{\text {th }}$ century, defending their territory from the Kiowa and Comanche who continued to press into the valley from the east. The Kiowa were eventually defeated in 1847 by the Ute in a battle at what is now known as Kiowa Hill. The Ute and Navajo were also allies during the $18^{\text {th }}$ century. The U.S. takeover of New Mexico in 1849 led to 
increased hostility and conflict between the Americans and the Utes, as well as other tribes who still resided in the valley.

\subsubsection{Historic Background}

This section briefly summarizes the historic themes within the San Luis Valley between the times of early contact with Native Americans to the mid- $20^{\text {th }}$ century.

\subsubsection{Spanish Exploration}

Spanish excursions into the study area mainly consisted of expeditions in search of precious metals, overland routes to California, rumored cities of wealth and campaigns against Native Americans. The period of Spanish exploration within the study area may have begun as early as 1540-1542, when Francisco de Coronado's search for the fabled "Seven Cities of Cibola” led him through the lower San Luis Valley - Taos Plateau. A member of his army is credited with 'discovering' Taos Pueblo which would prove to be an integral part of SpanishNative American relations in the valley (Rael y Ortega and Cuddihy 2003). In 1583, Antonio de Espejo named the Rio del Norte after crossing it twice on an expedition in search of two friars conducting missionary work. His journey took him to the Pueblos of Zia, Acoma, Zuni and Hopi (Blake 2010; White 2005). In 1598, Don Juan de Oñate declared all of the territory drained by the Rio Grande for the Spanish Empire, although it is believed that his expedition didn't travel any farther north than Taos (Rael y Ortega and Cuddihy 2003).

For the next 100 years, the Spanish continued their efforts to retain control of this territory, conquering pueblos, conscripting Native Americans to work in the mines, attempting to convert Native Americans to Catholicism, and sending minor expeditions to explore the San Luis Valley - Taos Plateau. In the mid-17th century, the Spanish established the colony of New Mexico in the Pueblo territory of the Rio Grande. The Spanish continued to capture Native Americans thought hostile, leading to an active slave trade in the region. In 1680, most of the pueblos in New Mexico revolted, driving the Spanish from the area and halting Spanish exploration for a number of years (Higgins et al. 2013; White 2005; Rael y Ortega and Cuddihy 2003; Carter and Mehls 1984). In 1691, Don Diego de Vargas arrived in El Paso intent on reclaiming New Mexico for the Spanish. He reestablished Spanish claim by 1692, although intense conflict continued between the Spanish and the Native Americans (White 2005; Rael y Ortega and Cuddihy 2003).

The first notable expedition into the San Luis Valley - Taos Plateau after the revolt was in 1694, when de Vargas's six-day journey to investigate Ute activity took him from Santa Fe, into the San Luis Valley - Taos Plateau and as far north as the confluence of Culebra Creek and the Rio Grande before he headed back to Santa Fe. On this journey, he raided the Taos and Picuris Pueblos for food and supplies and formed temporary alliances with the Ute and Apaches against the Comanche (White 2005, Higgins et al. 2013).

Over the next 85 years the valley saw the occasional expedition in search of precious metals and overland routes to California. Mid-18 $8^{\text {th }}$ century excursions into the valley included Juan de Rivera's search for gold and silver in 1761 and the expedition of Frays Silvestre Velez 
de Escalante and Antanasio Dominguez whose search for a route from Santa Fe to the California Missions in 1776 would eventually be established as the Old Spanish Trail. In 1779, Juan Bautista de Anza travelled through the valley in an effort to suppress Comanche raids on Spanish settlements. He met with Ute and Apache warriors at the Conejos River and continued up the north branch of the Spanish Trail, along the foothills of the San Juan Mountains, through Poncha Pass, and on into the plains, where they eventually caught up with the Comanches and killed the Comanche Chief, Cuerno Verde, before crossing back into the valley at Sangre de Cristo Pass and continuing home to Santa Fe (White 2005, Higgins et al. 2013).

\subsubsection{American Exploration}

Early American explorations of the San Luis Valley - Taos Plateau were mostly expeditions to map uncharted territory and potential central overland routes to the Pacific Ocean. One of the first American explorers to enter the San Luis Valley was Lieutenant Zebulon Montgomery Pike, in 1807. Pike and his men, charged with mapping the western portions of the Louisiana Purchase and the source of the Red River, entered the San Luis Valley near the Great Sand Dunes. They built a small stockade near the Conejos River, near present-day Sanford, where they stayed for about one month before Spanish officials took Pike to Santa Fe for questioning (Simmons 1999). A replica of Pike's Stockade now stands in what is believed to be the original location of the site and is a National Historic Landmark (Mendinghall 1978).

In 1848 and 1853 John C. Fremont, whose early expeditions to California and Oregon plotted the first reliable map of the West, was sent to New Mexico in search of a central railroad route to the Pacific. Both of Fremont's expeditions through the valley ended in the San Juan Mountains, where he and his men suffered through starvation, frozen hands and feet, and the death of many individuals. Evidence of these journeys has been found at two locations in the San Juan Mountains, a campsite at Wannamaker Creek and another at the head of Embargo Creek (Simmons 1999; Carter and Mehls 1984).

In 1853, John Williams Gunnison led an expedition to survey for a central railroad route through the Rocky Mountains to the headwaters of the Rio Grande. Gunnison and his men entered the San Luis Valley through Sangre de Cristo Pass and continued through the northern end of the San Luis Valley and on to Utah, where Gunnison and other members of his party were attacked and killed by Native Americans. Gunnison's expedition failed to find a suitable path for the central route, but the path he traced was later used for the Denver and Rio Grande Rail Line from Denver to Salt Lake City and his expedition mapped the San Luis Valley and Cochetopa Pass for the first time (Simmons 1999; Mehls and Carter 1984).

\subsubsection{American Military Conflict}

During the latter half of the $19^{\text {th }}$ century, hostilities between emigrants and Native Americans grew as American explorers and settlers began moving into the San Luis Valley Taos Plateau. During this time, military posts provided protection to settlers. Fort Massachusetts, the first military post in Southern Colorado, was built in 1852, several miles off the Sangre de Cristo Pass trail. Because of its poor location, the fort was abandoned in 1858 and a new post, Fort Garland, was built six miles south. Fort Garland was abandoned in 1883 and soldiers were 
relocated to Fort Lewis, west of the San Juan Mountains. Men from Fort Garland served in the only Civil War battle to take place in the West, at Glorietta Pass, to drive back Texas confederates. Buffalo Soldiers, African-American soldiers named as such by the Cheyenne, also served at Fort Garland between 1876 and 1879. Both Fort Massachusetts and Fort Garland were important stopping places for surveyors, and soldiers stationed here participated in many campaigns against the Utes and Apaches as well as rescue missions throughout the mountains (Simmons 1999; Carter and Mehls 1984). Both Fort Garland and Fort Massachusetts are listed on the National Register of Historic Places. At Fort Garland, 6 of the original 14 adobe buildings now serve as a museum (Fink 1970), which hosts reenactments and cultural activities throughout the year (San Luis Valley Museum Association 2014).

Farther south, Fort Burgwin was constructed approximately ten miles south of Taos in 1852. After the Battle of Cieneguilla, it became headquarters for retaliation against the Jicarilla Apache and troops frequently organized there before following Indian trails through the San Luis Valley and into the surrounding mountains. Fort Burgwin was abandoned in 1860 and soldiers were relocated to Fort Union or Fort Garland (Murphy 1973). Fort Burgwin now serves as a satellite campus for Southern Methodist University in Taos (SMU in Taos 2014).

\subsubsection{Spanish and Mexican Land Grants}

From 1693 to 1846 the Spanish government, and later the Mexican government, established large tracts of land in New Mexico for use by settlers. The purpose of these grants was three-fold: to encourage settlement, reward supporters of the Spanish government and to create a buffer zone between Native American tribes and Spanish and Mexican settlers (GAO 2001). Land grants were made to individuals, groups, and communities. It was on the Conejos and Sangre de Cristo Land Grants that the first permanent settlements were founded in the San Luis Valley - Taos Plateau. Spain also extended land grants to a number of Pueblos in New Mexico, including the Picuris, Taos, Ohkay Owingeh (San Juan), Santa Clara, Nambe, San Ildefonso, Pojoaque, and Tesuque (Sayles and Williams n.d.; Center for Land Grant Studies 2005).

The Mexican-American War ended with the Treaty of Guadalupe Hidalgo, in which the United States agreed to recognize ownership of all property within its newly acquired territories. In 1854, Congress established the Office of Surveyor General of New Mexico to examine land grant claims. The Surveyor reviewed land grant documentation and made a recommendation to the Secretary of the Interior as to whether a grant should be rejected or confirmed. If the surveyor confirmed the grant, he would recommend that Congress do so as well, but congressional review ended in the 1870s. In 1891, Congress established the Court of Private Claims to review the remaining claims that had been reviewed by the Surveyor but had not been approved by Congress. In 1897, United States v. Sandoval et al., 167 U.S. 278, the court established that all title to common lands in community land grants were in fact property of Mexico, not the grantees, and therefore, those lands were ceded to the United States at the end of the war. This decision did not overturn previous land grant confirmation, but did affect all claims adjudicated by the Court of Private Claims. Whether or not the United States honored its treaty obligations remains a controversial issue (GAO 2001). 
While many of the land grants in the study area were adjudicated, many more were reduced in acreage during their confirmation, and some were completely rejected by Congress or the Court of Private Claims. The Conejos Land Grant fell into the latter category. In 1861, the grantees of the Conejos Land Grant made an application for confirmation to the Surveyor Generals Office. In lieu of the missing 1833 document in which the land was awarded, the grantees submitted sworn testimony from officials who were involved in the granting of the possession in 1842, but paperwork regarding the grant was delayed and it appears the issue was almost forgotten by the Surveyors office. It wasn't until 1890 that Cresencio Valdez, son of a colonizer, again petitioned for the grant to be confirmed. The case wasn't heard in the Court of Private Claims until 1900 and was eventually rejected on the basis of the missing 1833 document as well as testimony from the Governor of New Mexico who expressed doubt in his authority to grant possession (Simmons 1999).

The Sangre de Cristo Land Grant was adjudicated in full and, for roughly 100 years, descendants of the original settlers had access to a common area in the Sangre de Cristo Mountains that made it possible for small farmers and herders to survive economically (SdCNHA 2013). This common area is generally referred to as Taylor Ranch, a 79,500 acre tract of land within the Sangre de Cristo Land Grant purchased in 1960 by Jack Taylor, a North Carolina lumberman. Although the purchase agreement indicated that Taylor would allow the local people their use rights of pasture, wood and lumber, he fenced off the property shortly after its purchase, denying access. In 1981, landowners who are successors to the original settlers on the Sangre de Cristo grant filed suit, claiming that they had access and use rights to graze livestock, gather firewood and timber, hunt, fish and recreate on Taylor Ranch and that Taylor denied those rights when he installed the fence. Initially, the court ruled that the landowners have no legally enforceable rights because the landowners had not proved their rights and Colorado law did not recognize implied rights. This ruling was upheld in the court of appeals. In 2002 in Eugene Lobato vs. Zachary Taylor, the Colorado Supreme Court reversed the ruling, holding that the landowners have rights of access for grazing, firewood, and timber, but not for fishing, hunting, and recreation (Colorado Supreme Court 2002; Golten 2005). For a more detailed discussion of this landmark case the reader is directed to Golten 2005 and Lobato v. Taylor (Colorado Supreme Court 2002).

A list of land grants within the study area is presented in Table 2-3 and a definition of land grant types, is provided in Table 2-4 (adapted from Sayles and Williams n.d.; Center for Land Grant Studies 2005). Figure 2-2 shows the location of land grants relevant to the study area. 
Table 2-3. Land Grants within the San Luis Valley - Taos Plateau Study Area (after Center for Land Grant Studies 2005)

\begin{tabular}{|c|c|c|c|c|c|}
\hline Grant & $\begin{array}{l}\text { Location (within study area } \\
\text { unless otherwise indicated) }\end{array}$ & Year Granted & Type of Grant & Grantee & Comments \\
\hline (Los) Conejos & $\begin{array}{l}\text { Alamosa, Rio Grande, Mineral \& } \\
\text { Conejos Co., Colorado and Rio } \\
\text { Arriba and Taos Co., New Mexico }\end{array}$ & 1842 & Community & Mexican & Not adjudicated \\
\hline (Town of ) Chamita & Rio Arriba Co., New Mexico & 1724 & Community & Spanish & \\
\hline (Town of) Abiquiu & $\begin{array}{l}\text { Rio Arriba Co., New Mexico (West } \\
\text { of study area) }\end{array}$ & 1754 & $\begin{array}{l}\text { Pueblo-Genizaro } \\
\text { Community }\end{array}$ & Spanish & \\
\hline Antoine Leroux & Taos Co., New Mexico & 1742 & Quasi-Community & Spanish & \\
\hline Antonio de Abeyta & Rio Arriba Co., New Mexico & $1736^{1} 1809^{2}$ & Private & Spanish & $\begin{array}{l}{ }^{1} \text { Sayles and } \\
\text { Williams, n.d. } \\
{ }^{2} \text { Center for } \\
\text { Land Grant } \\
\text { Studies } 2005 \\
\end{array}$ \\
\hline $\begin{array}{l}\text { Antonio Martinez or } \\
\text { Lucero Godoy (Lucero de } \\
\text { Godoi) }\end{array}$ & Taos Co., New Mexico & 1716 & Quasi-Community & Spanish & \\
\hline Arroyo Hondo & Taos, Co., New Mexico & 1815 & Community & Spanish & \\
\hline Baca No. 1 & $\begin{array}{l}\text { Rio Arriba and Sandoval Co., New } \\
\text { Mexico (Adjacent to and SW of } \\
\text { study area) }\end{array}$ & 1860 & Private & Spanish & \\
\hline Bartolome Sanchez & Rio Arriba Co., New Mexico & 1707 & Private & Spanish & \\
\hline $\begin{array}{l}\text { Beaubien and Miranda } \\
\text { (Maxwell) }\end{array}$ & $\begin{array}{l}\text { Colfax and Taos, Co., New Mexico } \\
\text { and Las Animas Co., Colorado } \\
\text { (East of study area) }\end{array}$ & 1841 & Private & Mexican & \\
\hline
\end{tabular}


Table 2-3. (Cont.)

\begin{tabular}{|c|c|c|c|c|c|}
\hline Grant & $\begin{array}{l}\text { Location (within study area } \\
\text { unless otherwise indicated) }\end{array}$ & Year Granted & Type of Grant & Grantee & Comments \\
\hline $\begin{array}{l}\text { Black Mesa (Diego de } \\
\text { Medina) }\end{array}$ & Rio Arriba Co., New Mexico & 1743 & Private & Spanish & \\
\hline $\begin{array}{l}\text { Canada de Santa Clara } \\
\text { (Pueblo of Santa Clara }\end{array}$ & $\begin{array}{l}\text { Santa Fé, Rio Arriba, Los Alamos } \\
\& \text { Sandoval Co., New Mexico } \\
\text { (Adjacent to and South of study } \\
\text { area) }\end{array}$ & 1763 & Pueblo Protective & Spanish & \\
\hline $\begin{array}{l}\text { Canon de Chama (San } \\
\text { Joaquin del Rio de Chama) }\end{array}$ & $\begin{array}{l}\text { Rio Arriba and Sandoval Co., New } \\
\text { Mexico }\end{array}$ & 1806 & Community & Spanish & \\
\hline Cristoval de la Serna & Taos Co., New Mexico & 1710 & Quasi-Community & Spanish & \\
\hline Francisco Montes Vigil & Rio Arriba Co., New Mexico & 1754 & Private & Spanish & \\
\hline Gijosa (Rancho de Taos) & Taos Co., New Mexico & 1715 & Quasi-Community & Spanish & \\
\hline $\begin{array}{l}\text { Ignacio de Roybal (Town } \\
\text { of Jacona) }\end{array}$ & $\begin{array}{l}\text { Santa Fe Co., New Mexico (South } \\
\text { of study area) }\end{array}$ & 1702 & Quasi-Community & Spanish & \\
\hline $\begin{array}{l}\text { Juan Batista Valdez } \\
\text { (Canon de Perdernales) }\end{array}$ & $\begin{array}{l}\text { Rio Arriba Co., New Mexico (SW } \\
\text { of study area) }\end{array}$ & 1807 & Quasi-Community & Spanish & \\
\hline Juan Jose Lobato & Rio Arriba Co., New Mexico & $1894^{1,2} 1740^{3}$ & Quasi-Community & Spanish & $\begin{array}{l}{ }^{1} \text { Sayles and } \\
\text { Williams, n.d. } \\
{ }^{2} \text { GAO } 2001 \\
{ }^{3} \text { Center for } \\
\text { Land Grant } \\
\text { Studies } 2005\end{array}$ \\
\hline La Polvadera & $\begin{array}{l}\text { Rio Arriba Co., New Mexico } \\
\text { (Adjacent to and West of study } \\
\text { area) }\end{array}$ & 1766 & Quasi-community & Spanish & \\
\hline Las Trampas & $\begin{array}{l}\text { Taos and Rio Arriba, Co., New } \\
\text { Mexico }\end{array}$ & 1751 & Community & Spanish & \\
\hline
\end{tabular}


Table 2-3. (Cont.)

\begin{tabular}{|c|c|c|c|c|c|}
\hline Grant & $\begin{array}{l}\text { Location (within study area } \\
\text { unless otherwise indicated) }\end{array}$ & Year Granted & Type of Grant & Grantee & Comments \\
\hline Luis Maria Baca No. 4 & Saguache, Co., Colorado & 1862 & Congressional & Mexican & \\
\hline Mora (Town of) & $\begin{array}{l}\text { Mora, San Miguel, Colfac, and } \\
\text { Taos Co., New Mexico (SE of study } \\
\text { area) }\end{array}$ & 1835 & Community & Mexican & \\
\hline Nambe Pueblo & $\begin{array}{l}\text { Santa Fe Co., New Mexico } \\
\text { (adjacent to and South of study } \\
\text { area) }\end{array}$ & $\begin{array}{l}1856 \text { (date } \\
\text { confirmed) }\end{array}$ & Pueblo Community & Spanish & \\
\hline $\begin{array}{l}\text { Nuestra Senora del } \\
\text { Rosario San Fernando y } \\
\text { Santiago }\end{array}$ & Rio Arriba Co., New Mexico & 1754 & Community & Spanish & \\
\hline Ojo Caliente & $\begin{array}{l}\text { Rio Arriba and Taos, Co., New } \\
\text { Mexico }\end{array}$ & 1793 & Community & Spanish & \\
\hline Picuris Pueblo & Taos Co., New Mexico & 1689 & Pueblo Cruzate & Spanish & \\
\hline $\begin{array}{l}\text { Piedra Lumbre (Casas de } \\
\text { Riano) }\end{array}$ & $\begin{array}{l}\text { Rio Arriba Co., New Mexico (West } \\
\text { of study area) }\end{array}$ & 1766 & Private & Spanish & \\
\hline Plaza Blanca & $\begin{array}{l}\text { Rio Arriba Co., New Mexico (West } \\
\text { of study area) }\end{array}$ & 1739 & Private & Spanish & \\
\hline Plaza Colorado & $\begin{array}{l}\text { Rio Arriba Co., New Mexico } \\
\text { (West of study area) }\end{array}$ & 1739 & Private & Spanish & \\
\hline Pojoaque Pueblo & $\begin{array}{l}\text { Santa Fe Co., New Mexico } \\
\text { (Adjacent to and South of study } \\
\text { area) }\end{array}$ & $\begin{array}{l}1859 \text { (date } \\
\text { confirmed) }\end{array}$ & Pueblo Community & Spanish & \\
\hline Rancho del Rio Grande & Taos Co., New Mexico & 1795 & $\begin{array}{l}\text { Hispano Protective } \\
\text { and Grazing }\end{array}$ & Spanish & \\
\hline
\end{tabular}


Table 2-3. (Cont.)

\begin{tabular}{|c|c|c|c|c|c|}
\hline Grant & $\begin{array}{l}\text { Location (within study area } \\
\text { unless otherwise indicated) }\end{array}$ & Year Granted & Type of Grant & Grantee & Comments \\
\hline $\begin{array}{l}\text { San (Don) Fernando de } \\
\text { Taos }\end{array}$ & Taos Co., New Mexico & $\begin{array}{l}1799^{1} \\
1796^{2}\end{array}$ & Community & Spanish & $\begin{array}{l}{ }^{1} \text { Sayles and } \\
\text { Williams, n.d. } \\
{ }^{2} \text { Center for } \\
\text { Land Grant } \\
\text { Studies } 2005\end{array}$ \\
\hline San Ildefonso Pueblo & $\begin{array}{l}\text { Santa Fe Co., New Mexico (SW of } \\
\text { study area) }\end{array}$ & 1689 & Pueblo Community & Spanish & \\
\hline $\begin{array}{l}\text { San Juan Pueblo (Ohkay } \\
\text { Owingeh) }\end{array}$ & Rio Arriba, Co., New Mexico & 1689 & Pueblo Cruzate & Spanish & \\
\hline Sangre de Cristo & $\begin{array}{l}\text { Costilla Co., Colorado and Taos } \\
\text { and Colfax Co., New Mexico }\end{array}$ & 1843 & Quasi-community & Mexican & \\
\hline Santa Barbara & Taos Co., New Mexico & 1796 & Community & Spanish & \\
\hline Santa Clara Pueblo & $\begin{array}{l}\text { Santa Fe and Rio Arriba Co., New } \\
\text { Mexico (SW of study area) }\end{array}$ & 1689 & Pueblo Cruzate & Spanish & \\
\hline Santa Cruz (de la Canada) & $\begin{array}{l}\text { Santa Fe and Rio Arriba Co., New } \\
\text { Mexico (South of study area) }\end{array}$ & $\begin{array}{l}1767^{1} \\
1695^{2}\end{array}$ & Community & Spanish & $\begin{array}{l}{ }^{1} \text { Sayles and } \\
\text { Williams, n.d. } \\
{ }^{2} \text { Center for } \\
\text { Land Grant } \\
\text { Studies } 2005 \\
\end{array}$ \\
\hline $\begin{array}{l}\text { Santo Domingo de } \\
\text { Cundiyo }\end{array}$ & $\begin{array}{l}\text { Santa Fe Co., New Mexico (South } \\
\text { of study area) }\end{array}$ & 1743 & $\mathrm{n} / \mathrm{a}$ & Spanish & \\
\hline Sebastian Martin & $\begin{array}{l}\text { Rio Arriba and Taos Co., New } \\
\text { Mexico }\end{array}$ & $\begin{array}{l}1751^{1} \\
1712^{2}\end{array}$ & Quasi-Community & Spanish & $\begin{array}{l}{ }^{1} \text { Sayles and } \\
\text { Williams, n.d. } \\
{ }^{2} \text { Center for } \\
\text { Land Grant } \\
\text { Studies } 2005\end{array}$ \\
\hline
\end{tabular}


Table 2-3. (Cont.)

\begin{tabular}{|c|c|c|c|c|c|}
\hline Grant & $\begin{array}{l}\text { Location (within study area } \\
\text { unless otherwise indicated) }\end{array}$ & Year Granted & Type of Grant & Grantee & Comments \\
\hline Taos Pueblo & Taos Co., New Mexico & $\begin{array}{l}1816^{1} \\
1793^{2}\end{array}$ & Pueblo Community & Spanish & $\begin{array}{l}{ }^{1} \text { Sayles and } \\
\text { Williams, n.d. } \\
{ }^{2} \text { Center for } \\
\text { Land Grant } \\
\text { Studies } 2005 \\
\end{array}$ \\
\hline Tesuque Pueblo & $\begin{array}{l}\text { Santa Fe Co., New Mexico (South } \\
\text { of study area) }\end{array}$ & 1689 & Pueblo Community & Spanish & \\
\hline Tierra Amarilla & $\begin{array}{l}\text { Archuleta Co., Colorado and Rio } \\
\text { Arriba Co., New Mexico (West of } \\
\text { study area) }\end{array}$ & 1832 & Quasi-community & Mexican & \\
\hline $\begin{array}{l}\text { Vigil and St. Vrain (Rio } \\
\text { Las Animas) }\end{array}$ & $\begin{array}{l}\text { Las Animas, Bent, Otero, Pueblo, } \\
\text { and Huerfano Co., Colorado (East } \\
\text { of study area) }\end{array}$ & 1843 & $\mathrm{n} / \mathrm{a}$ & Mexican & $\begin{array}{l}\text { Partially } \\
\text { adjudicated }\end{array}$ \\
\hline
\end{tabular}


Table 2-4. Definitions of Land Grant Types (after Center for Land Grant Studies 2005)

\begin{tabular}{|c|c|}
\hline Land Grant Type & Definition \\
\hline Private & $\begin{array}{l}\text { Grants made to individuals who owned the entire grant and could sell it after the four-year possession requirement } \\
\text { was met. These grants did not include common lands either at the outset or later. }\end{array}$ \\
\hline Community & $\begin{array}{l}\text { Grants made to a group of individuals that included common lands from the beginning. Settlers would receive } \\
\text { small tracts of private land for their houses and garden plots with the right to use the remaining common lands for } \\
\text { pasturing their cattle, gathering firewood and logs for building, hunting wild game, and gathering other resources. } \\
\text { Settlers owned their private tracts outright after four years and could sell them. The sale of a private tract by an } \\
\text { individual carried with it the right to use the common lands, but the common lands could not be sold because they } \\
\text { were owned by the community. }\end{array}$ \\
\hline Quasi-Community & $\begin{array}{l}\text { Grants made to individuals who owned the entire grant and could sell it after the four year possession requirement } \\
\text { was met. These grants included an explicit or implied promise by the grantee to bring other settlers on the grant, } \\
\text { and when those settlers arrived the grant would be operated like a community grant. The new settlers would } \\
\text { receive tracts of private land with the implied right to use the unallotted land for grazing, wood-gathering, and } \\
\text { other traditional uses. }\end{array}$ \\
\hline Protective & $\begin{array}{l}\text { These were grants made to protect the rights of an existing grant, for example up stream water rights. They may } \\
\text { not have required settlement. }\end{array}$ \\
\hline Grazing & $\begin{array}{l}\text { This was a grant to individual Hispanos for the purposes of grazing their livestock. Settlement on the land was not } \\
\text { required by law. }\end{array}$ \\
\hline Pueblo Community & Community grants made to a Native American Pueblo. \\
\hline Pueblo Cruzate & $\begin{array}{l}\text { Four square leagues of land granted to New Mexico Pueblos by Governor Domingo Jironza Petriz de Cruzate } \\
\text { (1683-1686 and 1689-1691). }\end{array}$ \\
\hline Pueblo Protective & $\begin{array}{l}\text { These were grants made to protect the rights of an existing Pueblo grant, in addition to their four square leagues, } \\
\text { such as upstream water rights. }\end{array}$ \\
\hline
\end{tabular}




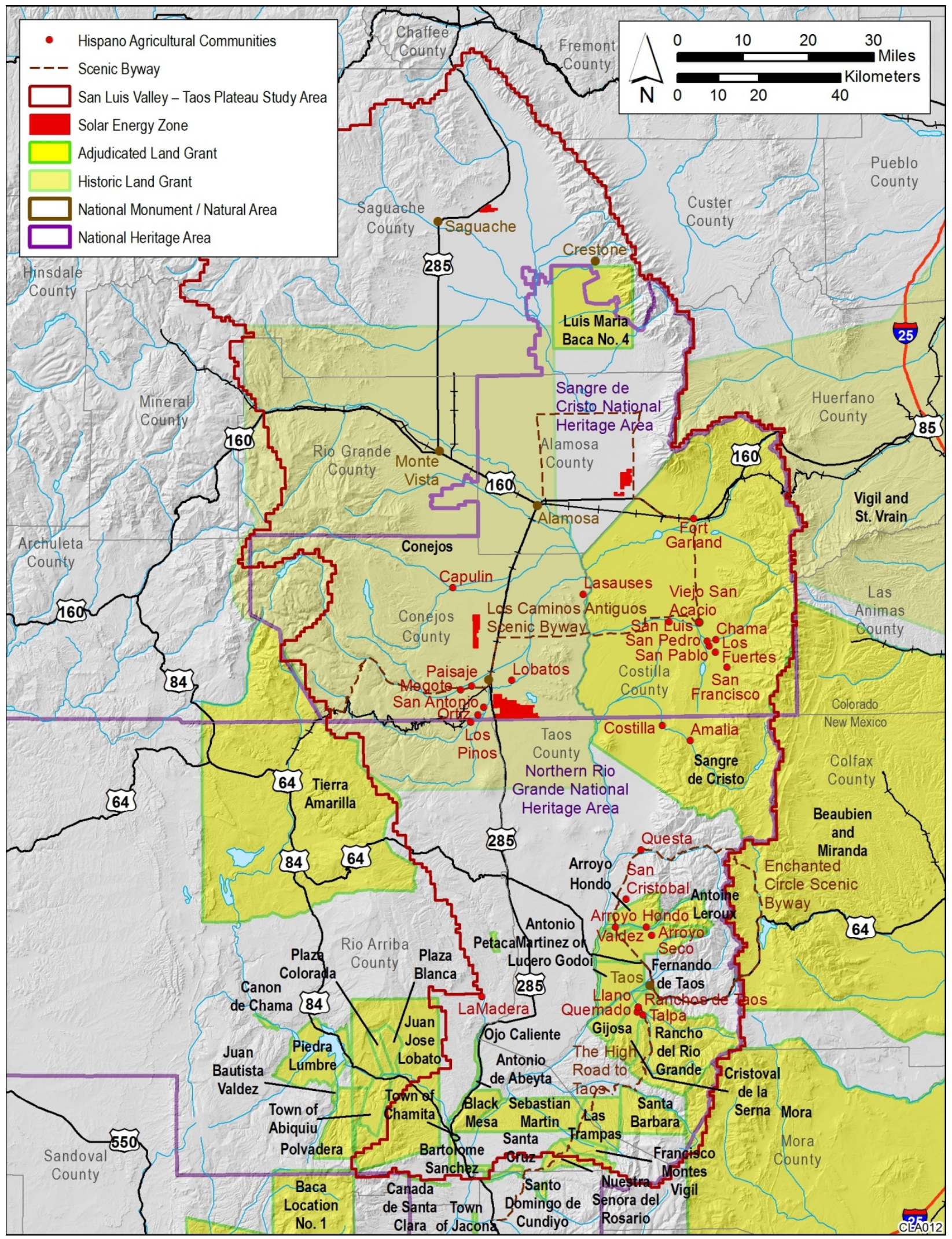

Figure 2-2. Land Grants within the San Luis Valley - Taos Plateau Study Area 


\subsubsection{Trading and Trapping}

The San Luis Valley - Taos Plateau opened up to the fur trade in 1821, when Mexico gained its independence from Spain. Until then, the Spanish government generally did not issue trapping licenses to foreigners in the Rio Grande Valley, often capturing and imprisoning French and American trappers who ventured into their territory. Among the first trappers in the valley were Hugh Glenn and Jacob Fowler, who entered the valley in 1822 via the Sangre de Cristo Pass. Following the Sangre de Cristo Creek to the east side of the San Luis Valley - Taos Plateau, they worked their way down to Taos, a principle trade and supply center and main point of departure for fur trappers. This trail later became known as the Trappers Trail or Taos Trail (Simmons 1999; Carter and Mehls 1984).

Glenn and Fowler's expedition encouraged many others to try their hand at trapping in the west, and during the 1820s and 1830s most people who ventured to Taos worked in the San Luis Valley - Taos Plateau or travelled through it on their way to Santa Fe or further west. By the 1830s an established trade network existed between Missouri and New Mexico and trading posts were established throughout Colorado, New Mexico and Utah. To reach Taos, many used the Trapper's Trail, but as the fur trade reached its height and as more operations became centered out of Santa Fe more people chose to use the Santa Fe Trail, which bypassed Taos and the San Luis Valley - Taos Plateau. Other famous trappers who were based out of Taos include Antoine Robidoux, Antoine Leroux, Kit Carson, and Tom Tobin. Native American tribes in the valley, particularly the Utes, also participated in the fur trade (Simmons 1999; Carter and Mehls 1984).

Changes in fashion by the 1840s reduced the demand for beaver fur and fur trading declined, but many trappers chose to stay in the valley. In the 1860s the buffalo robe trade became popular and former fur traders, both European and Native American, began hunting buffalo out on the plains. This ended by 1880 when the buffalo population was nearly decimated from over-hunting (Simmons 1999; Carter and Mehls 1984).

\subsubsection{Early Hispano Settlement/Early Farming and Ranching}

The San Luis Valley - Taos Plateau saw many changes in its settlement pattern in the mid-nineteenth century. The Native American population in the San Luis Valley - Taos Plateau dwindled as a number of treaties signed between 1850 and 1880 resulted in the extradition of the Ute and Jicarilla Apache peoples to reservations in western Colorado and Utah.

At the same time, the first Hispano settlements were developing in the region. The first Hispano settlements within the Valley were along Culebra Creek (Rio Culebra), within the Sangre de Cristo Land Grant. These include Plaza de los Manzares (now present-day Garcia) settled in 1849, San Luis in 1851, and San Pedro in 1852. San Luis is recognized as the oldest continually occupied settlement in Colorado. Other settlements within the Sangre de Cristo Land Grant include San Pablo, settled in 1853, San Acacio in 1856, and San Francisco (La Valle) in 1855 (SdCNHA 2013; Simmons 1999; Carter and Mehls 1984). Many of the people who currently live in the San Luis Valley are Spanish descendants of these earliest settlers (Valdez et al. 2003). 
South of San Luis, settlers constructed the first acequia systems in the study area. Acequia systems are hand-dug community irrigation systems that follow the curve of the land and move water by using the flow of gravity. The San Luis Peoples Ditch \#1 was constructed in 1851 and holds as the first recorded water right in Colorado. In 1852, both the San Pedro Ditch and Acequia Madre Ditch were constructed. The Monte Ditch, Vallejos and Manzanares Ditch, and Acequiacita Ditch followed in 1853, 1854, and 1855, respectively (Carter and Mehls 1984). Acequias are not just irrigation ditches but are an integral part of the sense of place and practices of traditional communities within the San Luis Valley - Taos Plateau. They exemplify the cores of Hispano culture, promote a strong land and water conservation ethic, and are intertwined with long-term community survival. For more information about the Hispano Communities relationship with acequia systems, the reader is directed to Acequia: Water-sharing, Sanctity, and Place (Rodriquez 2007) and The Village of Los Pinos: A Reconnaissance Survey (Valdez et al. 2003).

The Conejos Land Grant was first awarded in 1833. Approximately 80 families settled within the Conejos Land Grant, digging out acequias and planting crops, but quickly left because of a hostile environment. In 1848, Jose Martinez, Antonio Martines, Julian Gallegos, and Seledon Valdez reasserted their claim of the Land Grant and the claim was upheld (Valdez et. al 2003). In 1854, Juan Maria Jacques, Lafayette Head, and over 50 other families founded the town of Guadalupe, what is now the present-day town of Conejos. Within this settlement, they built Our Lady of Guadalupe Church, the first and oldest Catholic Parish in Colorado. The church is still located in Historic Conejos Plaza, although it was rebuilt after a fire in 1926. Additional early settlements within the Conejos Land Grant include Servillita and Mogote both settled in 1854. The first acequia systems constructed around these settlements were the Guadalupe Main Ditch and the Mills Head Ditch, both dug in 1855. By 1857, twenty additional ditches followed (Carter and Mehls 1984; SdCNHA 2013). Early settlements in the northern part of the San Luis Valley include La Garita and La Loma, near present-day Del Norte. Both were settled in the late 1850s.

Settlement patterns typically followed those of the Mexican and Spanish villages. Settlers initially lived in jacales, while more permanent adobe homes were being built. Adobe homes were constructed low to the ground around a central square or plaza. A large communal area, like La Vega just outside of San Luis, was sometimes designated outside of the plaza walls for pasture, hunting, fishing, and collecting timber. Plazas usually contained communal buildings such a church, bank, doctor's office, trading post, post office, and other business and communal areas. Early plazas were well-walled and fortified and settlers were required to have defensive weapons to protect themselves from Native American raids. Many of these original plazas still stand today and are important physical remains of early Hispano settlement and continue to be religious, familial and communal space, hosting a number of activities throughout the year including religious celebrations and fiestas (Higgins et al. 2013; SdCNHA 2013, Simmons 1999; Carter and Mehls 1984; Mondragon-Valdez 2000; Valdez et al. 2003).

Life for the early settlers of the San Luis Valley - Taos Plateau was not easy. Early Hispano settlers were mainly self-subsistent. They grew a variety of crops including corn, wheat, beans, chile, fava beans, white corn, onion, field peas, pumpkin, apples, and plums. They spun and wove fabric from their own sheep and goats and raised cattle, hogs, and chicken. Cattle and 
other stock were let to pasture on common lands. Indigenous plants, such as Oshá, lamb quarters, purselane, pinyon nuts, chokecherry and gooseberry were used for both food and medicine, a practice that still continues today. Farms were laid out in long narrow strips of land, often referred to as long lots that ran from the river's edge to the foot hills of the mountain. These lots were between 55 and 1,000 ft long and were typically less than $500 \mathrm{ft}$ wide and met the needs of the local population. Long lot farming had many advantages. It gave multiple farmers access to water, provided almost equal access to variation in soil types, and fostered a communal sense of place. Many individuals in the San Luis Valley still practice this type of agriculture. Cercas (fenced gardens) and roof farming were also practiced (Carter and Mehls 1984, Simmons 1999, SdCNHA 2013; Valdez et al. 2003).

Cultural patterns began to change in 1880 when trade centers began to shift toward railroad towns and away from plazas. Incoming Euro-American settlers purchased land from Hispano individuals in economic crisis and American-style farming and ranching started to take over. Despite the influx of Euro-Americans into the valley much of the traditional Hispano way of life has continued to present-day. (Valdez et al. 2003) Many of these early settlements have grown in population and contain modern amenities, but they maintain their historic integrity in both perception and sentiment. For example, the Villages of Ortiz and Los Pinos continue the use of acequia systems, long lot settlement patterns, and sustained cultural practices (Valdez et al. 2003).

\subsubsection{Late $19^{\text {th }}$ Century/Early $20^{\text {th }}$ Century Agriculture and Settlement} (1870-1930)

Many of the more prominent towns in the study area were established throughout the San Luis Valley in the late 1800s and early 1900s and were associated with either railroad, mining, or agricultural development including Mosca, Mesitas, Blanca, San Acacio, Jaroso, Antonito, Sanford, Romeo, Manassa, Alamosa, Center, Blanca, Del Norte, Hooper, La Jara, and Crestone.

In the late $19^{\text {th }}$ - early $20^{\text {th }}$ century agricultural practices shifted from traditional long lots towards larger American farms and ranches. Influenced by the Homestead Act of 1862, settlers came to the San Luis Valley - Taos Plateau looking for unappropriated land to claim for their own. Some emigrants purchased farms from Hispano farmers in economic crisis, assembling land into large-scale commercial operations like those at Medano Ranch and Zapata Ranch. Many original settlers kept their lands claims and those that did not were often hired to work Euro-American farms, choosing to build adobe homes near the towns where they worked. As farmland continued to be settled, long and complex public and privately-financed canal systems were dug to irrigate farmland. The population of the valley increased dramatically in the 1870s and 1880s when Mormon settlers from the southeastern US and Utah established the towns of Manassa, Sanford, and Richfield. Manassa and Sanford became prosperous agricultural communities. In 1887, the first artesian wells were drilled to tap the underground aquifer and within the next decade about three thousand were drilled throughout the study area (SdCNHA 2013; USFWS 2015). Near Taos, the Town of Carson was founded in 1908 but was abandoned two decades later when the 1930s drought made farming difficult (NRGNHA 2013). 
Changes in agricultural scale and technology throughout the early $20^{\text {th }}$ century greatly altered the traditional Hispano communities in the study area. As farms grew and crops diversified new types of agricultural storage facilities began to dot the landscape. Lettuce, spinach, peas, chili peppers, barley, beans, oats, and hay were important crops to come out of the valley and cattle and sheep became very important industries for the San Luis Valley - Taos Plateau (Simmons 1999; SdCNHA 2013). Traditional acequia systems were used less frequently and water was restricted. The newer canal systems reached higher benches, and the artesian wells watered lands wherever drilling succeeded. Mechanized agricultural production was introduced and wealth shifted towards commercial scale farming endeavors, whose large tracts of land could support more crops and stock than those of the Hispano communities who still practiced subsistence agriculture (Mondragon-Valdez 2000; Wyckoff 1999). Commercial monocropping, failed water supplies, over-grazing, droughts and floods further transformed the landscape as many farms failed and farmers fled the valley. The agricultural market crashed during the Great Depression and several small communities disappeared (Mondragon-Valdez 2000).

\subsubsection{Modern Agriculture (1945-Present)}

Agricultural practices were altered considerably in the 1950s, when mechanized center pivot irrigation was introduced. Center pivot irrigation systems tap into a well that has been drilled into an aquifer at the center of a crop field. An irrigation pipe attached to the well and mounted on wheels is then gradually moved in a circle around the field. This type of agriculture now dominates the study area. Almost all of the center pivot systems are found in Colorado, in the northern and western portions of the San Luis Valley - Taos Plateau, although a small cluster of center pivot farms is located southeast of Ute Mountain, in Taos County, NM.

Major crops in the study area include potatoes, lettuce, spinach, alfalfa, and barley. Sixty percent of the San Luis Valley's barley is grown for the Coors Brewing Company. Much of the study area is also use for grazing. In the southern portion of the San Luis Valley - Taos Plateau, Hispano agricultural traditions are dominate (SdCNHA 2013) and traditional long lot farming using acequias and sustainable farming methods are still practiced (New Mexico Acequia Association 2010; Taos Valley Acequia Map n.d.). For example, small farms like Rezolana Farm in San Luis and Absmeier High Altitude Garlic are Certified Naturally Grown farms that focus on ecologically sustainable farming and ranching techniques. The site of Rezolana Farm has been worked by the Valdez Family for over 40 years. They continue to grow heirloom varieties of bolita beans, chico corn, fava beans, and dry white peas while experimenting with growing hemp and quinoa with low-till farming methods, planted cover crops and without the use of synthetic chemicals. Another example is the Rio Culebra Cooperative (RCC), a farmer-owned cooperative in Costilla County. The RCC represents 240 families in the Culebra watershed who still operate, use, and maintain acequias to irrigate their farms and ranches. RCC members produce $100 \%$ grass-fed beef and lamb, and/or heirloom varieties of bolita and haba beans, and chicos corn grown using sustainable ranching and farming techniques passed down through generations, such as rotational grazing, seed saving, and forgoing the use of pesticides, herbicides, and added hormones (RCC 2015; SdCNHA 2013). 


\subsubsection{Mining}

Pre-Columbian mining within the San Luis Valley - Taos Plateau included micaceous clay sources used for pottery and turquoise used for pendants. Micaceous clay and turquoise sources are located in several areas throughout the San Luis Valley - Taos Plateau.

Micaceous pottery has been in production for over 700 years among the Taos, Picuris, San Juan, Santa Clara, San Ildephonso, Pojoaque, Nambe, Tesuque, Jemez and Jicarilla Apache peoples. Use of micaceous clay in ceramic production is thought to have originated in the Tewa Basin, southwest of Taos, around 1300 AD and spread to the middle Rio Grande and northeastern New Mexico by 1500 or 1550 A.D. It is believed Hispanic potters, many of whom were descended from Native Americans, began to produce micaceous pottery sometime between 1790 and 1850 (Eislet and Ford 2007).

Various micaceous clay sources are located throughout the Sangre de Cristo Mountains and southern San Juan Mountains. The mica found within the clay acts a natural temper which increases the plasticity of the clay during production as well as the durability and heat resistance of finished ceramic vessels (Eislet and Ford 2007). The micaceous clay sources of the San Luis Valley - Taos Plateau are residual, meaning they are formed by surface weathering of nearby mica deposits. Potters choose clay for different types of vessels based on its texture. Each deposit contains different amounts of mica, making some deposits more suitable for ceramic cooking vessels, others for vases or decorative pots. Some deposits are considered unusable. Each deposit also carries its own chemical signature making it possible to determine which source of micaceous clay a specific ceramic vessel was made from (Eislet and Ford 2007).

Historically micaceous clay vessels were utilitarian items used for cooking and storage, however, since 1990 micaceous pottery has grown in popularity as collectible art (Eislet and Ford 2007; Anderson 1999).

The King Turquoise Mine, known historically as the Lickskillet Turquoise Mine exists near the Town of Manassa in Conejos County. The Zuni are thought to have been the original proprietors of the mine and it may be the mine from which Turquoise Old Man and Salt Old Woman brought stones to start the Zuni Turquoise Mine at Cerrillos, New Mexico (White 2005). Turquoise has also been mined for centuries at the Villa Grove Turquoise Mine, historically known as the Hall Turquoise Mine within the Bonanza District. Many historic Navajo and Zuni pendants were made from Villa Grove Turquoise (Turquoise Museum 2015).

Evidence of early Spanish mineral expeditions have been found in and around the old mining camps of Duncan and Liberty in the foothills of the Sangre de Cristo Mountains and along the western side of the valley in the form of primitive mining tools and arrastras, large, mill-like devices made of stone used for crushing ore. The San Luis Valley Gold Rush, however, didn't begin until the 1870s. Gold and silver were discovered near Summitville, east of the study area, in the San Juan Mountains, in 1870. Mines began to pop up in and along the San Juan Mountains and the mining districts of Bonanza, Creede, and Crystal Hill soon were settled. Del Norte, established in 1872, was a supply center for the San Juan Mining camps (USDA 2014). In 1879 a large gold deposit was found north of Crestone and rumors of gold brought an influx of 
prospectors to the east side of San Luis Valley - Taos Plateau. Soon, gold-bearing deposits were found in the mountains and creek beds along the northeastern portion of the study area and nine mining districts were established: Raspberry Creek, Orient, Crestone, Spanish, Cottonwood, Sangre de Cristo, Duncan, Liberty and Camp Commodore (Lowers 2014; Buchanan 1971).

Remains of several of these mining districts serve as recreational and educational opportunities for the San Luis Valley. Orient Mine, located in the northeastern corner of the valley, in the Sangre de Cristo Mountains, was active from 1880 through 1932. At its peak, it was the largest producer of ore in Colorado. The town of Orient had a population of over 400 and contained a library, barber shop, 2 restaurants, a milling company and a boarding house. Today, the mine is significant for its bat population and is designated a Colorado Natural Area and Colorado Division of Wildlife Watchable Wildlife Site. It is part of the larger Oriental Land Trust which operates the Valley View Hot Springs Resort, the Bat Cave at the Orient Iron Mine and Everson Ranch. All that remains of the once booming mining town are a few foundations (Orient Land Trust 2015).

The Bonanza Mining District, located on the east side of the valley, around present-day Crestone, was active from 1880s-1930s. At its peak it produced over 150 tons of silver and boasted a population of around 500 and contained saloons, dance halls, a school, a bank, a sawmill, plank sidewalks, and even a town baseball team. Several mills were built in the surrounding area to process the silver ore. During the 1890s, many mines failed as it was discovered that the deeper ores contained less of the profitable silver ore and more lead, zinc, and copper, which were harder to mine. Rawley Mine, one of the larger mines in the district continued to operate until the 1930s, adapting with new technology. In 1917 it replaced its underground mule train with a locomotive and in 1923, built an aerial tramway to haul ore from the Rawley Mine mill to the narrow gauge railroad line that connected with Salida. A fire destroyed most of the historic mining district in 1937 and all that remains are a few houses, mines structures, and rock piles. Liberty Mine, now a ghost town accessed by the Liberty Trail from Liberty Trailhead near the Great Sand Dunes, produced lead, silver, zinc and to a lesser extent gold. The Bonanza Mining district also contained the Villa Grove Turquoise Mine which produced high quality turquoise from 1937 through the 1950s (Cappa and Wallace 2007; Saguache County 2015).

The Crystal Hill Mining District, located in the northwest corner of the valley near present-day La Garita was founded in 1881 by prospector Mark Biedell. The district produced gold and silver until operations ceased in 1900. Two small mining camps are associated with the Crystal Hill Mining District: the first, called Biedell after its founder, was founded in 1881, and the other was formed in 1886 and was called El Carnero. All that remains of these historic towns are a few dilapidated buildings, mine structures, and rock piles. The mine was reworked in the 1980s, but is now closed.

In the 1920s, molybdenum mines opened near Questa, New Mexico, north of Taos. Large scale open-pit mining operations began in the 1960s and returned to underground mining in the 1980s (NRGNHA 2013; EPA 2015). At the time of operation, it was the area's largest employer (NRGNHA 2013). The mine is currently on EPAs National Priorities List (EPA 2015). 
Today, sand and gravel are the major mineral commodities in the San Luis Valley, with small gold, silver, peat, uranium, clay, limestone, and turquoise operations scattered throughout the valley (Colorado Division of Reclamation, Mining and Safety 2015; Turquoise Museum 2015; NRGNHA 2013).

\subsubsection{Trails and Transportation}

At the time of Spanish arrival, the Ute, Jicarilla Apache, Navajo, Kiowa, Comanche, Tewa and Tiwa Pueblos and possibly others had at one point or another journeyed into or out of the valley into the surrounding mountains and plains in search of search of food, water, and shelter via a defined route previously travelled by their ancestors. Spanish, and later American, explorers like De Vargas, Freemont, and Gunnison, capitalized on Native American knowledge of the area, often following Native American trails in search of fur-bearing mammals, minerals, or overland routes to California. In cases where defined routes were not available, they blazed their own trails. Early historic trails were not single-track routes, but rather travel corridors in which the route of travel varied due to the type of pack animal or mode of transportation used as well as weather conditions, but by the $19^{\text {th }}$ century many of these trails were improved as wagon roads by private or government road builders. Today, many of those trails and travel corridors used by Native Americans; Spanish, Mexican, and American Explorers; fur-traders; and emigrants are still in use as major thoroughfares.

One important early Native American trail is the Picuris Trail, which lead from the Picuris Pueblo into the San Luis Valley, and was used from prehistoric times through the 1850. This route was used by the Picuris, Navajo, Jicarilla Apache, and possibly the Ute and residents of the Santa Clara and Ohkay Owingeh Pueblos while fleeing their homes during the Spanish Reconquest. Although this trail is no longer in use, remnants can be seen today in Colorado, up to the New Mexico-Colorado border and it represents an important part of the Picuris People's past. The Picuris have expressed the importance of this feature (Higgins et al. 2013).

There are many historic trails within San Luis Valley - Taos Plateau related to exploration, military campaigns or industrialization. While all of these have been considered in this cultural assessment, we only discuss the most prominent historic roads and trails in this section including, the El Camino Real de Tierra Adentro, the Old Spanish Trail, and the Taos Trail (also known as Trappers Trail), A full list of trails, passes, and transportation corridors analyzed for this assessment is provided in Appendix B, Table B.1.

The El Camino Real de Tierra Adentro (The Royal Road of the Interior) National Historic Trail (El Camino Real NHT) is a historic route of travel, trade, and interaction that connected the lives of early Spaniards, other Europeans, American Indians, Mexicans, and Americans (NPS 2012). The El Camino Real de Tierra Adentro is located at the southern end of the study area. It enters the study area near Santa Cruz, New Mexico and generally follows the route of NM Route 106 north and northwest to the present-day road, Jack Rabbit Trail. The trail continues north along Jack Rabbit Trail to NM Route 74 and through the Ohkay Ohwengeh Pueblo before circling back south towards Espanola, generally following North Prince Drive into Espanola. Use of the 1,400-mile trail from Mexico City, Mexico, to San Gabriel de YunqueOuinge (the present-day San Juan Pueblo, New Mexico) began in 1598 and continued until the 
arrival of the railroad in 1880 (NPS 2012). In 2000, El Camino Real de Tierra Adentro was recognized for its national and international significance in the shaping of the southwest, and its section from El Paso, Texas, to San Juan Pueblo, New Mexico, was added to the National Trails System through Public Law 106-307 (NPS and BLM 2004). El Camino Real de Tierra Adentro Corridor has also been designated as a state scenic and historic byway, a national scenic byway, and a Millennium Legacy Trail (NPS and BLM 2004). In 2010, the segment of the trail that resides in Mexico was designated as a World Heritage Site (NPS 2012, UNESCO 2012).

The Old Spanish National Historic Trail (OST) is a historic trade route linking Santa Fe, New Mexico and Los Angeles, California. The trail, a combination of Native American trade and travel routes, was formally established as regular overland route west to California in the late 1820s by the Spanish. The North Fork of the Old Spanish Trail left Santa Fe and entered the San Luis Valley - Taos Plateau on two different routes- an eastern and a western branch. The eastern branch of the North Fork, officially designated by Congress as a route of the Old Spanish Trail of historic national significance, passes through Taos and roughly follows the base of the Sangre de Cristo Mountains before turning west and following what is now County Road Aa into Saguache and then into the Cochetopa Pass. The western branch, still under study, roughly follows the route of US 285 to Saguache where it joins with the eastern branch before it enters Cochetopa Pass (NPS 2001). The Old Spanish Trail was designated by Congress as a National Historic Trail in 2002 for its national significance within the theme of the "Changing Role of the United States in the World Community" and the topics of trade and commerce, during the period of 1829-1848 (NPS 2001; Old Spanish Trail Recognition Act of 2002). Representatives of the Hispano community in the San Luis Valley - Taos Plateau have indicated that although the Old Spanish Trail brought new settlers to the area and stimulated trade, it also had a negative impact on plants and animals through over-hunting, over-grazing, and timber harvesting. Hispano representatives have also indicated that they are concerned about the damage use of the trail could cause especially from vehicular travel (Stoffle et al. 2008).

The Taos Trail, or Trappers Trail, linked Taos, New Mexico and the San Luis Valley Taos Plateau to the Santa Fe Trail, an established overland trade route linking Franklin, Missouri with Santa Fe, New Mexico, via the Sangre de Cristo Pass. This trail allowed trappers to access Taos, the principal trade and supply center in the Southern Rockies, without having to travel south to Santa Fe first. Stage lines were later established along the Taos Trail to transport people, freight, and mail (Simmons 1999).

After Colorado gained territorial status, the development of infrastructure throughout Colorado became increasingly important. The Homestead Act of 1862 coupled with the Indian Treaty of 1863 opened up much of the study area for settlement. Settlement in the valley increased rapidly and transportation quickly became a concern. Several toll roads, which provided convenient access into the San Luis Valley - Taos Plateau and remote areas of Colorado surrounding the study area were constructed in the late $19^{\text {th }}$ century to accommodate a growing population and an influx of supplies and food. Otto Mears, a Russian immigrant turned entrepreneur funded three major toll roads in the San Luis Valley - Taos Plateau; one over Poncha Pass in 1867, another through Cochetopa Pass in 1871, and a third, the Saguache and San Juan Toll Road in 1874, thereby improving both passes for trade and travel. Other toll roads, 
such as the Antelope Park Toll Road, opened up areas to development such as mining and settlement (Simmons 1999).

The railroad also moved quickly west. In 1870, William Jackson Palmer filed for incorporation of the Denver and Rio Grande Railroad (D\&RG). The D\&RG utilized a narrowgauge track, with only three feet in between the rails to negotiate the steep and narrow curves of the Rocky Mountains. By 1877 the D\&RG had reached the San Luis Valley northeast of Fort Garland. The temporary end-of-track town of Garland City sprung up and lasted for about one year until the tracks reached westward to the Rio Grande, where Alamosa was plotted and quickly grew to be the commercial center of the valley. The D\&RG continued southward, linking Antonito, CO to Santa Fe, NM by way of then the D\&RG Chili Line. The Chili Line was a narrow-gauge rail line named after its main source of freight, red chili peppers, which were grown by the farmers along the line. Its last run was in September 1941 because use of the line had been dwindling since the Great Depression and the railroad was no longer profitable (Time 1941). The D\&RG also expanded south to Chama, New Mexico by way of the D\&RG San Juan Extension. In 1881, D\&RG concentrated efforts on extending the line westward from Alamosa to Del Norte to capitalize on the mining traffic. That same year, D\&RG extended their northern line into San Luis Valley through Poncha Pass, ending the line at the iron mines southeast of Villa Grove. In 1890, D\&RG connected the line at Alamosa. In the 1950s and 1960s D\&RG rerouted much of the narrow-gauge track with a standard-gauge track and the line through Poncha Pass was dismantled as was most of the San Juan Extension. In 1970, Colorado and New Mexico, with support from the public, jointly purchased the remaining portions of the San Juan Extension including some of its locomotives, structures, and rail yards and for tourist development. Today the railroad is operated as the Cumbres and Toltec Scenic Railroad offering daily trips between Antonito, Osier, and Chama (Simmons 1999; C\&TSRR 2015.) In 2012, the Cumbres and Toltec Scenic Railroad was designated as a National Historic Landmark for its "outstanding representation of the original D\&RG "as it contains "the longest and most complete example of the late nineteenth-early century railroading in the nation" (C\&TSRR 2012).

In later years, two independent short line railroads were constructed to meet the needs of growing farming communities. The San Luis Valley Southern Railroad which operated between Blanca and San Acacio was completed in 1910 and the San Luis Central, which operated from Monte Vista to Center, was completed in 1913. Both lines mainly served agricultural communities by hauling produce and fertilizer. The San Luis Central still operates seasonally, but the San Luis Valley Southern was dismantled in the late 1950s (Simmons 1999).

Modern transportation networks like the Los Caminos Antiguos Scenic and Historic Byway and the Enchanted Circle Scenic Byway are working to promote historic resources and recreational opportunities throughout the valley. Los Caminos Antiguos Scenic and Historic Byway is located in south central Colorado, in Conejos, Costilla, and Alamosa counties. The byway consists of Alamosa County Lane 6, US 150, US 285, US 160, CO 17, CO 159 and CO 142 as well as city streets in Antonito, Romeo, Manassa, San Luis, and Fort Garland. A main tourist destination in San Luis Valley - Taos Plateau, the purpose of the Los Antiguos Caminos Historic and Scenic Byway it to "Interpret, facilitate community development, and market the products of the cultural and historic traditions, natural resources, and diverse communities" (LCASB 1999). Stops along the byway include the Great Sand Dunes National Park and 
Preserve and the Cumbres and Toltec Scenic Railroad Depot (Colorado Tourism Office 2015). The original route of the Los Caminos Antiguos Scenic and Historic Byway was designated by the State of Colorado in October 1991 and an additional extension was designated in June 1992 (LCASB 1999).

Enchanted Circle Scenic Byway is an 83-mile loop through northern New Mexico. The byway centers around Wheeler Peak, New Mexico's highest point (13,161 ft) and travels through mountains, valleys, mesas, and National Forests, linking the towns of Questa, Taos, Angel Fire, Eagle Nest, and Red River continuing on into Taos Ski Valley. The Enchanted Circle was designated as a National Forest Scenic Byway in 1989 and was designated by the State as one of New Mexico’s Scenic Byways in July 1998. The Enchanted Circle Scenic Byway provides a variety of recreational activities and tourist destinations (Enchanted Circle 2015).

\subsubsection{Urbanization}

The City of Alamosa is the largest city in the San Luis Valley - Taos Plateau. Founded in 1878 as a railroad town for the D\&RG, the town serves as this part of southeastern Colorado's center for aggregation and distribution of resources. Alamosa also holds the area's primary medical facility, Alamosa Hospital, as well as the valley's primary educational facility, Adams State University. These are the area's two largest employers, respectively (SdCNHA 2013).

The City of Taos is the second largest city in the San Luis Valley - Taos Plateau. Officially incorporated in 1934, the City of Taos has been a mecca for artists since 1899. Taos serves as the Taos County seat and holds the area's primary medical facility, Holy Cross Hospital, and educational facility, Southern Methodist University. Just outside Taos is the Earthship Biotecture community, a community of sustainable homes designed from natural and recyclable materials (Earthship Biotecture 2015).

The City of Antonito is the third largest city in the San Luis Valley - Taos Plateau. Founded in 1880 as a switching station for the Chili Line extension, the city served as a critical link to Chama, New Mexico. Between Alamosa and Antonito are the small historic towns of Manassa and Sanford. Originally Mormon communities, locations were chosen with the assumption that the railroad would soon be built nearby. However, the railroad was built three miles west. Other towns that sprang up against rail lines include, La Jara, Blanca, Romeo, New San Acacio, Mesita, Jaroso, Mosca, Hooper, and Fort Garland which all served as secondary rail shipping points and supply centers. All of these communities were developed from a platted grid system derived from the U.S. Public Land Survey System (SdCNHA 2013).

The pattern of development in railroad communities like Antonito and Alamosa is significantly different from the pattern of development of Hispano communities where town centers were oriented around plazas. Today, this type of development is most present in San Luis and Taos as well as other smaller communities throughout the Southern San Luis Valley - Taos Plateau including San Acacio Viejo, San Pedro, San Francisco (La Valley), San Pablo, Los Fuertes, San Antonio, San Francisco, Garcia, Conejos, Guadalupe, Chama, Las Mesitas, Los Cerritos, Las Sauces, Ortiz, Cañon, Mogote, Paisaje, Espinosa, Capulin, and Lobatos (Cenicero) (SdCNHA 2013). 
Population in the San Luis Valley - Taos Plateau reached its peak in the 1940s after which it plummeted. Population continued to decline through the 1980s and 1990s with a small increase in population occurring throughout the early 2000s and then declining slightly again. Today, the area remains predominantly agricultural (both farming and ranching) with a growing medical and educational industry as well as a predominant artist community. The San Luis Valley - Taos Plateau also relies heavily on tourism from local National Forests, National Parks, BLM lands, recreational facilities, such as ski resorts, and historic and cultural sites (SdCNHA 2013 and NRGNHA 2013).

\subsubsection{Ethnic and Religious Influence}

While there is little doubt that the San Luis Valley - Taos Plateau has been predominately shaped by Hispano culture, a number of other ethnic, cultural, and religious populations are represented throughout the study area. Some groups settled in the valley after serving in the military, some for the promises of a better life, and some came to escape religious and ethnic persecution. While the Catholic population remains dominant, populations of Native Americans, Euro-Americans, Japanese-Americans, African-Americans, Mayan Indians, and Mormons are represented throughout the San Luis Valley - Taos Plateau. The Crestone Community is home to centers of the world's religious traditions and is currently the largest intentional interfaith community in North America. In their ethnographic volumes, White (2005) and Higgins et al. (2013) present a good discussion of ethnicity and culture within the San Luis Valley and the role these different groups played in the history and settlement of the valley. Higgins et al. (2013) also presents a short discussion on Spanish-Jewish Descendants and White (2005) presents an excellent description of the highly spiritually diverse Crestone Community. Other discussions on the role ethnic and religious groups played in shaping the San Luis Valley Taos Plateau can be found in Simmons (1999) and Mondragon-Valdez (2000). The reader is referred to those volumes for more information on this topic.

\subsubsection{Recreation and Government}

Today, the San Luis Valley - Taos Plateau remains rich in history, culture, and tradition. It contains numerous conservation and recreation areas at both the State and Federal level (see Figure 1-1). The Bureau of Land Management (BLM) administers over 900,000 acres of land in the Study Area (see Table 2-2). From the New Mexico-Colorado border south to the Rio Grande Gorge Visitor Center, 242,455 acres of the Taos Plateau have been designated as the Rio Grande del Norte National Monument. The BLM works with other Federal, state, private, and tribal agencies to protect the natural and cultural resources of the monument (BLM 2014b). The U.S. Fish and Wildlife Service (USFWS) manages the Baca, Monte Vista, and Alamosa National Wildlife Refuges (collectively called the San Luis Valley National Wildlife Refuge Complex), conservation areas set aside for migratory birds and wildlife. The Baca Wildlife Refuge also protects 12,000 years of archaeological history from the Paleoindian through historic period (USFW 2015). The U.S. Forest Service (USFS) manages the Rio Grande and Carson National Forests, both of which surround the eastern and western sides of the San Luis Valley - Taos Plateau. Great Sand Dunes National Park and Preserve, on the east side of the valley, just north of Blanca Peak, is managed by the National Park Service. State owned recreation and 
conservation lands include the San Luis Lakes State Park, 13 State Wildlife Areas, and 11 State Trust Lands managed by the Colorado Department of Natural Resources. A number of municipal and county recreational lands are scattered throughout the study area as well.

Most of the study area is located within the Sangre de Cristo and Northern Rio Grande National Heritage Areas (NHAs). The Sangre de Cristo NHA includes Alamosa, Conejos, and Costilla counties in Colorado, as well as the San Luis Valley National Wildlife Refuge Complex and the Great Sand Dunes National Park and Preserve (SdCNHA 2013). The Northern Rio Grande NHA extends north to south from the Colorado border to the center of New Mexico and east to west between the Sangre de Cristo and San Juan Mountain Ranges and encompasses eight Indian Pueblos: Taos, Picuris, Ohkay Owingeh, Santa Clara, San Ildefonso, Pojoaque, and Tesuque, as well as the Jicarilla Apache Nation (NRGNHA 2013). It is the goal of both of these National Heritage Areas to tell the story of the history and perseverance of the people who reside within them and to preserve the culture and tradition of its residents as well as the physical and cultural landscapes they helped shape. Both National Heritage Areas aim to foster a better understanding of cultural identity and historic ties to the land by providing educational programs and heritage tourism, supporting sustainable economic opportunities, and increasing community collaboration in a way that does not interfere with traditional life ways (SdCNHA 2013; NRGNHA 2013). 
Final SLV-TP Landscape-Level

October 2016

Cultural Heritage Values and Risk Assessment

Page Intentionally Left Blank 


\section{CULTURAL CONSERVATION ELEMENTS REGIONAL RESEARCH DESIGN}

This section deviates from the organizational structure of the REAs and Landscape Assessment in order to incorporate a regional research design, a common cultural resource management tool that is used to organize and prioritize research themes and questions that could be realistically addressed from the archaeological or ethnographic record for a given area. The regional research design also identifies data gaps as well as data that need to be collected in order to fill in those gaps and/or answer posited research questions. A regional research design affords land managers the opportunity to identify the types and distribution of cultural resources that are present as well as those that could be encountered within a specific area. With this information in hand, land managers are in a better position to assist developers during pre-application meetings in avoiding areas of potential impact and/or explaining the mitigation requirements that may occur within a given area.

For this regional research design, cultural conservation elements are used to represent regionally significant focus areas. These were derived from a review of historic, archaeological, and contemporary ethnographic data. As stated in Chapter 2, cultural conservation elements were chosen in consultation with the BLM interdisciplinary team involved in Colorado SRMS efforts. Cultural conservation elements represent regionally significant focus areas derived from a review of historic, archaeological, and contemporary ethnographic data. Seven cultural conservation elements were selected for evaluation in the San Luis Valley - Taos Plateau cultural assessment (see Table 1-2). The primary objectives of this chapter are to 1) describe the components of each cultural conservation element 2) identify research avenues and questions related to each cultural conservation element, and 3) to identify the kinds of data needed to address those questions.

\subsection{Places of Traditional Cultural Importance to Tribes}

Many Native American tribes have spiritual, emotional, and contemporary ties to the San Luis Valley - Taos Plateau. Within the study area are culturally important natural resources and significant cultural landscapes that serve as the settings for tribal histories and spiritual narratives. Contemporary ways of life are rooted in traditions influenced by these sacred spaces and past experiences. These places are integral to Native American practices and beliefs and are important for maintaining a community's cultural identity. (It is important to note that these places have not been formally designated as traditional cultural properties that are listed on the National Register of Historic Places, but this assessment recognizes them as places of traditional importance that could receive that formal status at some point in the future.)

Places of traditional cultural importance were identified through a review of ethnographic literature (Higgins et al. 2013; Stoffle et al. 2008; White 2005), as well as expert knowledge from those who have worked with tribes in the area, and include mountain peaks, volcanic domes, river crossings, geological formations, Pueblos, battle sites, lakes and wetland areas, canyons, archaeological sites, trails, and shrines. These places are discussed throughout Section 2 of this document. 


\subsubsection{Data Needs and Research Avenues}

This cultural conservation element represents locations of known cultural importance; however, there are undoubtedly areas of cultural importance that have not yet been recorded. Ongoing consultation opportunities for tribes to identify potential effects on places of traditional cultural importance within the region should be made available during solar development (or other) land management planning efforts. Locational information regarding properties that are identified as places of traditional cultural importance in the future may be considered confidential and should remain so if requested; but nonetheless could be incorporated into the broad-scale analysis for a comprehensive planning effort without calling unwanted attention to a specific location or area.

Additional studies in this area could address key research domains presented in Martorano et al. 1999, including questions related to interregional influence, demography, cultural affiliation, and social organization, and provide key information for further conservation of these important resources.

\subsubsection{Research and Land Use Management Questions}

- Where are the important places of connectivity among landscape features and are these areas manifested in oral histories or the archaeology of the region?

- Are there locations of importance that are at risk of being lost or forgotten? If so, can additional research (archaeological or ethnographic) help rejuvenate the collective memory?

- How are the tribe's cultural traditions, oral histories, art, and food and resource procurement practices represented within the current landscape? How can these be preserved in a way that is beneficial to the tribe while maintaining the integrity of the landscape?

- How has water influenced access and use of important places within the ecoregion? How and why has this changed over time?

- How can the elements of the cultural landscape identified in the cultural assessment help to tell the stories of the people of the San Luis Valley - Taos Plateau?

- There are many important physical, spiritual and ceremonial locations for Native American tribes within the landscape. Can the results of this cultural landscape assessment help identify additional areas of importance to Native American tribes and/or corroborate and elaborate on existing oral histories?

- How do spaces within the landscape contribute to oral histories and contemporary community memory? 
- Are places of traditional use being impacted currently and by what activities? How will future development continue to impact these areas?

- In what ways does development influence places of traditional cultural importance? Is it a direct intrusion or desecration/disturbance? Is it visual, auditory, symbolic, personal, emotional, spiritual, all or some of the above? Is it different for each tribe, each individual? If so, in what ways?

- What types of mitigation can be applied and would be acceptable to the tribe(s) to alleviate the effects of specific change agents on an important place over time?

- The study area is a broad cultural landscape. Are there specific cultural values that either support or oppose solar (or other types of development) within the San Luis Valley? Is there a community interest in solar energy development?

- Will development in the ecoregion inhibit a feeling of pride in the landscape and/or constrain the cultural identity of those whose livelihoods are entwined with the landscape?

\subsection{Traditional Resource Collection Areas}

The valley is home to many plants, animals, and minerals historically and contemporarily used and valued by Native American and Hispano communities. Representatives of the Jicarilla, Navajo, Ute, Picuris and Hispano communities have all identified specific locations within the valley that contain plants and animals that have been or are currently used as raw material for cultural items as well as food, fuel, and medicinal and ceremonial purposes.

Traditional resource collection areas were identified through a review of ethnographic literature (Higgins et al. 2013; Stoffle et al. 2008; White 2005) and SHPO data, as well as information based on local expert knowledge. Places identified under this cultural conservation element include oshá collection areas, wetlands, culturally-modified tree clusters, pinyon-juniper woodlands, La Botica, the Punche Valley, and micaceous clay sources and are discussed throughout Section 2 of this document.

\subsubsection{Data Needs and Research Avenues}

This cultural conservation element represents known traditional resource collection areas; however, there may be collection areas that have not been identified. Furthermore, the location and/or importance of traditional resource collection areas may change over time depending on how collection areas respond to environmental changes as well as the needs of the community. Ongoing consultation opportunities for tribes and Hispano communities to identify new locations or changes in location as well as potential effects to these resources should be made available during land management planning efforts.

There may also be collection areas that were once utilized by prehistoric and historic peoples that contemporary individuals are not aware of. In order to identify unknown collection 
areas in the archaeological record, it may be useful to identify what types of features and artifacts, if any, best represent these areas. For example, areas that contain manos and metates or other food processing tools may indicate proximity to collection areas.

\subsubsection{Research and Land Use Management Questions}

- Which known traditional resource collection areas are still in use today? Are there others?

- Why are these areas still being used? Materials for survival? Art? Religious/ceremonial reasons? What would precipitate abandonment of a collection area, other than extinction of a resource?

- How have traditional resource collection areas changed over time?

- What types of features and artifacts in the archaeological record can help us identify resource collection areas that are no longer being used?

- How did bark peeling fit into seasonal subsistence patterns, and can locations of peeled trees be utilized to hypothesize seasonal movements during the Protohistoric/Historic Period? (from Martorano et al. 1999)

- Can the distribution of culturally peeled trees be compared to scar dates to hypothesize seasonal movements and migrations of specific cultural groups such as the Ute, Apache, or Navajo? (from Martorano et al. 1999)

- Were inner bark substances utilized most often in specific locations such as near campsites, trails, or mountain passes? (from Martorano et al. 1999)

- What is the temporal span for bark peeling of ponderosa pine trees within the Rio Grande Basin and which cultural groups were responsible? (from Martorano et al. 1999)

- What percentage of the community relies on resources from traditional collections areas for food, firewood, medicine, or for economic or social reasons? What are the social and economic impacts to communities from future development, invasive species, insects, and disease, wildfire, and climate change affecting these resources?

- What types of mitigation can be applied to alleviate the effects of specific change agents and ensure continued access to the specific locations and/or the resources being collected?

\subsection{Trails, Passes, and Travel Corridors}

Trails, mountain passes, and travel corridors all have unique rolls in the settlement of the San Luis Valley - Taos Plateau and in the connectivity of important places. Prehistoric and historic travel and trade routes connected settlements and allowed individuals access to important 
resources while mountain passes provided access in an out of the region. Today, many of those trails and travel corridors used by Native Americans; Spanish, Mexican, and American Explorers; fur-traders; and emigrants are still in use as major thoroughfares and serve as important tourist destinations in the form of historic trails and scenic byways. These places are discussed throughout Section 2.

\subsubsection{Data Needs and Research Avenues}

Church et al. (2007) identified data needs for trails and roads throughout Colorado, although many can be applied specifically to the San Luis Valley - Taos Plateau. These include the identification and/or documentation of the physical remains of trails and travel corridors segments and sites related to travel such as temporary camp sites, depots, and engineered structures such as bridges. Archaeological sites with diagnostic material to indicate temporal and/or cultural affiliation would provide important insights into the use and development of trails and travel corridors and their connection to larger travel networks.

Although Church et al.'s historic context is specifically geared towards archaeology, many of the suggested research avenues can be integrated into the present day in terms of how trails, passes, and corridors influence contemporary life. These include:

- Role of transportation in the growth and development of associated sites and nearby settlement.

- The degree of connection and integration of local or regional settlement and economy with the national/world system.

- Changes in the needs and limitations of modes of transportation.

\subsubsection{Research and Land Use Management Questions}

- What influence do travel routes have on the greater landscape and vice versa? Did preferred source materials act to spur certain trail use or did continued trail use lead to use of materials located along that trail?

- How did these travel routes influence trade patterns?

- How were settlement patterns influenced by the introduction of railroads and highways?

- What types of sites, material source locations, and/or semi-sedentary village sites are associated with known trail segments? How can these be used to identify unknown trail segments and locations of encampments and villages along trails that are known to have existed but were never documented?

- How did travel routes contribute to conflict and/or amicable socialization in the valley? 
- Based on the archaeological and geomorphological record, was trail use limited to certain times of the year?

- What additional information is likely to be obtained from archaeological sites within the travel corridors, along trails, or in passes? For example, will it be possible to determine who were the primary users of a trail/corridor at certain points in time based on the material culture found along it?

- Can the complete documentation of trails lead to the locations of encampments or villages that are known to have existed but were never found?

- How well does the written record reflect what is seen today along the route, as well as what is found in the archaeological record?

- How did trails, passes, and travel corridors change with changing modes of transportation (foot trail, horse trail, horse and carriage, locomotive, automobile)?

- If corridors are still in use, in what ways can they also be used for educational purposes or to help promote heritage tourism?

- To what degree do trails and roads developed/maintained by federal agencies contribute to recreational choices?

- How can the results of this cultural assessment help promote heritage tourism by identifying areas of recreational and cultural interest within travel corridors while still protecting resources?

- What is the appropriate physical and visual avoidance distance from trails and travel corridors that will mitigate impacts of development and human use?

- What types of mitigation can be applied to alleviate the effects of specific change agents on these corridors?

\subsection{Hispano Land Grants, Communal Use Patterns, and Places of Traditional Cultural Importance}

The San Luis Valley - Taos Plateau is a living cultural landscape with a vibrant Hispano community whose cultural traditions are closely integrated with the landscape. Many Hispano residents are descendants of families who held title to original land grants issued from Spain and Mexico. Early settlements were founded on the concept of shared space and communal land use that promoted a strong land and water conservation ethic that considered a community's longterm survival. Although urbanization, contemporary farming practices, and urban development have affected traditional life ways and shifted communal use patterns, the Hispano community continues to practice these communal concepts of shared resources and shared space. Long lot farming is still practiced throughout the valley, most commonly in San Luis. Land and water rights as well as protection of the land are very important issues to the Hispano community. 
Water is very important for both grazing and agriculture and wild plants throughout the valley have been historically and contemporarily used for food, fuel, and medicinal purposes (Higgins et al. 2013; Stoffle et al. 2008).

Hispano Land Grants, Communal Use Patterns, and Places of Traditional Cultural Importance were identified through a review of relevant literature, including Higgins et al. 2013 and Stoffle et al. 2008, as well as the Center for Land Grants website and local expert knowledge. Resources identified include land grant boundaries, historic homesteads, historic towns, plazas, acequia systems, sites associated with Spanish and Mexican history, and historic and contemporary communal collection areas. These places are important to Hispano cultural and religious practices and beliefs and are necessary for maintaining the community's cultural identity and are discussed throughout Section 2 of this document.

\subsubsection{Data Needs and Research Avenues}

One important need in regards to this cultural conservation element is the documentation of acequia systems throughout the valley. The popularity of center-pivot agriculture has been detrimental to acequia systems; however, these systems are still in use in some places. Some acequia systems have been documented; however, others have not. Researchers have a general idea of where these systems were once located, but an effort should be made to record both contemporary acequia systems and historic systems that have not yet been recorded. Documenting these systems will provide insights into different approaches to water distribution throughout the valley, communal use patterns, and settlement patterns. Archaeological sites that document early Hispano settlements are lacking in Colorado (see eligible historic properties cultural conservation element) and would also provide information on early use of land and communal use patterns.

While a number of sites of Hispano importance are known and have been recorded, there are likely others that exist. Consultation with Hispano residents of the San Luis Valley - Taos Plateau as well as representatives of the National Heritage Areas, whose purpose is to preserve living heritage resource, traditional life ways, communal use areas, and important historic resources should be documented.

Colorado History: A Context for Historical Archaeology (Church et al. 2007) is a historic context document that is specifically geared towards archaeology, however, many of the suggested research avenues presented in that document can be integrated into the study of contemporary life ways and how current life ways and community practices have been influenced by past events. Archaeological investigation and continued consultation can help to guide some of these research avenues, which include:

- The influence of the Homestead Act on settlements located on Land Grants;

- Differences in ethnic patterns of settlement and interaction of the people with their environment and each other; 
- Archaeological manifestations of mixed livestock and crop agriculture and the transition from mixed agriculture practices to monocrop agricultural practices and specialized ranching and farming;

- Different practices of recycling materials, including buildings, artifacts, features, and landscapes through time;

- Patterns of land and settlement abandonment through time;

- Different approaches to water distribution;

- Comparative information on socioeconomic status, ethnicity, health and diet, household composition, recreational pursuits, interaction with other culture, self-sufficiency, and participation in national markets; and

- The effect on the Hispano community of practicing subsistence-based agriculture while living in a cash-based economy.

\subsubsection{Research and Land Use Management Questions}

- How are cultural traditions, folklore, art, and agricultural practices represented within the current landscape? How can these be preserved in a way that is beneficial to the community while maintaining the integrity of the landscape?

- What was the influence of land grants on early settlements?

- What was the influence of the Homestead Act on settlements located in land grants and how does this manifest itself today?

- How do communal spaces within the landscape contribute to oral histories and contemporary community memory?

- What are the archaeological manifestations of the differences in communal land use?

- How has water influenced the historic and present land-use patterns within the ecoregion? How has this changed over time?

- What is the best approach for allowing development and open communal areas to coexist?

- What were/are the social impacts of technological change and availability on agricultural practices in the valley? (Church et al. 2007)

- What were/are the practices of recycling and adaptive reuse of artifacts, buildings and landscape features through time? (Church et al. 2007) 
- How can land-use patterns identified at the landscape level contribute to heritage tourism? What types of themes can be developed? Will they fit into already developed themes of the National Heritage Areas?

- Are there examples of historic and contemporary communal use patterns that can be used in heritage tourism initiatives? If so, how?

- How can the cultural landscape assessment contribute to initiatives envisioned by the National Heritage Areas to include interactive maps, publicly available resource locations, and oral history collection?

- How can the elements of the cultural landscape identified in the cultural assessment help tell the stories of the people of the region? Can these elements be incorporated into regional heritage tourism plans?

- The San Luis Valley - Taos Plateau is a broad cultural landscape. Are there specific cultural values that either support or oppose solar (or other development) within the region? Is there a community interest in solar development?

- Will solar development in the San Luis Valley significantly interfere with the traditional life practices of the people of the San Luis Valley - Taos Plateau or the resurgence of sustainable farming practices in the region?

- Will development in the region inhibit a feeling of pride in the landscape and/or constrain the cultural identity of those whose livelihoods are entwined with the landscape?

- Will solar development or other renewable or non-renewable energy development contribute positively or negatively to a self-sustaining community?

- What types of mitigation can be applied to alleviate the effects of specific change agents?

- What are acceptable forms of mitigation to cultural landscapes that are approved of by stakeholders?

\subsection{Paleontology}

This conservation element represents areas within the valley that have important paleontological research value. Only one major area of paleontological importance, a mammoth bone concentration near the De Tilla Gulch SEZ, was identified within the study area, although others areas, like the Sombrillo ACEC south of the study area in New Mexico, are known to occur just outside of the study area boundary.

The Alamosa Formation in the San Luis Valley has the potential to yield Pleistocene and Pliocene mammal species, as well as reptiles, birds, and fish, among other fossil types; however, there are only a few outcrops in the San Luis Valley (Lindsay 1983). A report by the U.S. Forest Service indicates that some exposures may occur near the San Luis Hills (Dyer 2009). In New 
Mexico, Pliocene and Pleistocene vertebrate fossils have been found in the Santa Fe Formation and the potential exists for significant fossil materials to be discovered throughout this formation in the study area. Quaternary deposits overlaying the Alamosa Formation have yielded vertebrate fossils, but they are typically fragmentary and of little research use for determining age (Lindsey 1983). Several mammoths have been found in the San Luis Valley at the Zapata Mammoth Site, Medano Mammoth Site (also known as Indian Spring), and Magna Site (Spero and Hoefer 1999). These sites have been of interest to archaeologists more so than paleontologists because of the potential for associations with Paleoindian artifacts. The bones that have been found to date have been highly fragmented and badly deteriorated (Spero and Hoefer 1999).

\subsubsection{Data Needs and Research Avenues}

Additional investigation into the Alamosa Formation in the Colorado portion of the ecoregion and the Santa Fe Formation in the New Mexico portion of the ecoregion may yield additional information regarding the paleoenvironment during the Pliocene and Pleistocene. The Quaternary deposits show some promise for mammoth and bison kill site assemblages associated with the Paleoindian period. Additional research to find areas with better bone preservation is needed, potentially including additional investigations at known sites to see if additional material may be present.

\subsubsection{Research and Land Use Management Questions}

- What are the environmental characteristics of the locations where mammoth remains are being found?

- What change agents are affecting the soils holding the fossil remains, and will heretofore undiscovered remains continue to degrade in situ?

- Are there other indicators, besides possibly Clovis and Folsom artifacts, of association between Paleoindian people and extinct Quaternary big game species in the San Luis Valley?

\subsection{Eligible Prehistoric Properties}

This cultural conservation element represents known prehistoric cultural resources that are listed or eligible for listing on the National Register of Historic Places (NRHP) or State Register. Most of these sites fall within the Biedell or La Jara archaeological districts and consist of open architectural sites, open camps, sheltered camps, open lithic sites, lithic scatters, ceramic scatters, rock art, and burials representing the Paleoindian through historic periods. A total of 1,939 prehistoric sites were evaluated for the regional cultural assessment.

\subsubsection{Data Needs and Research Avenues}

Although 1,939 listed or eligible prehistoric resources have been recorded in the valley, it is likely that many more resources exist. The San Luis Valley has the highest concentration of 
Paleoindian sites in Colorado. While the data that are available for Paleoindian settlements is rich, a temporal framework for the region as well as full-understanding of the Paleoindian use of the valley is lacking. Martorano et al. (1999) have recognized the need for continued research into Paleoindian Period exchange systems, technology, resource utilization, and social organization as well as the need to develop a temporal framework based on stratigraphic and radiocarbon studies.

Current information about the Archaic Stage indicates that the closed basin portion of the valley and San Juan Mountains were heavily utilized during the Archaic Period but little is known about this stage in the Sangre de Cristo Mountains and open basin portion of the valley (Martorano et al. 1999). Researchers have recognized the need for additional survey data in areas where information on the Archaic Period is lacking, as well as excavation data to provide information on plant and animal resources, feature types, stratigraphic relationships, radiocarbon dates, and paleoenvironmental data (Martorano et al. 1999).

Data needs for the Late Prehistoric Period are similar to the Paleoindian and Archaic Periods. Martorano et al. (1999) highlight the need for additional survey and analysis and interpretation of excavation data to provide insight into questions of subsistence strategies, population changes, and the transition between the Archaic to Late Prehistoric Period.

Archaeological survey is one of the biggest data needs in relation to eligible prehistoric resources. One of the main criticisms by Martorano et al. (1999) is that known prehistoric sites are poorly recorded and/or poorly researched; a more thorough analysis of existing data has been suggested.

\subsubsection{Research and Land Use Management Questions}

- What is the temporal and spatial relationship between culturally modified tree locations, brush structures, and prehistoric campsites?

- Continued preservation and protection of sites listed on or eligible for listing on the NRHP is a component of both the NRGNHA and the SdCNHA management plans. In what ways can NRHP-eligible and -listed sites provide opportunities for education, be used as interpretive resources, and/or foster a deeper understanding of pride and cultural identity?

- $\quad$ Some NRHP-eligible and -listed sites are tangible, visible components of the landscape. How can these sites contribute to community revitalization and/or be of use as components in a larger heritage tourism plan?

- What types of mitigation can be applied to alleviate the effects of specific change agents on these eligible and listed prehistoric properties? 
The following are from Martorano et al. (1999):

- What are the effects of climatic change on early adaptive patterns and cultural development?

- What is the role of geomorphological processes in the differential preservation and visibility of archaeology sites?

- What is the range and variability of assemblages within campsites and across landscapes and the implications these hold for understanding the social and technological organization of activities?

- What is the relationship between resource procurement, ritual practices, and patterns of group dispersal and aggregation?

- What are the archaeological signatures of human aggregation and the exchange/sharing of information, resources, and people within and between groups?

- What is the nature of gender roles and the archaeological signatures of women and children?

- What is the nature of high altitude Paleoindian adaptations?

- What are the origins, development, and relationships among groundstone, heated rock, and food preparation and storage technologies?

- What are the archeological correlates and effects of population increase?

- What is the variability in and determinants of late Pleistocene diet breadth?

- What is the nature of Archaic settlement systems in the San Luis Valley - Taos Plateau and surrounding mountain ranges?

- What is the range of variability represented by Paleoindian and Archaic strategies of resource procurement, mobility, and social interaction?

- What is the temporal sequence of prehistoric occupations in the study area?

- What are the local subsistence economies and how did they change over time?

- What is the geomorphic context of Archaic sites in the study area?

- What are the availability and distribution of lithic resources in the context region, and did the distribution of these resources affect settlement patterns? 
- What are the temporal context and function of the stone structures encountered in the context area and are Archaic housepits present in the region?

- How are Archaic sites structured and is variation in site structure apparent across time and geographic area?

- When did the transition between the Archaic and Late Prehistoric periods occur in the Rio Grande Basin?

- How and/or did the use of the bow and arrow and other traditionally used trait markers for this period affect subsistence strategies or relate to changes in the subsistence record in the Rio Grande Basin?

- Can cultural affiliations such as Ute and Apache be assigned to specific sites dating to this time period and if so, what artifacts or set of characteristic are the best indictors?

- Did indigenous groups or others live year-round in the Rio Grande Basin during the Late Prehistoric Period?

- Was horticulture practiced at any level within the Rio Grande Basin during the Late Prehistoric Period? Which areas would have been the best climatically to support horticultural practice?

- What does variation in tool stone utilization mean in relation to subsistence patterns and use of the Rio Grande Basin during the Late Prehistoric Period?

- Does any archaeological evidence suggest population increases at any time during the Late Prehistoric Period?

- How did Protohistoric period/Formative stage groups influence archaeology in the Rio Grande Basin?

- When did the transition to the Protohistoric period occur and were the Utes the primary inhabitants of the Basin at that time as suggested by historical resources?

\subsection{Eligible Historic Properties}

This cultural conservation element represents historic cultural resources that are listed on or are eligible for listing on the NRHP or State Register. These sites are mostly associated with military excursions, early settlements and homesteads, mining, and early urban development. A total of 1,141 historic properties were evaluated for the regional cultural assessment and include three National Historic Landmarks, a World Heritage Site, military forts, historic homes and buildings, cemeteries, homesteads, townsites, schools, mining cabins and complexes, rock alignments, farm buildings, agricultural and pasture lands, and campsites. 


\subsubsection{Data Needs and Research Avenues}

Although 1,141 listed or eligible historic resources have been recorded in the valley, it is likely that many more resources exist. For example, Church et al. (2007) indicate that information on early agricultural sites, settlements, and industries such as mining are underrepresented in Colorado’s archaeological site database. Early Hispano agricultural settlements, sheep grazing camps and arborglyphs, and mining sites from the region are especially underrepresented in the database, even though these types of sites are known to exist.

As with eligible prehistoric properties, one of the biggest data needs in relation to eligible historic resources is the need for archaeological survey. One reason archaeological sites may be underrepresented is that most archaeological investigation occurs as the result of cultural resource management work for private industry or urban development. Given the small-scale urban development within study area, geographic coverage of archaeological inquiry throughout the valley is limited and in many areas non-existent. While archaeological investigations are also the result of academic pursuits or State or Federal cultural programs, less than $8 \%$ of the study area has been surveyed for cultural resources. Individuals and state and federal representatives may know that resources exist but due to funding and staffing constraints, official documentation is lacking. One of the main criticisms by Church et al. (2007) is that known sites are poorly recorded and/or poorly researched. They suggest identifying consistent data recordation techniques for different resource types as well as making better use of archival data.

Church et al. (2007) identified a number of research avenues that can be applied throughout Colorado, but many can be applied specifically to the San Luis Valley - Taos Plateau. Many of these research themes were introduced in Section 3.4.1 related to the Hispanofocused cultural conservation element, but also apply to this broader historic property conservation element. These include:

- The influence of land grants on early settlements;

- The influence of the Homestead Act on settlements located on land grants;

- Differences in ethnic patterns of settlement and interaction with their environment and each other;

- Archaeological manifestations of mixed livestock and crop agriculture and the transition from mixed agriculture practices to monocrop agricultural practices and specialized ranching and farming;

- Different practices of recycling materials including buildings, artifacts, features, and landscapes through time;

- Patterns of land and settlement abandonment through time;

- Different approaches to water distribution; and 
- Comparative information on socioeconomic status, ethnicity, health and diet, household composition, recreational pursuits, compatibility with the dominant culture, selfsufficiency, and participation in national markets.

As planning efforts expand throughout the region, research and recordation of historic sites and structures can inform and be informed by the larger cultural landscape. Detailed characterization of the properties is important, such as whether sites represent single households, multiple households (e.g., boarding houses and apartment complexes), larger settlements, institutional sites (e.g., schools, churches), agricultural sites, businesses, or industrial sites. The detailed attribute data recorded for each property provide important information to help us understand how individuals and communities socially interacted and negotiated these landscapes over time. The archaeological and historic record can provide a bigger picture of what happened when people of different ethnic backgrounds lived together, how their everyday lives were influenced by government, industry, and modernization, and how traditional practices have been modified to accommodate a changing landscape. Data of this nature can help identify opportunities for education and interpretive resources, and foster a deeper understanding of pride and cultural identity within the community - key components of the NRGNHA and SdCNHA missions.

\subsubsection{Research and Land Use Management Questions}

- How is the influence of land grants on early settlements manifested in material culture?

- How is the influence of the Homestead Act on settlements located in land grants manifested in material culture?

- What are the archaeological manifestations of mixed livestock and crop agriculture and the transition from mixed agricultural practices to monocrop agricultural practice and specialized ranching and farming?

- What are the different practices of recycling materials, including buildings, artifacts, features, and landscapes, through time?

- What is the difference in settlement patterns between settlers of different ethnic and/or religious backgrounds?

- Where are the traditional sheep camps?

- What families continue generational sheep grazing? Are there elders that can offer oral histories of past grazing practices?

- Where are the routes/stock driveways that were used to bring sheep from the lower elevations to the upper elevations? Can these be mapped in GIS, supplemented by oral histories? 
- Where are the aspen groves of undocumented arborglyphs that may be associated with the stock driveways?

- What are/were the ethnicities of the sheepherders? Can we garner identity and time of use from the arborglyphs?

- How do change agents such as disease transmission to bighorn sheep and the market affect these historic traditions?

- How do change agents, such as climate change and tree disease, impact undocumented arborglyphs on aspen trees?

- How is the herding tradition changing as wool products are replaced by synthetic fibers and imports?

- What are the patterns of land abandonment through time?

- What are the different approaches of water distribution through time?

- What are the archaeological manifestations of socioeconomic status, health and diet, household consumption, and recreational pursuits? How can this information be used to determine differences in settlement patterns and social behavior between settlers of different ethnic and/or religious backgrounds?

- What types of mitigation can be applied to alleviate the effects of specific change agents on eligible historic properties?

- Are mining sites being affected by change agents, or are these site types relatively stable because of their locations at higher elevations? What are the current risks to these sites? 


\section{METHODOLOGY}

The San Luis Valley - Taos Plateau Landscape Assessment is the first BLM REA-type analysis to incorporate an assessment of the cultural landscape. Because the cultural assessment is meant to be integrated with the ecological and visual landscape assessments, the San Luis Valley - Taos Plateau cultural methodology was conducted using a similar methodology to the one that was used for the Landscape Assessment (Walston et al. 2016). As a result, much of the methodology is not repeated here; the reader is referred to the Landscape Assessment.

\subsection{Data Collection and Management}

\subsubsection{Data Collection}

One of the tenets of the REAs is that data collection is minimized and best available digital data sets are used. For the purposes of this cultural assessment, that "rapid" assessment rule did not provide a realistic path for achieving a usable result, primarily because much of the available information, while extensive, was in narrative form. A digital data set that was readily available included spatial and tabular data on known cultural resources identified through archaeological surveys. These data, including location, condition, cultural affiliation and eligibility status, were collected through the State Historic Preservation Offices in Colorado and New Mexico, specifically through the Colorado Historical Society and the Archaeological Records Management System - New Mexico Cultural Resources System (ARMS-NMCRIS) in the New Mexico Historic Preservation Division, respectively ${ }^{1}$. Attribute data describing individual archaeological sites were not directly comparable across the two systems because of different data categorization schemes and reporting instructions for researchers, as well as inconsistent completion of requested data fields (e.g., many descriptive fields were left blank). These incompatibilities were addressed by limiting the specificity with which some sites could be assigned a cultural conservation element. This is one reason for the catchall conservation elements of prehistoric and historic properties - in many cases there was not much more description than that, but since we were only categorizing eligible properties we typically at least had some aspect of temporal affiliation. Additional digital data were available through the National Park Service on National Historic Trails, National Historic Landmarks, and National Register of Historic Places, and also from BLM and USFS on specific agency lands and their special designations.

Narrative data of interest were collected through a literature review of regional contexts, technical documents, ethnographies, and management plans. In addition, solicitation of local expert knowledge, including university professors and BLM, NPS, USFWS, and USFS staff provided data of interest. A list of the major documents that were consulted is provided below in Table 4-1, but many additional sources are identified in the references. Where possible, the narrative data were converted to spatial data from available location descriptions and best professional judgment.

\footnotetext{
${ }^{1}$ Data are of variable quality and may or may not include information about site type, eligibility status, or site condition.
} 
Table 4-1. Primary Documents Consulted for Narrative Data

\begin{tabular}{llc}
\hline Title & Author & Year \\
\hline $\begin{array}{l}\text { Seinanyédi: An Ethnographic Overview of Great } \\
\text { Sand Dunes National Park and Preserve }\end{array}$ & White, David & 2005 \\
\hline $\begin{array}{l}\text { Cultural Continuity: An Ethnographic Study Related } \\
\text { to Potential Solar Energy Development in the San } \\
\text { Luis Valley, Colorado }\end{array}$ & Higgins et al. & 2013 \\
\hline $\begin{array}{l}\text { Ethnohistoric and Ethnographic Assessment of } \\
\text { Contemporary Communities along the Old Spanish } \\
\text { Trail }\end{array}$ & Stoffle et al. & 2008 \\
\hline $\begin{array}{l}\text { Sangre de Cristo National Heritage Area } \\
\text { Management Plan }\end{array}$ & \\
\hline $\begin{array}{l}\text { The Northern Rio Grande National Heritage Area } \\
\text { Management Plan }\end{array}$ & \\
\hline $\begin{array}{l}\text { Colorado Prehistory: A Context for the Rio Grande } \\
\text { Basin }\end{array}$ & Martorano et al. & 2013 \\
\hline $\begin{array}{l}\text { Colorado History: A Context for Historic } \\
\text { Archaeology }\end{array}$ & Church et al. & 2007 \\
\hline Solar PEIS for Six Southwestern States & BLM and DOE & 2012 \\
\hline Colorado Southern Frontier Historic Context & $\begin{array}{l}\text { Carrol Joe Carter } \\
\text { and Steven F. }\end{array}$ & 1984 \\
& Mehls & \\
\hline
\end{tabular}

Much of the valley is under private ownership and, and as previously stated, the dynamics between the people and the land are such that many individuals are still dependent on the land for their survival and/or are connected to the land in such a way that it influences their well-being. The San Luis Valley - Taos Plateau is an area that is rich in history, environment, recreational opportunities, and social and community activities that are deeply connected to the land for both Native American and Hispano communities, as well as for other long-term residents. For this reason, it is important to consider the concerns of the local populations with historic and contemporary ties to the valley. To this end, three ethnographies were reviewed as part of the data collection process (see Table 4-1).

Although these ethnographies were conducted for projects unrelated to the cultural heritage values and risk assessment, they were conducted as part of development and land-use planning efforts within the San Luis Valley - Taos Plateau and contain valuable information regarding the importance of cultural resources amongst Native American and Hispano communities. As part of a BLM initiative in support of solar energy development, members of both Hispano and Native American communities were interviewed in regards to potential solar energy development in the San Luis Valley - Taos Plateau. Their views are expressed in Cultural Continuity: An Ethnographic Study Related to Potential Solar Energy Development in the San Luis Valley, Colorado (Higgins et al. 2013), and while taken into consideration throughout the cultural assessment process, are not reiterated here. Locations within the study area identified in these documents were converted to spatial data as points or polygons depending on the type of location identified. Also, if certain natural features were recognized as 
important (e.g., wetlands, pinyon-juniper stands), they also were delineated spatially using existing GIS environmental data layers (vegetation, hydrology, elevation, etc.) as available through the Landscape Assessment or through digitizing available sources of non-digital data that could be geo-referenced or checked for accuracy by other means (such as terrain).

\subsubsection{Data Management}

The majority of data considered for the Landscape Assessment were handled in accordance with BLM's data management protocols for REAs. For more information on datasets used as inputs in analyses for the San Luis Valley - Taos Plateau Landscape Assessment, data sets generated during evaluation of input data, and model output the reader is directed to Section 3.1 and Appendix C of Walston et al. 2016. Many of the same base environmental data layers were also used in the cultural assessment; however, because of sensitivities of the locational data, both archaeological and ethnographic, the cultural GIS data used in this assessment will not be publicly available. A complete inventory of the cultural data sets accompanies the data delivered to the BLM.

Consistent with the Landscape Assessment, the default reporting unit size selected for the cultural assessment is $1 \mathrm{~km}^{2}$. The geoprocessing framework to evaluate the data involves ArcGIS tools and scripts. A polygon grid system is created using the Create Fishnet tool, found in ESRI's ArcToolbox, as the template for all of the derived data models described in Section 4.2. The grid is what allows the analyst to aggregate input datasets into meaningful results. The San Luis Valley - Taos Plateau study area polygon boundary is used as the Template Extent, and cell size width and height are set to 1,000 m each. Although ArcGIS ModelBuilder was not used due to the pilot nature of this project, it is possible to convert the modeling process, as described below in Section 4.2, to that format in the future to allow for systematic repetition of the process as new data are made available.

\subsection{Models}

A geo-process model was developed to graphically display the data used and the GIS analysis implemented to analyze cultural conservation elements (Figure 4-1a and b). Figure 4-1a shows how cultural resources data (inputs, as shown in red text in the light blue ovals on the left) were used to develop cultural conservation elements and how those cultural conservation elements were analyzed to reach one of three cultural resources of concern model outputs: union (maximum extent), coincidence (overlap), and scoring (assigned values based on priorities). These three output models are described in Section 4.2.1. Figure 4-1b shows a number of derived data models that extend beyond what is provided in the Landscape Assessment. These models were derived to illustrate how the cultural assessment could be implemented in a land management setting. One component of Figure 4-1b shows the change agent model outputs as inputs generating a risk model output. A second component is the cultural resources of concern model outputs as inputs, along with uncertainty/research potential and viewsheds model outputs, to capture landscape-level indicators of cultural values. Both the risk model output and the cultural value output are combined to achieve an ultimate mitigation potential output (Sections 4.2.3 through 4.2.6). 


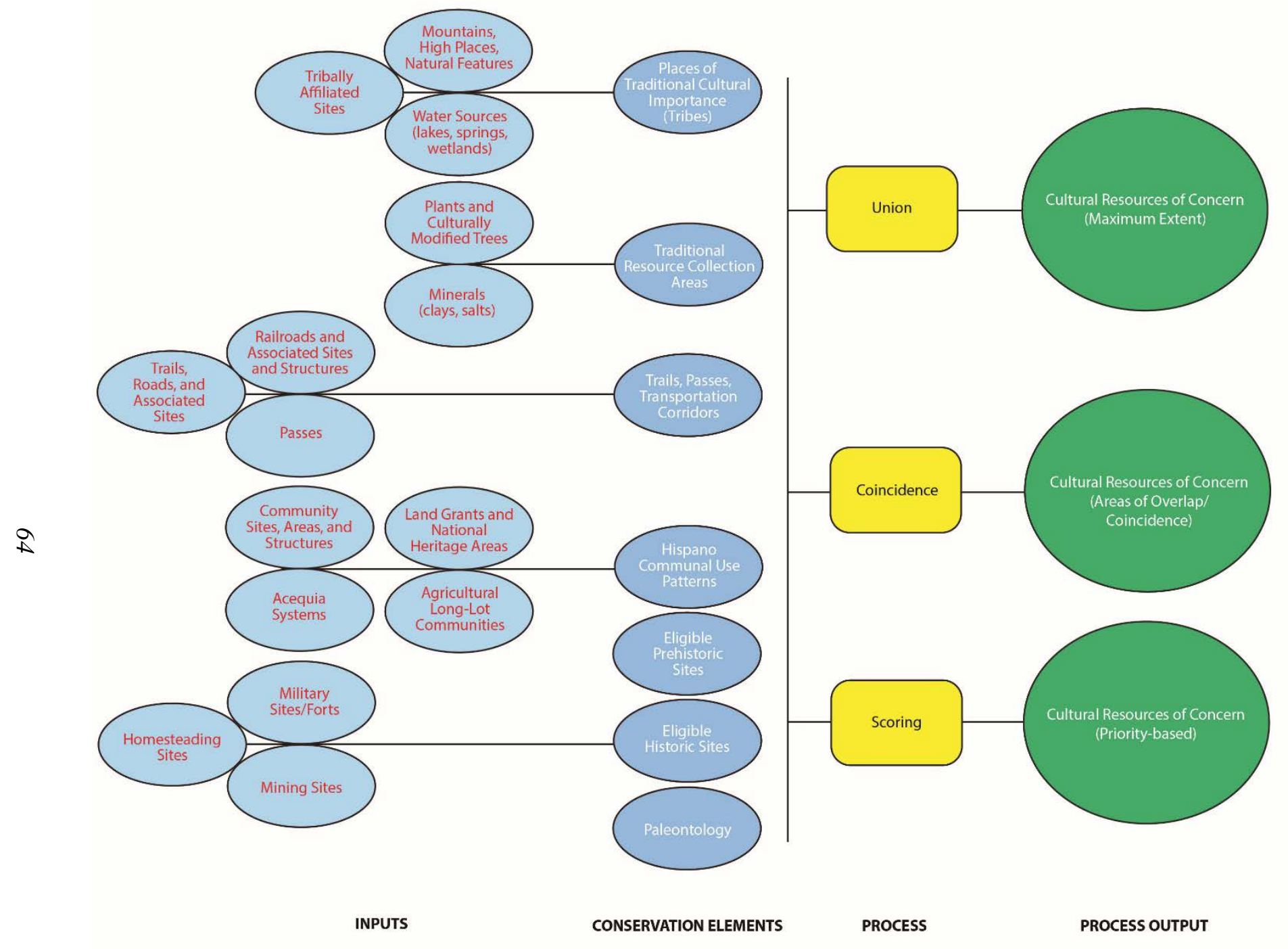

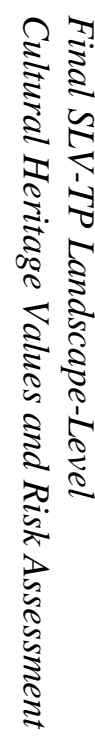

Figure 4-1a. Geo-process Model - Part 1 


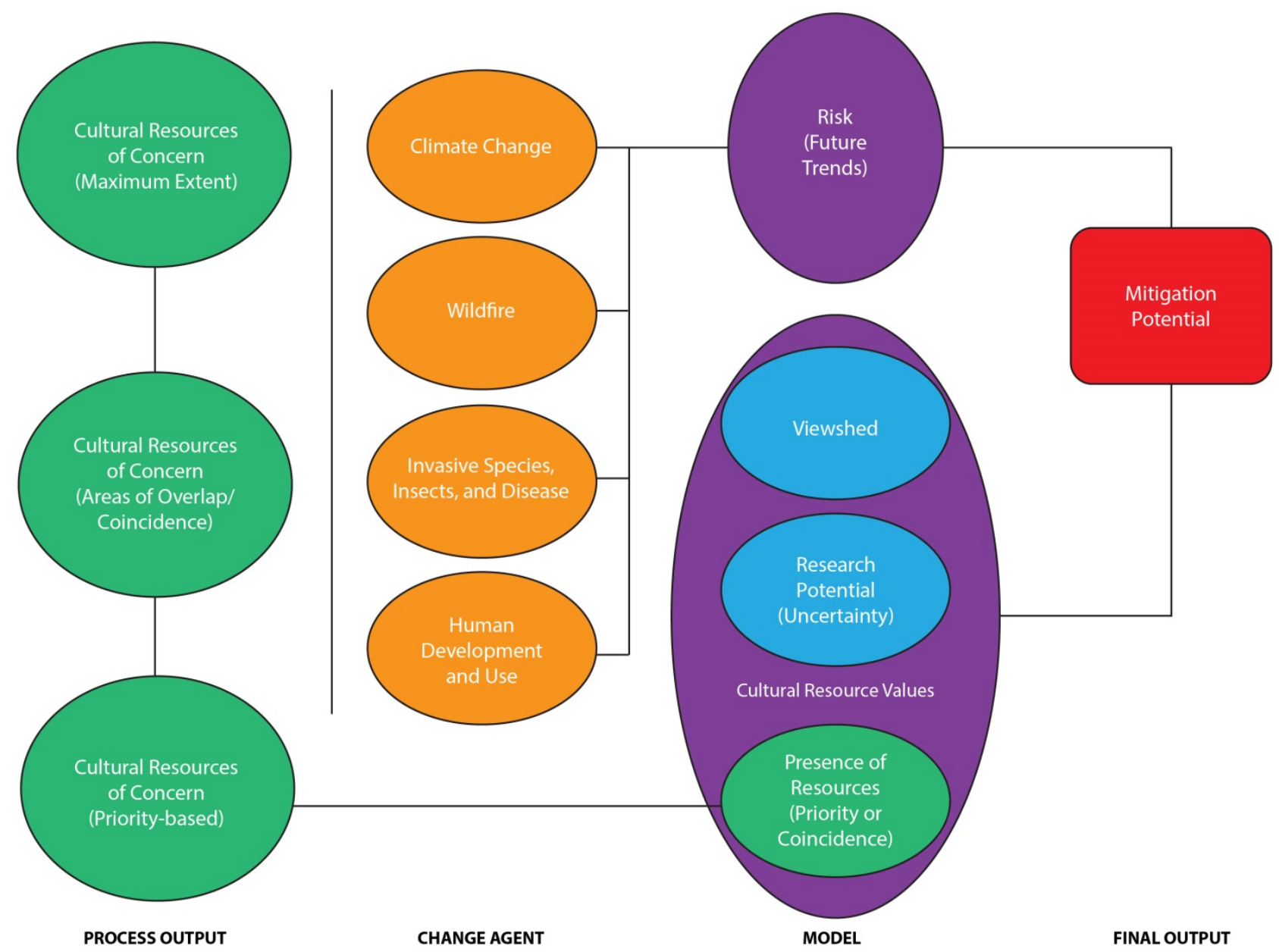

D

PROCESS OUTPUT

CHANGE AGENT

MODEL

FINAL OUTPUT

Figure 4-1b. Geo-process Model - Part 2 
Models related specifically to the change agents (human development, climate change, wildfire, and invasive species, insects, and disease), other than risk, are not described in this document. Detailed information on the change agent models is available in the Landscape Assessment (Walston et al. 2016). No modifications to those specific models were made for the cultural analysis.

\subsubsection{Cultural Resources of Concern}

Each of the following output models gauges the value of the cultural conservation elements in slightly different ways. This is unique to the cultural assessment and was not included as part of the Landscape Assessment for ecological resources.

\subsubsection{Cultural Resources of Concern Union Model}

The union model characterizes the combined maximum extent of all of the known cultural resources within the San Luis Valley - Taos Plateau boundary (Figure 4-2). In GIS terminology, a union is an analytical process that combines features of two or more map layers into one composite layer. In other words, resources within each cultural conservation element are spatially displayed as a single data layer; overlapping resources are not discernible. This model serves to spatially display the extent of cultural conservation elements across the study area and identify areas where cultural resources have not been identified. The results of this model will aid in directing future research endeavors. In Figure 4-2, the National Heritage Areas and the non-adjudicated land grants were not included in the shading because they would obscure many of the resources present in the region due to their broad extent; however, the outline of the National Heritage Areas is depicted and the full set of land grants are included in other figures. The National Heritage Areas and land grants are considered throughout this document as important, defined areas of cultural value.

\subsubsection{Cultural Resources of Concern Coincidence Model}

The coincidence model characterizes the areas of cultural conservation element overlap (Figures 4-3 and 4-4). This model counts resources or conservation elements in each $1 \mathrm{~km}$ grid cell within the GIS to identify areas of highest density of important cultural resources. This model appears to be the most efficient method for identifying the value and importance of areas of significance based on resource density and potentially areas for future mitigation and/or conservation actions.

The coincidence model was completed using the Spatial Join function in ArcGIS Desktop to join the feature inputs to the $1 \mathrm{~km}$ polygon grid. The features of interest (either resources or conservation elements) are appended into one feature class and joined to the grid ${ }^{2}$. Each cell is assigned a total score value based on adding the number of cultural conservation elements present. This was also completed for each individual resource identified within each cultural

2 This is accomplished using the Spatial Join tool by right-clicking the polygon grid and choosing Join, as opposed to accessing the Spatial Join tool in ArcToolbox. It is important to note that the ArcToolbox version functions differently and does not provide all of the necessary summary statistics. 


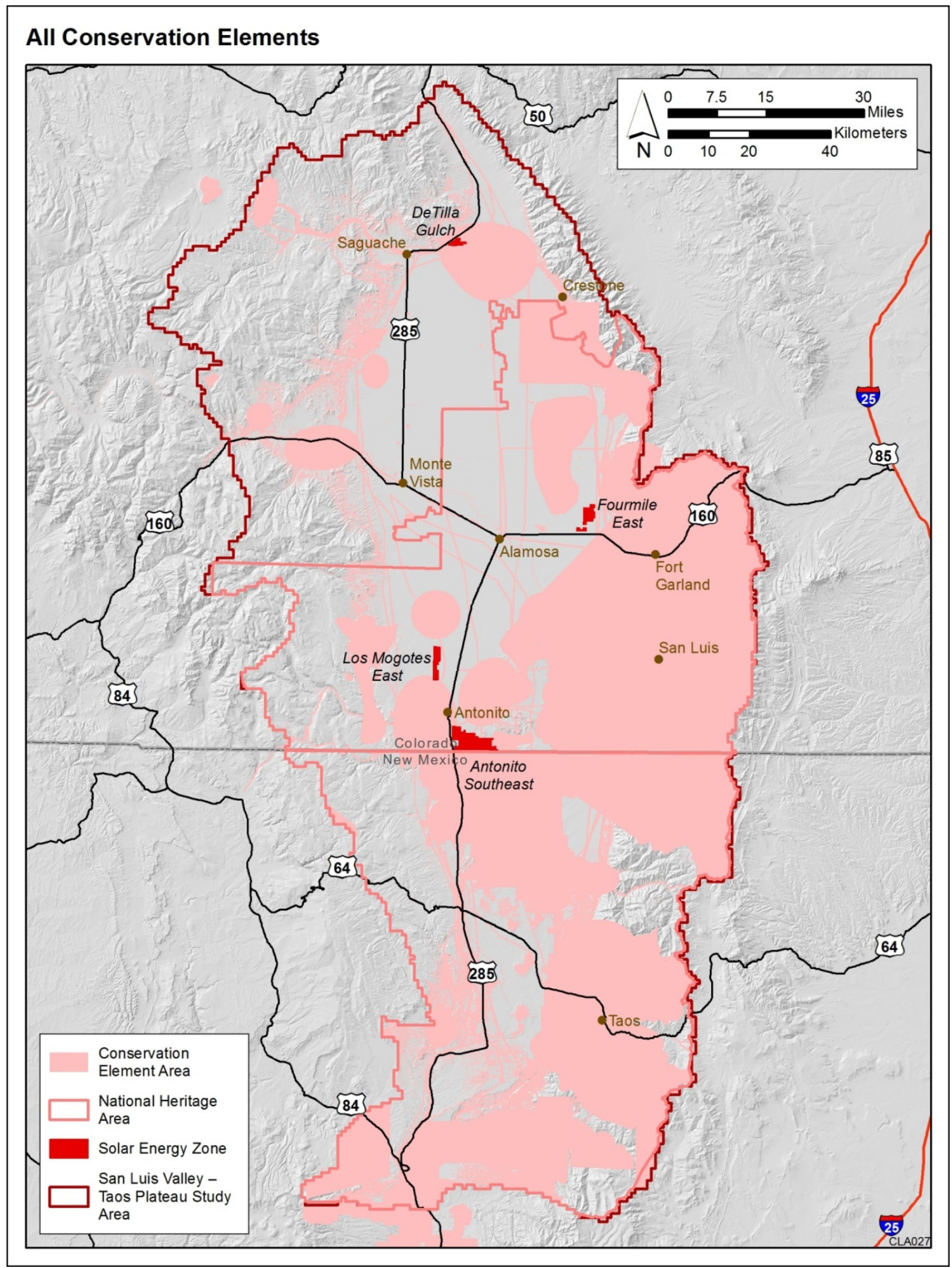

Figure 4-2. Cultural Resources of Concern Union Model 


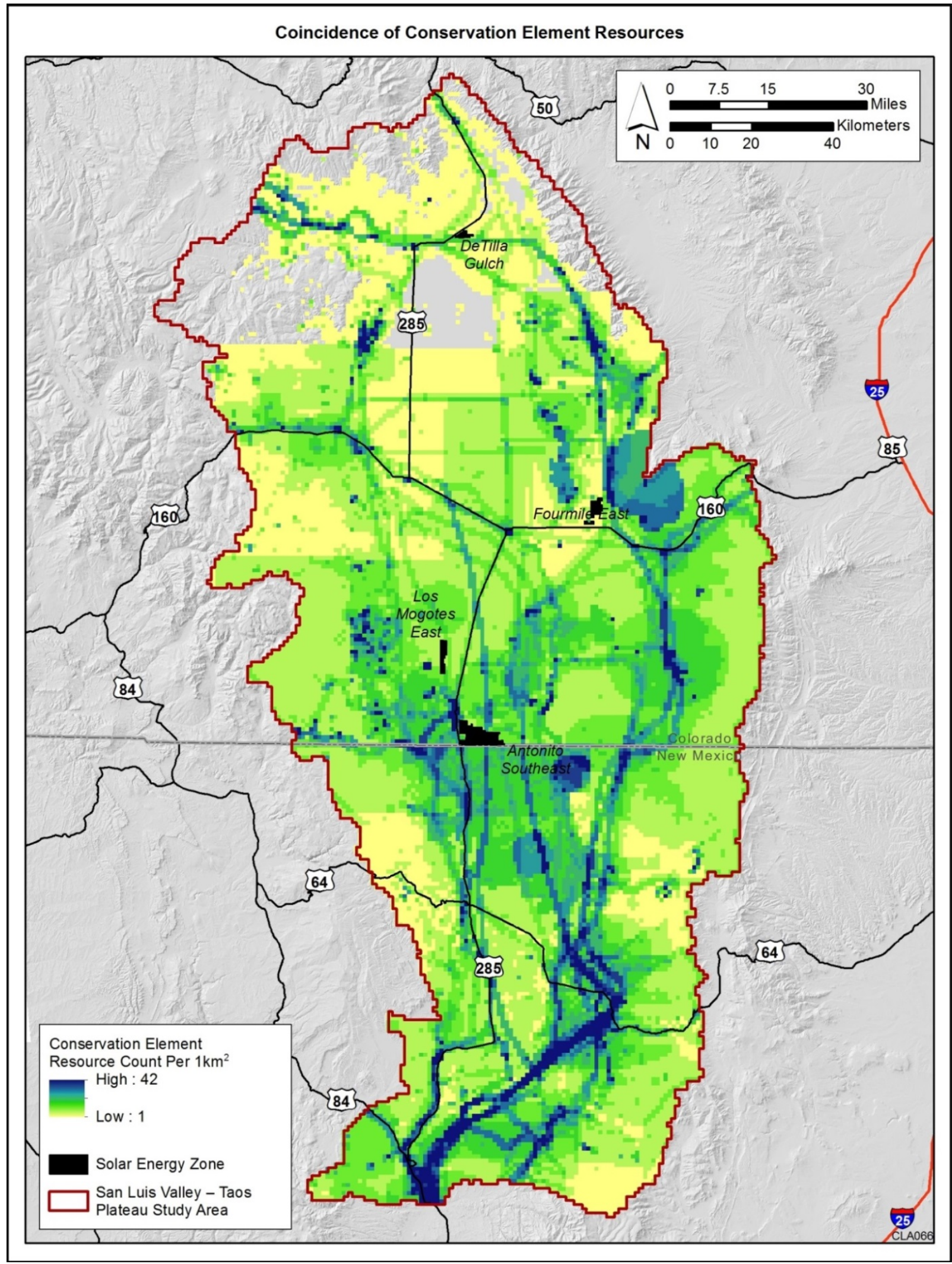

Figure 4-3. Cultural Resources of Concern Coincidence Model (Resources) 


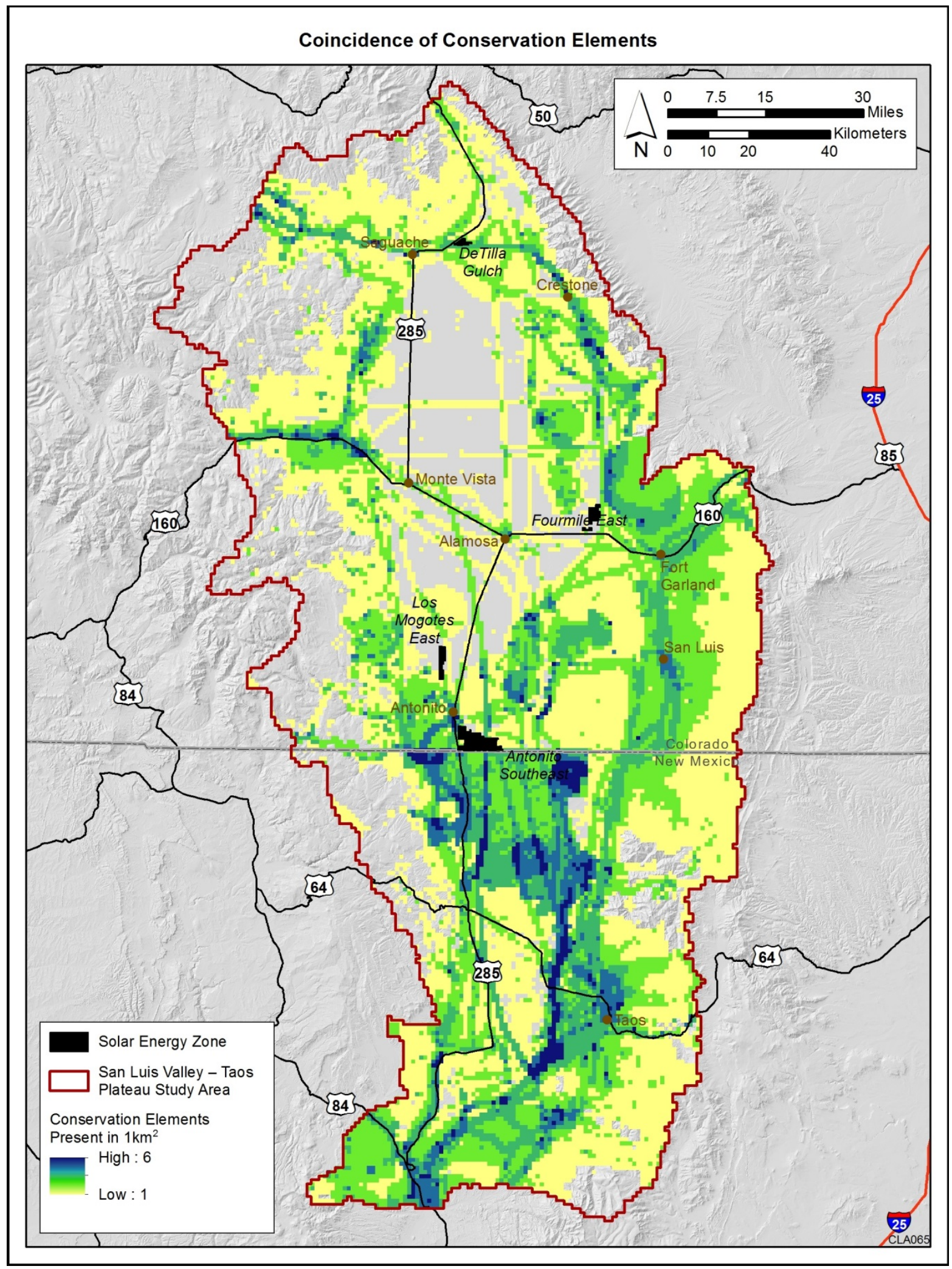

Figure 4-4. Cultural Resources of Concern Coincidence Model (Conservation Elements) 
conservation element. Figure 4-3 shows the coincidence or density of individual resources within each $1 \mathrm{~km}$ grid cell and Figure 4-4 shows the coincidence of the 7 cultural conservation elements.

\subsubsection{Cultural Resources of Concern Scoring Model}

The scoring model characterizes the relative importance of each resource within each cultural conservation element based on assigned scores (Figure 4-5). Individual resources were evaluated for their contribution to one of four categories: importance, integrity, intactness, and ability to answer research questions related to the cultural conservation element. Importance refers to the level of importance or significance of a resource to stakeholders based on available references, expert knowledge of agency staff, and comments received in the past from stakeholders. Integrity in this case refers to integrity of meaning and function of the resource based on available references, expert knowledge of use, and prior comments. In other words, is the location still being used in the same way and does it hold the same traditional meaning as it did in the past? Intactness is the condition of the resource or level of disturbance based on SHPO data and expert knowledge. Intactness could potentially also be informed by the human development change agent model (current condition), but in this case the score was limited to field-based knowledge or assigned a default score for unknown. The score for ability to answer research questions also includes ability to contribute new and significant information and is based on the regional research design questions provided in Section 3, SHPO data, and expert knowledge. Resources were assigned a score between 0 and 0.25 in each of the four categories by the core team. A score of 0.125 was considered a default in the absence of sufficient information on a particular category. If an individual did not feel comfortable evaluating a resource or assigning a score for a particular category no score was assigned by that individual. Scores were averaged for each category based on the number of individuals who assigned a score. In many cases, scores across resources and within categories were similar; however there were some anomalies. In these cases, a 'reasonable' score was assigned taking into account the score of the individual who is the better expert on the resource and averaged accordingly. A final score was derived for each resource by adding the averages of each category within each grid cell. Final scores ranged on a scale from 0-1.

This model is intended to identify priority areas of significance through evaluating different aspects of each resource. This model takes into account that cultural resources have many variables that make them important and that different groups may value different aspects of the resource. However, in application it was found that many individuals were uncomfortable assigning a score to cultural resources, especially those that others may consider sacred. In other cases, the experts did not agree on the scores that were given by each other and it was difficult to arrive at an appropriate score. In future updates it is recommended that BLM explore additional scoring alternatives, in particular, ways to solicit direct stakeholder input on resources as a preferred approach over the input of a limited agency team.

\subsubsection{Change Agents and Cultural Landscape Condition Model}

Change agent modeling for cultural resources was performed in much the same way as for the Landscape Assessment (see Section 3 of Walston et al. 2016). Each cultural conservation 


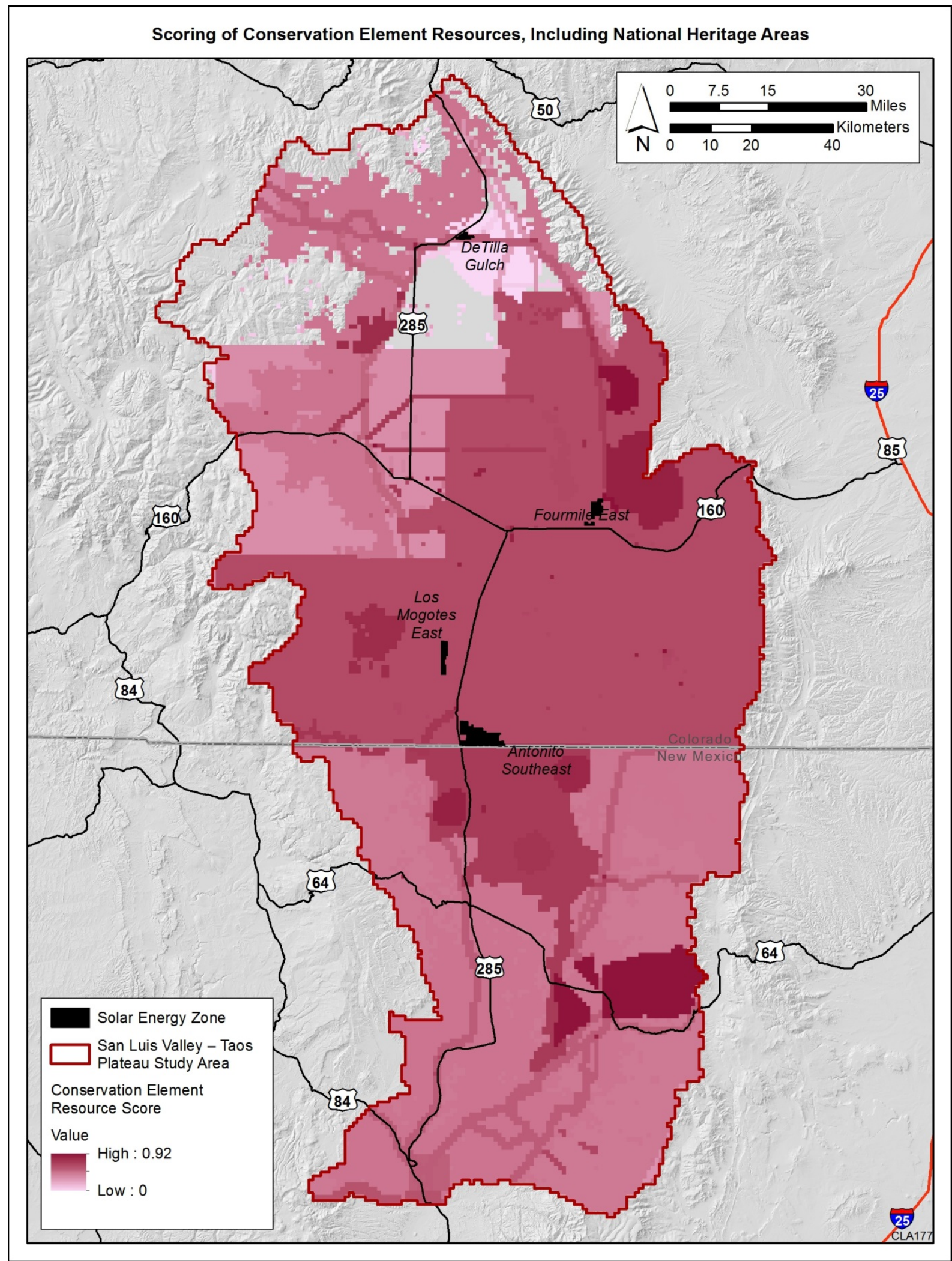

Figure 4-5. Cultural Resources of Concern Scoring Model 
element was evaluated for whether each of the change agents has the potential to affect that resource. For the most part all of the change agents likely affect all of the cultural conservation elements, with the exception of the paleontology and the trails and transportation conservation elements, in which changes in invasive species is not considered to affect the resources. In addition, wildfire is considered not likely to affect paleontology.

An additional difference is that the derived models for landscape intactness used in the ecological assessment (methodology described in Section 3.2.3 of the Landscape Assessment, Walston et al. 2016) are not applicable for use in the cultural heritage values and risk assessment. This is because the parameters for landscape intactness (or naturalness) do not tell a complete story about intactness of a cultural landscape, especially when that story is tied to some sort of landscape modification. Instead, using the same methodology and same underlying data set on human development, a number of parameters were adjusted to be more relevant to cultural resources (i.e., to create an image of cultural landscape condition based on degree of influence of a development-related activity on a cultural resource; see Tables 4-2 and 4-3). For example, presence of a dirt road may adversely affect resources by creating access that may lead to inadvertent or purposeful damage to a site. There is a distance at which that effect may be at its highest and then decline with increasing distance. These types of variables were taken into account to illustrate current and future cultural landscape condition based on development activities shown in Figure 4-6. The darkest blue areas are the areas of greatest development and therefore the poorest cultural landscape condition (assuming that the development identified in the model is not preserving older or traditional forms of past human development that, if present, are at risk). The darkest green indicates areas of least disturbance from human activities.

\subsubsection{Archaeological Research Potential Model}

In addition to the presence of cultural conservation elements, BLM and Argonne also consider the lack of cultural resource surveys in the study area, the potential for additional resources to be present, and how these factors affect the current understanding of cultural resource distributions. This is unique to the cultural assessment and is not included in the Landscape Assessment. An archaeological research potential model (Figure 4-7) was created to identify areas with future research potential taking into account some of the uncertainty due to lack of survey and research and also considering the areas of known higher resource potential, such as along water courses. The intent of the model is not to predict where resources are located but to identify areas that might offer opportunities for research, conservation, and mitigation in the future.

The archaeological research potential model involved assigning scores to various cultural polygon feature classes (e.g., survey polygons), creating a composite feature class, and then spatially joining the composite feature class to the polygon grid system to calculate the sum of all scores per feature class present within each $1 \mathrm{~km}$ grid cell. Scores assigned to each input feature class are provided in Table 4-4. Total scores do not exceed 1, but because multiple sites may be present in a $1 \mathrm{~km}^{2}$ area, it is possible to have all of the feature classes present in one grid cell. In Figure 4-7, the darkest brown areas are the highest scores based on all of the feature classes; note though that the values have been normalized for input into another model discussed in Section 4.2.5 so the legend indicates the values are 0 to 0.25 rather than 0 to 1. 
Table 4-2. Current Cultural Landscape Condition Model ${ }^{1}$

\begin{tabular}{|c|c|c|c|c|}
\hline Human Land Use or Impact Factor & $\begin{array}{c}\text { Site } \\
\text { Impact } \\
\text { Score }^{2} \\
\end{array}$ & $\begin{array}{l}\text { Presumed } \\
\text { Relative } \\
\text { Stress }^{3} \\
\end{array}$ & $\begin{array}{c}\text { Distance of } \\
\text { Influence } \\
(\mathbf{m})^{4} \\
\end{array}$ & Function $^{5}$ \\
\hline \multicolumn{5}{|l|}{ Transportation } \\
\hline Trails/Unpaved Access Roads & 0.1 & High & 800 & logistic \\
\hline Secondary Paved/Unpaved Roads & 0.3 & Medium & 400 & logistic \\
\hline Primary Paved Roads & 0.5 & Low & 200 & linear \\
\hline \multicolumn{5}{|l|}{ Urban and Industrial Development } \\
\hline Low Density Development & 0.5 & Medium & 500 & logistic \\
\hline Medium Density Development & 0.35 & High & 2000 & logistic \\
\hline High Density Development & 0.015 & High & 2000 & logistic \\
\hline Powerlines /Transmission Lines & 0.6 & Low & 200 & linear \\
\hline Mines and Oil/Gas Well Pad Locations & 0.3 & High & 500 & logistic \\
\hline Urban Polygons (BLM and U.S. Census Bureau) & 0.015 & High & 2000 & logistic \\
\hline High Impervious Surfaces (NLCD Imperv $>40$ ) & 0.3 & High & 500 & exponential \\
\hline \multicolumn{5}{|l|}{ Managed and Modified Land Cover } \\
\hline $\begin{array}{l}\text { Low Agriculture and Invasives (ruderal forest, recently } \\
\text { burned, recently logged, etc.) }\end{array}$ & 0.7 & Low & 500 & linear \\
\hline Pasture (landcover) & 0.5 & Medium & 1000 & linear \\
\hline Grazing Allotment Polygons & 0.4 & Medium & 1000 & exponential \\
\hline Introduced Vegetation & 0.6 & Low & 500 & linear \\
\hline Cultivated Agriculture & 0.5 & Medium & 2000 & linear \\
\hline \multicolumn{5}{|c|}{ 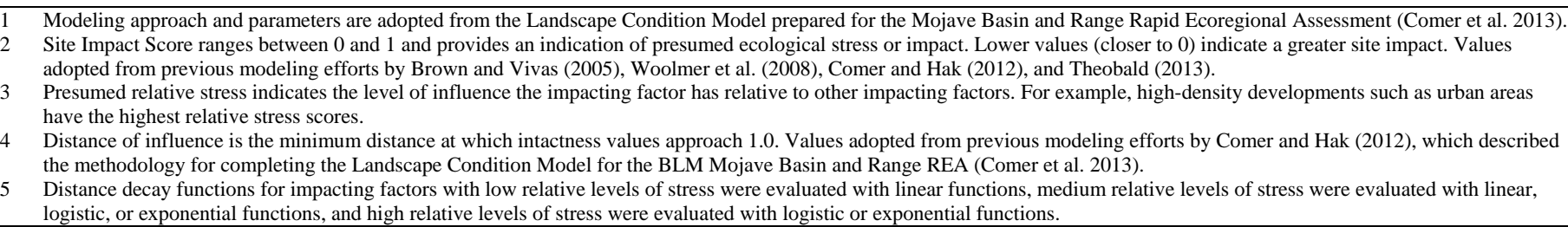 } \\
\hline
\end{tabular}


Table 4-3. Future Cultural Landscape Condition Model ${ }^{1}$

\begin{tabular}{|c|c|c|c|c|}
\hline Human Land Use or Impact Factor & $\begin{array}{c}\text { Site } \\
\text { Impact } \\
\text { Score }^{2} \\
\end{array}$ & $\begin{array}{c}\text { Presumed } \\
\text { Relative } \\
\text { Stress }^{3} \\
\end{array}$ & $\begin{array}{c}\text { Distance of } \\
\text { Influence } \\
(\mathbf{m})^{4}\end{array}$ & Function $^{5}$ \\
\hline Suburban Development Risk (Theobald), Value $=3$ & 0.2 & High & 2000 & Logistic \\
\hline Exurban Development Risk (Theobald), Value $=2$ & 0.3 & Medium-High & 2000 & Logistic \\
\hline Rural Development Risk (Theobald), Value $=1$ & 0.1 & Medium & 1000 & Linear \\
\hline High Urban WUI (WUI = 2) & 0.2 & High & 2000 & Logistic \\
\hline Low WUI (WUI = 1) & 0.3 & Low & 1000 & Linear \\
\hline Future Energy Development - SEZs & 0.1 & High & 2000 & Exponential \\
\hline Potential Oil and Gas Development (Copeland, Value > 15) & 0.3 & Medium & 1000 & linear \\
\hline 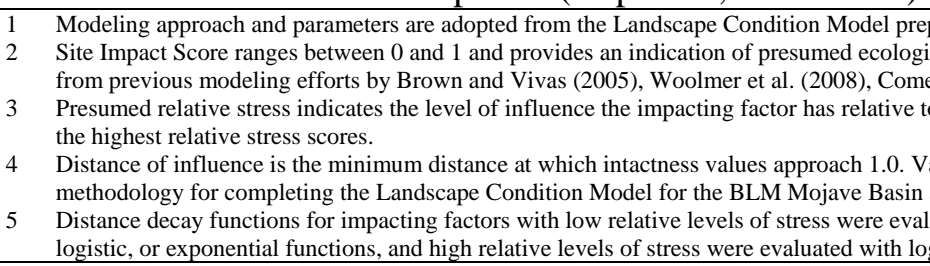 & $\begin{array}{l}\text { or the Mojav } \\
\text { iss or impact } \\
\text { Hak (2012), } \\
\text { impacting fa } \\
\text { dopted from } \\
\text { nge REA (C } \\
\text { vith linear fu } \\
\text { rexponentia }\end{array}$ & $\begin{array}{l}\text { asin and Range Rapid Ecc } \\
\text { wwer values (closer to 0) ir } \\
\text { Theobald (2013). } \\
\text { rs. For example, high-den } \\
\text { vious modeling efforts by } \\
\text { er et al. 2013). } \\
\text { ions, medium relative leve } \\
\text { nctions. }\end{array}$ & $\begin{array}{l}\text { er and Hak (2012 } \\
\text { stress were evalu }\end{array}$ & $\begin{array}{l}\text { er et al. 2013). } \\
\text { Values adopted } \\
\text { rban areas have } \\
\text { ich described the } \\
\text { vith linear, }\end{array}$ \\
\hline
\end{tabular}




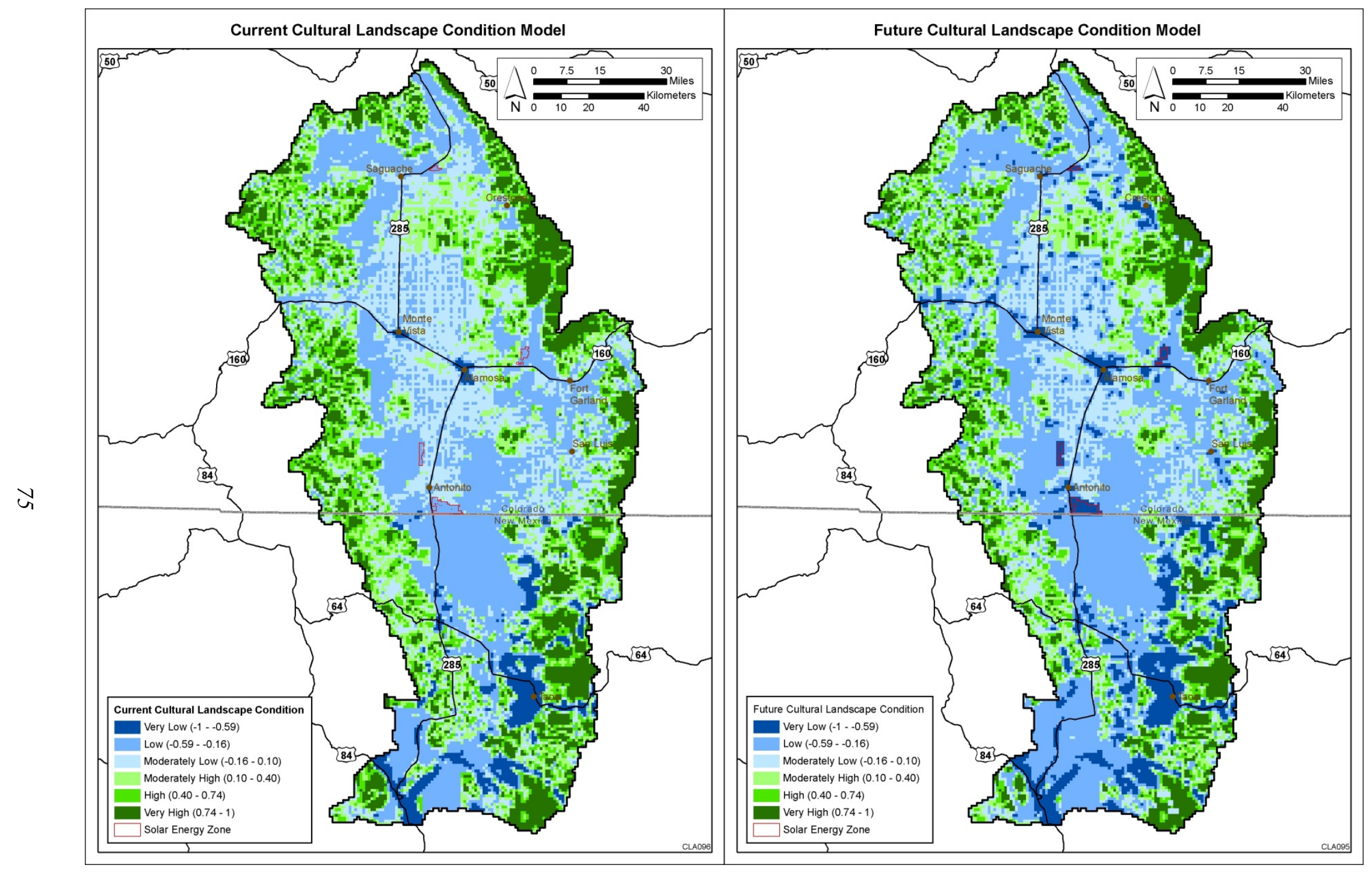

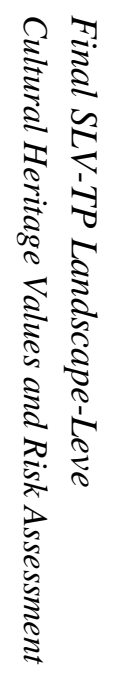

Figure 4-6. Current and Future Cultural Landscape Condition in the San Luis Valley - Taos Plateau 


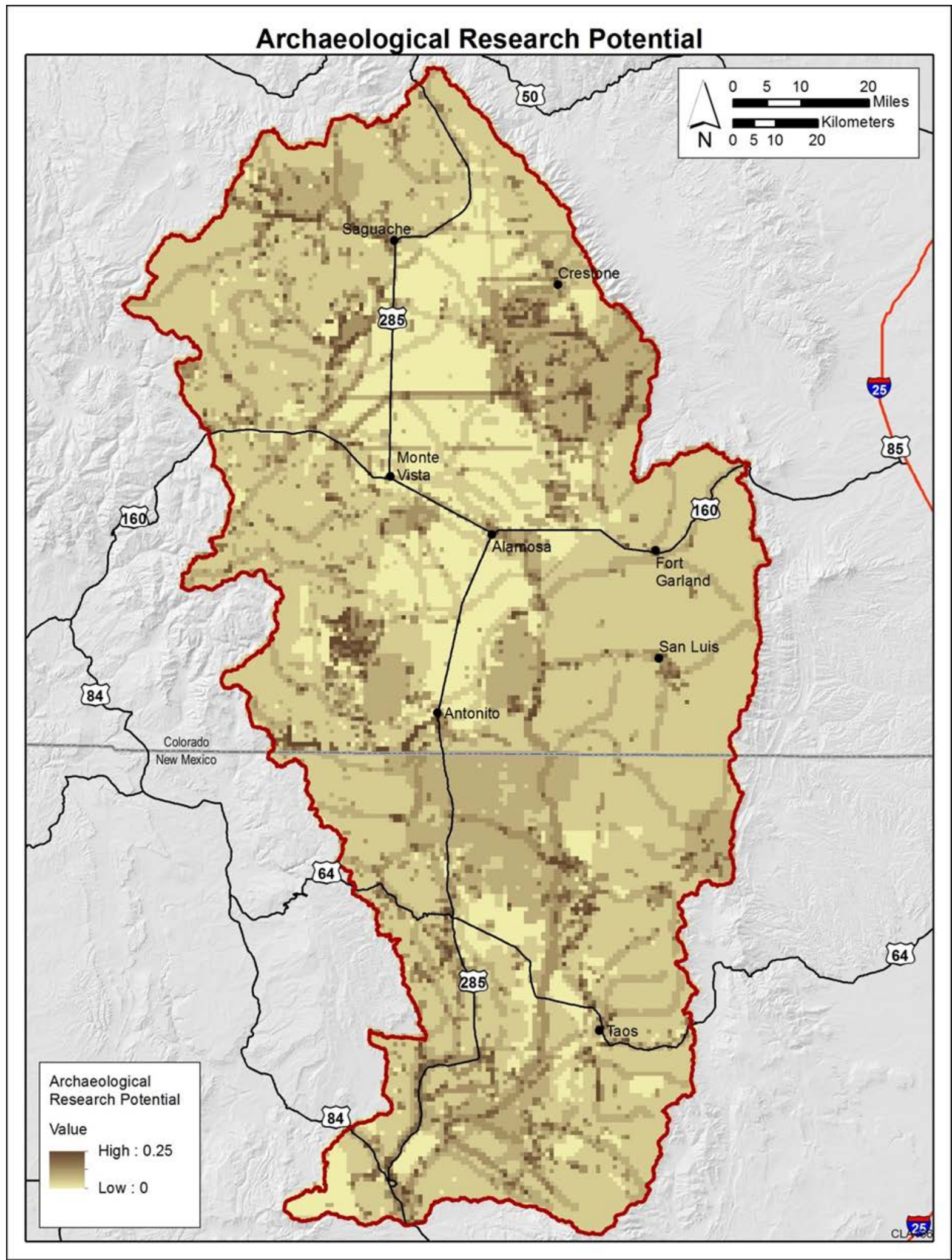

Figure 4-7. Archaeological Research Potential Model 
Table 4-4. Input Layer Scores

\begin{tabular}{|l|l|}
\hline Input Layer/Feature & Score \\
\hline Unsurveyed Areas & 0.2 \\
\hline Unevaluated Sites & 0.2 \\
\hline Historic sites determined not eligible & 0.1 \\
\hline Historic sites determined eligible & 0.2 \\
\hline Federal Land & 0.1 \\
\hline Specially Designated Areas & 0.1 \\
\hline Within 1,500 ft of a water body & 0.1 \\
\hline
\end{tabular}

\subsubsection{Viewshed Value Model}

Impacts on cultural resources are not limited to direct physical impact on a property or site. Other types of impacts like visual intrusions and auditory disturbances can affect one's capacity to use or enjoy a place of cultural importance. This includes, but is certainly not limited to, impacts on a tribal member's ability to perform or participate in a traditional ceremony, a trail enthusiast's ability to hike along a National Historic Trail route and experience the setting of those who traversed the trail during its period of significance, a researcher's ability to search for answers to landscape level questions because the landscape no longer looks the same, and possibly even a Hispano farmer's ability to enjoy the experience of traditional agricultural practices in a traditional setting. For the pilot project, viewsheds were investigated as described below; however, although auditory impacts are mentioned, noise modeling was not investigated further and the mapping of noise model results could be evaluated in future studies.

To address less tangible impacts like visual impacts, a viewshed analysis was conducted to look at a number of key observation points (KOP) within the study area tied to specific cultural resources with a known setting component that is vital to the resource (as examples, Blanca Peak and the Old Spanish National Historic Trail) (Table 4-5; Figure 4-8). A KOP is a point on a travel route, use area, or place of cultural importance where the majority of activity at that point takes place or the view of a management activity would be most revealing. KOPs are typically used as viewpoints for assessing potential visual impacts resulting from proposed projects in the area. In some cases, the elevation around a KOP was analyzed to determine the best location for the viewshed point, if no specific locality was known to be the place that people would go.

The viewsheds are processed with the standard ESRI ArcGIS Viewshed tool accessible via the Spatial Analyst Extension. The fields OFFSETA and RADIUS2 were added to the KOP attribute table to include a target height and maximum distance in the viewshed analysis. The Offset A height (KOP height above ground) was 1.75 meters, the average human height. The extent of the viewshed analysis is 80467.2 meters (50 miles). Ten-meter digital elevation models (DEMs) are used for the analysis, corrections for earth curvature are used, and the refractivity coefficient is kept at the default 0.13 . In several instances, supplementary points for the KOPs were determined using an enhanced KOP methodology. The elevation around the original KOP 


\section{Table 4-5. Key Observation Points}

\begin{tabular}{|r|l|}
\hline \multicolumn{1}{|c|}{ KOPNumber } & \\
\hline 1 & Blanca Peak \\
\hline 2 & Great Sand Dunes \\
\hline 3 & Blanca Wetlands \\
\hline 4 & San Antonio Peak \\
\hline 5 & Ute Mountain \\
\hline 6 & Los Mogotes Peak \\
\hline 7 & Old Spanish Trail 1 \\
\hline 8 & Old Spanish Trail 2 \\
\hline 9 & Old Spanish Trail 3 \\
\hline 10 & Old Spanish Trail 4 \\
\hline 11 & Old Spanish Trail 5 \\
\hline 12 & Old Spanish Trail 5b \\
\hline 13 & Old Spanish Trail 6 \\
\hline 14 & Old Spanish Trail 7 \\
\hline 15 & Chili Line \\
\hline 16 & Cumbres and Toltec Scenic Railroad \\
\hline 17 & Punche Lake \\
\hline 18 & Wismath Craters/Segita Peak \\
\hline 19 & Cerro de la Olla \\
\hline 20 & Cerro Montoso Shrine \\
\hline 21 & Cerro Chiflo and Rio Grande Gorge \\
\hline 22 & Miners Trail Shrine \\
\hline 23 & Taos Pueblo \\
\hline 24 & Pueblo Peak \\
\hline 25 & Fort Garland \\
\hline 26 & Picuris Trail \\
\hline 27 & San Luis Church - Stations of the Cross \\
\hline 28 & Baca Grande Spiritual Center \\
\hline 29 & San Luis Church Peak \\
\hline & \\
\hline & \\
\hline & \\
\hline & \\
\hline &
\end{tabular}

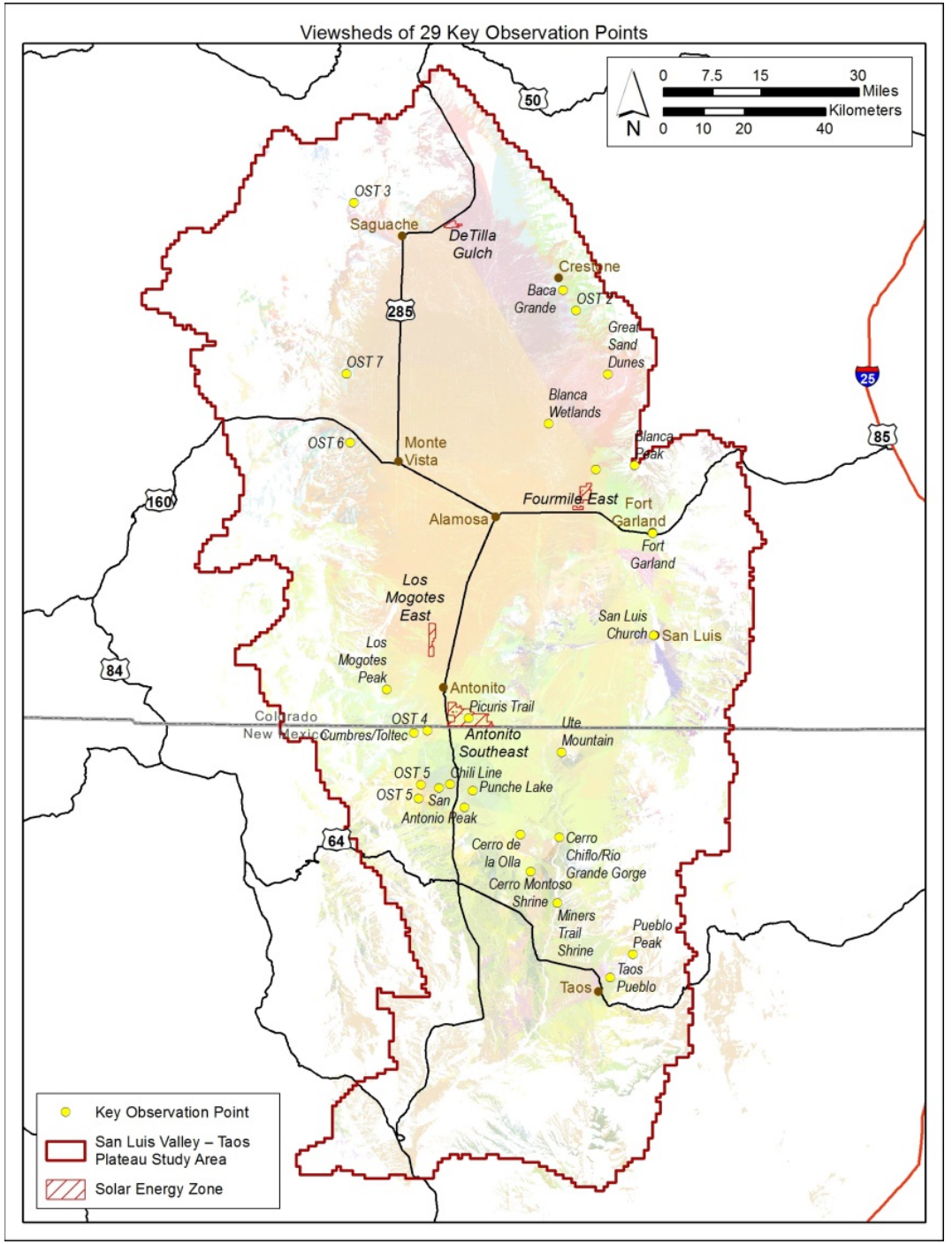

Figure 4-8. Key Observation Points for Cultural Resources with a Significant Visual Setting Component 
is analyzed to determine the best location for the Viewshed point. If there is a better vantage point identified within $500 \mathrm{ft}$ of the original KOP, a supplemental point is added to the analysis. Furthermore, if it is unclear where exactly people would visit, such as at the Great Sand Dunes National Park and Preserve, a grid of points covering the area is used to calculate the viewshed. The viewshed analysis takes into account intervening topography that may preclude a view, but otherwise adds to the cultural value footprint of certain resources. The viewshed analysis also considers distance as a weighting factor, so the derived cultural value of the area declined as the distance from the resource increased. To do this, viewshed rasters are converted to polygons and a score between 0.02 and 1.0 is assigned based on distance from the KOP as shown in Table 4-6 and Figure 4-9. (The darkest red area is closest to the resource, within 1 mile, and represents the zone of highest potential cultural value because of that proximity. Cultural value based on viewshed is assumed to decrease as the distance from the resource increases.)

The results of the intersection of the 29 viewsheds and their weighted scores are shown in Figures 4-10 and 4-11. Figure 4-10 is the composite of all of the scores for all of the viewsheds per $1 \mathrm{~km}$ grid cell as a summed value. The figure shows a continuous gradation from lowest to highest scores. Figure 4-11 shows the same data results of intersecting viewsheds, but, for each $1 \mathrm{~km}$ grid cell, the model generated the max value for each cell by a single viewshed and only that highest value was selected for the final output.

\subsubsection{Cultural Resource Values Model}

The cultural resource values model combines three factors (1) cultural resources of concern (using the coincidence or scoring models), (2) viewshed value, and (3) archaeological research potential, to produce the overall cultural value of a given area. The three components were converted to raster files and normalized so the individual values of each component ranged from zero to one. Composite values for each $1 \mathrm{~km}$ grid cell are calculated using the Raster Calculator to achieve a final score. Inputs are weighted as follows: Cultural resources of concern coincidence (or scoring) model (50\%); viewshed value (25\%); and archaeological research potential (25\%). Viewshed value and archaeological research potential are weighted less because they are derived from smaller subsets of the cultural resources of concern. The results of this model are shown in Figure 4-12 for coincidence and Figure 4-13 for scoring. The darkest areas are the areas of highest cultural value. The results of the scored model do not show as much differentiation in some areas because of the importance of large land areas, like the National Heritage Areas.

\subsubsection{Change Agent Risk Model}

The next step in the assessment determines the trends and determines what may be at future risk based on the trajectories of the change agents. Each of the change agents represents one part of this risk. If it is assumed that all four change agents are equally impacting the cultural landscape, each is weighted 25\%. However, the change agent weighting in the model can be adjusted if it is determined to be likely that certain change agents affect cultural resources more heavily than others. 
Table 4-6. Viewshed Scores by Distance

\begin{tabular}{|l|l|}
\hline Distance & Score \\
\hline $30+$ miles & 0.02 \\
\hline $20-30$ miles & 0.1 \\
\hline $10-20$ miles & 0.2 \\
\hline $5-10$ miles & 0.6 \\
\hline $1-5$ miles & 0.8 \\
\hline Within 1 mile & 1.0 \\
\hline
\end{tabular}

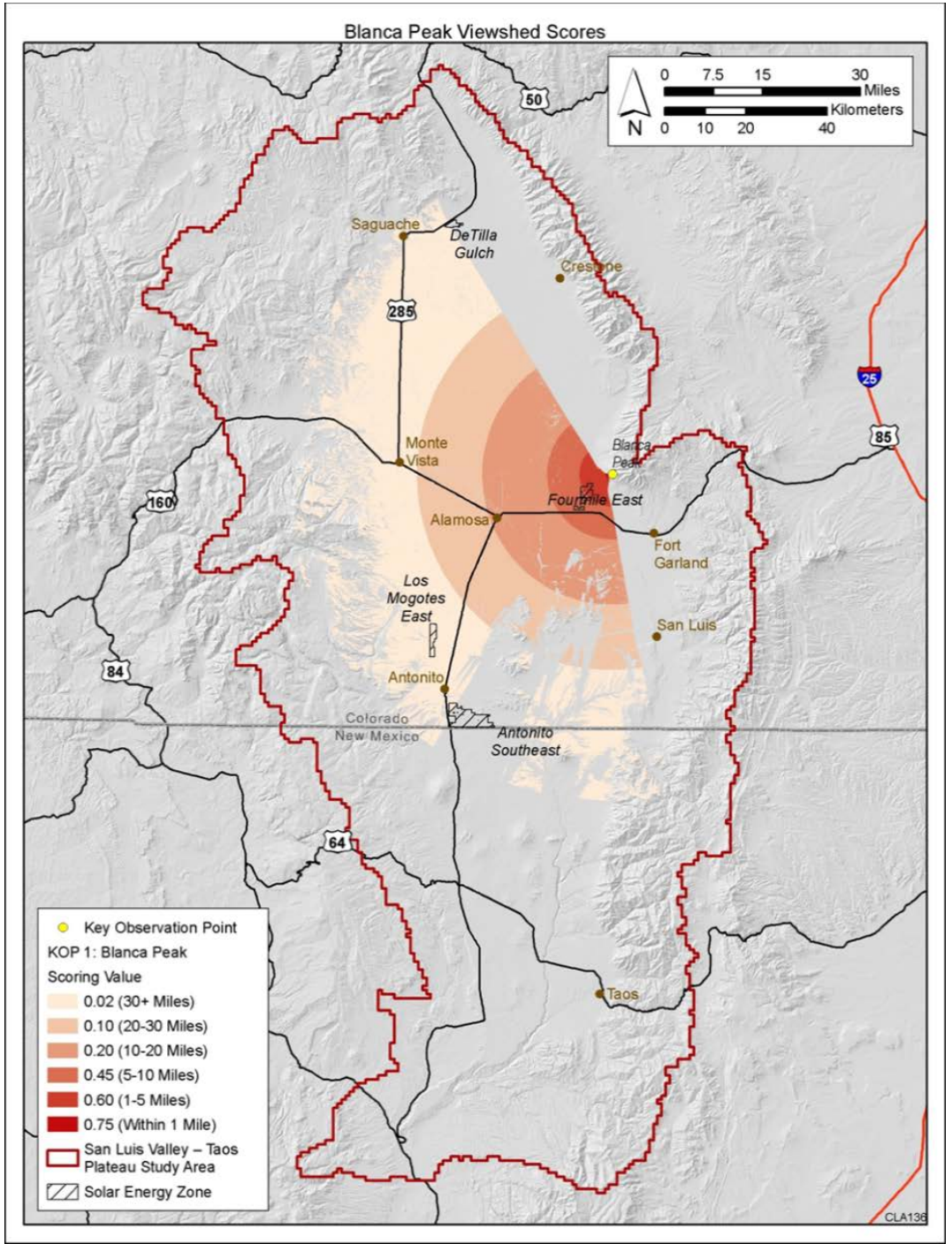

Figure 4-9. Viewshed Scoring Method 


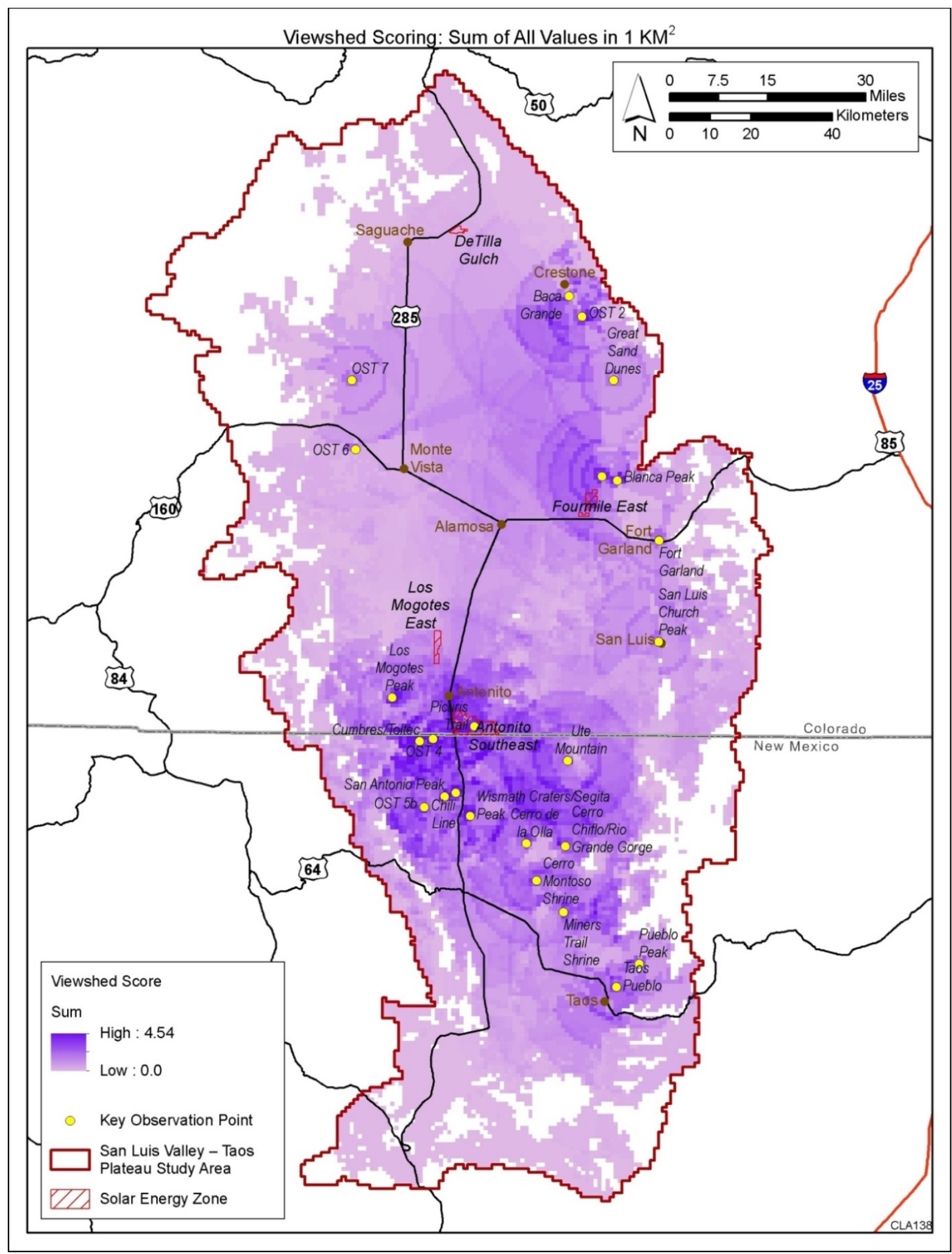

Figure 4-10. Viewshed Analysis of Cultural Resources within San Luis Valley - Taos Plateau Study Area (Sum) 


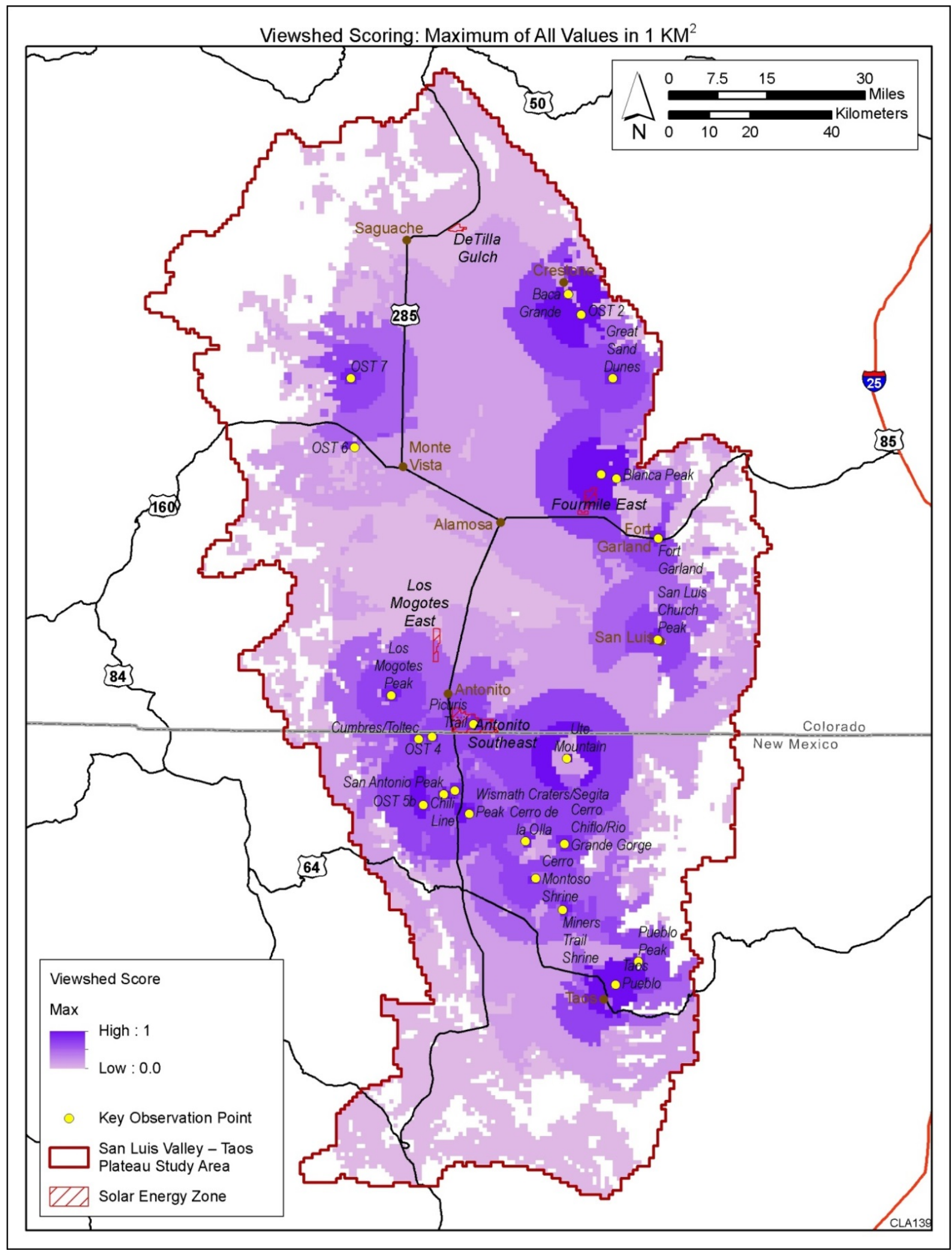

Figure 4-11. Viewshed Analysis of Cultural Resources within San Luis Valley - Taos Plateau Study Area (Max) 


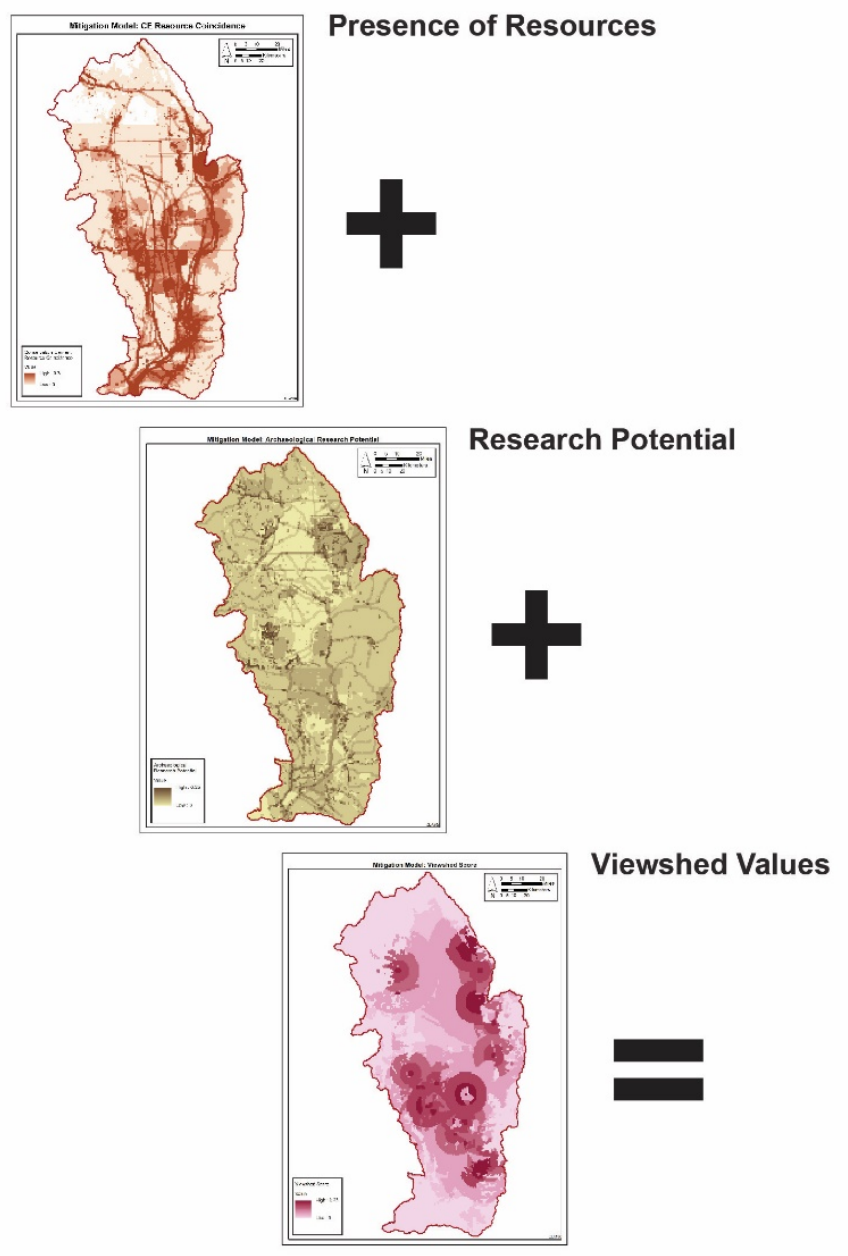

\section{Cultural Resource Value (Coincidence)}

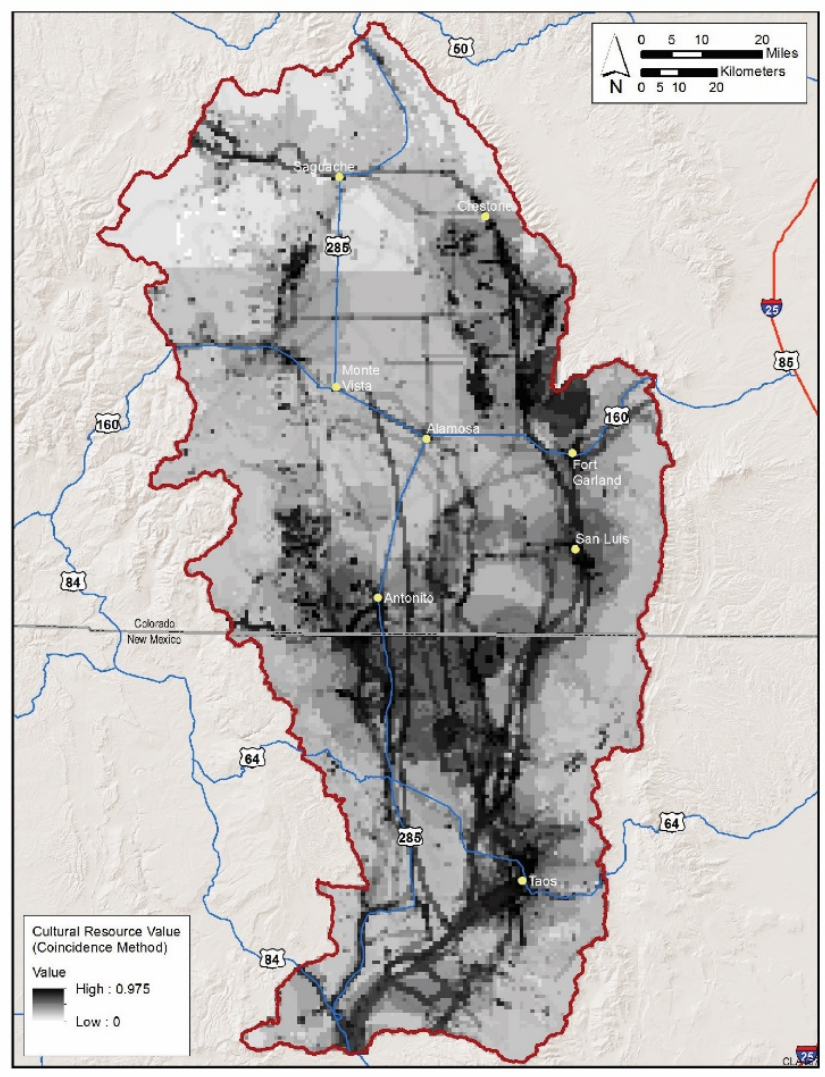

D

Figure 4-12. Calculation of Cultural Resource Values (Coincidence) 


\section{Cultural Resource Value (Scored)}
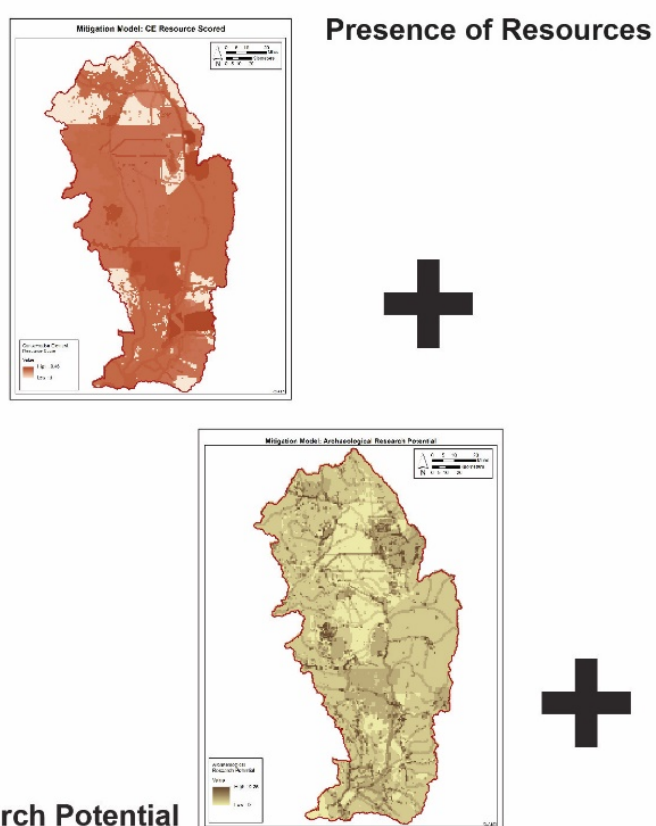

Research Potentia
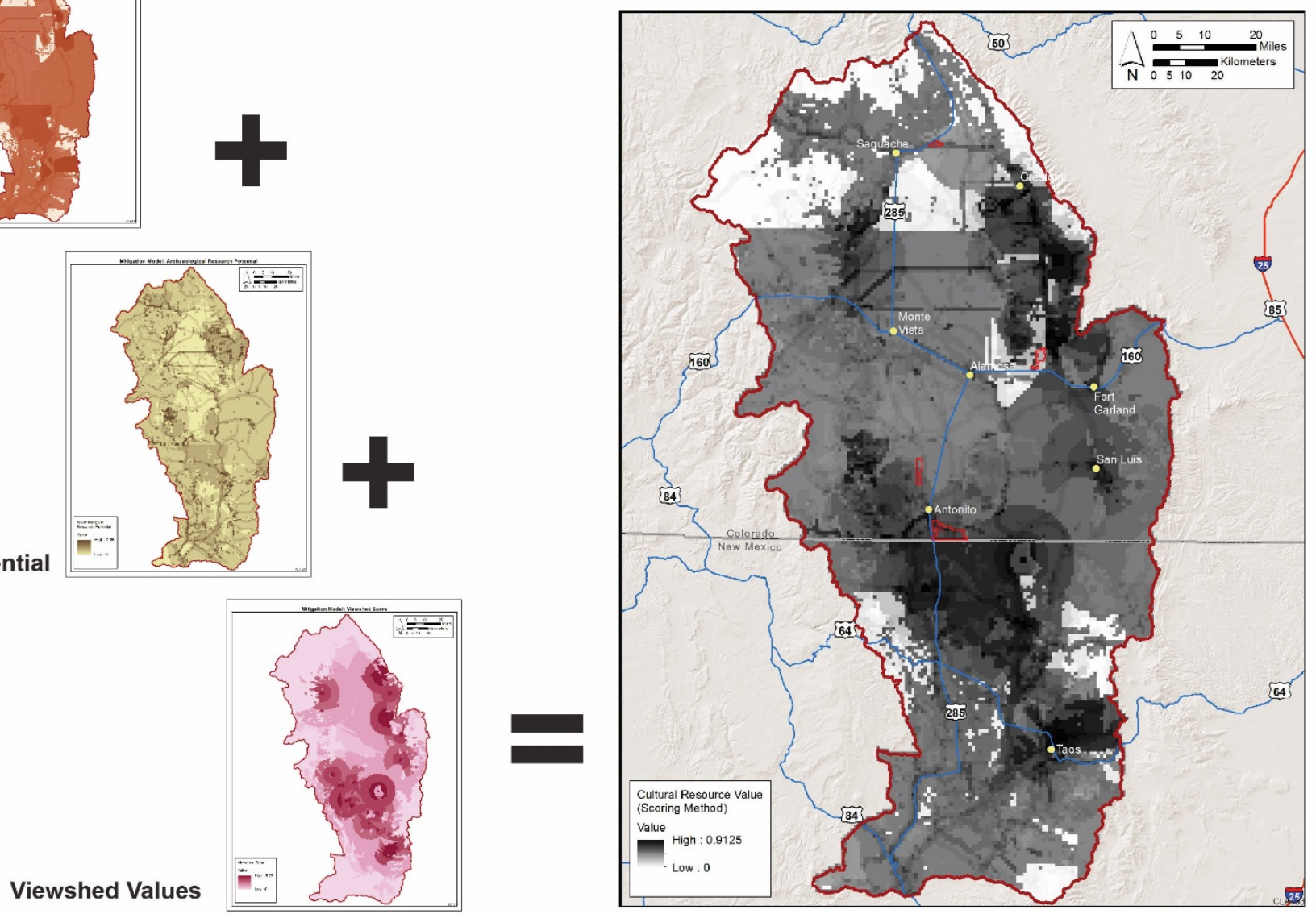

Figure 4-13. Calculation of Cultural Resource Values (Scored) 
The model is run with the future case for climate change, wildfire, and invasive species, insects, and disease. For the human development case the model is run looking at the change detection between the current and future human development cases (Figure 4-14). The four change agents are converted to raster files and values are calculated using the Raster Calculator in the Spatial Analyst Extension to achieve a final score per $1 \mathrm{~km}$ unit cell. Inputs from each change agent model are weighted at $25 \%$ each (i.e., value x 0.25 ) so the composite score of all four change agents would not exceed a value of 1 . The results of this model are shown in Figure 4-15; the darkest orange colors are areas of highest risk from the combination of the change agents. Appendix B provides the breakdown of each conservation element by each change agent to get at more specific contributions of each change agent on ach conservation element.

\subsubsection{Mitigation Potential Model}

The mitigation potential model was developed in the pilot to see how assessment of the cultural conditions and trends might be able to support the solar regional mitigation strategy. This model combines the results of the cultural resource value and change agent risk models. In order to get a useful and interpretable result, the first run of this model looked at high risk and high value resources with the objective that this would show the areas of greatest importance (i.e., not looking at individual cultural conservation elements) and where these resources would experience the most risk from all of the change agents. Using Jenk's Natural Breaks in ArcGIS, each raster output was classified into six categories. The two categories with the highest values were used to represent high risk or high resource value. The output rasters were reclassified via the Reclassify Tool in the Spatial Analyst Extension to isolate the high areas. The mitigation potential results are shown in Figure 4-16; areas shown in red are areas where near-term action to protect the cultural values of that area is recommended.

The model was run a second time to look at low risk and high value resources. The same method was used to identify low risk areas, with the two categories with the lowest values isolated via the Reclassify Tool. The mitigation potential results are shown in Figure 4-17. Green areas are areas with high cultural value that are considered stable (i.e., at low risk of change over time) and where conservation actions are recommended to continue protecting those areas into the future.

To take a conservative approach and capture as much of the study area with cultural values as possible, this process was applied to the conservation element scoring method output and the conservation element coincidence method output. The two high cultural resource value rasters were added together via Raster Calculator, and then reclassified to create a binary (0 or 1$)$ high cultural value raster. To calculate overlap, the binary high risk raster was added to the binary high cultural value raster via Raster Calculator. Those cells with a value of "2" are the areas of high risk/high cultural value overlap. The same method was applied to the low risk/high resource overlap (with low risk being classified as the 1 value instead of high risk). 


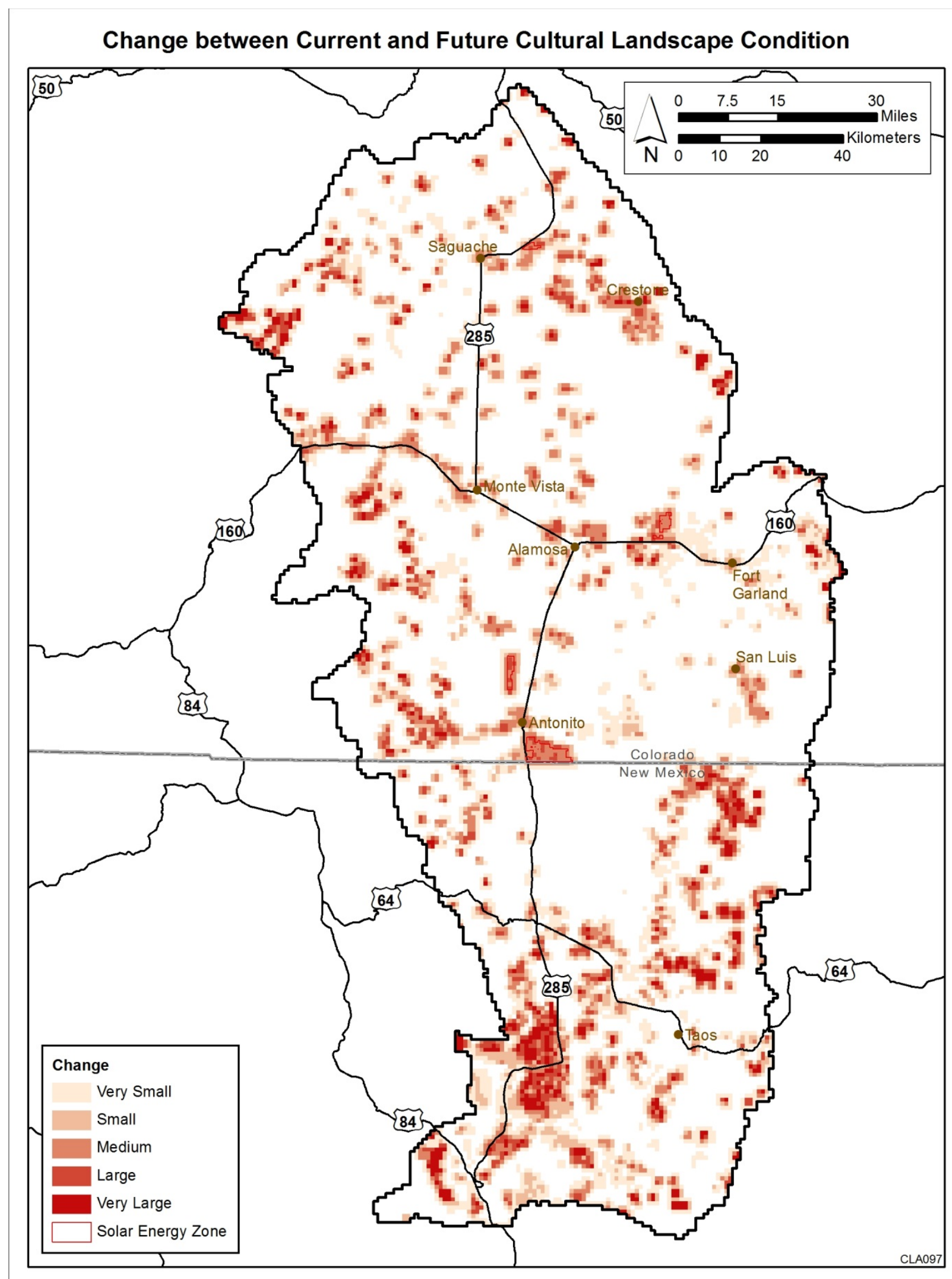

Figure 4-14. Areas of Greatest Human Development Change in the Future 


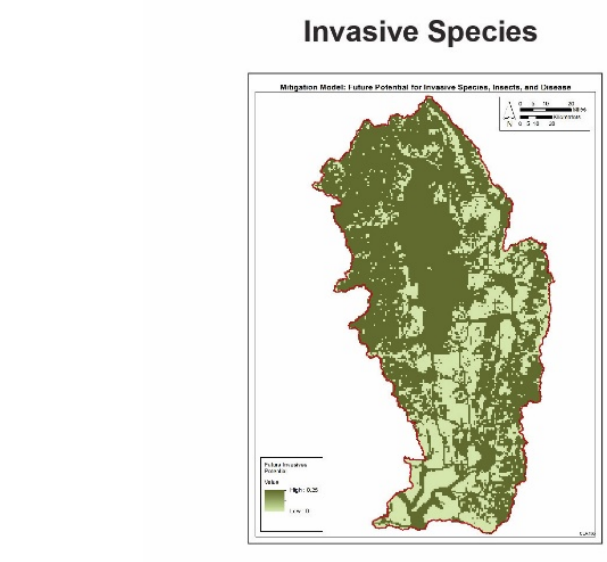

$\stackrel{\infty}{\bigcup}$

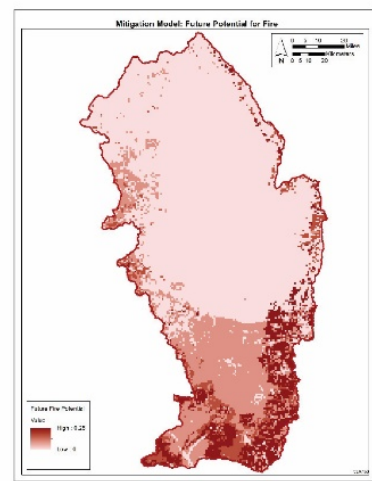

Wildfire
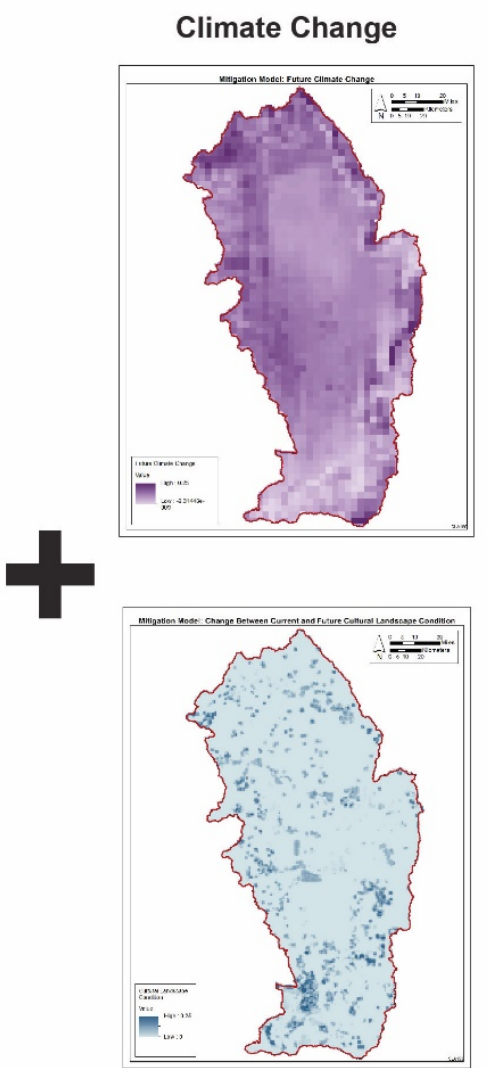

Human Development

\section{Change Agent Risk}
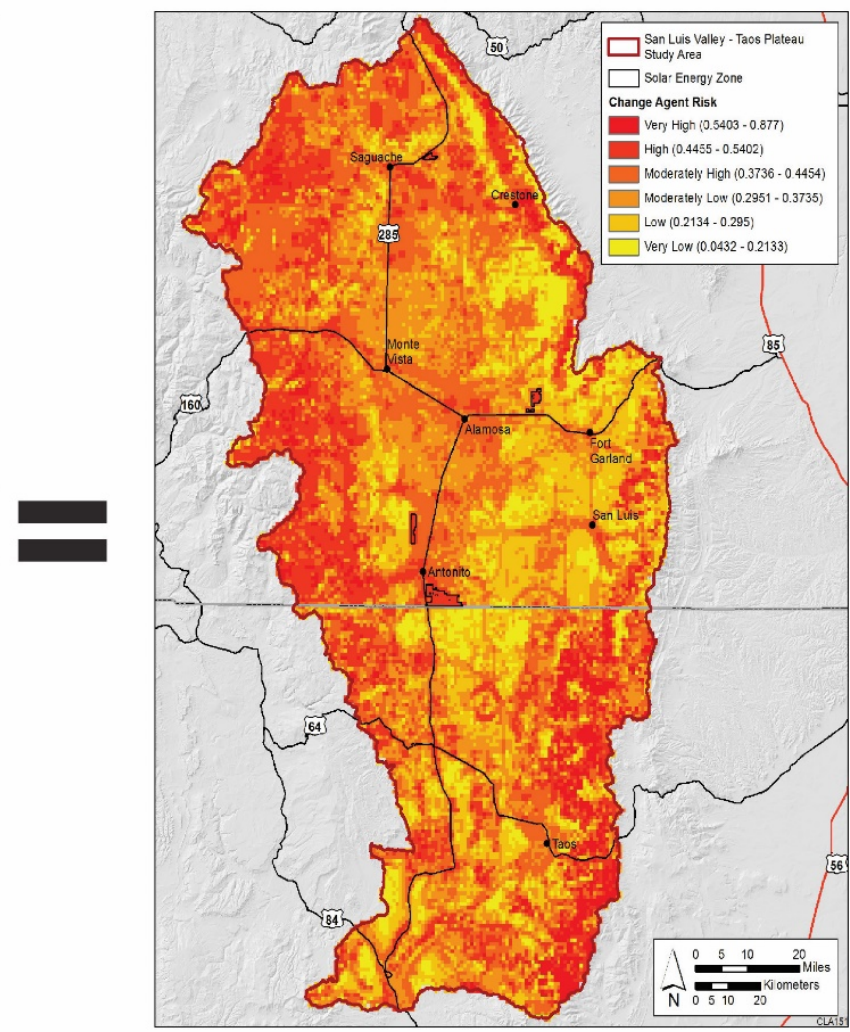

Total Risk

Figure 4-15. Calculation of Areas of Greatest Change Agent Risk Resulting from Projected Future Conditions 


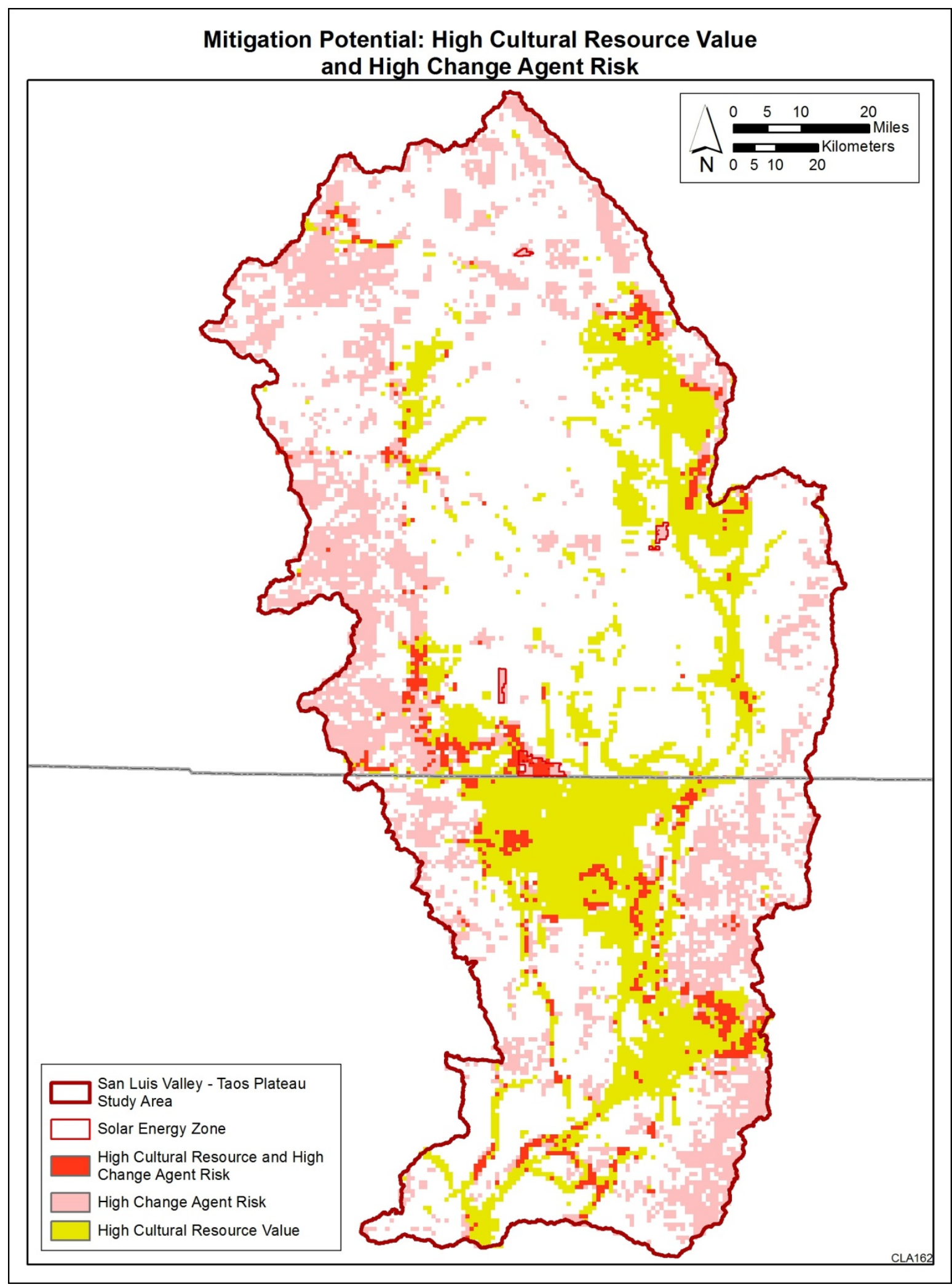

Figure 4-16. Intersection of High Cultural Value and High Change Agent Risk Models 


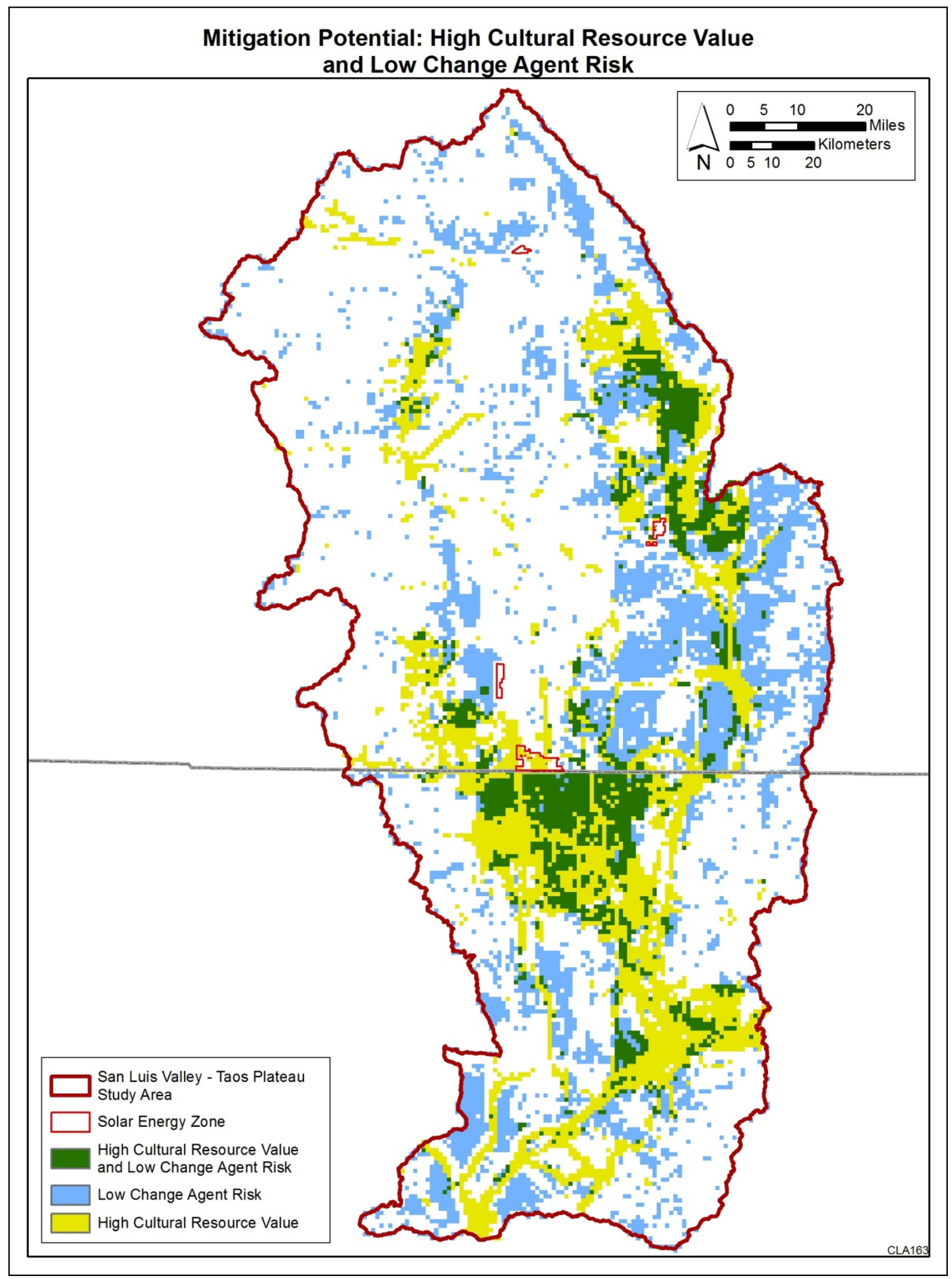

Figure 4-17. Intersection of High Cultural Value and Low Change Agent Risk Models 
Final SLV-TP Landscape-Level

October 2016

Cultural Heritage Values and Risk Assessment

Page Intentionally Left Blank 


\section{EVALUATION OF CURRENT AND FUTURE CONDITIONS}

The assessment of current and future conditions of the San Luis Valley - Taos Plateau relies heavily on current and future cultural landscape condition model described in Section 4.2.2 of this document and the change agent models described in Section 3.2 of the Landscape Assessment (Walston et al. 2016). Because the assessments to evaluate condition and trends result in large amounts of data, this section only looks at the roll-up of all of the cultural conservation elements; Appendix B includes evaluation of condition and trends for each of the individual cultural conservation elements. It is anticipated that future users of the data and models presented here will have specific geographic areas and site types in mind for analysis and will want to analyze the data directly for the change agents affecting their area of interest. Examples of trends are described in this section and in Appendix B, but because there are so many possible outcomes the descriptions only scratch the surface.

The methodology for assessing future conditions and trends follows closely to what is presented in the Landscape Assessment. The future case is 15 years from now (2030) for the change agents of human development, invasive species, and wildfire. For climate change the future horizon is 45 years, or 2060. Condition is evaluated on the basis of cultural conservation element distribution relative to the current change agent model outputs, while trends are based on results from future change agent model outputs. Intersections of those change agent-conservation element distributions are created to determine where the conservation elements might be most affected by the change agents throughout the study area. Bar graphs are produced to show which proportion of the conservation element distributions may experience change agents differently and provide a mechanism for evaluating condition and trend by comparing current and future conditions.

Figure 5-1 shows the spatial distribution of all of the cultural conservation elements, and Figure 5-2 illustrates current and future cultural landscape condition for all of the cultural conservation elements based on the modeling described in Section 4.2.2. Figures 5-3 and 5-4 provide the full distribution of cultural conservation elements intersected with each of the change agents separately at current and future conditions, respectively. The change agent models are identical to those used for the Landscape Assessment and details on their derivations are described in full in that document (Walston et al. 2016). The bar graphs in Figure 5-5 are intended to show the trends from current condition to future condition based on percentage of area affected. For example, areas of very high density of invasive species, insects, and disease within the distribution of all cultural conservation elements are expected to increase by nearly $10 \%$ in the near-term future (i.e., by 2030). Interestingly, climate change shows no net increase or decrease for very high potential. However, by looking at the changes in distribution of climate change from the current and future models, it becomes clear that although the amount of acreage categorized as very high potential for climate changeis essentially the same, the areas experiencing change in temperature and precipitation now are not the same areas expected to be experiencing change in the future. Results may be quite different when looking at a specific element, like traditional collection areas. 


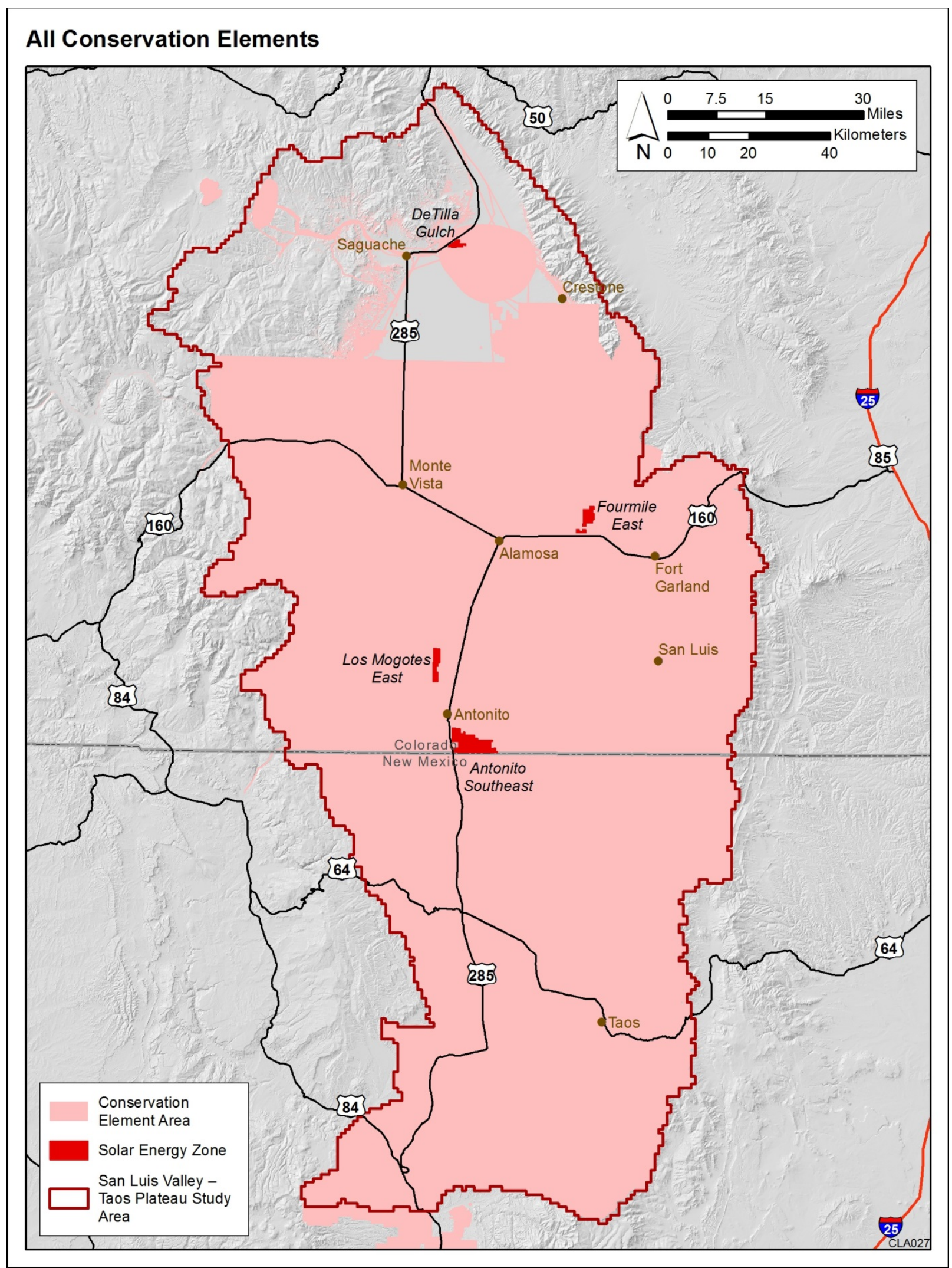

Figure 5-1. Current Distribution of All Cultural Conservation Elements 

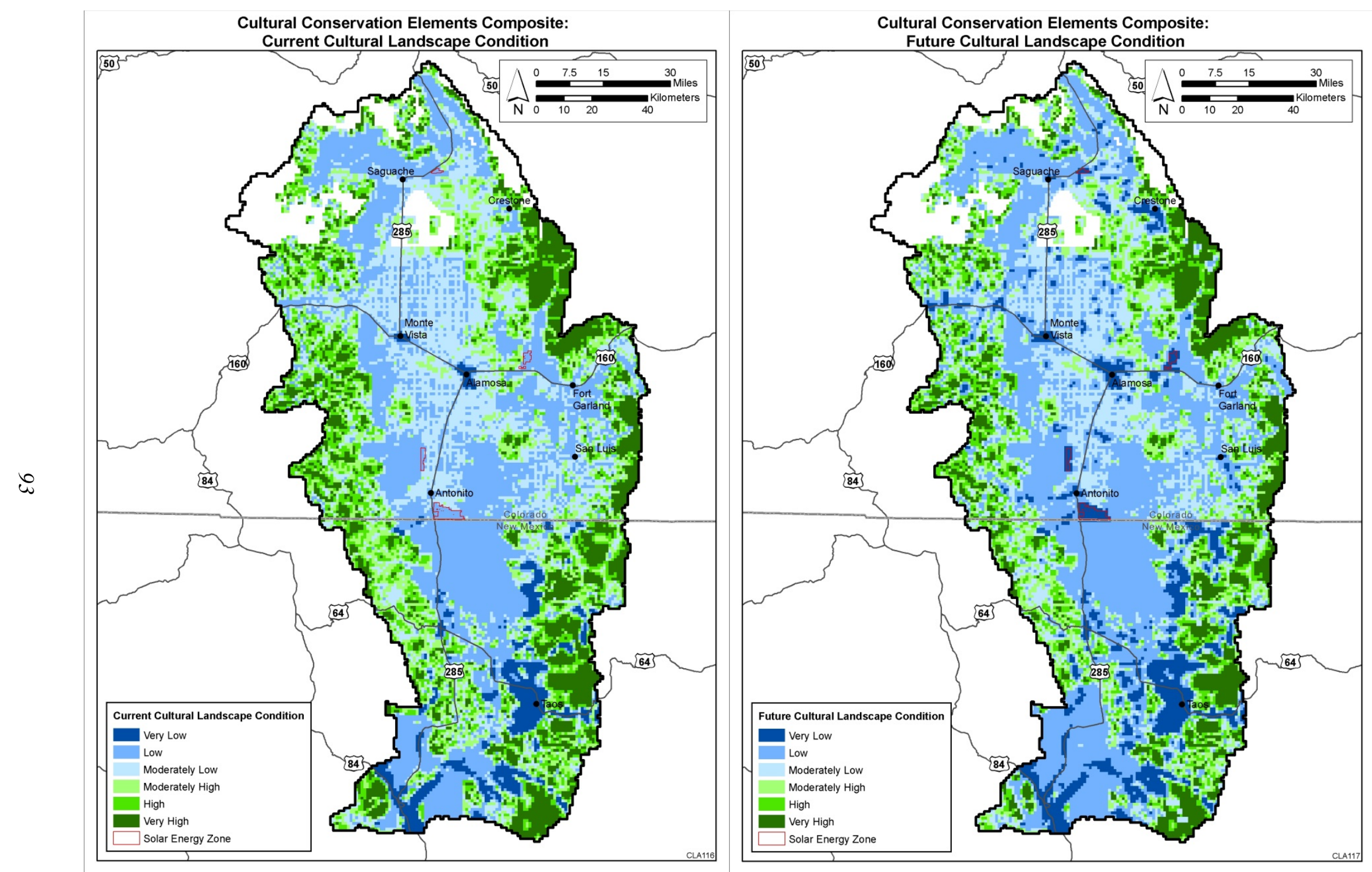

Figure 5-2. Current and Future Cultural Landscape Condition of All Cultural Conservation Elements 

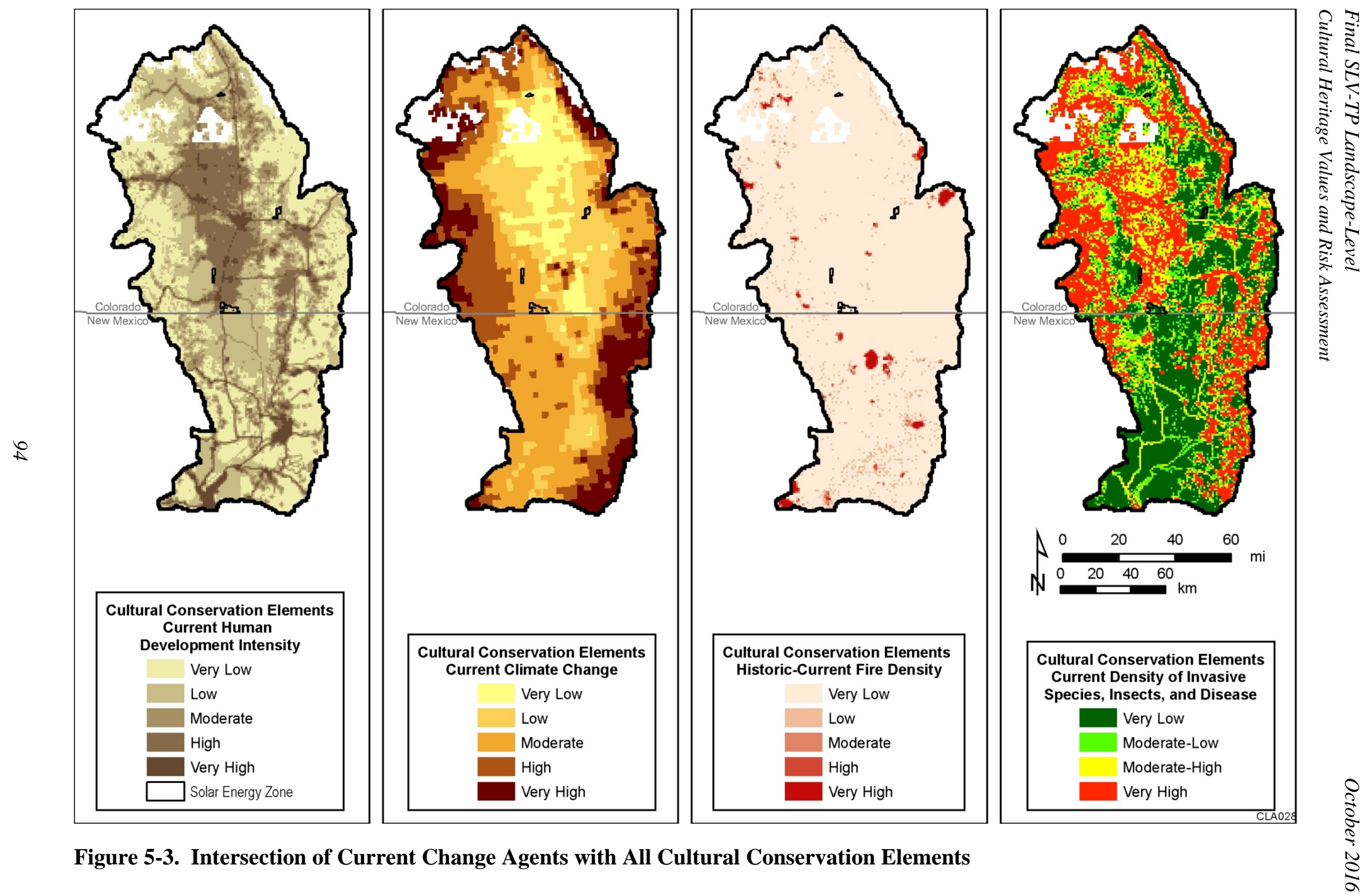

Figure 5-3. Intersection of Current Change Agents with All Cultural Conservation Elements 

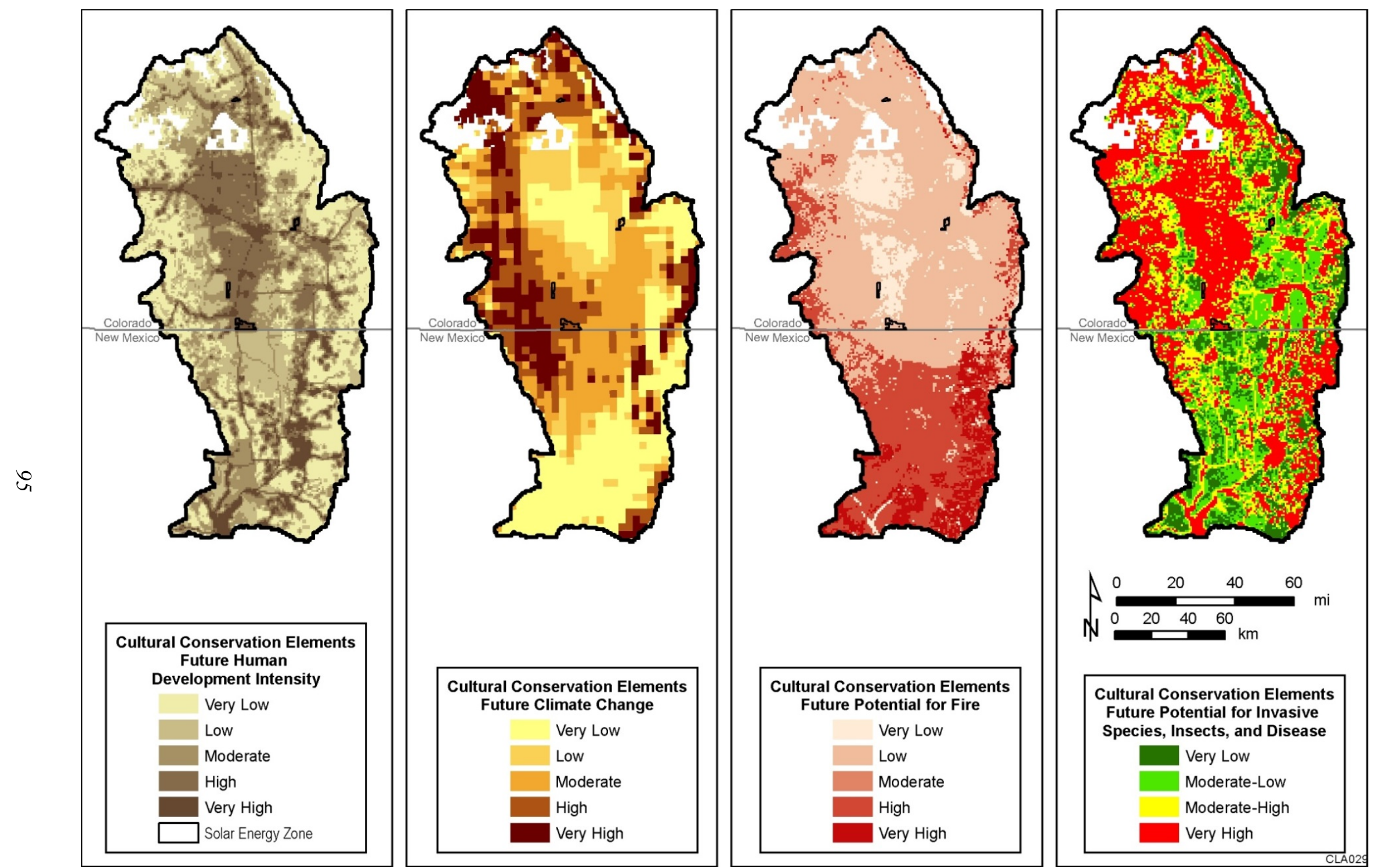

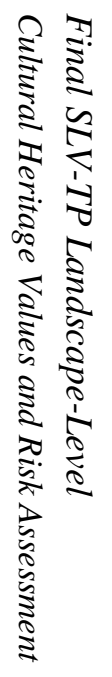

Figure 5-4. Intersection of Future Change Agents with All Cultural Conservation Elements 


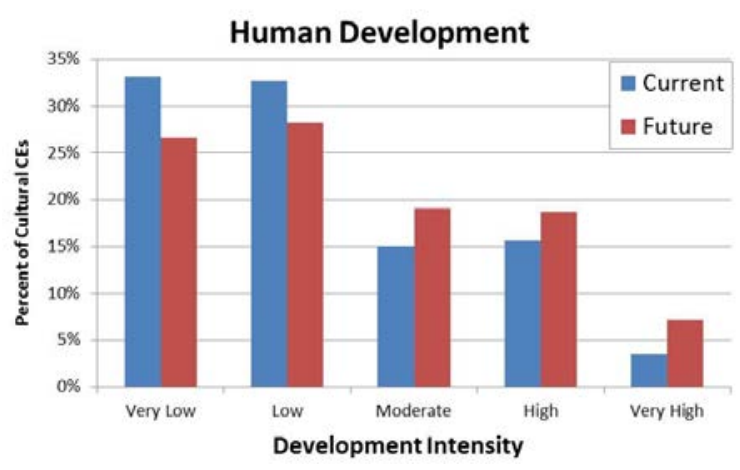

Wildfire

\%

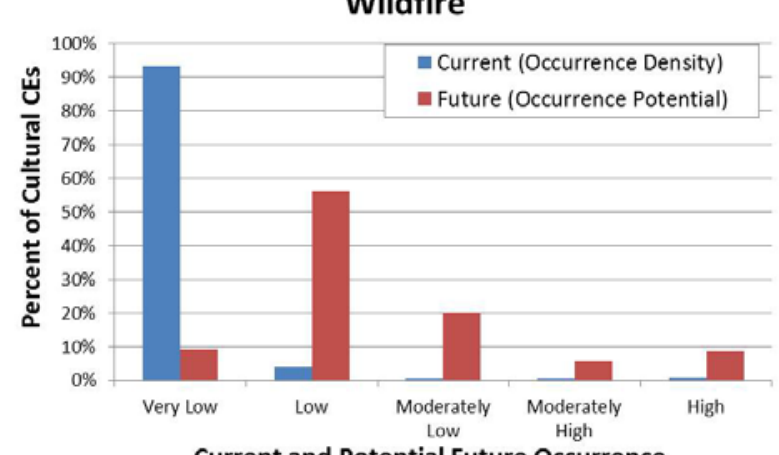

Current and Potential Future Occurrence

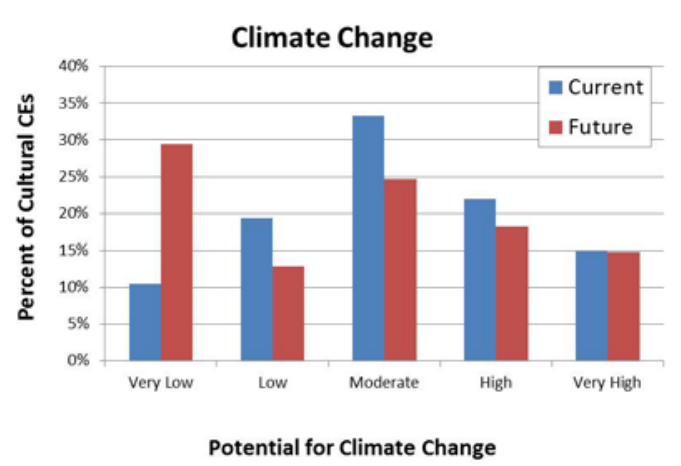

Invasive Species, Insects, and Disease

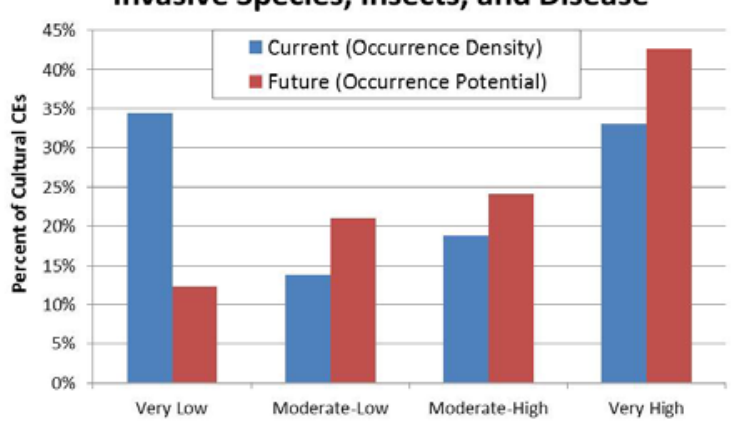

Current and Potential Future Occurrence

Cultural Landscape Condition

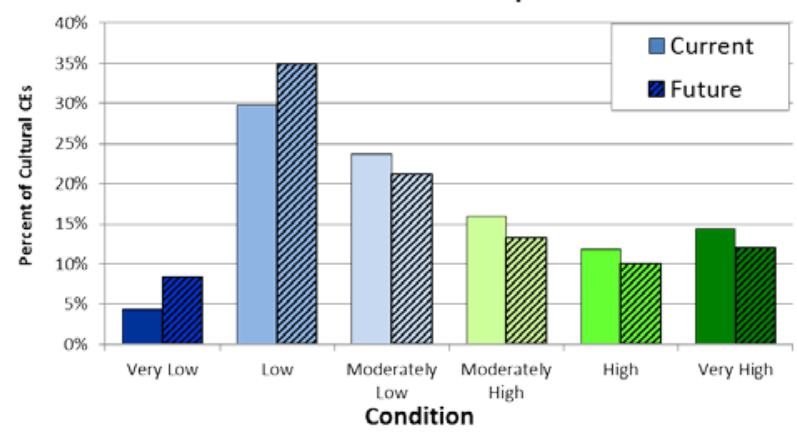

Figure 5-5. Predicted Trends in All Cultural Conservation Elements within the Study Area 
Because these figures represent all of the cultural conservation elements, these data can be used to assess where these elements collectively are at risk from an individual change agent. Appendix B, alternatively, illustrates where each individual conservation element is at risk from individual change agents. Ultimately, as described in Sections 4.2.6 and 4.2.7 the change agents can also be combined to get a composite of change agent risk that can be intersected with the areas of highest cultural value. The resulting trends evaluation shows certain areas in the ecoregion that have both high cultural value and high levels of risk of change from one or more of the change agents (areas shown in red in Figure 4-15). These areas are potentially at greatest risk for possible loss or degradation and may require near term actions, such as: fencing, data recovery, erosion control, administrative protections, law enforcement, etc. The recommended actions and time frames would be dependent on resource-specific factors, setting, and the parameters in the model that indicate the source of highest risk. Similarly, for certain areas in the ecoregion the evaluation indicated high cultural value paired with low levels of risk from the change agents (areas shown in green in Figure 4-16). These areas are potentially very stable locations that may make excellent research areas, conservation areas, or preserves depending on the resources present and their integrity. 
Final SLV-TP Landscape-Level

October2016

Cultural Heritage Values and Risk Assessment

Page Intentionally Left Blank 


\section{LESSONS LEARNED AND FUTURE CONSIDERATIONS}

Overall the pilot landscape-level cultural heritage values and risk assessment successfully demonstrates that the REA approach can work for the cultural environment. The concepts behind the change agents as drivers of a shifting landscape apply sufficiently well because cultural use of the land is highly correlated with ecological function. People depend on the wildlife, the flora, the water, and the entire ecosystem balance for survival. Historical use of the landscape capitalizes on the exploitation of natural resources, and many areas have great depth of use over time because of the resources present that meet basic human needs (for example, presence of fresh water). The correlation of ecological function with cultural resource values was an underlying assumption when this pilot was proposed, so it was thought that the relationship between people and the natural environment make the REA a potentially reasonable approach for evaluating the cultural landscape. The other appealing characteristics about the REA approach were that it was being rapidly deployed throughout the west and was establishing a nomenclature that was becoming familiar to many land managers and resource specialists. By maintaining consistency in approach and vocabulary with the ecological assessments, the cultural assessments may be able to gain some momentum for landscape-scale analyses and get incorporated into day-to-day planning activities more readily.

As a pilot project, there was a great deal of uncertainty regarding which REA methods would work for the cultural environment and which ones might not. There were also factors that arose during the cultural assessment that were not evaluated in the REAs, but seemed important to consider, such as addressing the importance of the visual setting for some resources and considering vast areas not systematically surveyed for archaeological sites as having research value. This section describes some of the lessons learned during the course of the cultural assessment and opportunities for further refinement of what is presented in this document. Also, because this assessment was conducted in support of the Solar Regional Mitigation Strategy for three solar energy zones in Colorado, two extra steps were considered in this document, beyond what is typically presented in the REAs: 1 ) a regional research design to identify relevant research questions and 2) a value-risk analysis to reach an understanding of how the compiled information can be used for determining possible regional mitigation locations. It is recommended that additional work be completed to prioritize the research questions identified in Section 3.0 (Cultural Conservation Elements Regional Research Design) to further identify the highest priority research goals for the region and use those priorities for developing a more robust scoring model.

One of the first dilemmas in the assessment was a matter of scale. The Colorado Plateau Level III ecoregion did not cover the San Luis Valley where the solar energy zones were located. A Level IV ecoregion was proposed as an ecoregion sufficiently large enough to encompass the solar energy zones, but not so large as to require a time commitment for producing the Landscape Assessment beyond that of the time needed to produce a regional mitigation strategy for solar development. Fortunately, the Level IV ecoregion also seemed particularly well-suited for a pilot cultural assessment, as the area is bounded naturally by the Sangre de Cristo and San Juan Mountains with discrete points of entry and egress helping to delineate human land use patterns across the landscape. Of the several REAs completed to date at the size of a Level III ecoregion, most data are summarized at a $1 \mathrm{~km}^{2}$ and $4 \mathrm{~km}^{2}$ grid cell size. For the slightly smaller 
Level IV ecoregion, the Landscape Assessment and the cultural assessment typically rolled up the data into $1 \mathrm{~km}^{2}$ square units. In a cultural resource management framework the tendency is to focus on cultural resources site by site and project by project, neither of which is typically at this large scale. However, from a predictive model or site density perspective, the larger scale is appropriate, and fits the objectives of recent BLM/DOI policy to apply landscape scale approaches to land use management planning decisions. Section 106 requirements of the National Historic Preservation Act of 1966, as amended ${ }^{3}$, remain applicable and there is no question that site-specific analyses for compliance purposes will continue at the smaller site or project scale. However, the intent of this assessment is to streamline that initial process of land use planning and management to make smarter, faster, and more environmentally (and culturally) friendly decisions when it comes to individual projects in the future. In the end, for this solar-energy development driven assessment, the chosen scale of the analysis proved suitable. The scale, however, can and should vary depending on the questions being asked and the management decisions expected to be made.

Availability of indicators and generation of conceptual models for the cultural assessment was another challenge. Another common relationship between ecological resources and cultural resources is the process by which resources are identified, i.e., through survey. As with cultural surveys, ecological surveys are not typically conducted until a project is proposed. For the REAs, broad-scale information about habitat and other environmental conditions associated with a particular species or group of co-existent species is used as an indicator for potential species presence without conducting actual field surveys. For this cultural assessment, those broad-scale indicators are not sufficiently developed and not rapidly attainable for the wide range of activities and varying patterns associated with human culture and development. In the absence of those indicators, the cultural assessment follows more closely to a straight conservation element analysis, evaluating each cultural conservation element according to current condition (or status) and trend for each change agent. At this time, conceptual models have not been generated for the analysis because of the wide range of topics and processes that could fall under each conservation element (e.g., eligible prehistoric properties cover many different types of sites dating to over a 10,000-year period). It is possible that those conceptual models can be developed in the future, but it was not possible during the time frame of this pilot.

Other than some sensitive species locations, like raptor nests, most of the ecological data are publicly available. The REA approach, named for its "rapid" assessment of best available data, is readily conducive to sharing data and building upon existing data as additional survey or research is conducted. The cultural assessment also will benefit over time from new surveys and research projects being added to the models, but it differs from the ecological assessment in two ways. First, much of the data used in this assessment are not publicly available and cannot be publicly available in order to protect sensitive archaeological sites, traditional use areas, and other confidential locations. Nonetheless, the non-sensitive datasets should continue to be shared

3 The National Historic Preservation Act of 1966 became Public Law 89-665 and was codified in Title 16 of the United States Code (U.S.C.). It was amended on numerous occasions, and in December of 2014, Public Law 13-287 moved the Act's provisions from Title 16 to Title 54. What was formerly referenced as Section 106 (16 U.S.C. 470f) was moved to 54 U.S.C. 306108; however the terminology of Section 106 continues to be used. Implementing regulations are still found at 36 Code of Federal Regulations, Part 800. 
as they can offer much to the future development of heritage tourism, educational materials, and research proposals and grants, to name a few possible contributions. It was suggested in the November 2015 peer-review workshop that consideration should be given to the hierarchical release of information. That type of structure seems plausible, but further consideration is needed to develop that release structure. For the time being, the distribution of GIS data associated with this assessment will be limited to the agency archaeologists and GIS specialists who assist with land use planning decisions and cultural (heritage) resource management.

The second difference from the ecological assessment, as described earlier under data collection and data management in Section 4.1, is that best available data for the cultural assessment were not always readily available as digital spatial data. The conversion of narrative data about numerous locations (e.g., from historic contexts, oral histories, and ethnographies) to spatial data is time consuming and speculative regarding the "boundaries" of these areas. Ways to address fuzzy boundaries are needed. Currently, many locations are identified in the GIS as "points" or "lines," for example for communities and trails, respectively, but they are buffered, typically by one-quarter to one-half miles to provide an area of analysis at the regional scale. A scientific basis or method for establishing those areas should be developed in the future for ensuring consistency among assessments.

In working in the human dimension, an area with many cultural constructs that shape one's beliefs, care should be taken not to try to display some cultural concepts, emotions, beliefs, contexts, etc., through spatial means. Some things are better captured through oral history or written narrative. This assessment tried to limit the analysis to resources known to be present at specific locations or in larger areas. The viewshed analysis may be one modeling exercise that needs some further thought, as the intent of the analysis is to spatially capture a sense of being part of the traditional or historic landscape, assuming that what one can see encapsulates that notion from a particular known location (i.e., from a ceremonial place or along a national historic trail). Again trying to capture that sense from a spatial perspective without truly comprehending how others might "view" the landscape, might not accurately reflect the culturally sensitive areas. The same would hold true for any auditory analysis that might be completed in the future.

From a data and modeling perspective a few modifications to the assessment are recommended, many of these suggestions were identified during the peer-review workshop:

- Water should be added to the list of change agents. This was recommended on several occasions because of the significant role that water plays in the ecoregion in terms of availability, quality, and use. It is envisioned that water would be a secondary change agent, not that different from invasive species, insects, and disease and wildfire, which both seem to be influenced by human development and climate change. Precipitation directly influences water availability and human development often influences water quality and uses, as well as availability. Changes in water use in a land use planning scenario can have an ecosystem function impact that would also be important for the REAs to consider.

- Climate change models need to be more robust. Current climate change models are only indicating where change might occur in levels of precipitation or temperature, but the 
outputs are absolute values, so the predicted direction of change (hotter or colder, wetter or drier) for a given location is unknown. Obtaining more precise estimates of climate change impacts could be a crucial element for both the REAs and the cultural assessments because it could strongly affect agency management decisions.

- Additional investigation is needed for developing the change agent weights for the risk model, based on the relative extent each change agent affects cultural resources. In the pilot assessment, the change agents were weighted equally. Similarly, additional investigation is needed to determine the most appropriate parameter values for the cultural landscape condition model, particularly regarding the values of distance of influence and site impact score. Adjustments to the ecological assessment landscape condition model were made based on professional judgment in the absence of documented studies. Differentiation among agricultural methods is also needed.

- A data standard should be implemented to normalize the varying data sets that are integrated in the assessment and provide a common nomenclature and organizational structure for maintaining the assessment's utility in the future, especially as data are updated and models need to be rerun.

- For the cultural assessments, paleoenvironmental data should be included as part of the environmental baseline, where they are available, and could be used to inform the archaeological research potential model.

- Traditional sheepherding practices are not currently included in any of the conservation elements and should be included in the future. Research questions on this topic were included with research questions for the historic eligible properties cultural conservation element in Section 3.7.2.

- Stakeholder scoring should be implemented to assist the agencies in developing the scoring model of cultural resources of concern. Clear metrics and criteria to be followed in order to implement this would need to be developed. It was obvious during the pilot that priority scoring was fraught with potential pitfalls, especially with a limited number of participants. Although the coincidence model was favored in this particular assessment as "making more sense," it was stated in the peer-review workshop that participants saw value in the scoring method, and, if more rigorously applied with a greater number of participants (in particular non-agency participants), the model could yield informative results. Also, as stated earlier in this section, prioritizing research questions would make scoring of cultural resource value a little easier and more robust, since the ability to answer the highest priority research goals is suggested as one of the scoring criteria.

Lastly, it was suggested that the cultural assessments should receive additional review external to the agencies, including more robust coordination with tribes and other non-agency stakeholders. It is highly recommended that more coordination and outreach be conducted for future assessments, now that the pilot has demonstrated this approach is tenable. This is recommended in connection with the potential hierarchical release of data as discussed earlier in this section, so that confidential information/data are protected. 


\section{CONCLUSION}

As indicated previously in Section 6, the landscape-level cultural heritage values and risk assessment successfully demonstrates that the REA approach can be applied to the cultural environment. The pilot project achieved its threefold purpose to: (1) document the current status of the most important and at-risk cultural resources that have shaped the collective history and cultural heritage of the San Luis Valley - Taos Plateau; (2) evaluate the trends and vulnerability of these resources to change agents over time (human development, climate change, wildfire, and invasive species); and (3) help focus regional compensatory mitigation efforts on the most important and at-risk cultural resources in the region. The results of the cultural heritage values and risk assessment can further support regional compensatory mitigation evaluations, through identifying the cultural value and risk level from change agents of potential mitigation actions and locations. The Solar Regional Mitigation Strategy for the Colorado SEZs is using this approach to evaluate candidate mitigation sites and actions. Particularly valuable could be the identification of locations with both high ecological value (as identified in the Landscape Assessment) and high cultural value (as identified in this report), where compensatory mitigation could have additive benefits.

In addition to assisting the solar regional mitigation strategy, this landscape-level study can support additional uses across the various agencies that manage lands within the San Luis Valley - Taos Plateau ecoregion. This assessment supports a baseline of information and data that are crucial for developing future planning documents within agencies, but also can be used to assist in aligning planning efforts among the agencies and foster future collaborations. In addition to supporting analysis of locations for compensatory mitigation actions, the information herein can support identification of conservation areas unrelated to mitigation projects. Sharing information on research needs and data gaps, as well as conditions and trends of known resources, can help spur additional research in the region. Local universities, National Heritage Areas, and various other research organizations can use the information and model results in this assessment to design and implement future research projects, promote heritage tourism, and provide ideas for grant applications, to name a few possibilities.

An example of how the cultural heritage values and risk assessment has already assisted agency planning efforts is BLM's consideration to no longer promote Fourmile East SEZ for future solar development. The results of the cultural assessment reinforce that the areas in and around the Fourmile East SEZ have a high cultural value. This information, which includes available ethnographic information (Higgins et al. 2013), as well as additional ecological and visual results from the Landscape Assessment and the Visual Resource Analysis for Solar Energy Zones in the San Luis Valley (Walston et al. 2016 and Sullivan et al. 2016, respectively), support BLM's rationale to not include the Fourmile East SEZ in the current solar regional mitigation planning effort for the CO SEZs. Additional actions are underway by the BLM to formally remove Fourmile East from consideration for solar energy development.

The cultural environment is very dynamic, and this assessment represents a snapshot in time, based on best available information. The GIS data can be updated regularly to include new and improved information, so that the models can be rerun or new cultural conservation elements added. The change agent models themselves are also likely to change over time, especially as the 
future scenario for three of the four change agents is based on a 15-year time span. It is recommended that the assessment be evaluated continuously for applicability and appropriateness. The full assessment can be rerun when it is determined significant new information might alter results. This may be every 5 to 10 years, or less, depending on the rate of growth or change or research that is occurring in the region, and also on availability of funding. The scale of the assessment should also be kept in mind as the data are considered for future projects and planning.

It is hoped, based on the results of this pilot project, that additional information will continue to be collected and synthesized across the West, to build on the flexibility and varying scales of analysis that a landscape approach can provide to land managing agencies, the research community as a whole, and the stakeholders whose lives are delicately intertwined with the cultural heritage of these lands. 


\section{REFERENCES}

Anderson, Duane, 1999. All That Glitters: The Emergence of Native American Micaceous Art Pottery in Northern New Mexico. Published by the School of American Research Press, Sante Fe, New Mexico.

Baker, S.G., et al., 2007, "Protohistoric and Historic Native Americans,” pp. 29-87 in M.C. Church et al, Colorado History: A Context for Historical Archaeology, Colorado Council of Professional Archaeologists, Denver.

Blake, Robert Bruce, 2010. ESPEJO, ANTONIO DE, in Handbook of Texas Online. Published by the Texas State Historical Association. Available at: http://www.tshaonline.org/handbook/online/articles/fes03. Accessed September 09, 2015.

BLM (Bureau of Land Management), 1998. Handbook 8270 Paleontological Resource Management. United States Department of Interior, Bureau of Land Management. August.

BLM, 2004. Handbook 8100 The Foundations for Managing Cultural Resources (Revised). United States Department of Interior, Bureau of Land Management. December.

BLM, 2012. Informational Bulletin (IB) 2012-58, The Bureau of Land Management's Landscape Approach for Managing the Public Lands. Available at:

http://www.blm.gov/wo/st/en/info/regulations/Instruction_Memos_and_Bulletins/national_infor mation/2012/IB_2012-058.html. Accessed September 9, 2015.

BLM, 2014a. Solar Regional Mitigation Strategy for the Dry Lake Solar Energy Zone. Tech Note 444. Bureau of Land Management, Southern Nevada District Office, Las Vegas, NV. Electronic Document available at: http://www.blm.gov/style/medialib/blm/wo/blm_library/ tech_notes.Par.29872.File.dat/TN_444.pdf. Accessed September 10, 2015.

BLM, 2014b. Rio Grande del Norte National Monument Fact Sheet. Available at: http://www.blm.gov/nm/st/en/prog/blm_special_areas/national_monuments/rio_grande_del_nort e.html/. Accessed April 27, 2015.

BLM, 2016a. Rapid Ecoregioanl Assessments. Available at: http://www.blm.gov/wo/st/en/prog/ more/Landscape_Approach/reas.html. Accessed March 15, 2016.

BLM, 2016b, Regional Mitigation Strategy for the Dry Lake Valley North Solar Energy Zone, Final Report, Report for the U.S. Department of the Interior, Bureau of Land Management, Washington, D.C., July. Available at :http://www.blm.gov/nv/st/en/fo/ ely_field_office/blm_programs/energy/dry_lake_valley_north/project_documents.html.

BLM, 2016c, Regional Mitigation Strategy for the Arizona Solar Energy Zones, Final Report, Report for the U.S. Department of the Interior, Bureau of Land Management, Arizona State Office. Available at http://www.blm.gov/az/st/en/prog/energy/solar/arizona_regional_ mitigation.htm. 
BLM, 2016d. Draft Solar Regional Mitigation Strategy for the Colorado Solar Energy Zones. Available at: http://www.blm.gov/co/st/en/fo/slvfo/solar/solar_regional_mitigation.html.

BLM and DOE (BLM and U.S. Department of Energy), 2010. Draft Programmatic Environmental Impact Statement for Solar Energy Development in Six Southwestern States, DES 10-59, DOE/EIS-0403, Dec.

BLM and DOE, 2012, Final Programmatic Environmental Impact Statement (PEIS) for Solar Energy Development in Six Southwestern States. FES 12-24, DOE/EIS-0403. U.S. Department of the Interior, Bureau of Land Management and U.S. Department of Energy.

Brown, G.M. (editor), 1991. Archaeological Data Recovery at San Juan Coal Company's La Plata Mine, San Juan County, New Mexico, Technical Report no. 355. Mariah Associates, Inc., Albuquerque, New Mexico.

Brown, M.T., and B. Vivas. 2005. "Landscape development intensity index,” Environmental Monitoring and Assessment 101:289-309.

Brugge, D.M., 1983. "Navajo Prehistory and History to 1850," in Handbook of North American Indians, Volume 10, pp. 489-501. William C. Sturtevant (editor). Smithsonian Institution, Washington, D.C.

Buchanan, Robert H., 1971. “The San Luis Valley-A Land of Paradox,” in San Luis Basin (Colorado), James, H.L. [ed], New Mexico Geological Society $22^{\text {nd }}$ Annual Fall Field Conference Guidebook.

Bureau of Reclamation, 1995. Operation of Glen Canyon Dam: Colorado River Storage Project, Arizona, Final Environmental Impact Statement. U.S. Department of the Interior, Bureau of Reclamation, Salt lake City, Utah, March. Available at: http://www.usbr.gov/uc/library/envdocs/eis/gc/gcdOpsFEIS.html. Accessed February 19, 2015.

Button, V.T., 1980, Archaeological Investigations in the Closed Basin of Colorado's San Luis Valley, Report No: WP-SLV-CRI-001. Prepared for the U.S. Department of the Interior, Water and Power Resources Service, Southwest Regional Office, Amarillo, Texas, March.

Callaway, D., et al., 1986. “Ute,” pp. 336-367 in Handbook of North American Indians, Vol. 11, Great Basin, W. D’Azevedo (editor), Smithsonian Institution, Washington, D.C.

Cappa, James, and Chester Wallace, 2007. Geology and Mineral Resources of Saguache County, Colorado. Colorado Geological Survey, Department of Natural Resources, Denver Colorado.

Carter, C.J., and S.F. Mehls, 1984. Colorado Southern Frontier Historic Context. Colorado Historical Society, Denver. 
Chapman, S.S., Griffith, G.E., Omernik, J.M., Price, A.B., Freeouf, J., and Schrupp, D.L., 2006. Ecoregions of Colorado (color poster with map, descriptive text, summary tables, and photographs): Reston, Virginia. U.S. Geological Survey (map scale 1:1,200,000).

Center for Land Grant Studies, 2005. "Land Grant Database Project.” Available at: http://www.southwestbooks.org/grantsaj.htm. Accessed September 9, 2015.

Church, M., S.G. Baker, B.J. Clark, R.F. Carrillo, J.C. Horn, C.D. Spath, D.R. Guilfoyle, and E.S. Cassells, 2007. Colorado History: A Context for Historical Archaeology. Colorado Council of Professional Archaeologists, Denver.

Colorado Climatic Data Center, 2014. "Period of Record Monthly Climate Summary for Alamosa, Co.” Available at: http://www.wrcc.dri.edu/cgi-bin/cliMAIN.pl?coalam. Accessed September 9, 2015.

Colorado Division of Reclamation Mining \& Safety, 2014. Mining Data Reports. Database accessible at: http://mining.state.co.us/Reports/MiningData/Pages/SearchbyCounty.aspx. Accessed on September 9, 2015.

Colorado Parks and Wildlife, n.d. "Learn About Wildlife.” Available at: http://cpw.state.co.us/learn/Pages/default.aspx/. Accessed December 18, 2014.

Colorado Supreme Court, 2002. Lobato v. Taylor, 71 P.3d 938, 956.

Colorado Tourism Office, 2015. Colorado Scenic Byway: Los Caminos Antiguos and Great Sand Dunes National Park. Available at: http://www.colorado.com/articles/colorado-scenicbyway-los-caminos-antiguos-great-sand-dunes-national-park. Accessed November 10, 2015.

Comer, P.J., and J. Hak, 2012. "Landscape Condition in the Conterminous United States, Spatial Model Summary,” NatureServe, Boulder, CO. Available at:

http://s3.amazonaws.com/AppGeo/WestGovChat/Downloads/Natureserve\%20Landscape\%20Co ndition\%20LCv4_WGA.pdf. Accessed October 18, 2016.

Comer, P., P. Crist, M. Reid, J. Hak, H. Hamilton, D. Braun, G. Kittel, I. Varley, B. Unnasch, S. Auer, M. Creutzburg, D. Theobald, and L. Kutner. 2013. Mojave Basin and Range Rapid Ecoregional Assessment Report. Prepared for the U.S. Department of the Interior, Bureau of Land Management, June.

C\&TSRR (Cumbres and Toltec Scenic Railroad), 2012. Press Release: Interior Secretary Ken Salazar Designates the Cumbres \& Toltec Scenic Railroad a National Historic Landmark. Available at: http://cumbrestoltec.com/2012/11/05/ctsrr-designated-a-national-historiclandmark/. Accessed September 9, 2015.

C\&TSRR, 2015. “Cumbres and Toltec Scenic Railroad History.” Available at: http://cumbrestoltec.com/history/. Accessed September 9, 2015. 
Dyer, H.C., 2009. Paleontological Ground Truthing Survey in the Rio Grande National Forest, Colorado, Rio Grande National Forest, Monte Vista, Colo., Sept. 15.

Earthship Biotecture, 2015. Available at: http://earthship.com/design-principles. Accessed September 15, 2015.

Eiselt, B. Sunday, and Richard I. Ford, 2007. "Sangre de Cristo Micaceous Clays: Geochemical Indices for Source and Raw Material Distribution, Past and Present.” Kiva Vol. 73, No. 2, The Rio Arriba (Winter, 2007), pp. 219-238.

Enchanted Circle, 2015. “Enchanted Circle of Northern New Mexico.” Available at: http://www.enchantedcircle.org/index.php. Accessed September 9, 2015.

EPA (Environmental Protection Agency), 2015. "Final National Priorities List.” Available at: http://www.epa.gov/superfund/sites/query/queryhtm/nplfin.htm\#CO. Accessed September 15, 2015.

Fink, Robert, 1970. National Register of Historic Places Nomination Form-Fort Garland.

GAO (Government Accounting Office), 2001. Treaty of Guadalupe Hidalgo, Definition and List of Community Land Grants in New Mexico. United States General Accounting Office, Report to Congressional Requesters. September.

Golten, Ryan, 2005. "Lobato v. Taylor: How the Villages of the Rio Culebra, the Colorado Supreme Court, and the Restatement of Servitudes Bailed Out the Treaty of Guadalupe Hildago.” Natural Resources Journal 45:457-494. Spring.

Guthrie, M.R., P. Gadd, R. Johnson, and J.J. Lischka, 1984. Colorado Mountains Prehistoric Context. Colorado Historical Society, Denver.

Higgins, H.C., E. Perez, B. Cribbin, E. Degutis, A. Krall, and A. Minjares, Jr., 2013. Cultural Continuity: An Ethnographic Study Related to Potential Solar Energy Development in the San Luis Valley, Colorado. Prepared for the Bureau of Land Management. September.

LCASB (Los Caminos Antiguos Scenic Byway), 1999. Los Caminos Antiguos Scenic and Historic Byway Partnership Plan. December.

Lennon, Jane, and Steve Mathews, 1996. Cultural Landscape Management: Guidelines for identifying, assessing and managing cultural landscapes in the Australian Alps National Park. Cultural Heritage Working Group Australian Alps Liaison Committee. Jane Lennon and Associates. March.

Lindsey, K.D., 1983. Paleontological Inventory and Assessment of the San Luis Resource Area. Prepared by Denver Museum of Natural History for U.S. Bureau of Land Management, Canon City District, Colo., Dec. 31. 
Lowers, Mary, 2014. “Gold Fever in the San Luis Valley.” The Crestone Eagle. July 28. Available at: http://www.crestoneeagle.com/gold-fever-in-the-san-luis-valley/. Accessed April 27, 2015.

Martorano, M., T. Hoefer, M. Jodry, V. Spero, and M. Taylor, 1999. Colorado Prehistory: A Context for the Rio Grande Basin. Colorado Council of Professional Archaeologists, Golden, Colorado.

Mendinghall, Joseph Scott, 1978. National Register of Historic Places Nomination Form-Pike's Stockade.

Mondragon-Valdez, Maria, 2000. The Culebra River Villages of Costilla County Colorado, Multiple Property Submission. June.

Murphy, Lawrence R., 1973. Arizona and the West (15:1). Excerpt on SMU in Taos's website. Available at: http://www.smu.edu/Taos/FortBurgwin. Accessed September 9, 2015.

New Mexico Acequia Association, 2010. Map of Regional Acequia Associations. New Mexico Acequia Association, Santa Fe, New Mexico.

New Mexico Department of Game and Fish, n.d. Biota Information System of New Mexico. Available at: http://www.bison-m.org/speciesreports.aspx. Accessed December 18, 2014.

NPS (National Park Service), 2001. National Historic Trail Feasibility Study and Environmental Assessment Old Spanish Trail. July. Available at:

http://parkplanning.nps.gov/document.cfm?parkID=454\&projectID=12591\&documentID=38207 Accessed September 9, 2015.

NPS, 2012. “Extended Solar PEIS Visual Impact Analysis from Key Observation Points along the El Camino Real de Tierra Adentro National Historic Memorandum,” June 22.

NPS and BLM (Bureau of Land Management), 2004. El Camino Real Tierra Adentro National Historic Trail. Comprehensive Management Plan/Final Environmental Impact Statement. Long Distance Trails Group, Santa Fe NPS and New Mexico State Office, BLM. Available at: http://www.nps.gov/elca/parkmgmt/comprehensive-management-plan.htm. Accessed April 2, 2014.

NRGNHA (Northern Rio Grande National Heritage Area), 2013. The Northern Rio Grande National Heritage Area Management Plan. May. Available at: http://riograndenha.org/What_We_Do/Management_Plan/index.html. Accessed September 9, 2015.

Old Spanish Trail Recognition Act of 2002. Senate Report 107-203.

Opler, M.E., 1936. “A Summary of Jicarilla Apache Culture,” American Anthropologist 25 38(2):202-223. 
Orient Land Trust, 2015. Orient Mine. Available at: http://www.olt.org/mine. Accessed September 9, 2015.

Rael y Ortega, Tessie and Judy Cuddihy, 2003. Excerpt from Another Time in This Place: Historia, Cultura y Vida en Questa. Web Document. Accessed January 13, 2015. Available at: http://dev.newmexicohistory.org/filedetails.php?fileID=21982.

RCC (Rio Culebra Cooperative), 2015. Rio Culebra Cooperative Website URL: http://www.rioculebra.com/index.html. Accessed September 9, 2015.

Rodriguez, Sylvia, 2007. Acequia: Water-sharing, Sanctity, And Place. School for Advanced Research Press. Santa Fe, New Mexico.

San Luis Valley Museum Association, 2014. “Fort Garland Museum.” Available at: http://www.museumtrail.org/fortgarlandmuseum.asp. Accessed September 9, 2015.

Sauguache County, 2015. "Bonanza: A History of Mining.” Available at: http://www.saguache.org/towns/bonanza/. Accessed September 9, 2015.

Sayles, Stephen, and Jerry Williams, No Date. Land Grants.

SdCNHA (Sangre de Cristo National Heritage Area), 2013. Sangre de Christo National Heritage Association Management Plan. February. Available at: http://sdcnha.org/js/management-plansdcnha.html. Accessed September 9, 2015.

Simmons, Virginia, 1999. The San Luis Valley: Land of the Six-Armed Cross. University Press of Colorado, Niwot, Colorado.

Simmons, V.M., 2000. The Ute Indians of Utah, Colorado, and New Mexico. University of Colorado Press, Boulder, Colo.

Smallidge, S.T., B.C. Thompson, W.R. Gould, L.E. Kantar, U.A. Rosauer, R.A. Deitner, 2003. Demographics, temporal and spatial dynamics, and resource conflict evaluation of elk wintering near San Antonio Mountain in north central New Mexico. Final Report, Federal Aid Project W136-R, New Mexico Department of Game and Fish, Santa Fe, New Mexico, USA.

SMU (Southern Methodist University) in Taos, 2014. SMU-IN-TAOS, Fort Burgwin. Website URL: http://www.smu.edu/Taos/About. Accessed September 9, 2015.

Spero, Vince, 2007. Distribution and Sources of Lithic Material in the Rio Grande Basin. On file at the San Luis Valley Public Lands Center, Monte Vista.

Spero, V., and T. Hoefer III, 1999. “Chapter 4: History of Archaeological Investigations.” In Martorano et al., Colorado Prehistory: A Context for the Rio Grande Basin, Colorado Council of Professional Archaeologists, Golden, Colorado. 
Stoffle, R. W., R. Toupal, J. Medwied-Savage, S. O’Meara, K. Van Vlack, H. Dobyns, H. Fauland, D. Dukes, D. Borysewicz, and J. Madrill, 2008. Ethnohistoric and Ethnographic Assessment of Contemporary Communities along the Old Spanish Trail. Prepared for the National Park Service.

Sullivan, R., J. Abplanalp, E. Zvolanek, and J. Brown, 2016. Visual Resource Analysis for Solar Energy Zones in the San Luis Valley. Environmental Science Division, Argonne National Laboratory, Argonne, Illinois and San Luis Valley Public Field Office, U. S. Department of the Interior, Bureau of Land Management. Prepared for U.S. Bureau of Land Management, Colorado State Office. January.

Taos Valley Acequia Map, n.d. Map showing acequias in Taos Valley

Taylor, Andrew M., 1999. Guide to the Geology of Colorado. Cataract Lode Mining Company, Golden, Colorado.

Theobald, D.M., 2013. “A general model to quantify ecological integrity for landscape assessments and US application,” Landscape Ecology 28:1859-1874.

Tiller, V.E., 1983, “Jicarilla Apache,” pp. 440 - 461 in Handbook of North American Indians, 33 Vol. 10, Southwest, A. Oritz (editor), Smithsonian Institution, Washington, D.C.

Time, 1941. New Mexico: End of the Chili Line. Time Magazine. Available at: http://content.time.com/time/magazine/article/0,9171,766037,00.html. Accessed November 10, 2015.

Turquoise Museum, 2015. Villa Grove Mine. Website URL:

http://turquoisemuseumcom.siteprotect.net/wordpress/sample-page/colorado-mines/villa-grovemine/. Accessed April 27, 2015.

Two Bears, Davina, 2012. “Navajo Traditional History,” Native Voices on the Colorado River Tribal Series. Available at: https://nativevoicesonthecolorado.wordpress.com/resources/.

Accessed November 10, 2015.

UNESCO, 2012. Camino Real de Tierra Adentro. Website URL: http://whc.unesco.org/en/list/1351. Accessed April 27, 2015.

U.S. Climate Data, 2016a. “Taos, New Mexico.” Available at: http://www.usclimatedata.com/climate/taos/new-mexico/united-states/usnm0314. Accessed March 2016.

U.S. Climate Data, 2016b. “Espanola, New Mexico.” Available at: http://www.usclimatedata.com/climate/espanola/new-mexico/united-states/usnm0435. Accessed March 2016. 
USDA (U.S. Department of Agriculture), 2014. "History and Culture of the San Luis Valley Area.” Available at: http://www.fs.usda.gov/detail/riogrande/learning/historyculture/?cid=stelprdb5172158. Accessed March 2016.

USDOI (U.S. Department of the Interior), 2010. Secretarial Order 3289, Addressing the Impacts of Climate Change on America's Water, Land, and Other Natural and Cultural Resources. September 14. Available at: http://www.blm.gov/pgdata/etc/medialib/blm/wy/programs/ science.Par.90488.File.dat/SO_3289.pdf.

USDOI, 2013. Secretarial Order 3330, Improving Mitigation Policies and Practices in the Department of the Interior. October 31. Available at: http://www.doi.gov/news/upload/Secretarial-Order-Mitigation.pdf.

USFWS (U.S. Fish and Wildlife Service), 2012. Draft Environmental Assessment and Land Protection Plan, San Luis Valley Conservation Area, Colorado and New Mexico. Available at http://www.fws.gov/mountain-prairie/planning/lpp/co/slv/documents/slv_lppdraft_all.pdf. Accessed December 18, 2014.

USFWS, 2014. About the San Luis Valley National Wildlife Refuge Complex. Website URL http://www.fws.gov/refuge/Alamosa/About_the_Complex.html, Accessed December 18, 2014.

USFWS, 2015. Baca National Wildlife Refuge. Website URL:

http://www.fws.gov/refuge/Baca/about/about_the_refuge.html.html. Accessed, September 9, 2015.

Valdez, A., G. Raymond, K. Juul, M. Ikle, S. Bedford, S. Daneels, 2003. The Village of Los Pinos: A Reconnaissance Survey. Prepared by: The University of New Mexico School of Architecture and Planning, Albuquerque, New Mexico. Prepared for The New Mexico State Historic Preservation Office. Spring.

Walston, L.J., H.M. Hartmann, K.L. Wescott, E.A. Zvolanek, K.E. Rollins, and L.R. Fox, 2016. San Luis Valley - Taos Plateau Level IV Ecoregion Landscape Assessment, Draft Final Report. ANL/EVS-16/5. Environmental Science Division, Argonne National Laboratory, Argonne Illinois. Prepared for U.S. Department of the Interior, Bureau of Land Management, Colorado State Office and New Mexico State Office.

Wells, S. J., 2008, Archaeological Inventory and National Register Evaluation for the Baca Land 25 Exchange La Jara Parcels Conejos County, Colorado, prepared by the Western Archaeological and Conservation Center, Tucson, Ariz., and Fort Lewis College, Durango, Colo., for the National Park Service, Denver, Colo., the Bureau of Land Management, Lakewood, Colo., and the U.S. Fish and Wildlife Service, Lake, Colo., WACC Publications in Anthropology 101, Nov.

White, D., 2005. Seinanyédi: An Ethnographic Overview of Great Sand Dunes National Park and Preserve. Prepared for the National Park Service. Applied Cultural Dynamics, Sante Fe, New Mexico. 
Winthrop, Kate, 2014. Cultural Resources and the BLMs Landscape Approach: Discussion Paper. April.

Woolmer, G., S.C. Trombulak, J.C. Ray, P.J. Doran, M.G. Anderson, R.F. Baldwin, A. Morgan, and E.W. Sanderson, 2008. "Rescaling the human footprint: a tool for conservation planning at an ecoregional scale,” Landscape and Urban Planning 87 (1):42-53.

Wyckoff, William, 1999. Creating Colorado: Making of a Western American Landscape 18601940. Ann Arbor: Edward Brothers, Inc. 
Final SLV-TP Landscape-Level

October2016

Cultural Heritage Values and Risk Assessment

Page Intentionally Left Blank 


\section{APPENDIX A:}

MANAGEMENT QUESTIONS 
Final SLV-TP Landscape-Level

October2016

Cultural Heritage Values and Risk Assessment

Page Intentionally Left Blank 


\section{APPENDIX A:}

\section{MANAGEMENT QUESTIONS}

This appendix presents the assessment of management questions (MQs) identified by the BLM Interdisciplinary Team throughout the course of the San Luis Valley - Taos Plateau Landscape Assessment. A total of 56 MQs were identified (see Walston et al. 2016, Appendix A, Table A-1), seven of which are related to human and cultural elements. The latter are presented again below in Table A-1. As discussed in Section 1.2.1, only six of the seven MQs (MQI1MQI6) were evaluated for the Landscape-Level Cultural Heritage Values and Risk Assessment and that evaluation is presented in this appendix.

\section{Table A-1. Management Questions: Human and Cultural Elements}

\begin{tabular}{ll} 
MQI1 & $\begin{array}{l}\text { Where do areas of cultural resource management and protection occur (National } \\
\text { Monuments, ACECs, National Historic Landmarks, World Heritage Areas, } \\
\text { Scenic and Historic Byways, etc.)? }\end{array}$ \\
\hline MQI2 & $\begin{array}{l}\text { Where are known historic properties, traditional cultural properties, and sacred } \\
\text { sites and landscapes? }\end{array}$ \\
\hline MQI3 & What are the traditional cultural land use patterns? \\
\hline MQI4 & $\begin{array}{l}\text { Where are known historic properties, traditional cultural properties, and sacred } \\
\text { sites vulnerable to change agents? }\end{array}$ \\
\hline MQI5 & $\begin{array}{l}\text { Where are high potential areas or high density areas for historic properties that } \\
\text { address the highest priority research goals? }\end{array}$ \\
\hline MQI6 & $\begin{array}{l}\text { Where is cultural landscape connectivity vulnerable to change agents (human } \\
\text { development, fire, invasive species, and climate change)? }\end{array}$ \\
\hline MQI7 & $\begin{array}{l}\text { Where are sensitive socioeconomic populations, and how are they affected by } \\
\text { change agents? }\end{array}$ \\
\hline
\end{tabular}


Final SLV-TP Landscape-Level

October2016

Cultural Heritage Values and Risk Assessment

Page Intentionally Left Blank 


\section{A.1 MQI1: Where do areas of cultural resource management and protection occur?}

The San Luis Valley - Taos Plateau study area covers 9,786 mile² (6,263,015 acres). Approximately $10 \%$ of the study area contains defined areas of designated cultural resource management and protection. Over $50 \%$ of the study area is federally managed by the BLM, NPS, USFS, and USFWS, providing some additional consideration for cultural resources through compliance with the National Historic Preservation Act. Finally, 69\% of the study area is part of a National Heritage Area (NHA), either the Sangre de Cristo NHA in Colorado or the Northern Rio Grande NHA in New Mexico. Because the NHAs overlap with many of the other federal designations as well as private lands, the NHA land percentage is presented here separately. The NHAs are congressionally designated areas. The NHA program supports large-scale, community-driven initiatives to support historic preservation, conservation, recreation, heritage tourism, and education, and is administered by the NPS, but the land is not a national park unit (no ownership or land use controls) (NPS 2016 - https://www.nps.gov/heritageareas/FAQ/). Tables A.1-1 and A.1-2 provide a listing of areas where cultural resource management and protection occur within the study area. These areas are also shown in Figure A.1-1.

Table A.1-1. Specially Designated Areas of Cultural Resource Management and Protection

\begin{tabular}{|l|c|c|}
\hline \multicolumn{1}{|c|}{ Specially Designated Area } & Acres in Study Area & \% of Study Area \\
\hline National Monuments & 310,529 & 4.96 \\
\hline National Historic Landmarks & $12^{*}$ & 0.0 \\
\hline World Heritage Areas & 16 & 0.0 \\
\hline Scenic and Historic Byways & $1,520^{*}$ & .02 \\
\hline National Register Sites/Districts & $1,713^{*}$ & .03 \\
\hline National Scenic and Historic Trails & $2,449^{*}$ & .04 \\
\hline National Historic Parks & 0 & 0.0 \\
\hline National Parks and Preserves & 149,700 & 2.39 \\
\hline $\begin{array}{l}\text { National Conservation Areas and } \\
\text { Conservation Easements }\end{array}$ & 166,185 & 2.65 \\
\hline $\begin{array}{l}\text { Areas of Critical Environmental } \\
\text { Concern (Cultural, Historical, and } \\
\text { Paleontological) }\end{array}$ & 3,901 & .06 \\
\hline
\end{tabular}

*Estimated acreage from point data and linear features

Table A.1-2. Federally Administered Lands and National Heritage Areas

\begin{tabular}{|l|c|c|}
\hline \multicolumn{1}{|c|}{ Federally Administered Lands } & Acres in Study Area & \% of Study Area \\
\hline Bureau of Land Management & 934,523 & 14.91 \\
\hline U.S. Forest Service & $2,077,282$ & 33.15 \\
\hline U.S. Fish and Wildlife Service & 112,357 & 1.79 \\
\hline National Park Service & 149,700 & 2.39 \\
\hline & & \\
\hline National Heritage Areas & $4,343,216$ & 69.34 \\
\hline Sangre de Cristo NHA & $2,168,505$ & 34.62 \\
\hline Northern Rio Grande NHA & $2,174,711$ & 34.72 \\
\hline
\end{tabular}




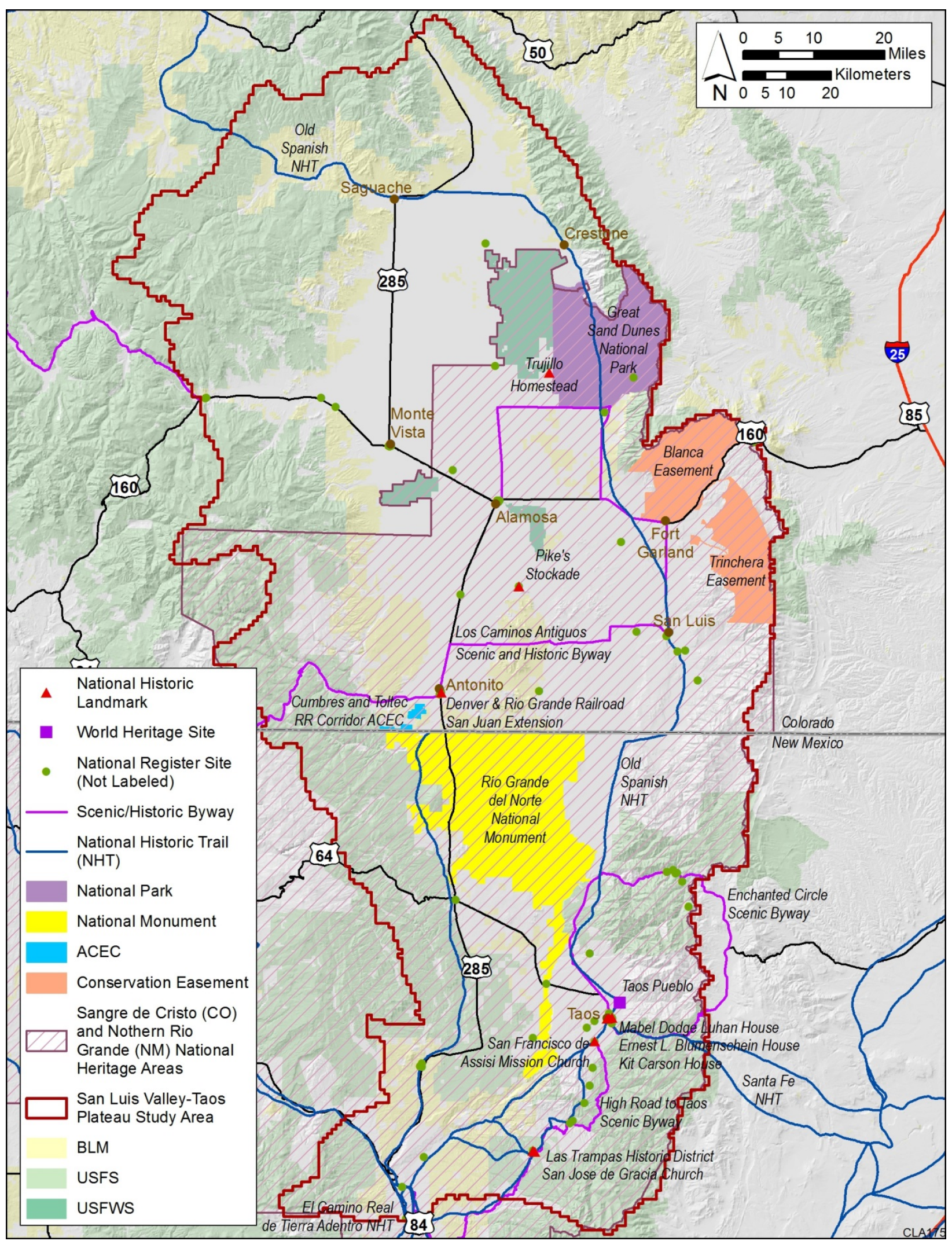

Figure A.1-1. Areas of Cultural Resources Management and Protection 


\section{A.2 MQI2: Where are known historic properties, traditional cultural properties, and sacred sites and landscapes?}

To determine the location of all known cultural resources within the study area, data were collected on known historic and prehistoric properties, traditional cultural properties, sacred sites and cultural landscapes, including the National Heritage Areas. As discussed throughout the main document, data were derived from a review of historic, archaeological, and contemporary GIS and ethnographic data; reports and management plans for various resources; and discussions with the peer-review workshop team. These resources were placed into one of seven cultural conservation elements and spatially displayed in GIS. Figure A.2 depicts all of the known cultural resources within the study area and identifies areas where cultural resources have not been identified. This figure represents the maximum extent or union model as presented in Figure 4-1a. 


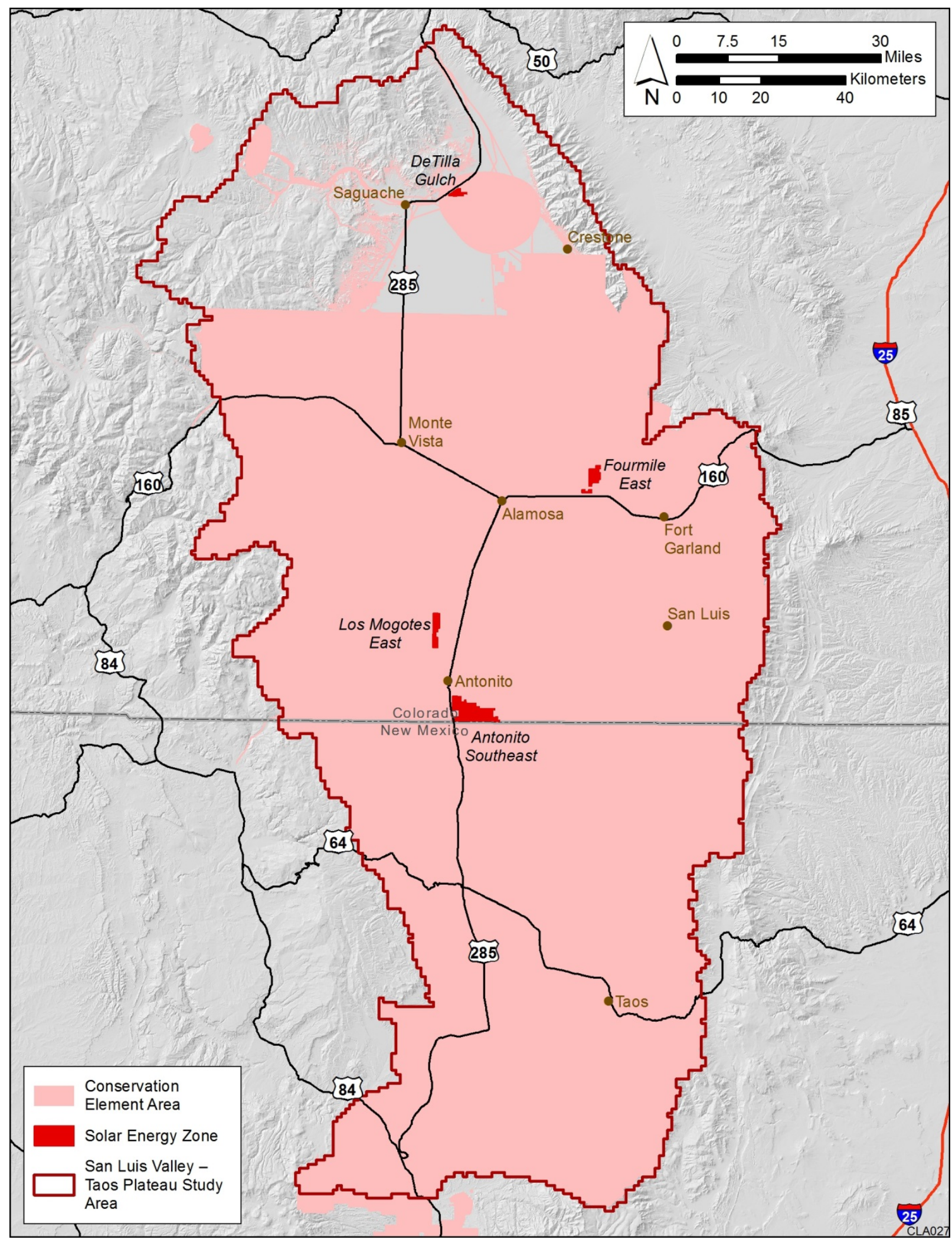

Figure A.2-1. Locations of Known Cultural Resources within the Study Area 


\section{A.3 MQI3: What are the traditional cultural land use patterns?}

This management question can be addressed by looking at the current distribution of known resources across the landscape within each cultural conservation element or for any combination of cultural conservation elements. For example, the known distribution of places of traditional cultural importance to tribes and eligible prehistoric properties could provide a better picture of the traditional land use of prehistoric Native American groups than just looking at one of the cultural conservation elements on its own. Appendix B provides information on the current distribution of known resources for each conservation element individually.

While each cultural conservation element has its own unique pattern of land use, there are many areas of overlap among the elements. The cultural resources of concern - coincidence model depicts the current distribution of known resources across the landscape for all conservation elements combined. For example, if a resource was identified as a resource of importance in more than one cultural conservation element, it received a higher score than if it appeared in only one cultural conservation element. Areas that appear in one or more of the cultural conservation elements appear darker than those that only appear in one. This model is most efficient in identifying areas with the highest level of use and/or significance for prehistoric, historic, and contemporary populations. As shown in Figure A.3-1, many high use areas are influenced by landscape features such as mountain peaks, mountain passes, and water sources. Other traditional high-use areas include travel corridors and agricultural areas. 


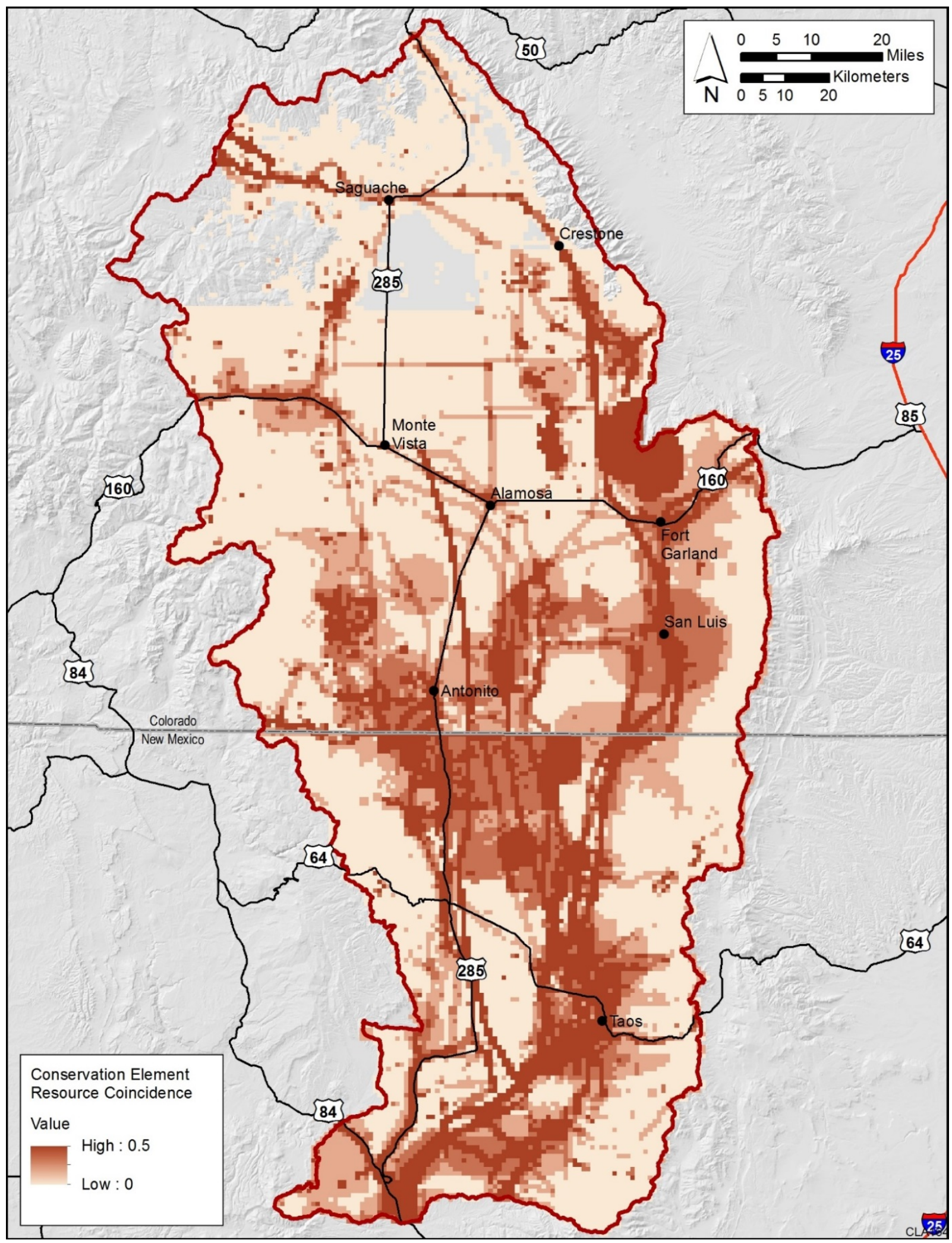

Figure A.3-1. Cultural Resources of Concern - Coincidence Model (Current distribution of known cultural resources with all cultural conservation elements combined) 


\section{A.4 MQI4: Where are the known historic properties, traditional cultural properties, and sacred sites vulnerable to change agents?}

This management question can be addressed using the cultural risk model that was developed for the study area.

Risk to cultural resources as a result of future change agents was calculated using the modeling of likely future conditions for areas projected to experience climate change, wildfire, and spread of invasive species, as well as the added areas of anticipated future new development. Each of the change agents was weighted equally to assess overall risk to cultural conservation elements. The future conditions for climate change, wildfire, spread of invasive species, and new development are shown in Figures A.4-1 through A.4-4, respectively. The final output of this model is shown in Figure A.4-5.

As shown in Figure A.4-5, areas of highest risk to one or more future change agents appear to be located around the peripheral of the study area near the foothills of the surrounding mountains, along travel corridors, and near populated areas. The cultural risk model is further discussed in Section 4.2.

The effect of current and future trends of change agents on cultural resources was evaluated individually by cultural conservation element. The reader is referred to Appendix B for individual assessments. 


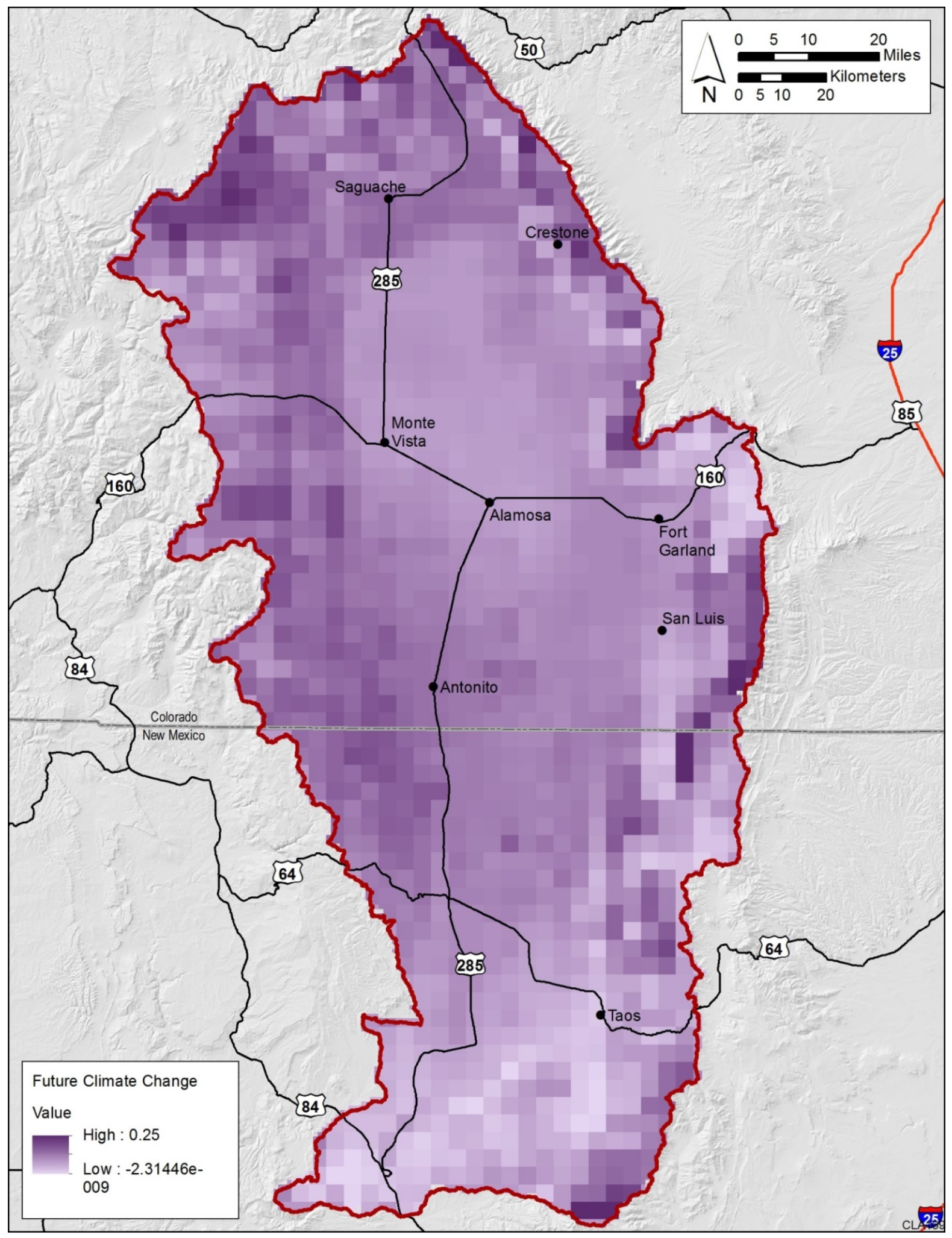

Figure A.4-1. Potential Future Trend of Climate Change in the Study Area 


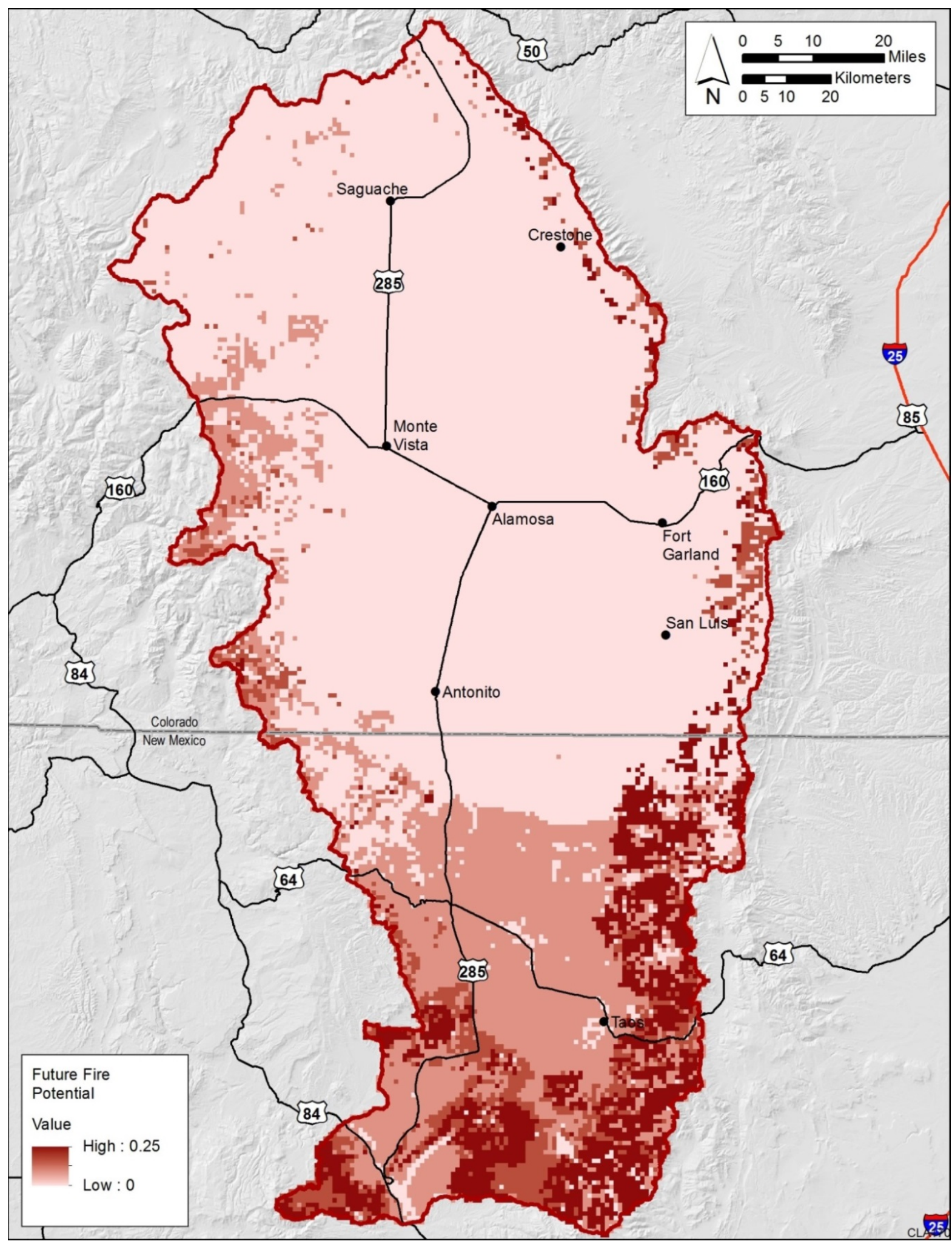

Figure A.4-2. Potential Future Trend of Wildfire in the Study Area 


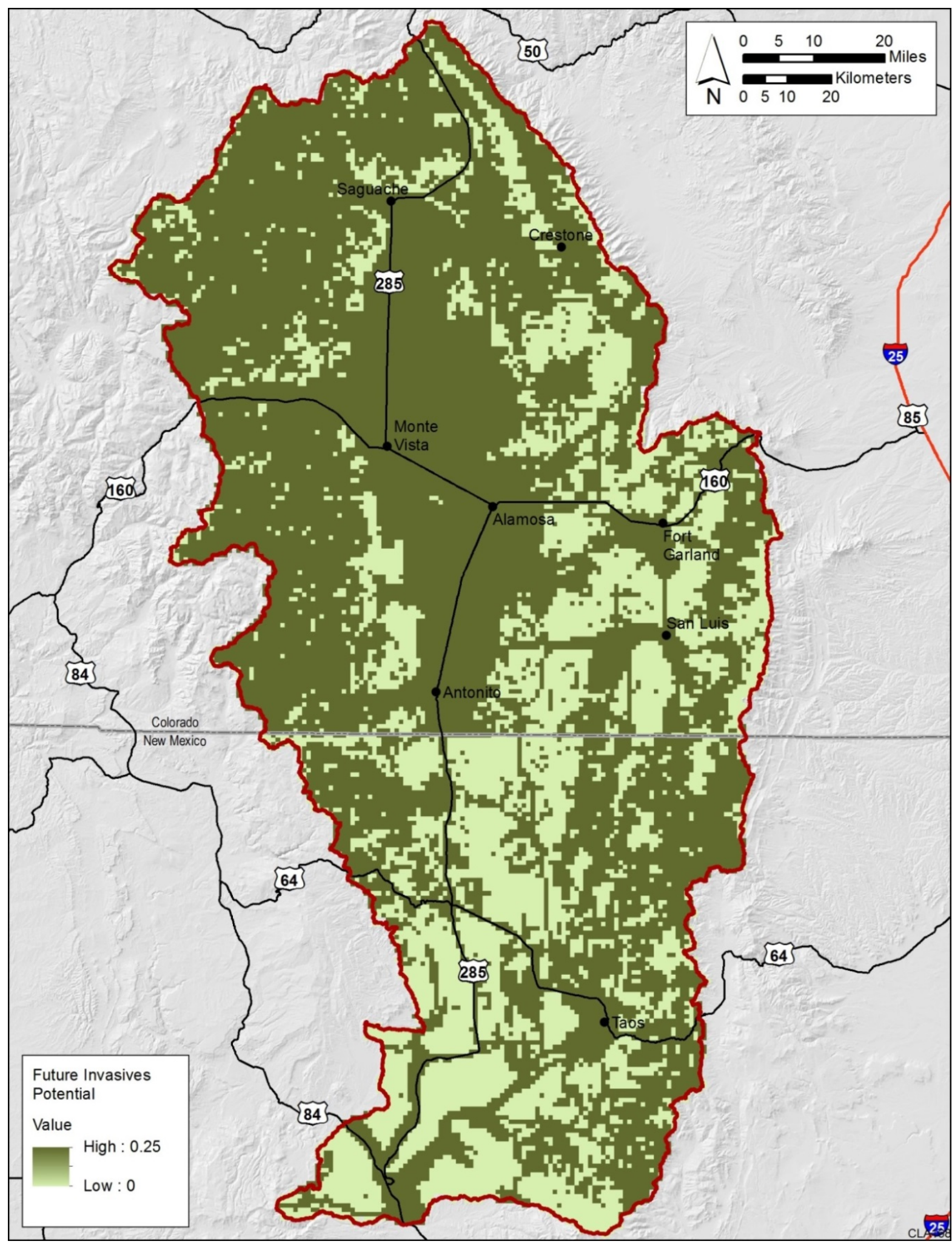

Figure A.4-3. Potential Future Trend of Invasive Species in the Study Area 


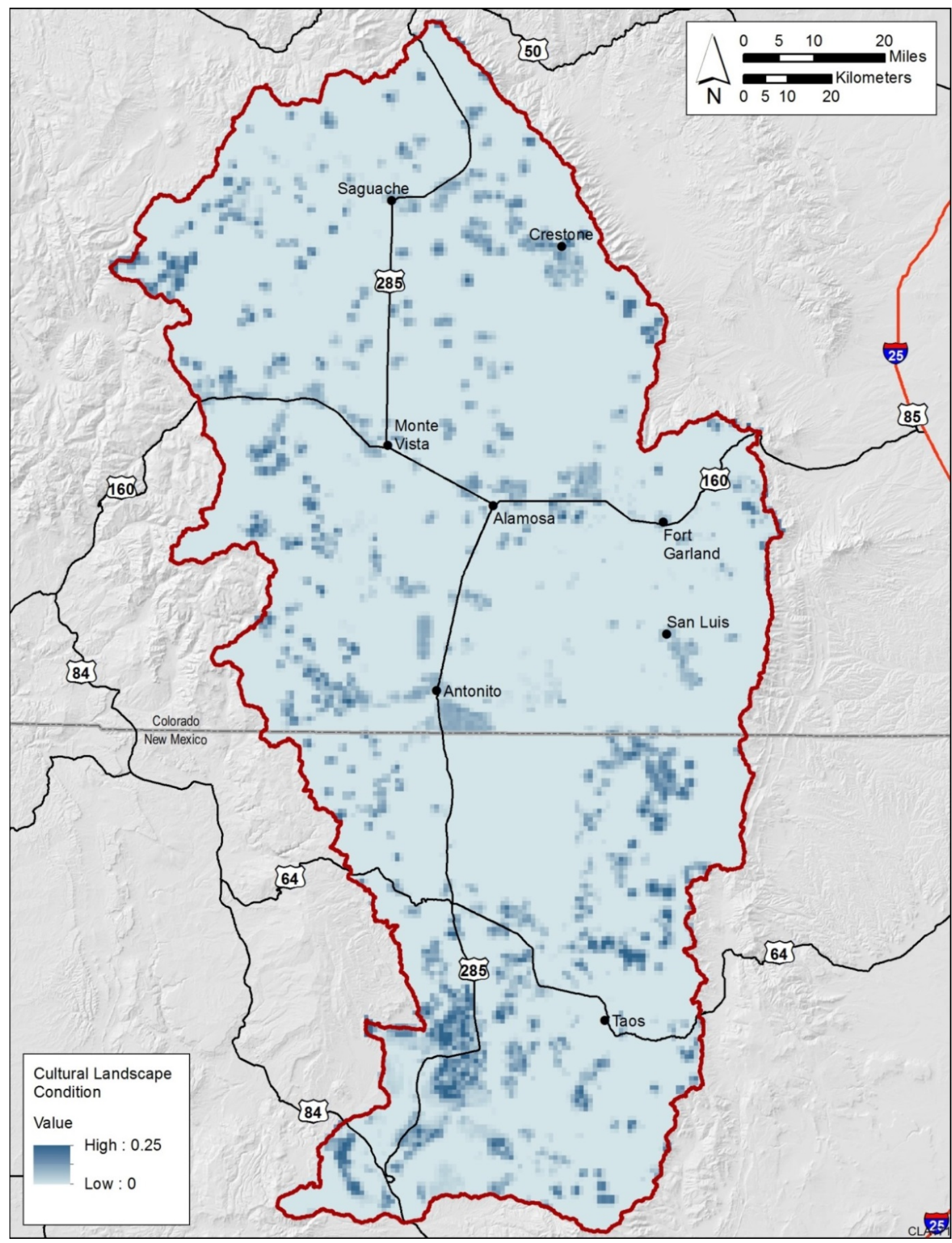

Figure A.4-4. Potential Future Trend in Human Development 


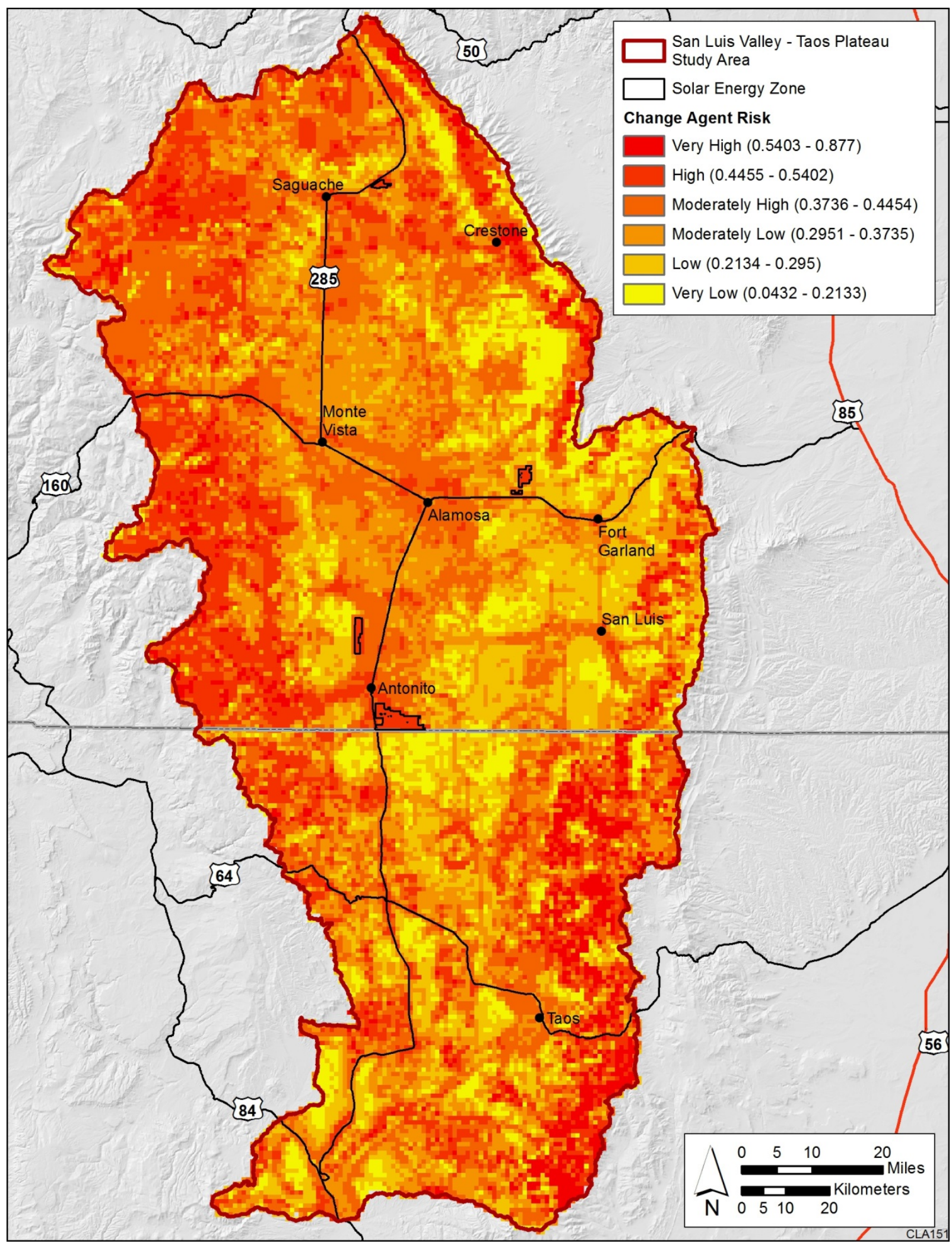

Figure A.4-5. Risk as a Result of Future Trends in Change Agents within the Study Area 


\section{A.5 MQI5: Where are high potential areas or high density areas for historic properties that address the highest priority research goals?}

Section 6.0 (Lessons Learned and Future Considerations) of the Cultural Heritage Values and Risk Assessment identified the definition of high priority research goals as a recommended future action. Since high priority research goals have not yet been developed, this management question can be partially addressed using the mitigation potential model.

The cultural resource value model combined three factors to produce the cultural value of a given area: (1) presence of resources (using the coincidence output or the scoring output), (2) viewshed value, and (3) archaeological research potential. Inputs were weighted as follows: presence of resource (50\%); viewshed value (25\%); archaeological research potential (25\%). The final output of this model (using the coincidence output) is shown in Figure A.5-1.

Risk to cultural resources was calculated using the modeling of likely future conditions for areas projected to experience climate change, wildfire, and spread of invasive species, as well as the added areas of anticipated future new development. Each of the change agents was weighted equally to assess overall risk to cultural conservation elements. The final output of this model is shown in Figure A.5-2.

The mitigation potential models combined the cultural resource value - Coincidence output with the overall cultural resource risk model for the study area to determine areas with cultural resources that have high and very high cultural resource value and areas of land with high and very high risk from future change agents (High Value/High Risk) (Figure A.5-3) and cultural resources with high and very high cultural resource value with areas of land that have low and very low risk from future change agents (High Value/Low Risk) (Figure A.5-4).

Areas that have higher cultural value coupled with high risk should be evaluated for their potential to address priority research goals when these are determined. Areas that have high cultural value coupled with low risk are candidates for long-term conservation and protection. When research goals have been prioritized, these areas can be assessed for their ability to answer high priority research questions or address high priority conservation goals.

To fully answer this management question, the cultural risk model output could be combined with the archaeological research potential model. The archaeological research potential model already identifies areas that may offer opportunities for future research. Coupled with the cultural risk model, the output would depict areas of high archaeological research potential and high risk which can be further prioritized for opportunities not only for research in the near-term, but also opportunities to create possible conservation areas to protect the resources in the future and/or to develop mitigation projects before the resource is adversely affected, including possible data recovery designed on the basis of the developed research goals. 


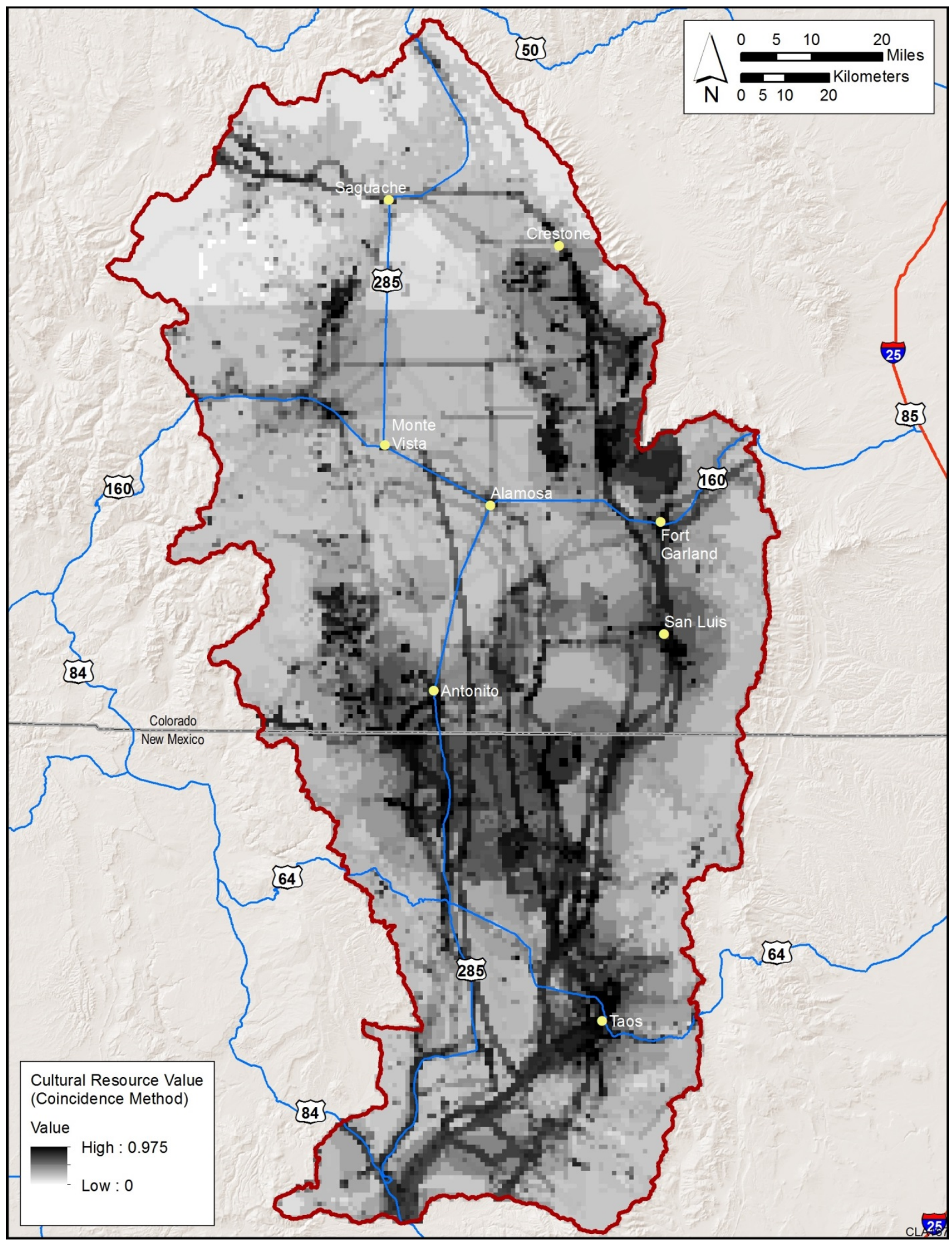

Figure A.5-1. Cultural Resource Values of Cultural Conservation Elements in the Study Area 


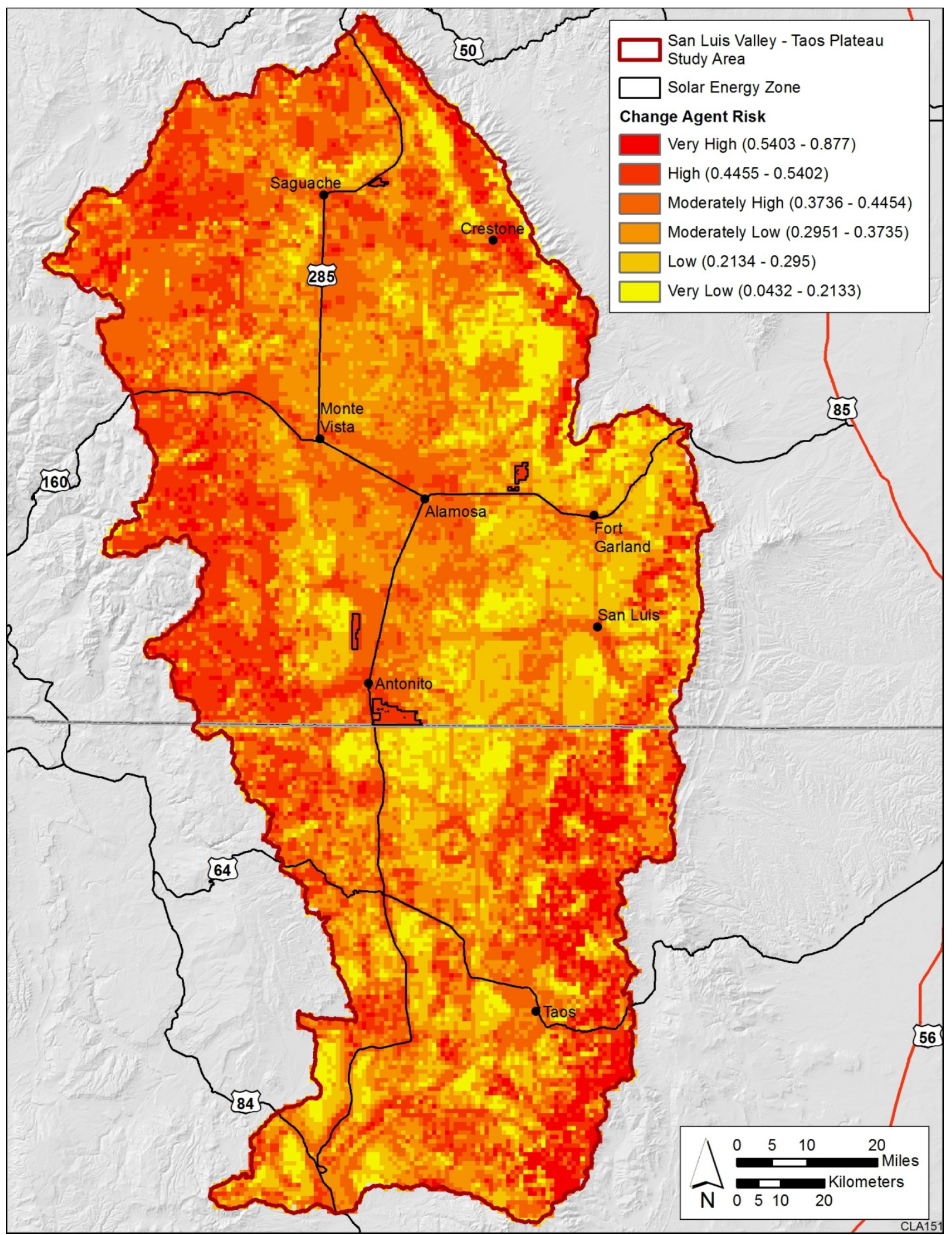

Figure A.5-2. Risk as a Result of Future Trends in Change Agents within the Study Area 


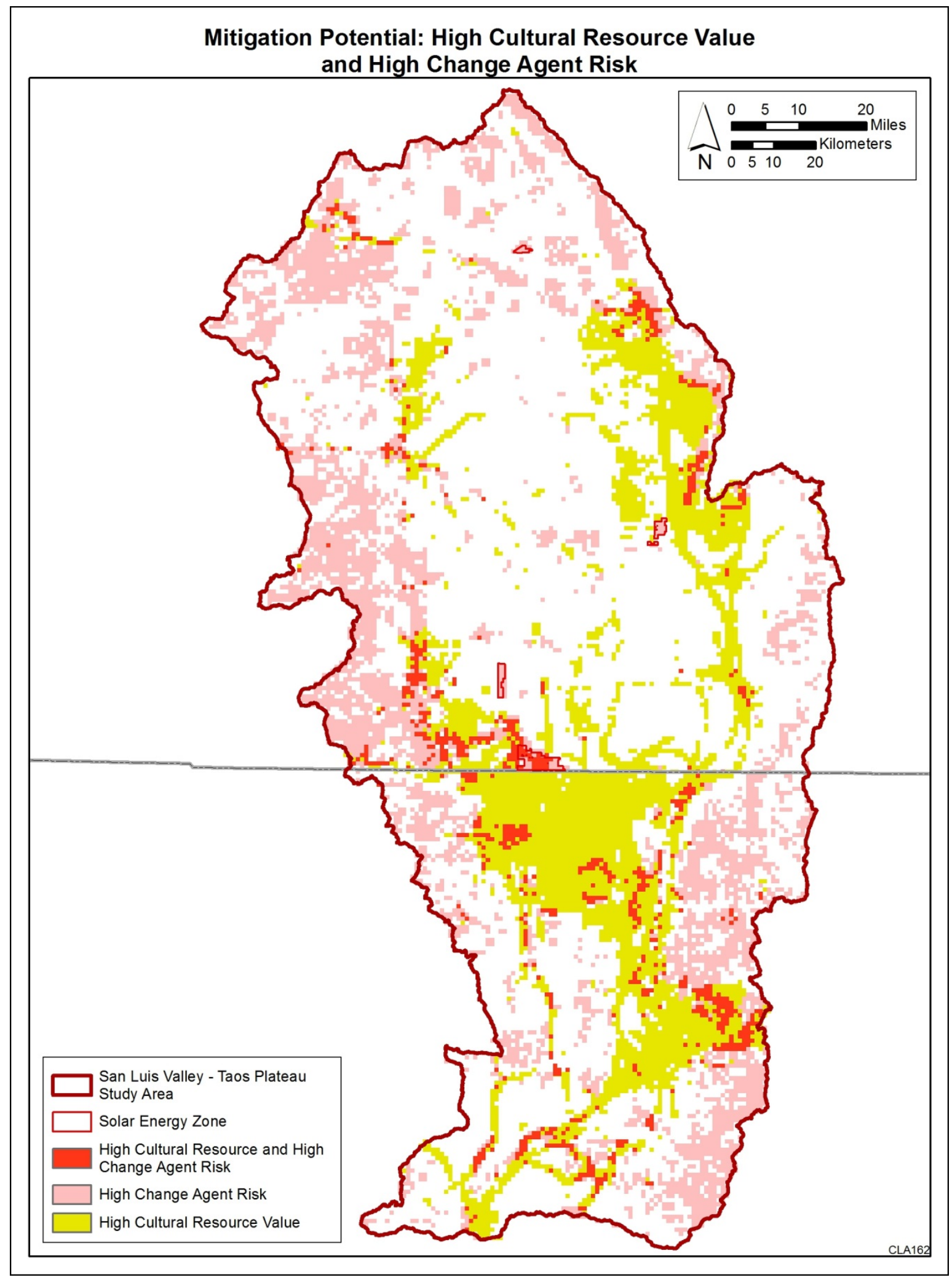

Figure A.5-3. Areas of High Cultural Value and High Change Agent Risk 


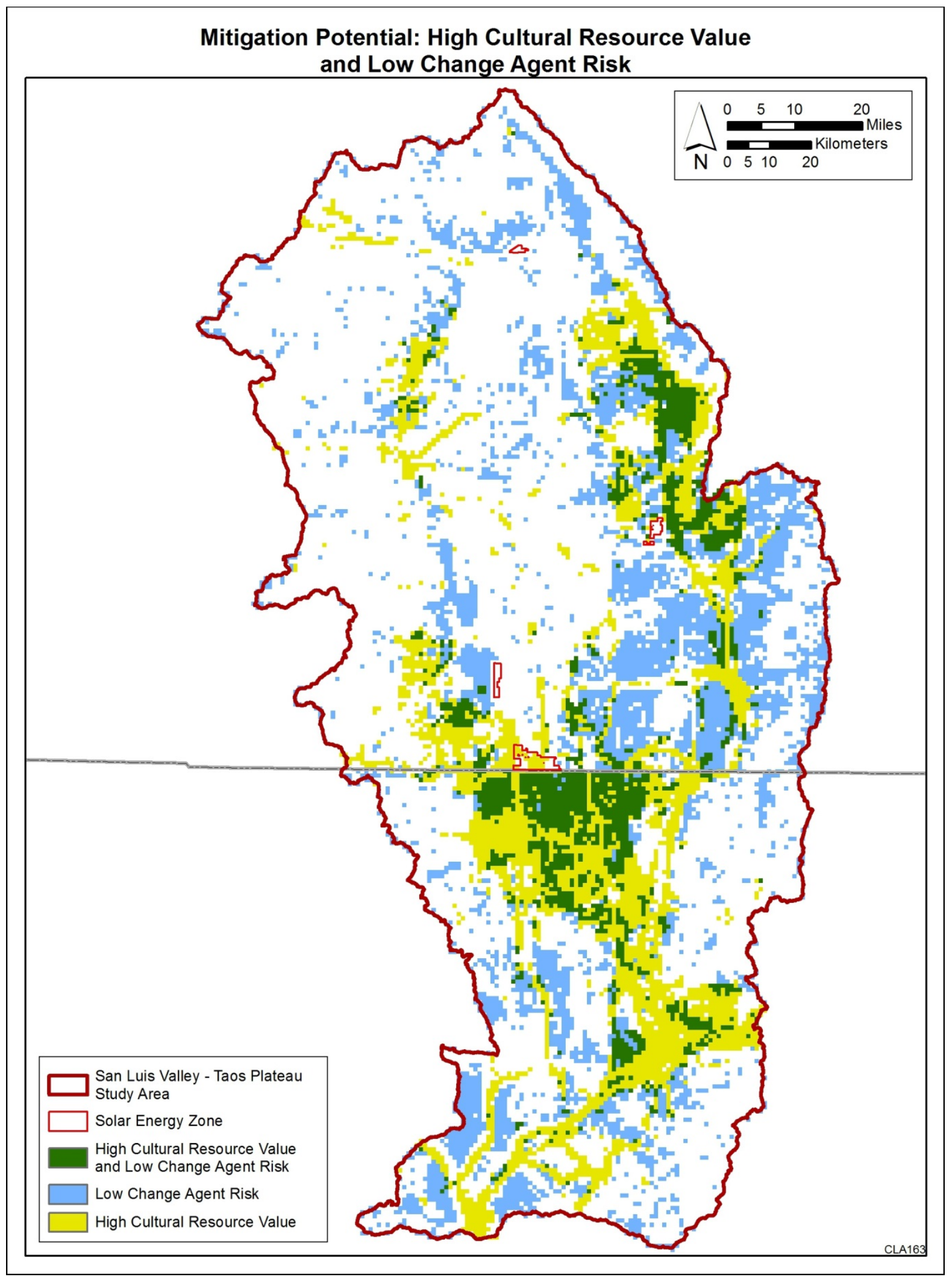

Figure A.5-4. Areas of High Cultural Value and Low Change Agent Risk 
Final SLV-TP Landscape-Level

October2016

Cultural Heritage Values and Risk Assessment

Page Intentionally Left Blank 


\section{A.6 MQI6: Where is cultural landscape connectivity vulnerable to change agents (human development, fire, invasive species, climate change)?}

This management question can be addressed by the mitigation potential model. As stated in Section A.5, the high value/high risk scenario for the mitigation potential model combined the cultural resources value coincidence output with the overall cultural risk model for the study area. As shown in Figure A.6-1, areas shown in red depict the overlap of cultural resources with high and very high cultural resource value and areas of land with high and very high risk from future change agents.

Vulnerability appears most prominent along portions of present day travel corridors such as US Route 285 and US Route 60 between Tres Piedras and Espanola, New Mexico, and near populated cities such as the towns of Antonito and Del Norte, Colorado and Tres Piedras and Taos, New Mexico and the area in between the Ohkay Ohwingeh and Picuris Pueblos in the southern portion of the study area. 


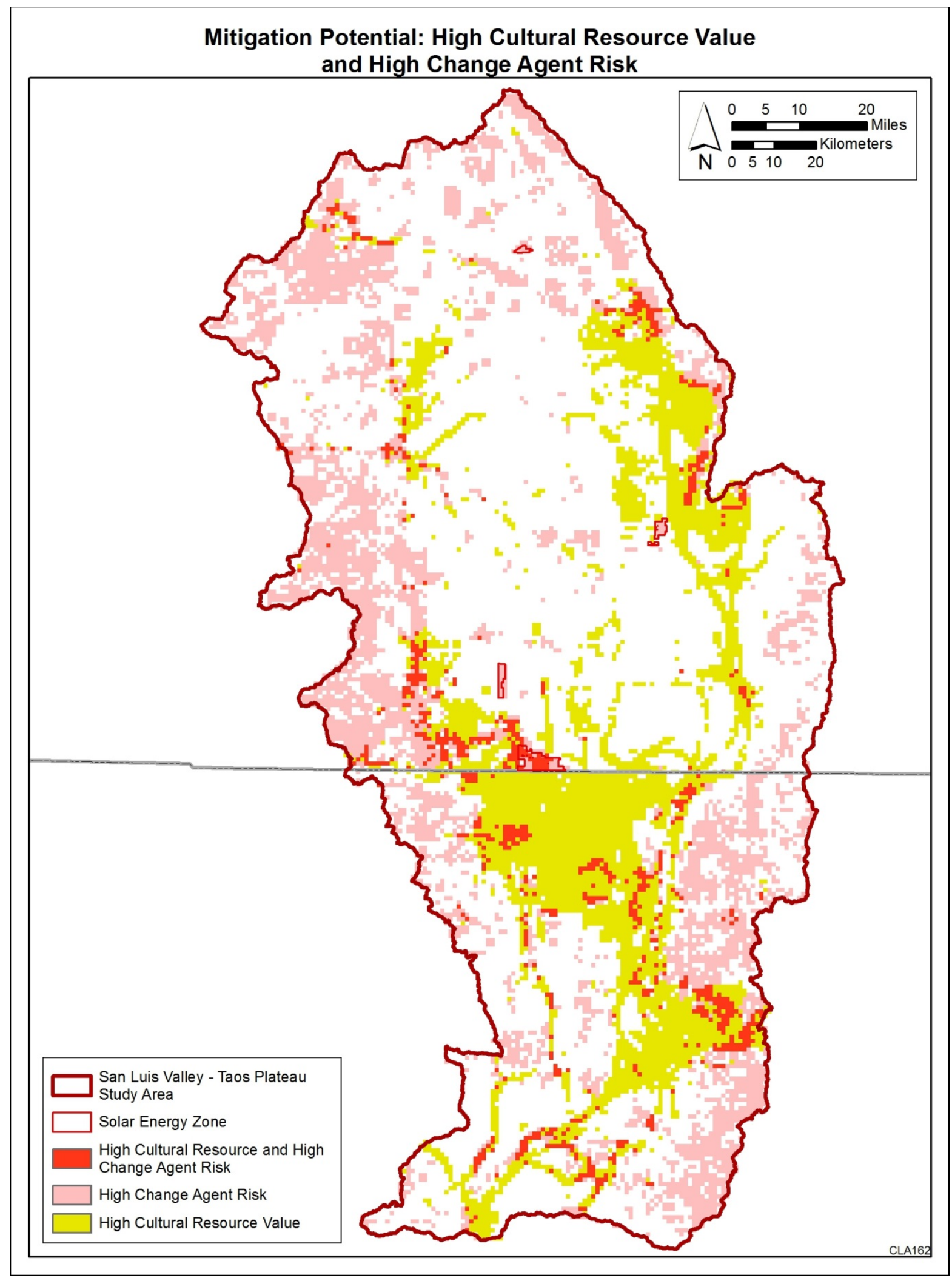

Figure A.6-1. Areas of High Cultural Value and High Change Agent Risk 


\section{APPENDIX B:}

\section{CULTURAL CONSERVATION ELEMENTS}


Final SLV-TP Landscape-Level

October2016

Cultural Heritage Values and Risk Assessment

Page Intentionally Left Blank 


\section{APPENDIX B:}

\section{CULTURAL CONSERVATION ELEMENTS}

A total of seven cultural conservation elements were included for evaluation in this cultural heritage values and risk assessment. The specific properties or property types included with each cultural conservation element are presented below in Table B-1. The process for identifying, screening, and selecting conservation elements for the Landscape Assessment is described in the Phase I Report (Argonne National Laboratory 20144).

Table B-2 summarizes the current and future conditions of the cultural conservation elements with respect to their intersections with change agents.

The spatial distributions and current and future conditions of these CEs are presented in the sections below.

4 Argonne National Laboratory, 2014, San Luis Valley - Taos Plateau Level IV Ecoregion Landscape Assessment, Phase I Report and Phase II Work Plan. Prepared for the Bureau of Land Management. August. 
Table B-1. Cultural Conservation Elements Evaluated in this Cultural Heritage Values and Risk Assessment

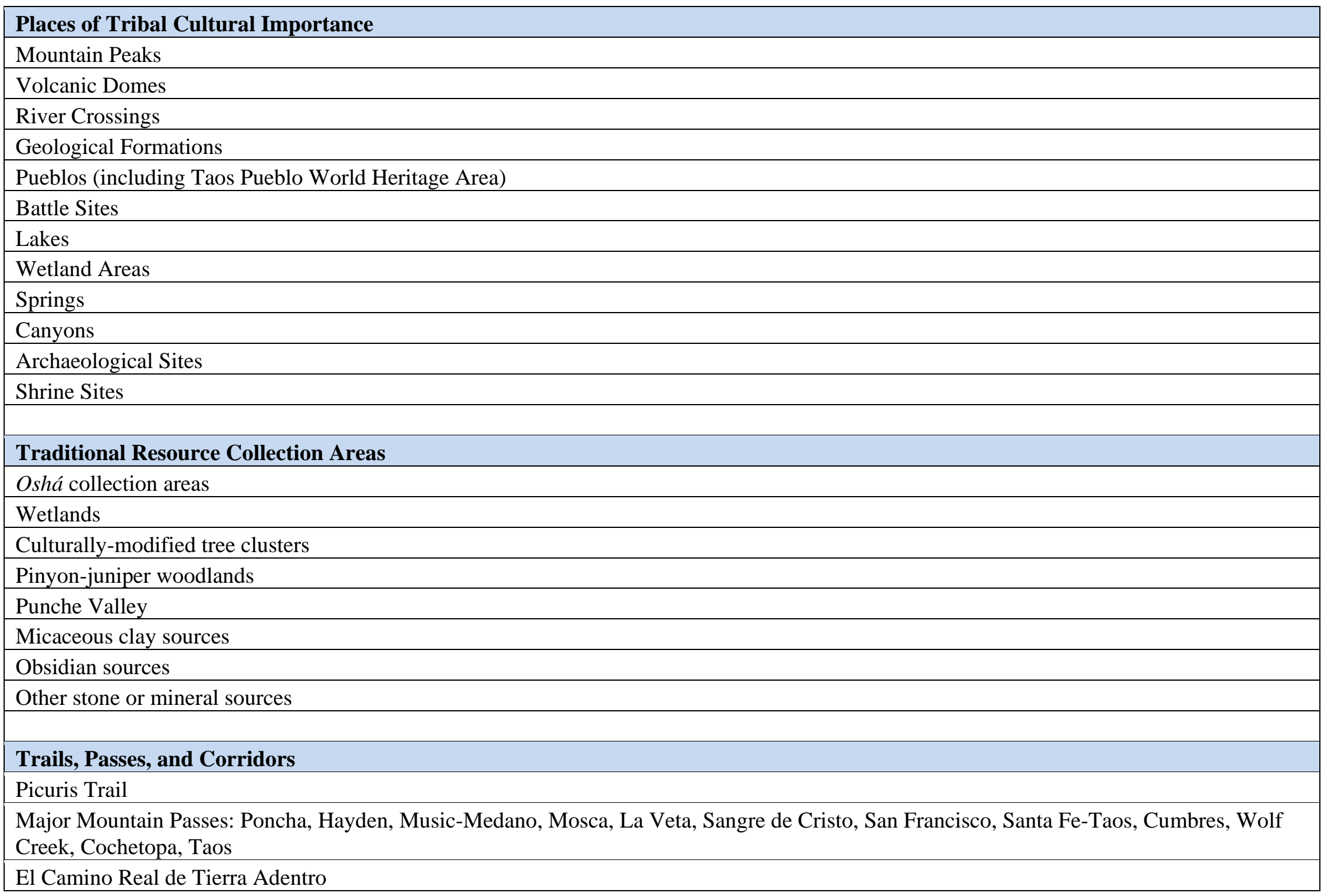


Table B-1. (Cont.)

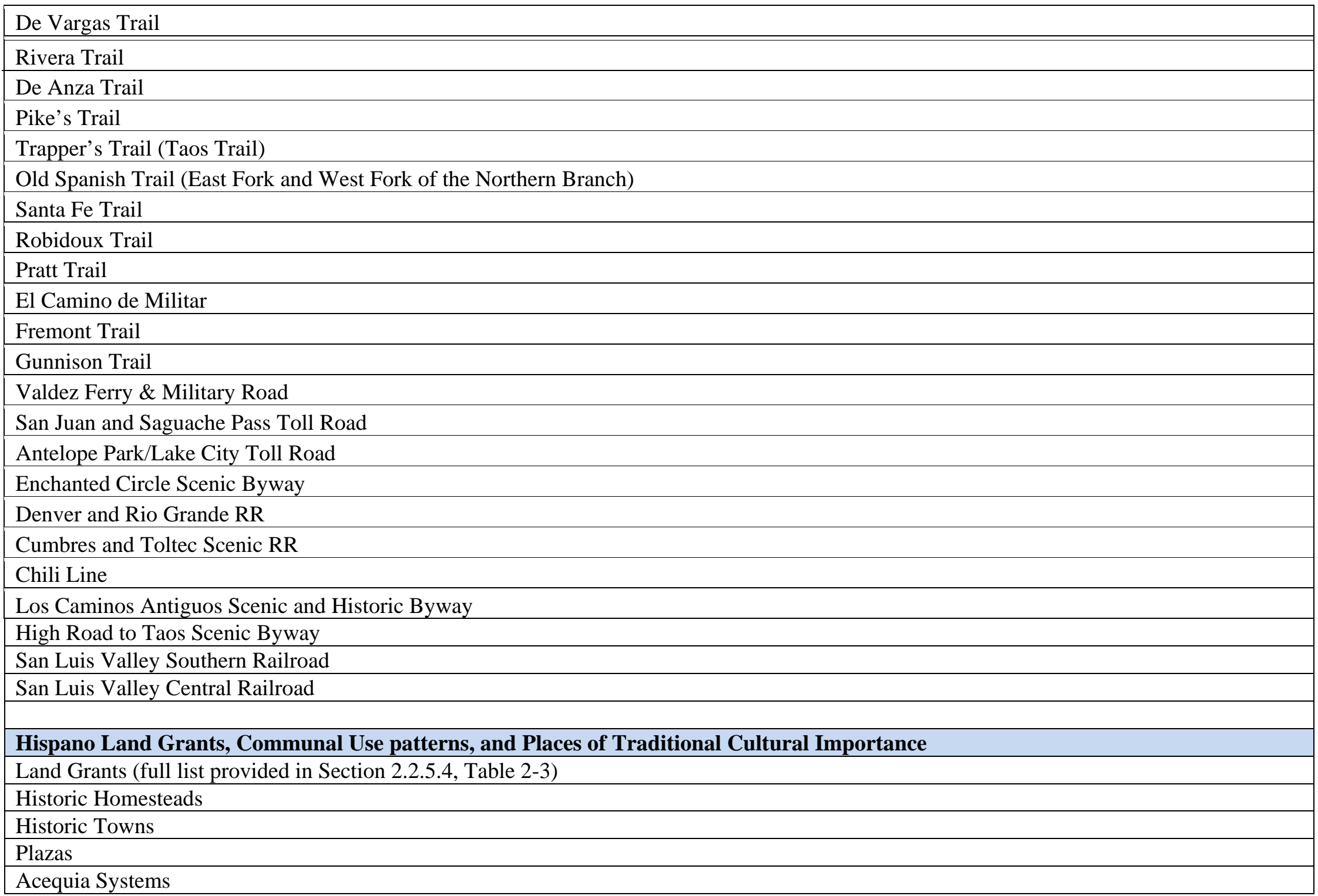


Table B-1. (Cont.)

Historic collection areas

Contemporary collection areas

Historic buildings and archaeological sites associated with Spanish and Mexican history

Long-lot communities

\section{Paleontology}

Fossil localities

\section{Eligible Prehistoric Properties}

Biedell Archaeological District

La Jara Archaeological District

Open architectural sites

Open camps

Sheltered camps

Open lithic sites

Lithic scatters

Ceramic scatters

Rock art

Human burial sites

Rio Grande del Norte National Monument

\section{Eligible Historic Properties}

Military Forts

Historic homes and buildings

Cemeteries

Historic homesteads

Townsites

Mining cabins and complexes

Rock alignments

Historic farm buildings

Historic agricultural and pasture lands

Historic Campsites 
Table B-1. (Cont.)

Pikes Stockade NHL

Trujillo Homestead NHL

Denver and Rio Grande RR San Juan Extension NHL

Mabel Dodge Luhan House NHL

Kit Carson House NHL

Ernest L. Blumenschein House NHL

Las Trampas Historic District NHL

San Jose de Gracia Church NHL

Rio Grande del Norte National Monument

Cumbres and Toltec Scenic RR 
Table B-2. Summary of Conservation Element Current and Future Potential Conditions. ${ }^{5}$

\begin{tabular}{|c|c|c|c|c|c|c|c|c|c|c|}
\hline $\begin{array}{l}\text { Conservation } \\
\text { Element } \\
\end{array}$ & $\begin{array}{l}\text { Current } \\
\text { Cultural } \\
\text { Landscape } \\
\text { Condition } \\
\end{array}$ & $\begin{array}{l}\text { Future } \\
\text { Cultural } \\
\text { Landscape } \\
\text { Condition } \\
\end{array}$ & $\begin{array}{l}\text { Current } \\
\text { Human } \\
\text { Development }\end{array}$ & $\begin{array}{l}\text { Future } \\
\text { Human } \\
\text { Development }\end{array}$ & $\begin{array}{l}\text { Current } \\
\text { Climate } \\
\text { Change } \\
\text { (Relative to } \\
\text { Historic) } \\
\end{array}$ & $\begin{array}{l}\text { Potential for } \\
\text { Future } \\
\text { Climate } \\
\text { Change } \\
\end{array}$ & $\begin{array}{l}\text { Current Fire } \\
\text { Density } \\
\end{array}$ & $\begin{array}{l}\text { Future } \\
\text { Potential for } \\
\text { Fire } \\
\end{array}$ & $\begin{array}{l}\text { Current } \\
\text { Invasive } \\
\text { Species, } \\
\text { Insects, and } \\
\text { Disease } \\
\text { Density } \\
\end{array}$ & $\begin{array}{l}\text { Future } \\
\text { Potential } \\
\text { Invasive } \\
\text { Species, } \\
\text { Insects, and } \\
\text { Disease } \\
\end{array}$ \\
\hline $\begin{array}{l}\text { Places of } \\
\text { Traditional }\end{array}$ & $\underline{\text { Low }}$ & $\underline{\text { Low }}$ & Very Low & Very Low & Moderate & Very Low & Very Low & $\underline{\text { Low }}$ & $\underline{\text { Very Low }}$ & Very High \\
\hline $\begin{array}{l}\text { Cultural } \\
\text { Importance to } \\
\text { Tribes }\end{array}$ & $\begin{array}{l}\text { Very Low: } \\
\text { 10.6\% } \\
\text { Low: 30.3\% } \\
\text { Mod Low: } \\
\text { 19.1\% } \\
\text { Mod High: } \\
\text { 12.6\% } \\
\text { High: 8.9\% } \\
\text { Very High: } \\
\text { 18.4\% }\end{array}$ & $\begin{array}{l}\text { Very Low: } \\
\text { 14.4\% } \\
\text { Low: 31.7\% } \\
\text { Mod Low: } \\
\text { 16.5\% } \\
\text { Mod High: } \\
\text { 11.3\% } \\
\text { High: 8.1\% } \\
\text { Very High: } \\
\text { 18.0\% }\end{array}$ & $\begin{array}{l}\text { Very Low: } \\
30.9 \% \\
\text { Low: } 30.6 \% \\
\text { Mod: } 15.3 \% \\
\text { High: } 12.5 \% \\
\text { Very High: } \\
\text { 10.7\% }\end{array}$ & $\begin{array}{l}\text { Very Low: } \\
29.1 \% \\
\text { Low: } 27.6 \% \\
\text { Mod: } 15.7 \% \\
\text { High: } 13.9 \% \\
\text { Very High: } \\
\text { 13.8\% }\end{array}$ & $\begin{array}{l}\text { Very Low: } \\
\text { 9.5\% } \\
\text { Low: } 30.1 \% \\
\text { Mod: } 36.6 \% \\
\text { High: } 16.3 \% \\
\text { Very High: } \\
\text { 7.5\% }\end{array}$ & $\begin{array}{l}\text { Very Low: } \\
40.4 \% \\
\text { Low: } 16.0 \% \\
\text { Mod: } 24.7 \% \\
\text { High: } 11.3 \% \\
\text { Very High: } \\
7.6 \%\end{array}$ & $\begin{array}{l}\text { Very Low: } \\
85.6 \% \\
\text { Low: } 7.8 \% \\
\text { Mod: } 1.8 \% \\
\text { High: } 1.4 \% \\
\text { Very High: } \\
3.4 \%\end{array}$ & $\begin{array}{l}\text { Very Low: } \\
11.6 \% \\
\text { Low: } 49.5 \% \\
\text { Mod: } 24.4 \% \\
\text { High: } 6.4 \% \\
\text { Very High: } \\
8.1 \%\end{array}$ & $\begin{array}{l}\text { Very Low: } \\
43.9 \% \\
\text { Mod Low: } \\
16.8 \% \\
\text { Mod high: } \\
16.0 \% \\
\text { Very High: } \\
23.3 \%\end{array}$ & $\begin{array}{l}\text { Very Low: } \\
\text { 18.8\% } \\
\text { Mod Low: } \\
21.6 \% \\
\text { Mod high: } \\
23.7 \% \\
\text { Very High: } \\
35.9 \%\end{array}$ \\
\hline
\end{tabular}

5 Conservation Element current and potential future conditions were based on the intersections between Conservation Element distributions and Change Agent models in the study area. Overall categorical determinations (in bold) are based on averages of modeled values. Percentages represent the relative proportion of each category. 


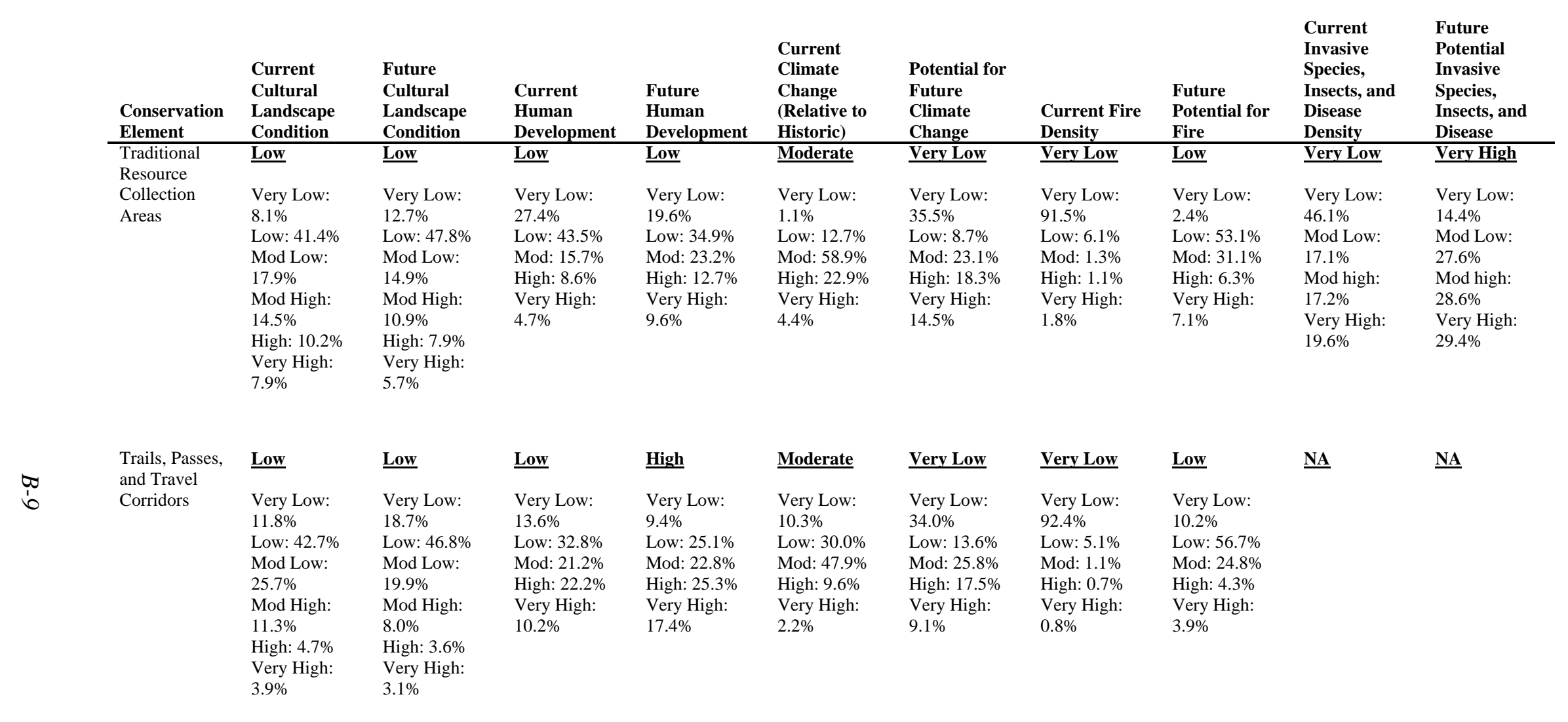




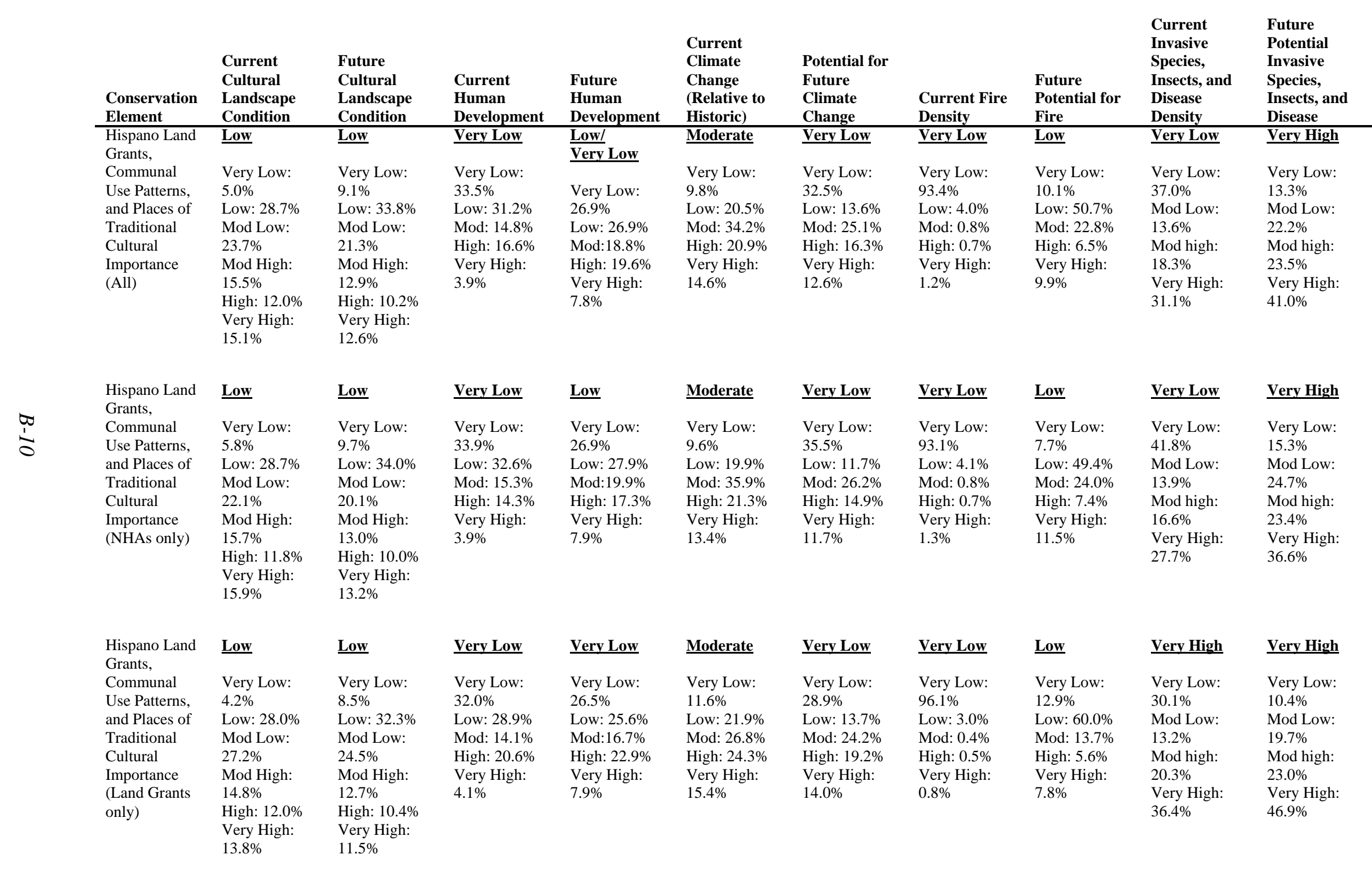




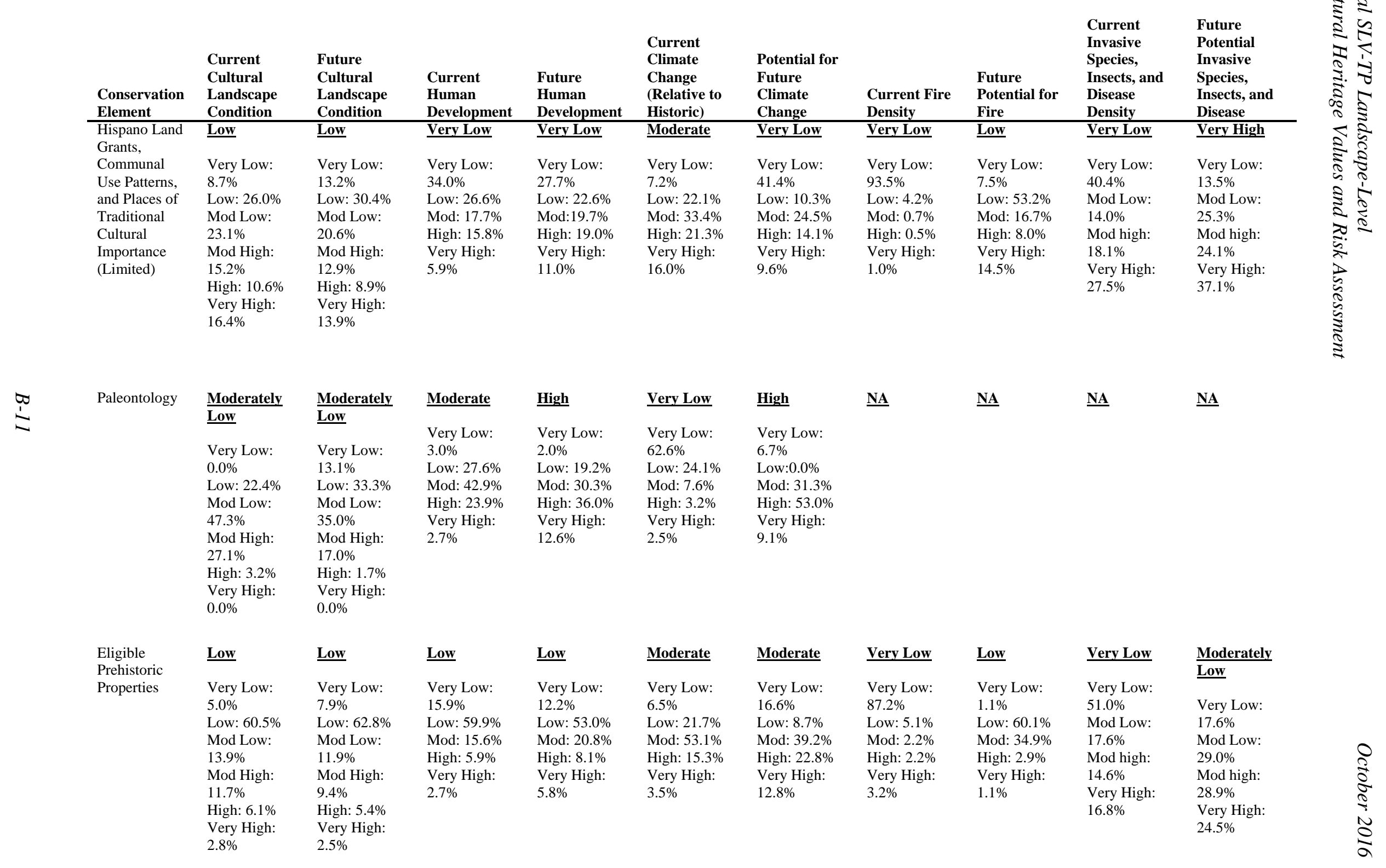




\begin{tabular}{|c|c|c|c|c|c|c|c|c|c|c|}
\hline $\begin{array}{l}\text { Conservation } \\
\text { Element }\end{array}$ & $\begin{array}{l}\text { Current } \\
\text { Cultural } \\
\text { Landscape } \\
\text { Condition } \\
\end{array}$ & $\begin{array}{l}\text { Future } \\
\text { Cultural } \\
\text { Landscape } \\
\text { Condition } \\
\end{array}$ & $\begin{array}{l}\text { Current } \\
\text { Human } \\
\text { Development }\end{array}$ & $\begin{array}{l}\text { Future } \\
\text { Human } \\
\text { Development }\end{array}$ & $\begin{array}{l}\text { Current } \\
\text { Climate } \\
\text { Change } \\
\text { (Relative to } \\
\text { Historic) } \\
\end{array}$ & $\begin{array}{l}\text { Potential for } \\
\text { Future } \\
\text { Climate } \\
\text { Change } \\
\end{array}$ & $\begin{array}{l}\text { Current Fire } \\
\text { Density }\end{array}$ & $\begin{array}{l}\text { Future } \\
\text { Potential for } \\
\text { Fire } \\
\end{array}$ & $\begin{array}{l}\text { Current } \\
\text { Invasive } \\
\text { Species, } \\
\text { Insects, and } \\
\text { Disease } \\
\text { Density } \\
\end{array}$ & $\begin{array}{l}\text { Future } \\
\text { Potential } \\
\text { Invasive } \\
\text { Species, } \\
\text { Insects, and } \\
\text { Disease } \\
\end{array}$ \\
\hline $\begin{array}{l}\text { Eligible } \\
\text { Historic }\end{array}$ & $\underline{\text { Low }}$ & $\underline{\text { Low }}$ & $\underline{\text { Low }}$ & $\underline{\text { Low }}$ & Moderate & Moderate & Very Low & $\underline{\text { Low }}$ & Very Low & Very High \\
\hline Properties & $\begin{array}{l}\text { Very Low: } \\
4.9 \% \\
\text { Low: 63.4\% } \\
\text { Mod Low: } \\
\text { 17.0\% } \\
\text { Mod High: } \\
7.8 \% \\
\text { High: 4.5\% } \\
\text { Very High: } \\
\text { 2.4\% }\end{array}$ & $\begin{array}{l}\text { Very Low: } \\
\text { 9.2\% } \\
\text { Low: 65.3\% } \\
\text { Mod Low: } \\
\text { 14.0\% } \\
\text { Mod High: } \\
\text { 6.2\% } \\
\text { High: 3.5\% } \\
\text { Very High: } \\
\text { 1.7\% }\end{array}$ & $\begin{array}{l}\text { Very Low: } \\
\text { 12.6\% } \\
\text { Low: } 53.3 \% \\
\text { Mod: } 15.0 \% \\
\text { High: } 13.7 \% \\
\text { Very High: } \\
\text { 5.4\% }\end{array}$ & $\begin{array}{l}\text { Very Low: } \\
9.2 \% \\
\text { Low: } 47.6 \% \\
\text { Mod: } 18.8 \% \\
\text { High: } 15.4 \% \\
\text { Very High: } \\
9.0 \%\end{array}$ & $\begin{array}{l}\text { Very Low: } \\
6.7 \% \\
\text { Low: } 25.6 \% \\
\text { Mod: } 52.8 \% \\
\text { High: } 9.8 \% \\
\text { Very High: } \\
\text { 5.1\% }\end{array}$ & $\begin{array}{l}\text { Very Low: } \\
\text { 19.1\% } \\
\text { Low: 8.3\% } \\
\text { Mod: 39.9\% } \\
\text { High: 22.8\% } \\
\text { Very High: } \\
\text { 9.9\% }\end{array}$ & $\begin{array}{l}\text { Very Low: } \\
88.2 \% \\
\text { Low: } 4.8 \% \\
\text { Mod: } 2.0 \% \\
\text { High: } 1.9 \% \\
\text { Very High: } \\
3.1 \%\end{array}$ & $\begin{array}{l}\text { Very Low: } \\
6.8 \% \\
\text { Low: } 53.4 \% \\
\text { Mod: } 34.7 \% \\
\text { High: } 3.2 \% \\
\text { Very High: } \\
1.9 \%\end{array}$ & $\begin{array}{l}\text { Very Low: } \\
47.1 \% \\
\text { Mod Low: } \\
14.5 \% \\
\text { Mod high: } \\
15.2 \% \\
\text { Very High: } \\
23.2 \%\end{array}$ & $\begin{array}{l}\text { Very Low: } \\
\text { 18.0\% } \\
\text { Mod Low: } \\
25.9 \% \\
\text { Mod high: } \\
24.7 \% \\
\text { Very High: } \\
31.4 \%\end{array}$ \\
\hline
\end{tabular}




\section{B.1 Places of Traditional Cultural Importance to Tribes}

Many Native American tribes have spiritual, emotional, ancestral, and contemporary ties to the San Luis Valley - Taos Plateau. Within the study area are culturally important natural resources and significant cultural landscapes that serve as the settings for tribal histories and traditional narratives. Contemporary ways of life are rooted in traditions influenced by these sacred spaces and past experiences. These places are integral to Native American practices and beliefs and are important for maintaining a community's cultural identity. (It is important to note that these places have not been formally designated as traditional cultural properties that are listed on the National Register of Historic Places, but this assessment recognizes them as places of traditional importance that could receive formal status at some other point in the future.) Data specific to the Ute, Jicarilla Apache, Navajo, Pueblo, and Plains Tribes are not depicted individually in this document, but are available to the BLM in the GIS data accompanying this assessment.

Places of traditional cultural importance were identified through a review of ethnographic literature (Higgins et al. 2013; Stoffle et al. 2008; White 2005), as well as knowledge from those who have worked with tribes in the area. The data include mountain peaks, volcanic domes, river crossings, geological formations, Pueblos, battle sites, lakes and wetland areas, springs, canyons, archaeological sites, trails, and shrines and are discussed throughout Section 2 of this document. This is a first cut at these important places based on existing literature and agency knowledge, and future updates to these data are recommended to be completed in formal consultation with the tribes.

Figure B.1-1 shows the spatial distribution of places of traditional cultural importance to tribes, and Figure B.1-2 illustrates current and future cultural landscape condition for these places based on the modeling described in Section 4.2.2. Figures B.1-3 and B.1-4 provide the distribution of these places of cultural importance intersected with each of the change agents separately at current and future conditions, respectively. The change agent models are identical to those used for the Landscape Assessment and details on their derivations are described in full in that document (Walston et al. 2016). The bar graphs in Figure B.1-5 (based on data presented in Table B-2) are intended to show the trends from current condition to future condition based on percentage of area affected. The areas in this conservation element show trends of small increases (less than 5\%) in human development and larger increases in wildfire potential (10\% for high and very high) and invasive species, insects, and disease (nearly $20 \%$ for very high and moderate high) for the near-term future (i.e., by 2030). The areas in this conservation element show reduced levels of climate change effects (i.e., reductions in the fluctuation of temperature and precipitation) generally in low, moderate, and high potential categories in the future (i.e., by 2060), except for a slight increase $(0.1 \%)$ in the very high potential category. Changes in landscape condition are small with reductions in high condition areas of less than $1 \%$. 


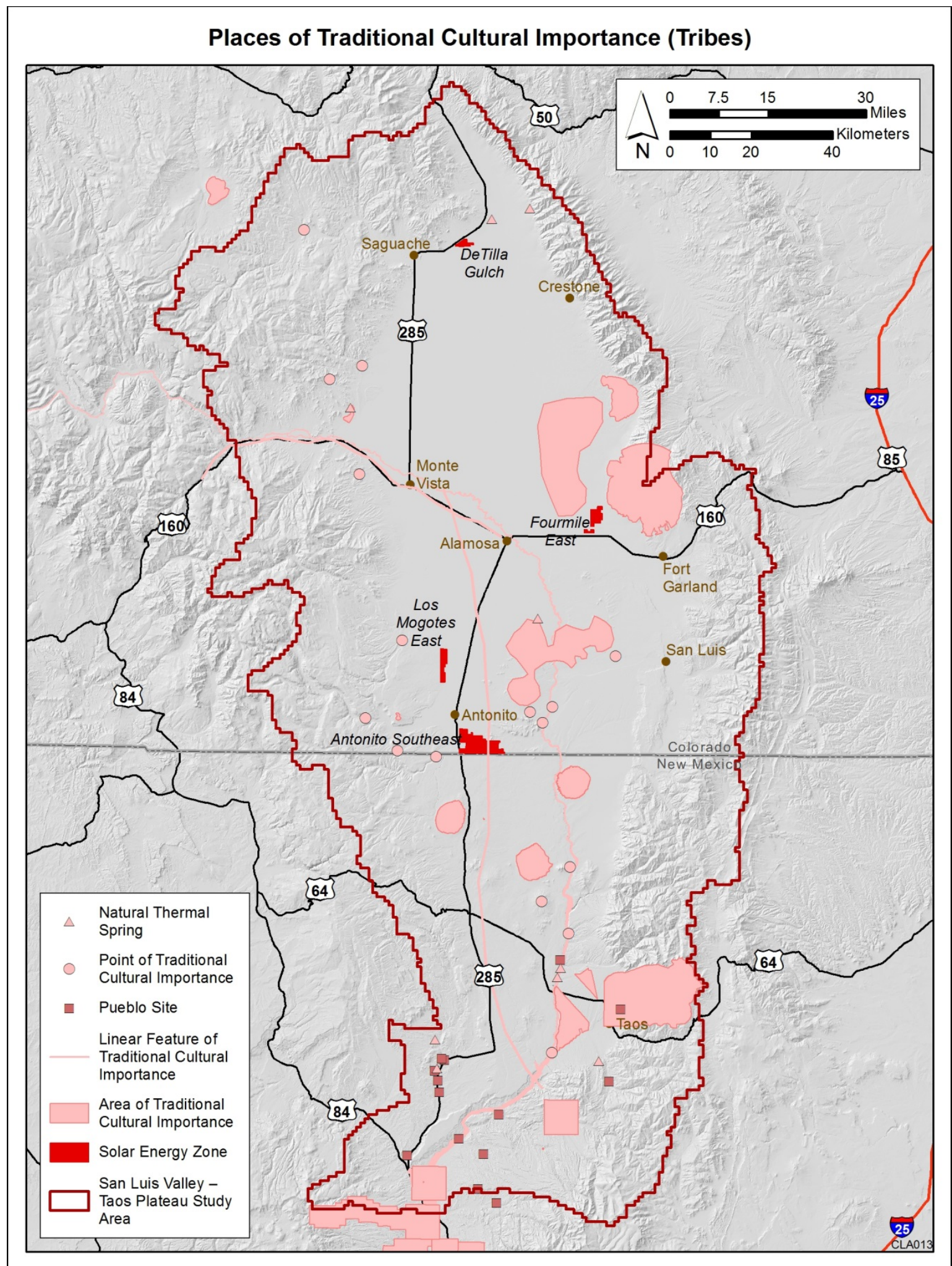

Figure B.1-1. Current Distribution of Places of Traditional Cultural Importance to Tribes 


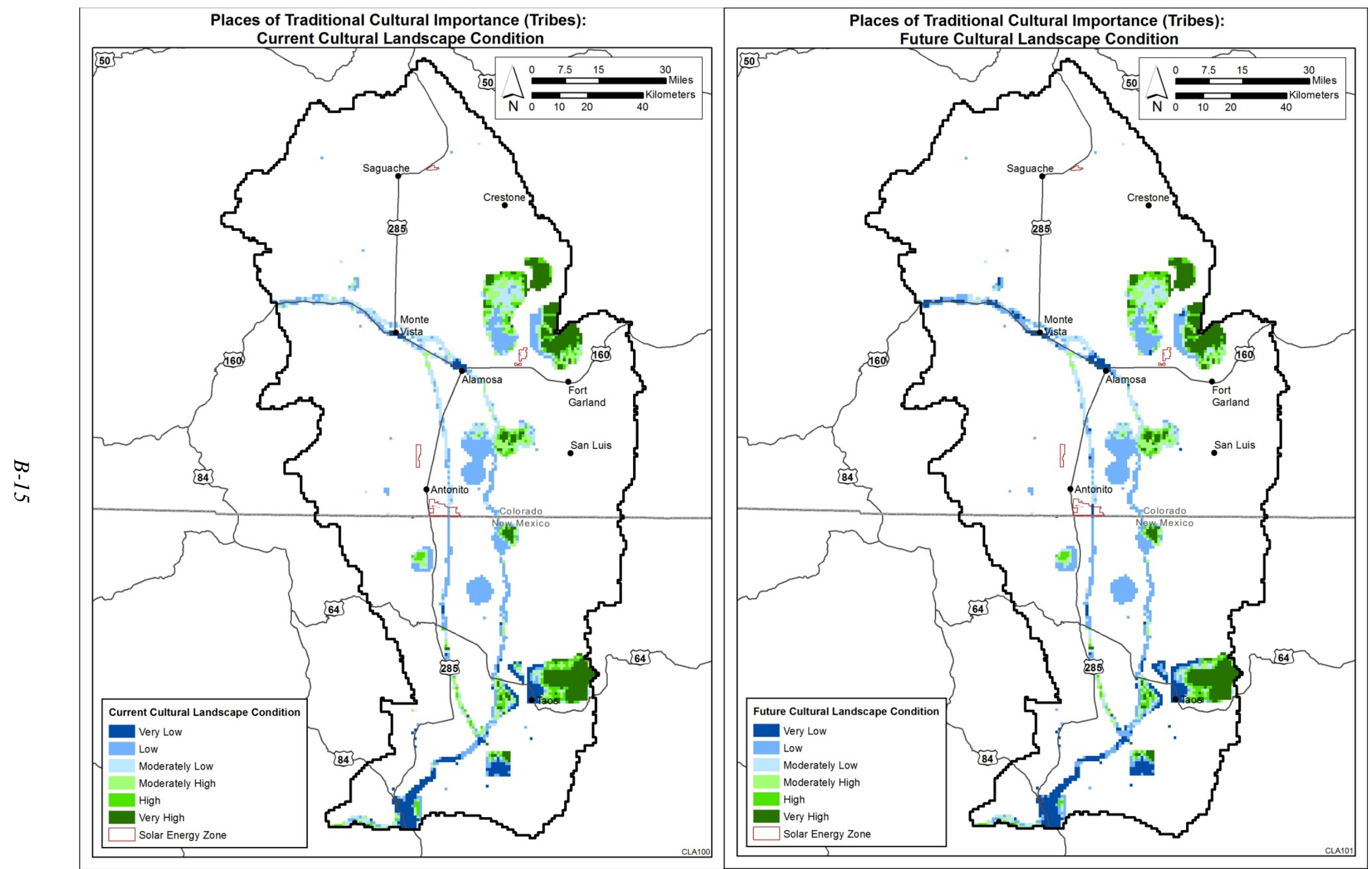

Figure B.1-2. Current and Future Landscape Condition of Places of Traditional Cultural Importance to Tribes 

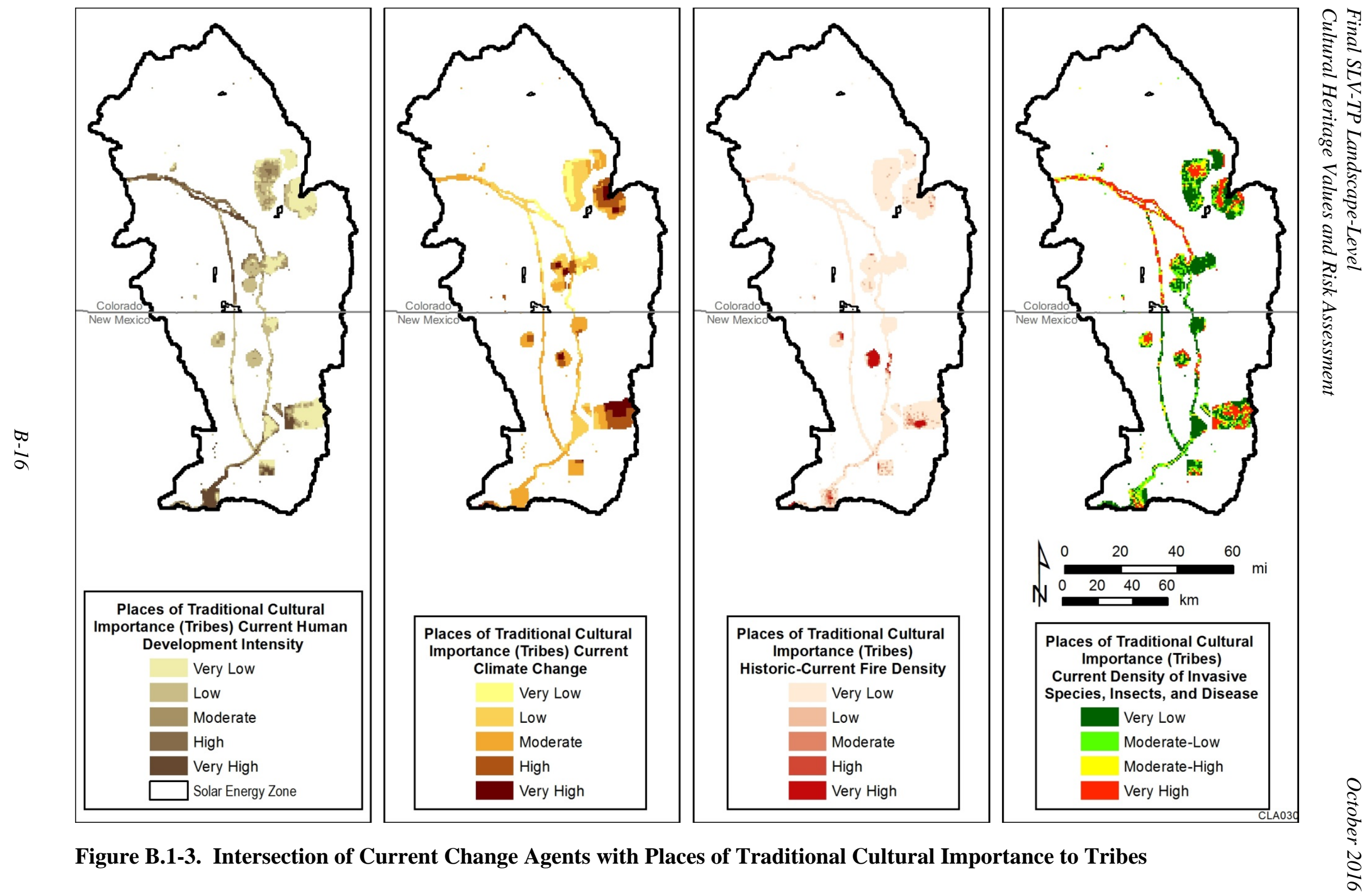

Figure B.1-3. Intersection of Current Change Agents with Places of Traditional Cultural Importance to Tribes 

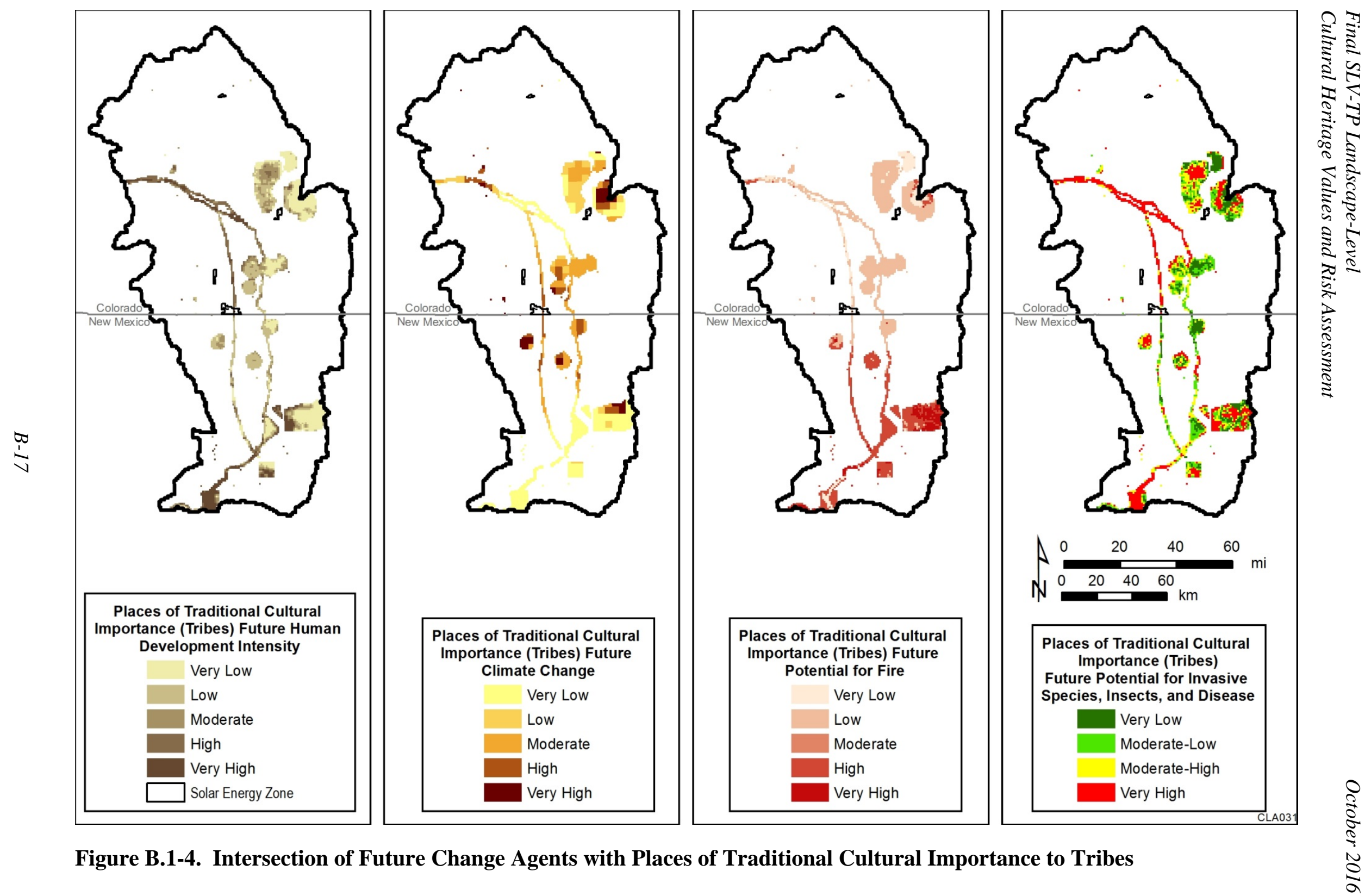

Figure B.1-4. Intersection of Future Change Agents with Places of Traditional Cultural Importance to Tribes 

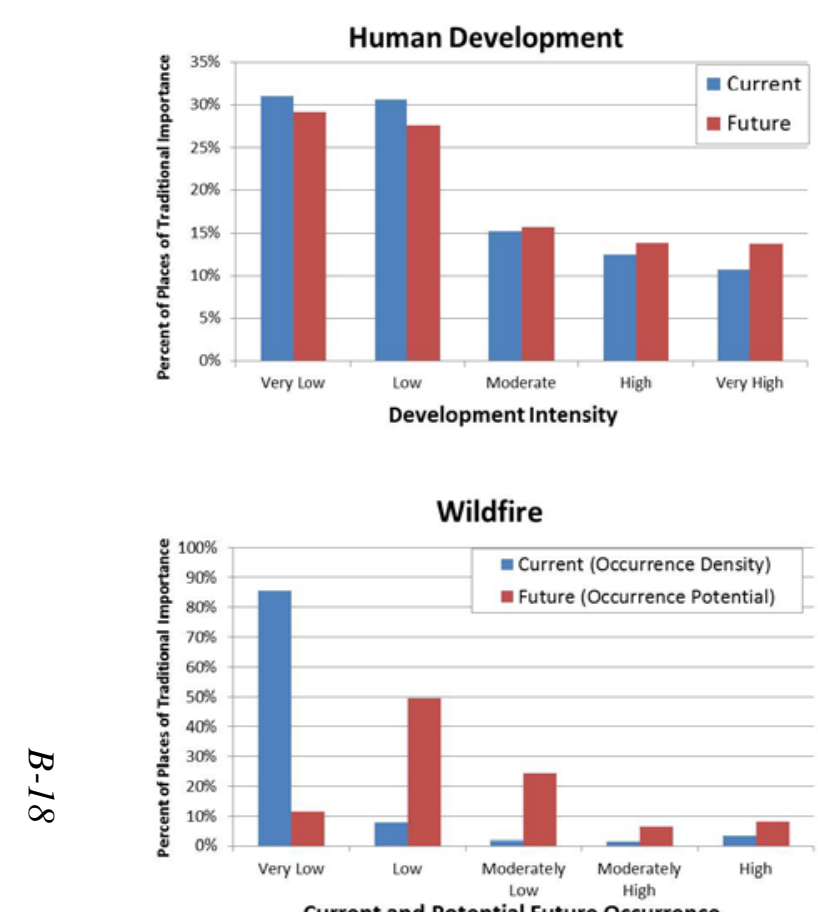

Current and Potential Future Occurrence

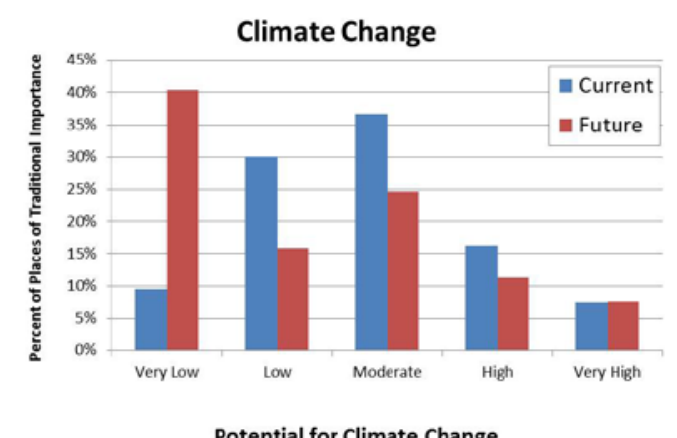

Potential for Climate Change

Invasive Species, Insects, and Disease

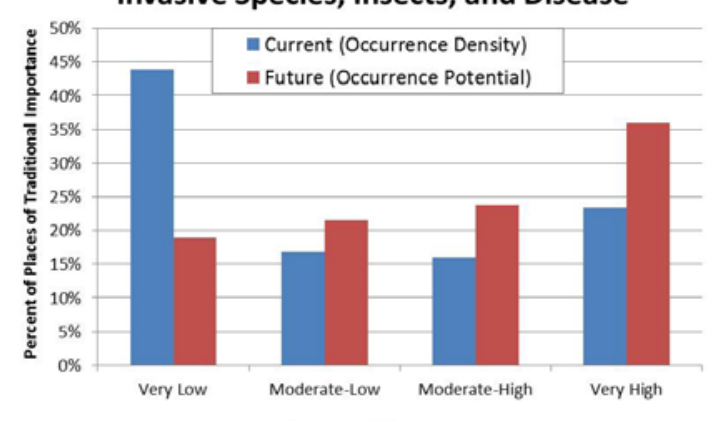

Current and Potential Future Occurrence

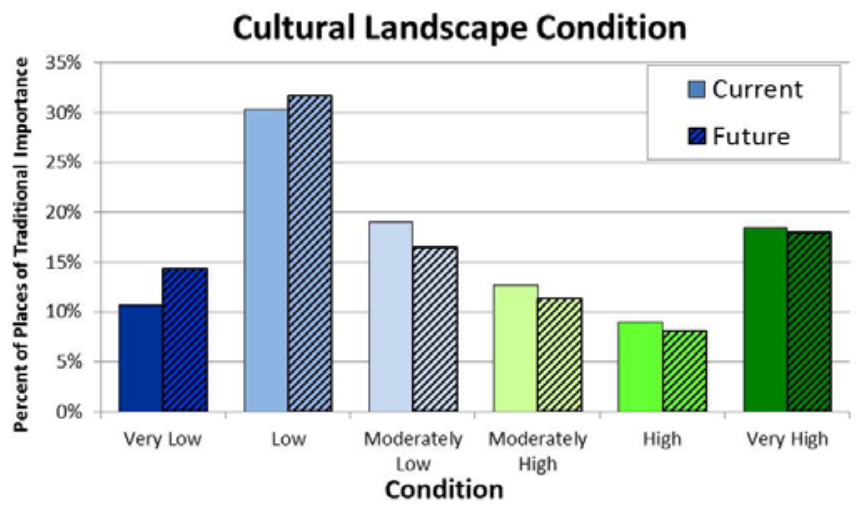

Figure B.1-5. Predicted Trends in Places of Traditional Cultural Importance to Tribes within the Study Area 


\section{B.2 Traditional Resource Collection Areas}

The valley is home to many plants, animals, and minerals historically and contemporarily used and valued by Native American, Hispano, and other local communities. Representatives of the Jicarilla, Navajo, Ute, Picuris, and Hispano communities have all identified specific locations within the valley that contain plants, animals, or minerals that have been or are currently used as raw material for cultural items as well as food, fuel, and medicinal and ceremonial purposes.

Traditional Resource Collection Areas were identified through a review of ethnographic literature (Higgins et al. 2013; Stoffle et al. 2008; White 2005) and SHPO data, as well as information based on local expert knowledge. Places identified under the Traditional Resource Collection Areas Cultural Conservation Element include oshá collection areas, wetlands, culturally-modified tree clusters, pinyon-juniper woodlands, La Botica, the Punche Valley, and micaceous clay sources and are discussed throughout Section 2 of this document.

Figure B.2-1 shows the spatial distribution of the traditional resource collection areas, and Figure B.2-2 illustrates current and future cultural landscape condition for the resource collection areas based on the modeling described in Section 4.2.2. Figures B.2-3 and B.2-4 provide the full distribution of traditional resource collection areas intersected with each of the change agents separately at current and future conditions, respectively. The change agent models are identical to those used for the Landscape Assessment and details on their derivations are described in full in that document (Walston et al. 2016). The bar graphs in Figure B.2-5 (based on data presented in Table B-2) are intended to show the trends from current condition to future condition based on percentage of area affected. Invasive species, insects, and disease are anticipated to be a major impacting factor for traditional collection areas, and the available data show that increases of about $20 \%$ in high occurrence (moderate high and very high) potential are projected. Much of the area most heavily affected by this change agent is also affected by very high projected changes in precipitation and temperature. Although the data show predominantly (nearly 60\% of the area) moderate levels of change in precipitation and temperature from historic times to present throughout the areas identified by this conservation element, an increase in areas of very high changes in precipitation and temperature of nearly $10 \%$ is projected. Interestingly, areas of very low potential for experiencing climate change effects also increases over $30 \%$ in the future (i.e., by 2060), particularly in the southern part of the study area, and the areas of expected moderate change decrease to $23 \%$. Wildfire occurrence potential increases in the near future (by 2030) for all categories other than where very low occurrence density has been recorded, but most projected areas are identified as low or moderately low potential. About 13\% of the area has a projected wildfire occurrence potential of moderately high or high, up from a current occurrence density of 3\%; that potential area is also located in the southern part of the study area. Human development and cultural landscape condition go together with steady reduction in condition across all categories (ranging from 2 to 6\%) with a 5 to $7 \%$ increase in development intensity. 


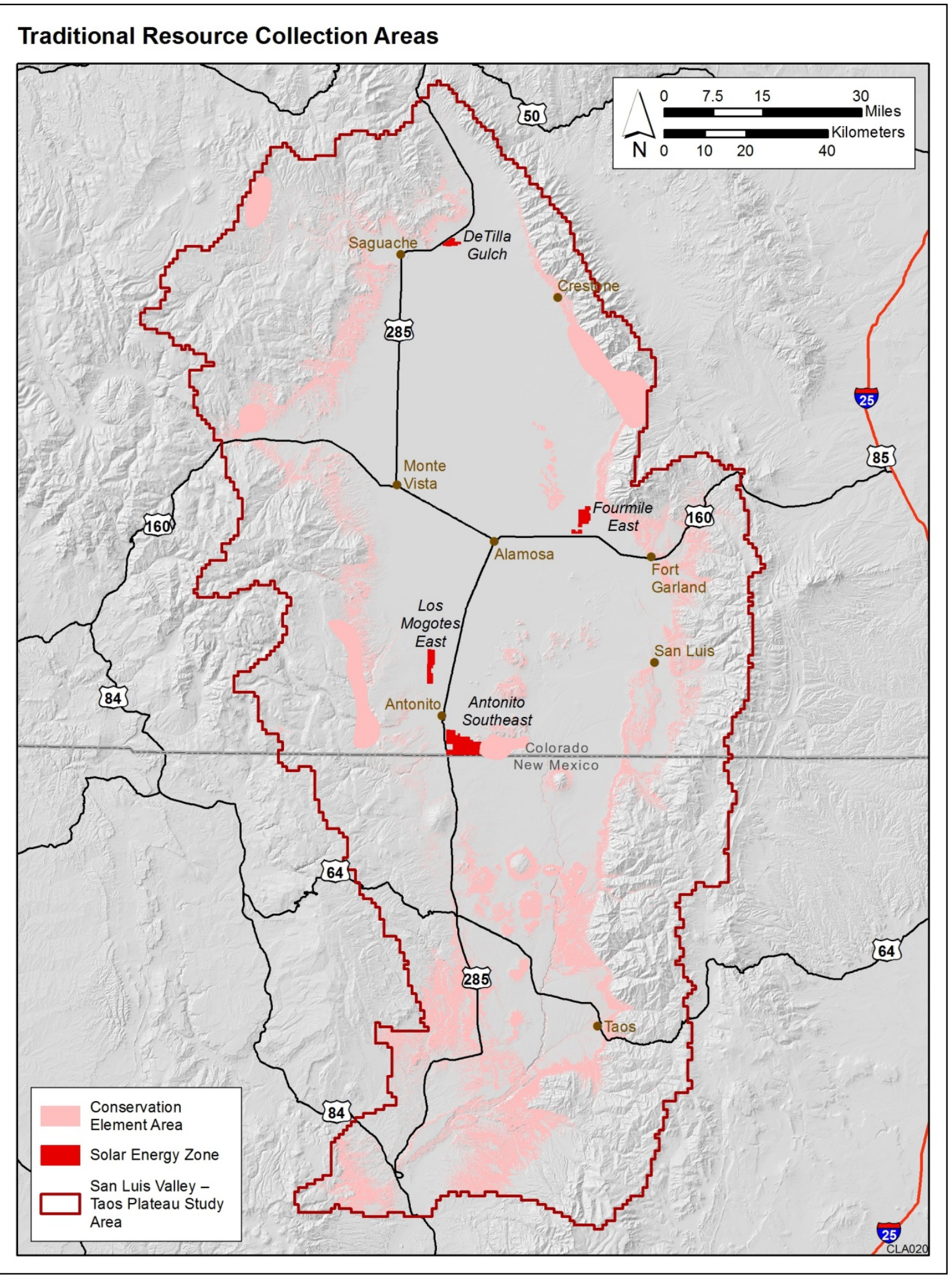

Figure B.2-1. Current Distribution of Places of Traditional Resource Collection Areas 


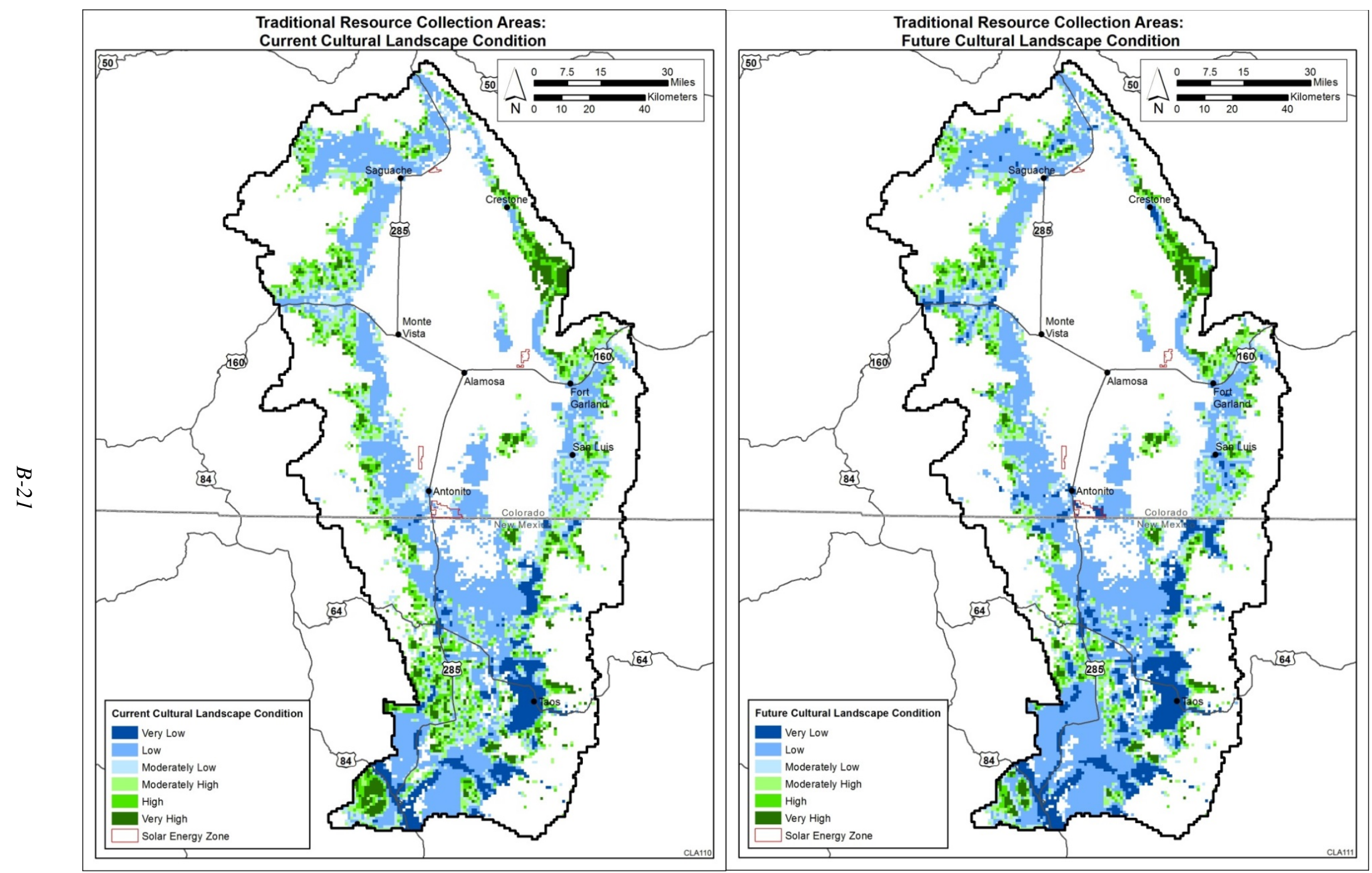

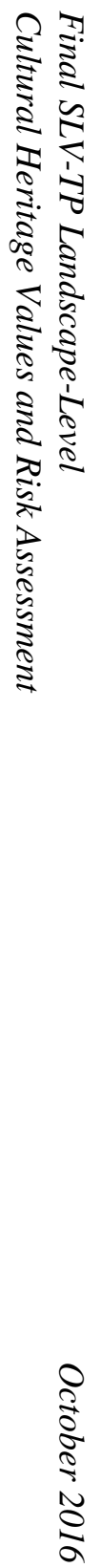

Figure B.2-2. Current and Future Landscape Condition of Traditional Resource Collection Areas 

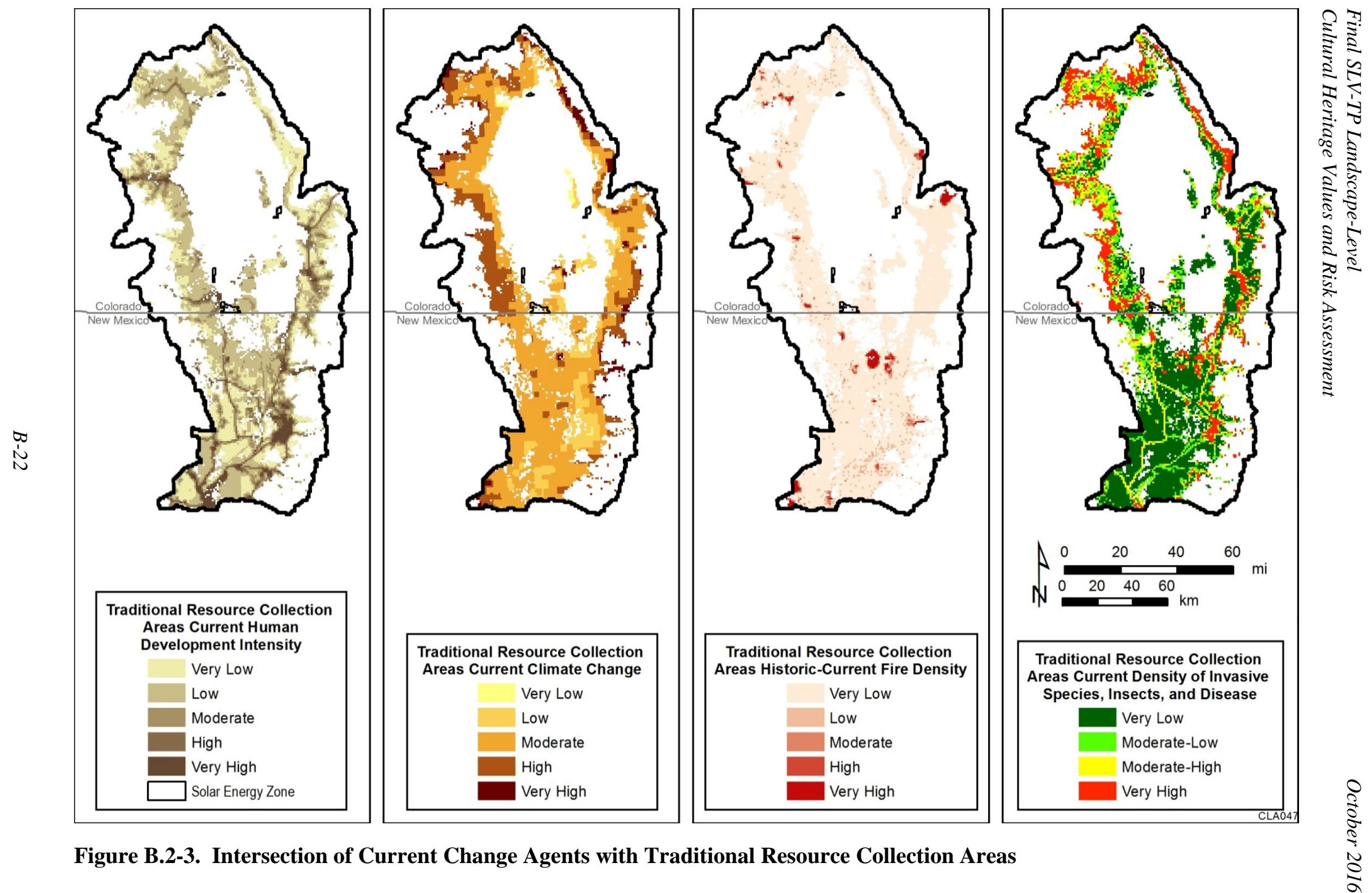

Figure B.2-3. Intersection of Current Change Agents with Traditional Resource Collection Areas 

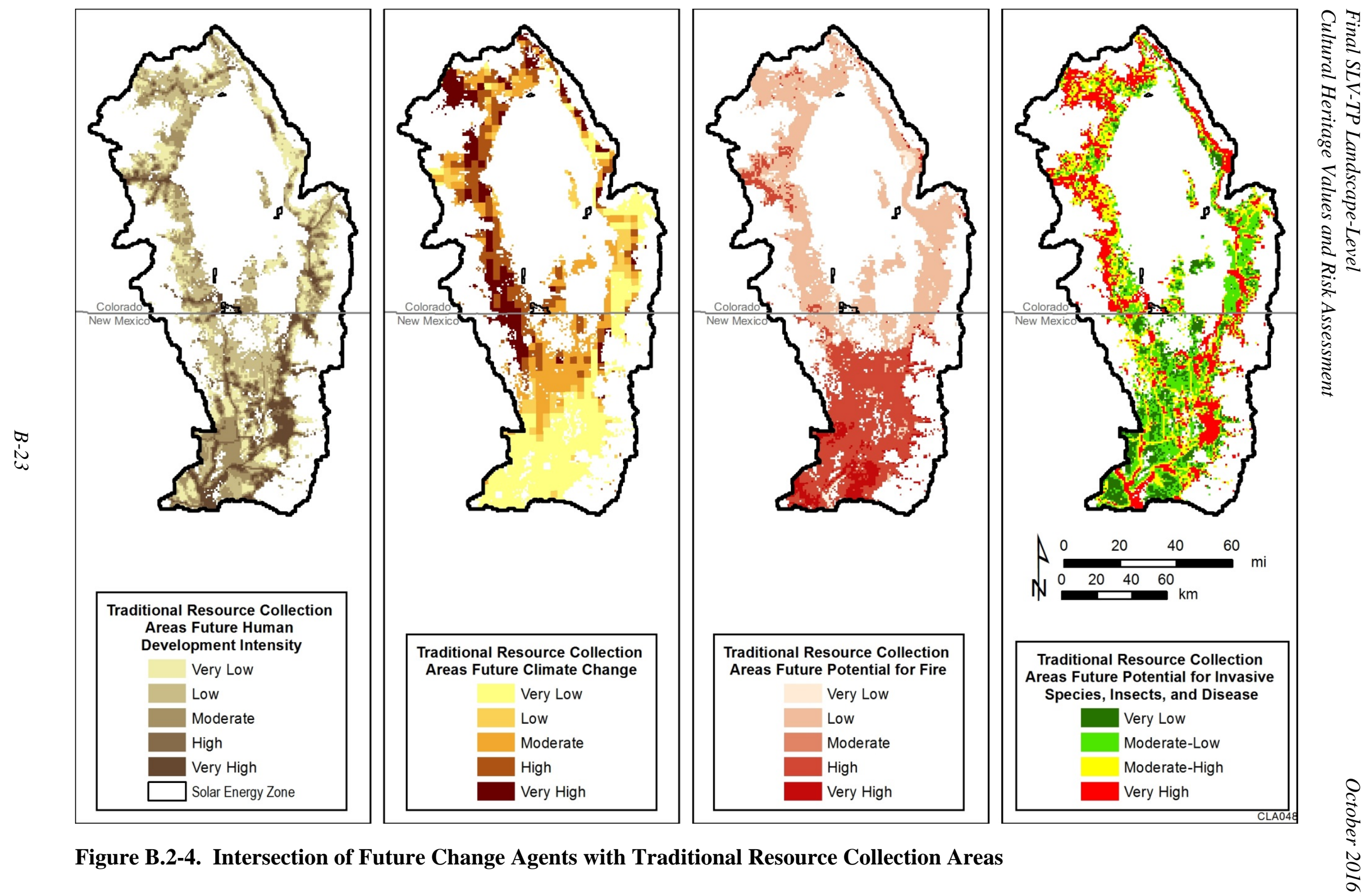

Figure B.2-4. Intersection of Future Change Agents with Traditional Resource Collection Areas 

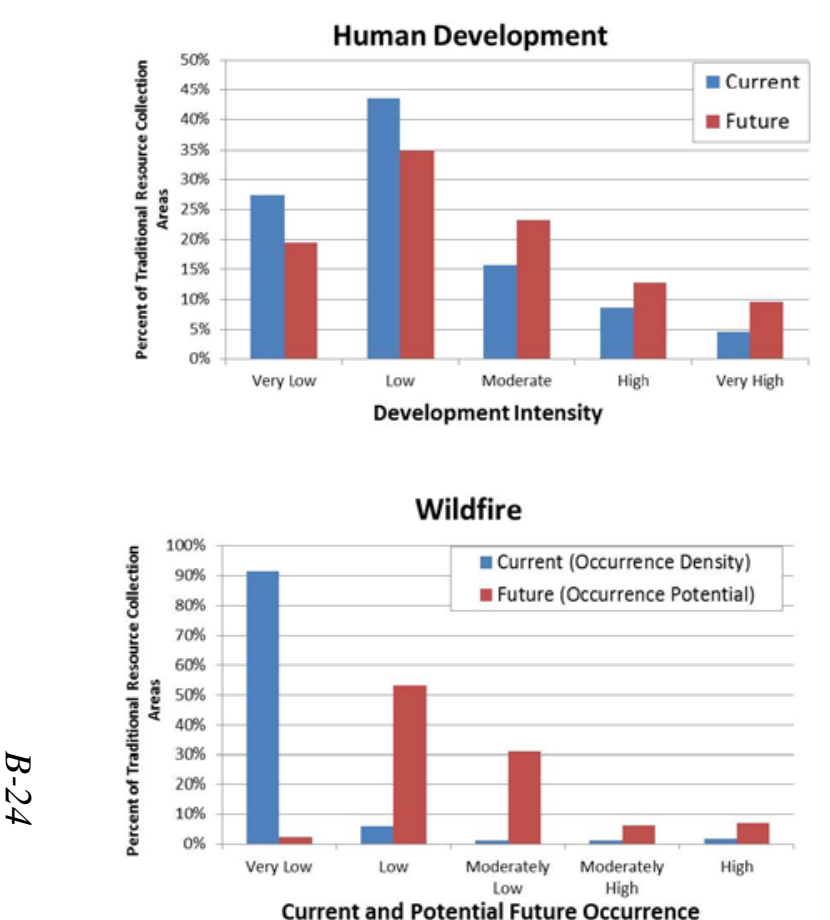

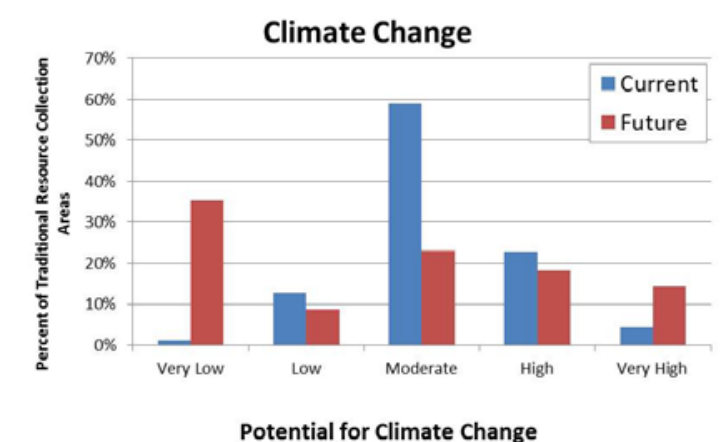

Potential for Climate Change

Invasive Species, Insects, and Disease

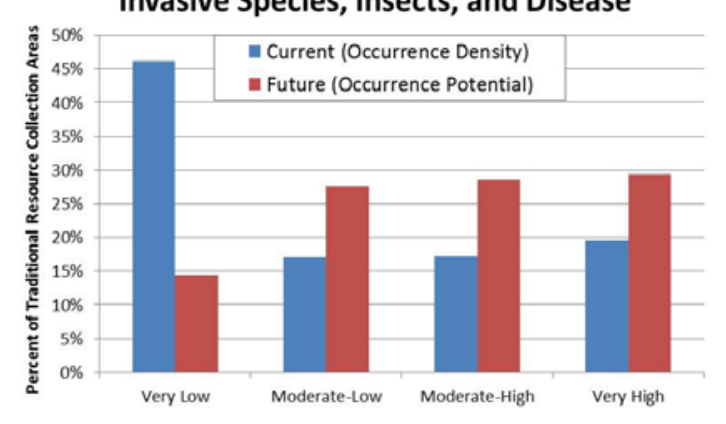

Current and Potential Future Occurrence

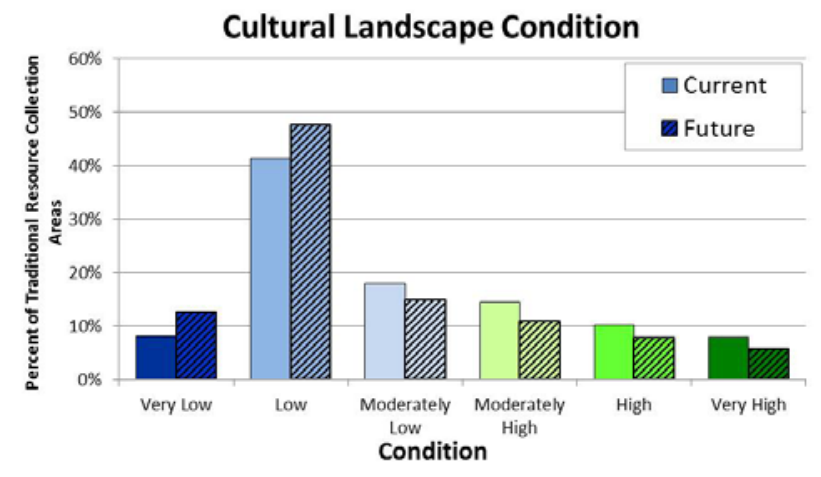

Figure B.2-5. Predicted Trends in Traditional Resource Collection Areas within the Study Area 


\section{B.3 Trails, Passes, and Travel Corridors}

Trails, mountain passes, and travel corridors all have unique rolls in the settlement of the San Luis Valley and in the connectivity of important places. Prehistoric and historic travel and trade routes connected settlements and allowed individuals access to important resources while mountain passes provided access in an out of the region. Today, many of those trails and travel corridors used by Native Americans; Spanish, Mexican, and American Explorers; fur-traders; and emigrants are still in use as major thoroughfares and serve as important tourist destinations in the form of historic trails and scenic byways. These places are discussed throughout Section 2.

Figure B.3-1 shows the spatial distribution of the trails, passes, and travel corridors identified in this assessment, and Figure B.3-2 illustrates current and future cultural landscape condition for these conservation elements based on the modeling described in Section 4.2.2. Figures B.3-3 and B.3-4 provide the distribution of the transportation routes intersected with each of the relevant change agents separately at current and future conditions, respectively. Invasive species, insects, and disease were not identified as a change agent that would affect this conservation element. The change agent models are identical to those used for the Landscape Assessment and details on their derivations are described in full in that document (Walston et al. 2016). The bar graphs in Figure B.3-5 (based on data presented in Table B-2) are intended to show the trends from current condition to future condition based on percentage of area affected. Although the data show predominantly low and moderate levels of change in precipitation and temperature from historic times to present throughout the areas identified by this conservation element, an increase to high and very high changes in precipitation and temperature of $15 \%$ of the area is projected. Interestingly, areas of very low potential for experiencing climate change effects also increases about $24 \%$ in the future (i.e., by 2060), particularly in the southern part of the study area. An increase in high and very high human development intensity of $10 \%$ is also noted, although the percent of the area developed in and around these travel corridors is generally quite evenly distributed. Wildfire occurrence potential increases in the future for all categories other than where very low occurrence density has been recorded, but most projected areas are identified as low or moderately low potential. Less than $10 \%$ of the area has a projected wildfire occurrence potential of moderately high or high, and again that potential appears to be focused in the southern part of the study area. Also depicted in Figure B.3-5 is a steady, but small (1\%) reduction in each of the high and very high levels of cultural landscape condition. 


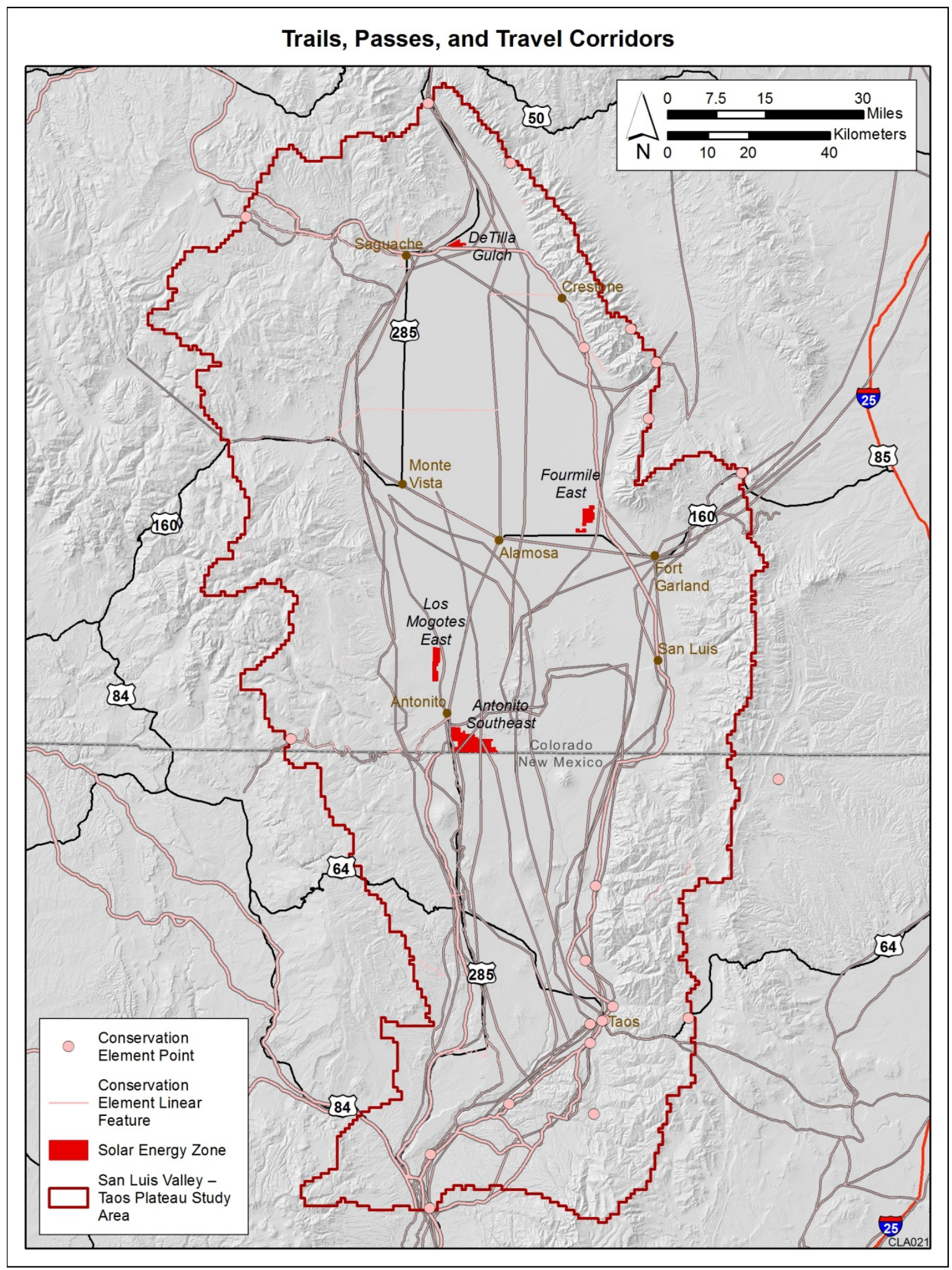

Figure B.3-1. Current Distribution of Trails, Passes, and Travel Corridors 


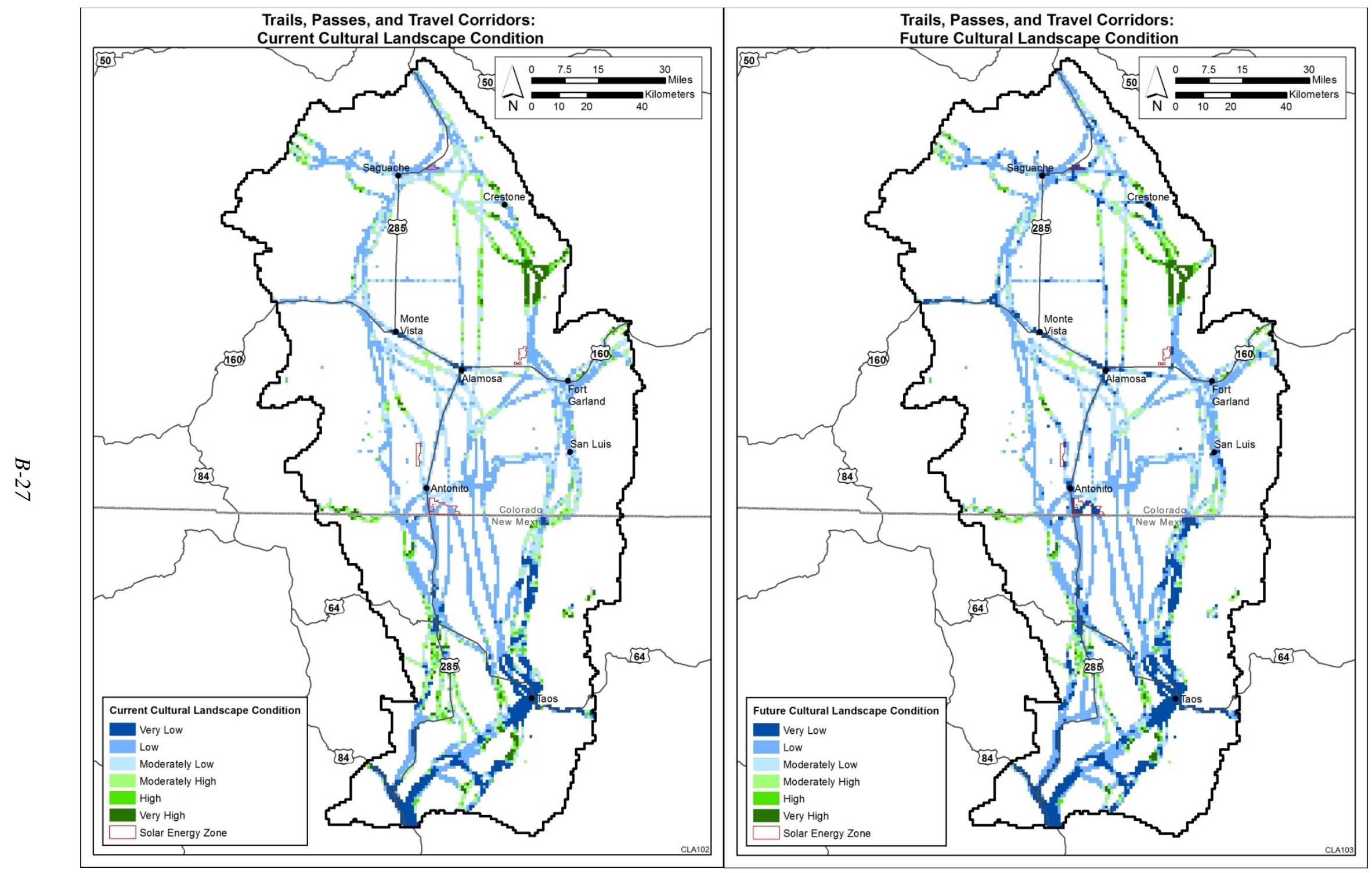

Figure B.3-2. Current and Future Landscape Condition of Trails, Passes, and Travel Corridors 

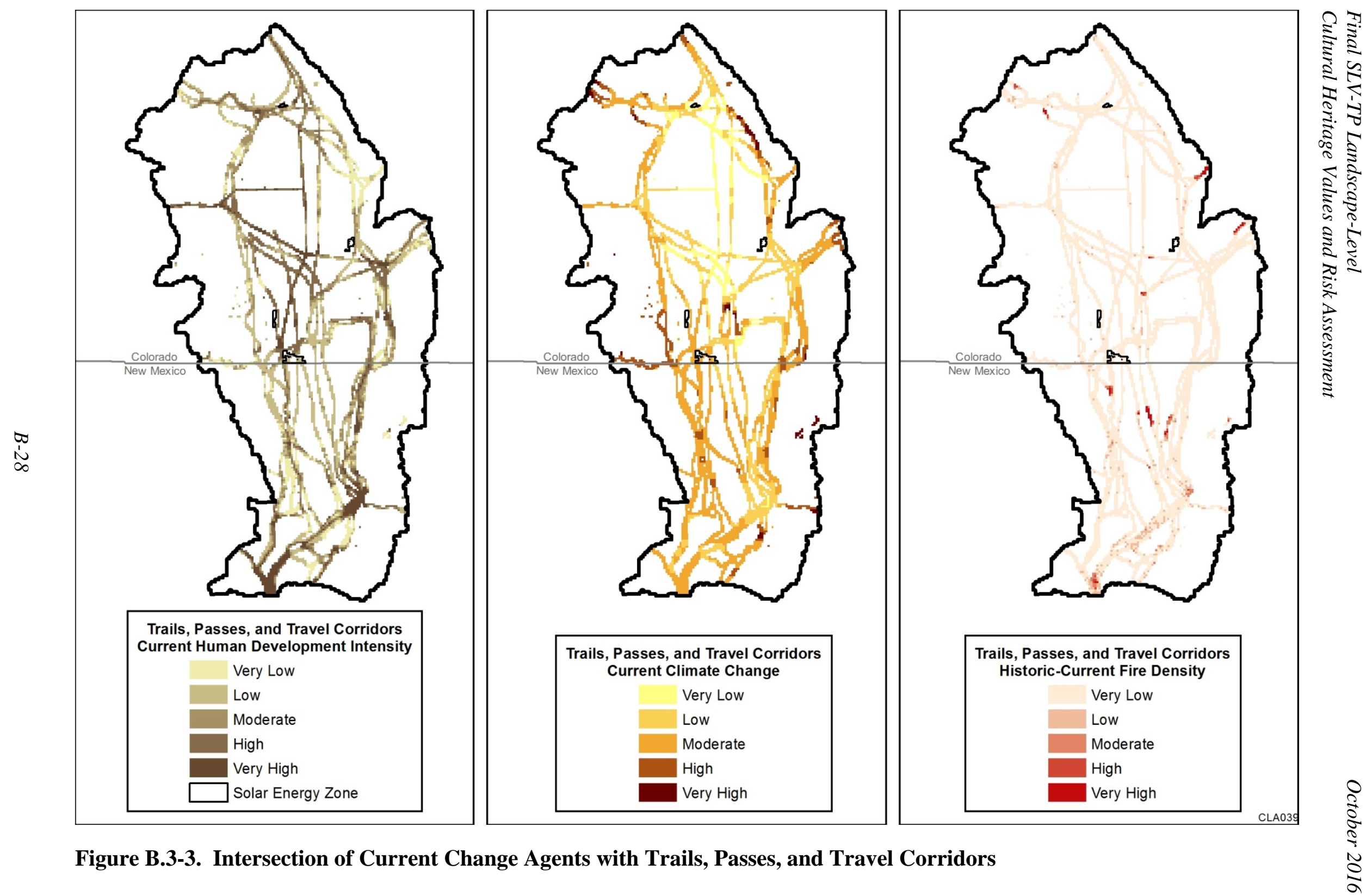

Figure B.3-3. Intersection of Current Change Agents with Trails, Passes, and Travel Corridors 

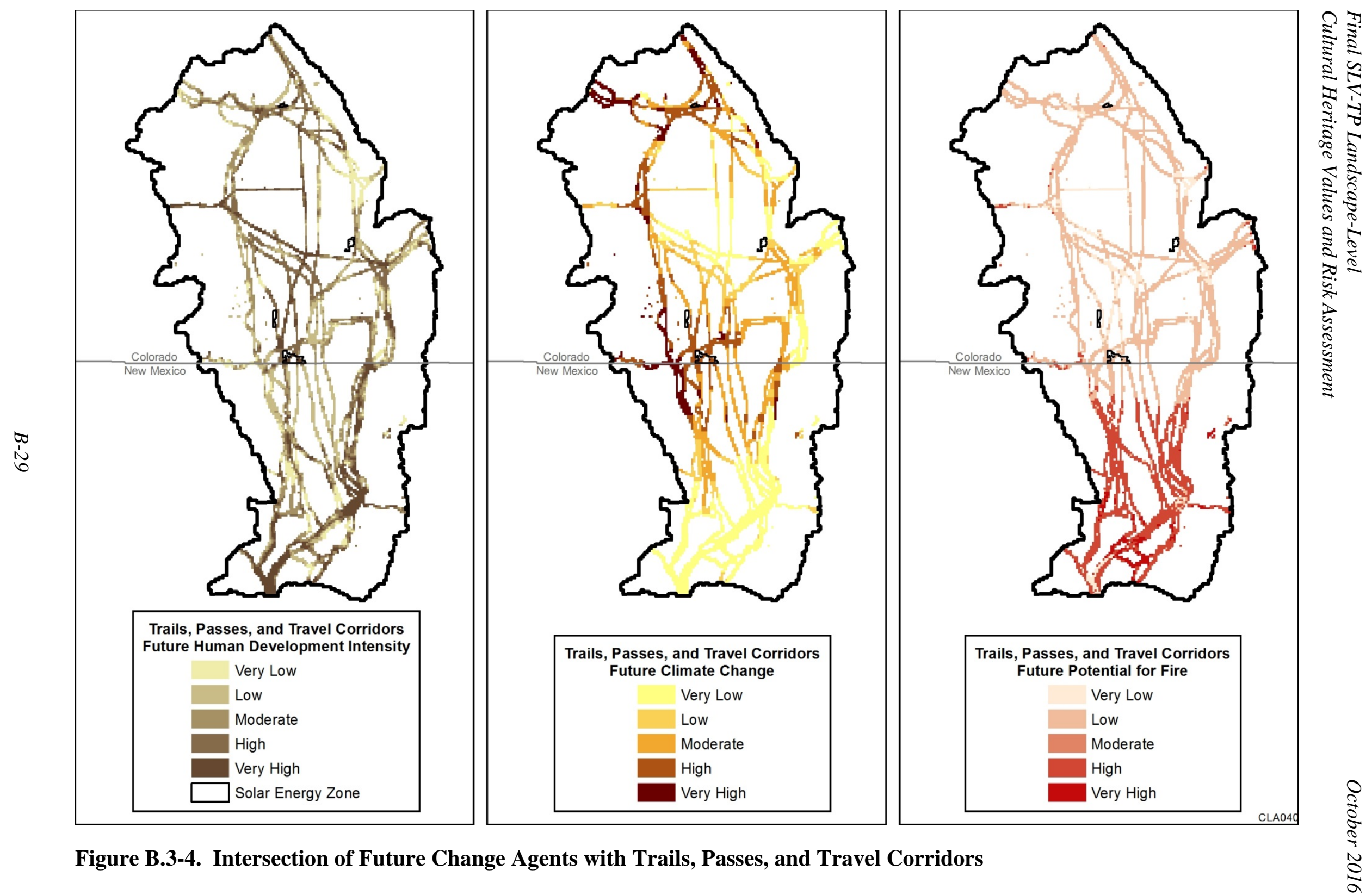

Figure B.3-4. Intersection of Future Change Agents with Trails, Passes, and Travel Corridors 

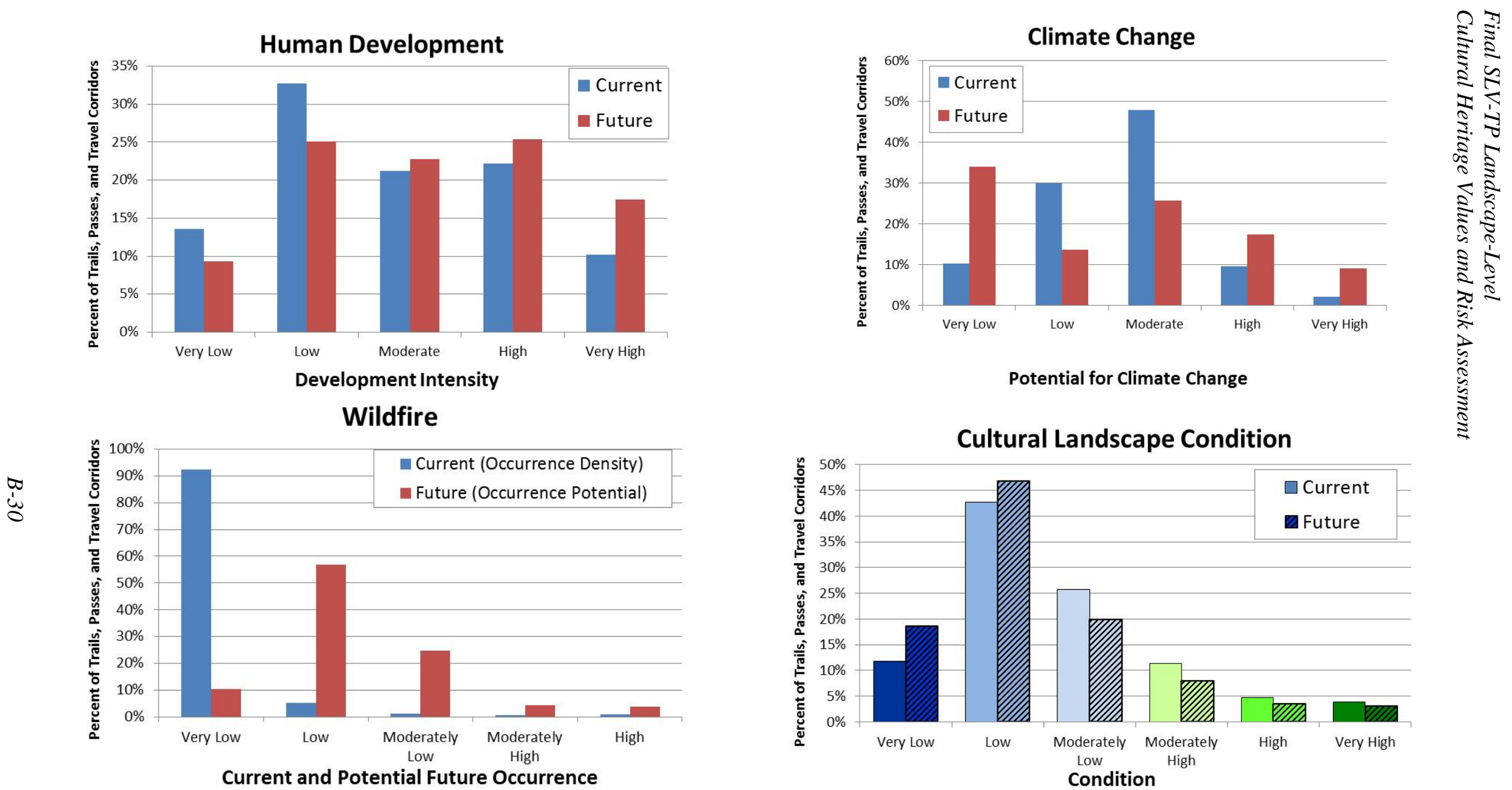

Figure B.3-5. Predicted Trends in Trails, Passes, and Travel Corridors within the Study Area 


\section{B.4 Hispano Land Grants, Communal Use Patterns, and Places of Traditional Cultural Importance}

The San Luis Valley - Taos Plateau is a living cultural landscape with a vibrant Hispano community whose cultural traditions are closely integrated with the landscape. Many Hispano residents are descendants of families who held title to original land grants issued from Spain and Mexico. Early settlements were founded on the concept of shared space and communal land use that promoted a strong land and water conservation ethic that considered a community's longterm survival. Although urbanization, contemporary farming practices, and urban development have affected traditional life ways and shifted communal use patterns, the Hispano Community continues to practice these communal concepts of shared resources and shared space. Long lot agriculture is still practiced throughout the valley. Land and water rights, as well as protection of the land, are very important issues to the Hispano community. Water is very important for both grazing and agriculture, and wild plants throughout the valley have been historically and contemporarily used for food, fuel, and medicinal purposes (Higgins et al. 2013; Stoffle et al. 2008).

Hispano Land Grants, Communal Use Patterns and Places of Traditional Cultural Importance were identified through a review of relevant literature including Higgins et al. 2013 and Stoffle et al. 2008, as well as the Center for Land Grant Studies website and local expert knowledge. Resources identified include land grant boundaries, historic homesteads, historic towns, plazas, acequia systems, sites associated with Spanish and Mexican history, and historic and contemporary communal collection areas. These places are important to Hispano cultural and religious practices and beliefs and are necessary for maintaining the community's cultural identity and are discussed throughout Section 2 of this document.

Figure B.4-1 shows the spatial distribution of Hispano land grants, communal use patterns, and places of traditional cultural importance, and Figures B.4-2 illustrates current and future cultural landscape condition for the full range of Hispano conservation elements based on the modeling described in Section 4.2.2. Figures B.4-3 and B.4-4 provide the distribution of the Hispano conservation elements intersected with each of the change agents separately at current and future conditions, respectively. The change agent models are identical to those used for the Landscape Assessment and details on their derivations are described in full in that document (Walston et al. 2016). Additional figures (B.4-6 through B.4-17) are shown for various aspects of the Hispano conservation elements, such as the National Heritage Areas (NHAs), the land grants, and more specific Hispano resources not including the larger land grant areas or NHAs. The bar graphs in Figure B.4-5 (based on data presented in Table B-2) are intended to show the trends from current condition to future condition based on percentage of area affected. The areas in this conservation element show trends of small increases (approximately $7 \%$ or less) in human development and larger increases in wildfire potential (15\% for high and very high combined) and invasive species, insects, and disease (about $15 \%$ for very high and moderate high) for the near-term future (i.e., by 2030). The areas in this conservation element also show reduced levels of climate change (i.e., reductions in fluctuations of temperature and precipitation) in the future (i.e., by 2060). Changes in landscape condition are small with reductions in high and very high condition areas of less than $3 \%$ each. The overall conclusions for each additional set of figure representations are generally similar and not repeated. 


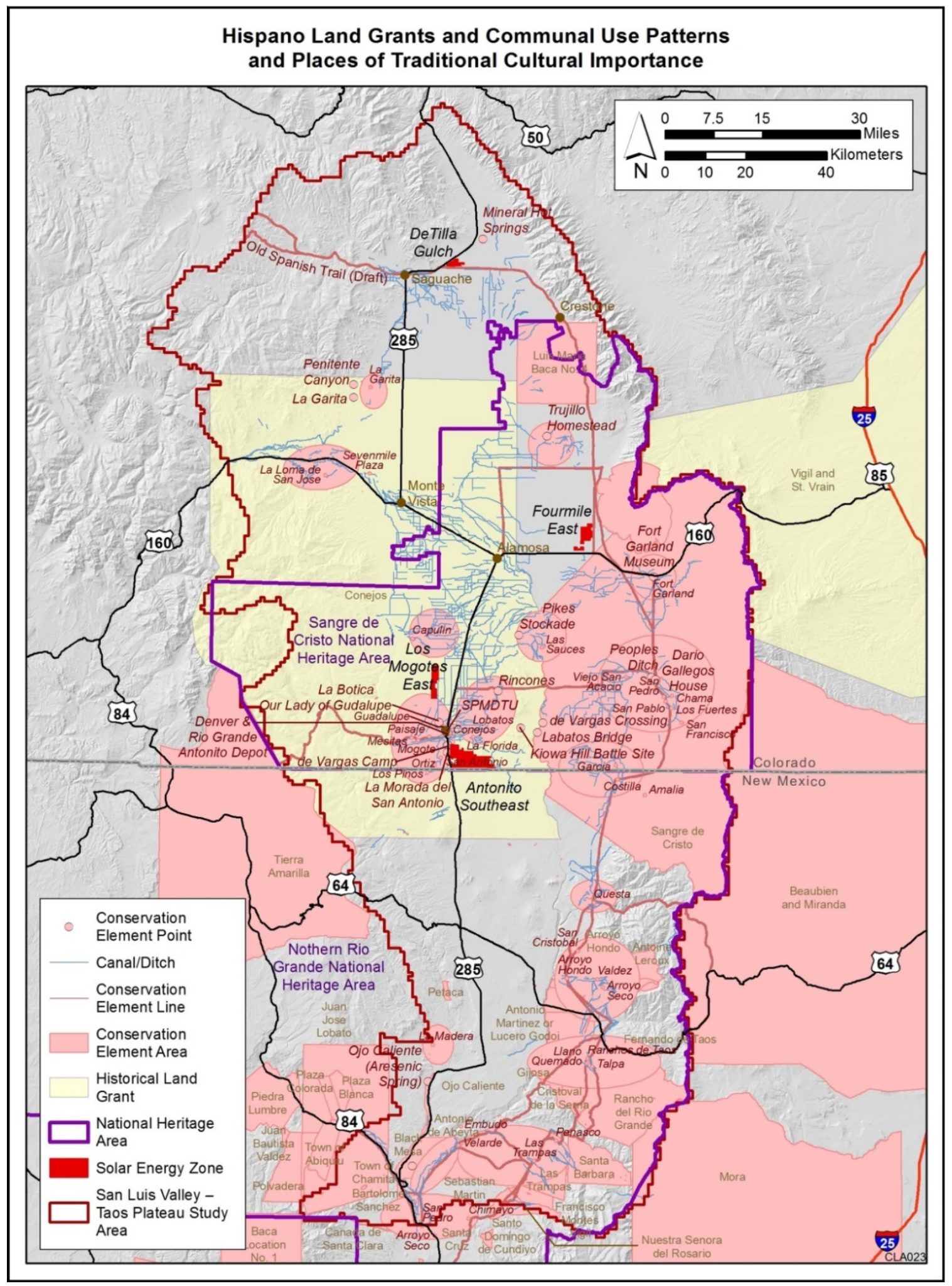

Figure B.4-1. Hispano Land Grants and Communal Land Use Patterns and Places of Traditional Cultural Importance 

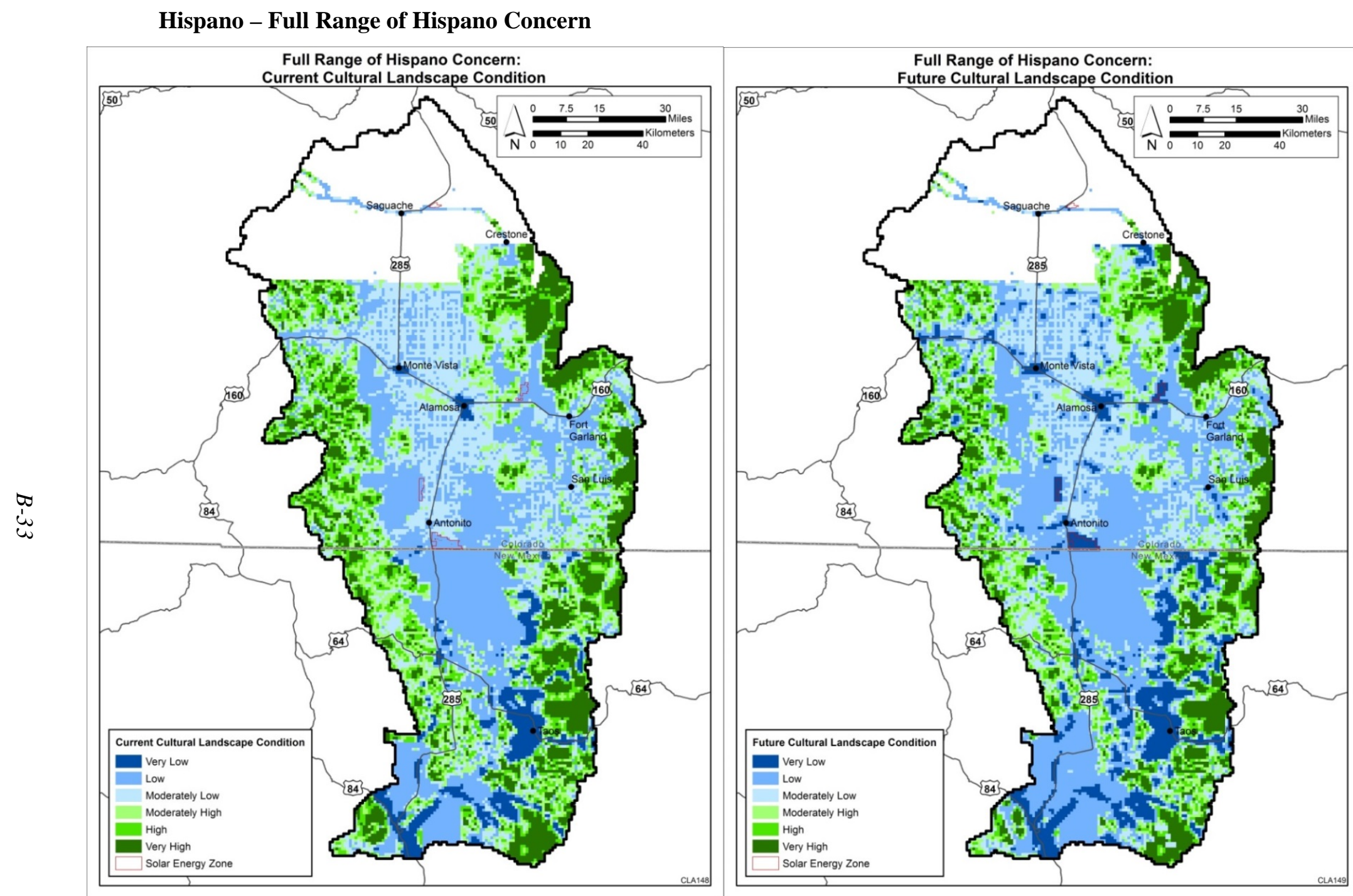

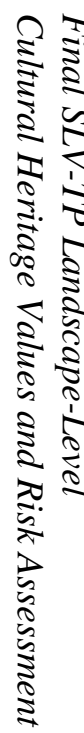

Figure B.4-2. Current and Future Landscape Condition of Hispano Land Grants, Communal Use Patterns, and Places of Traditional Cultural Importance 

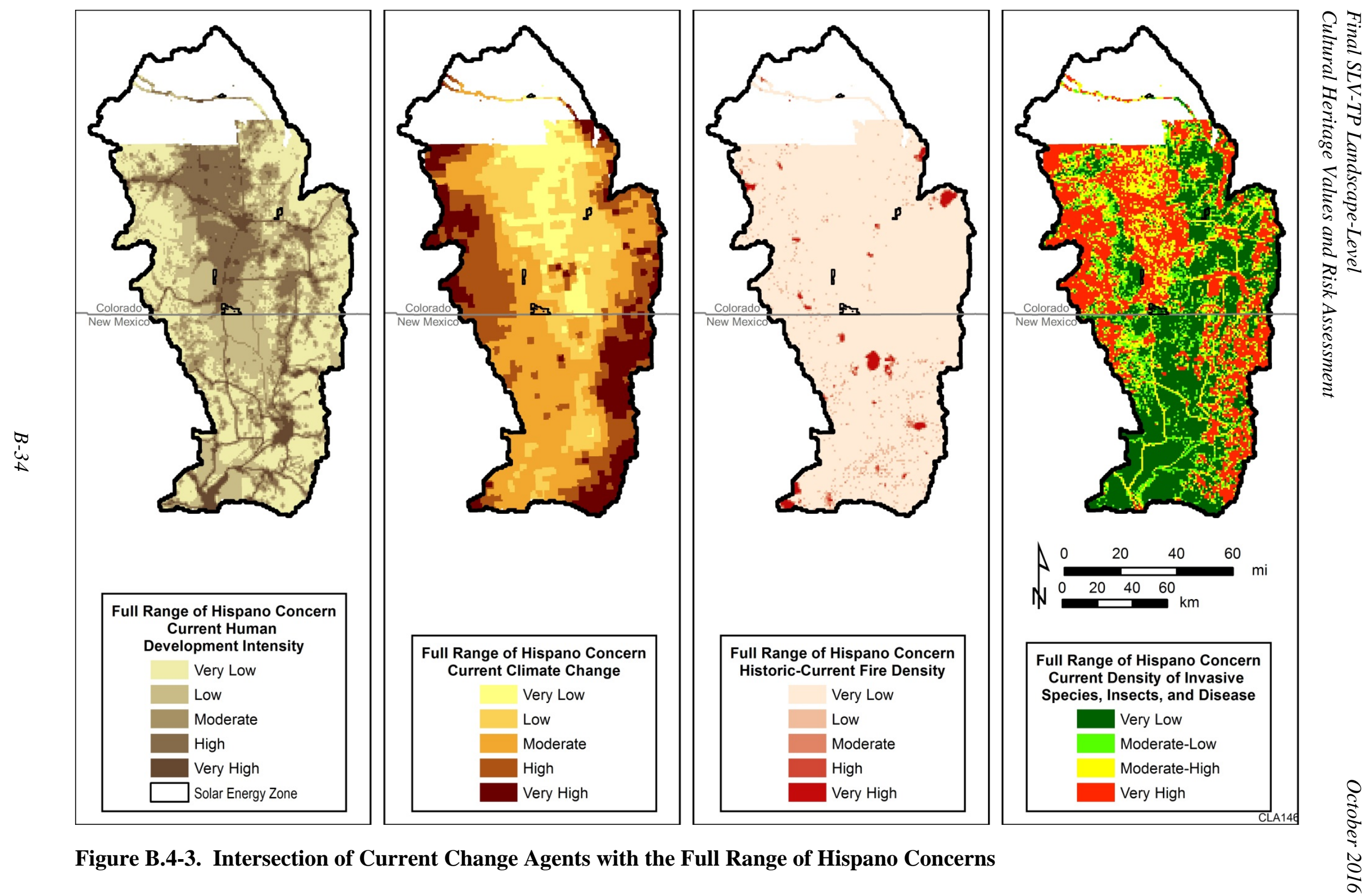

Figure B.4-3. Intersection of Current Change Agents with the Full Range of Hispano Concerns 

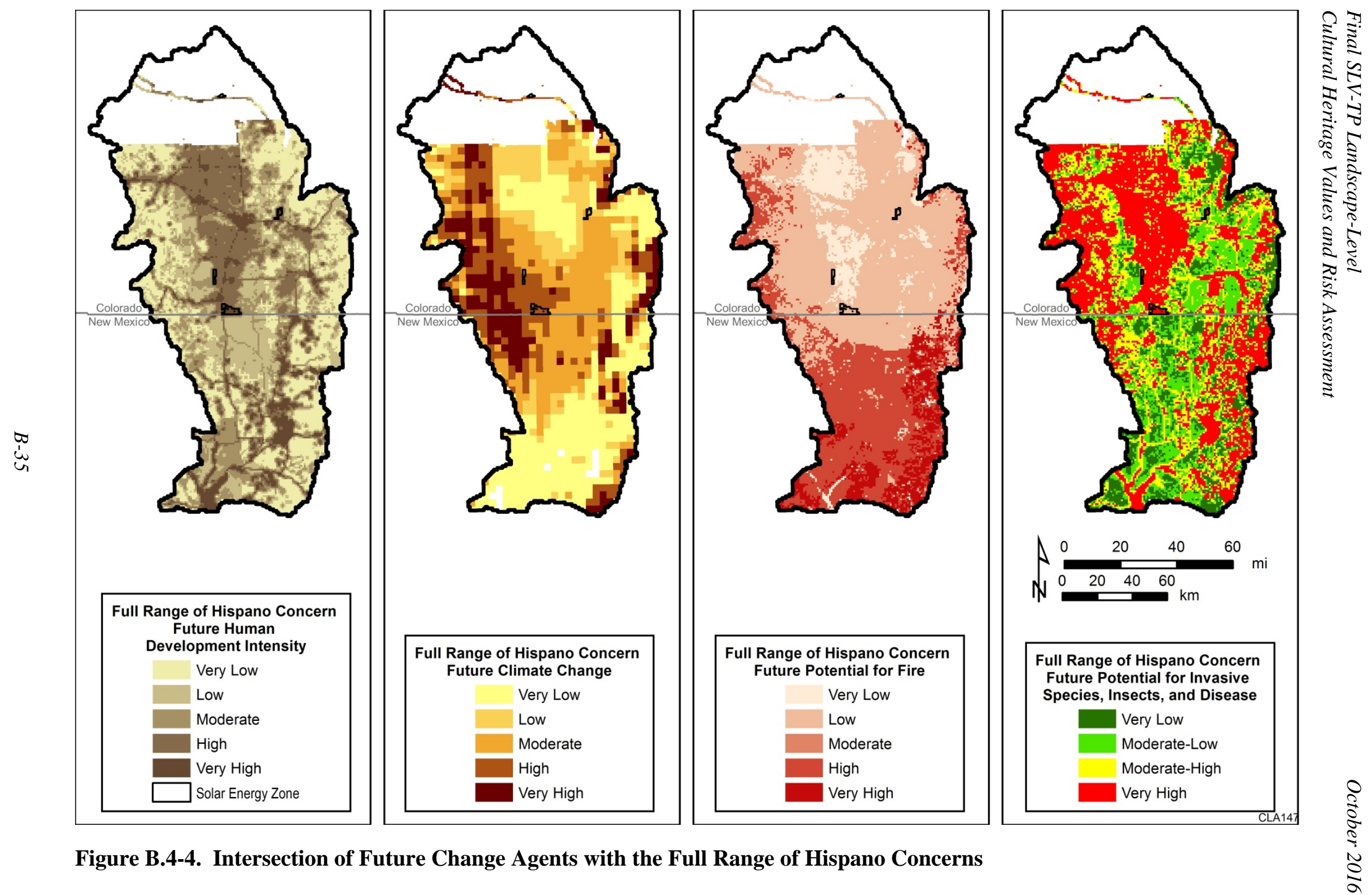

Figure B.4-4. Intersection of Future Change Agents with the Full Range of Hispano Concerns 

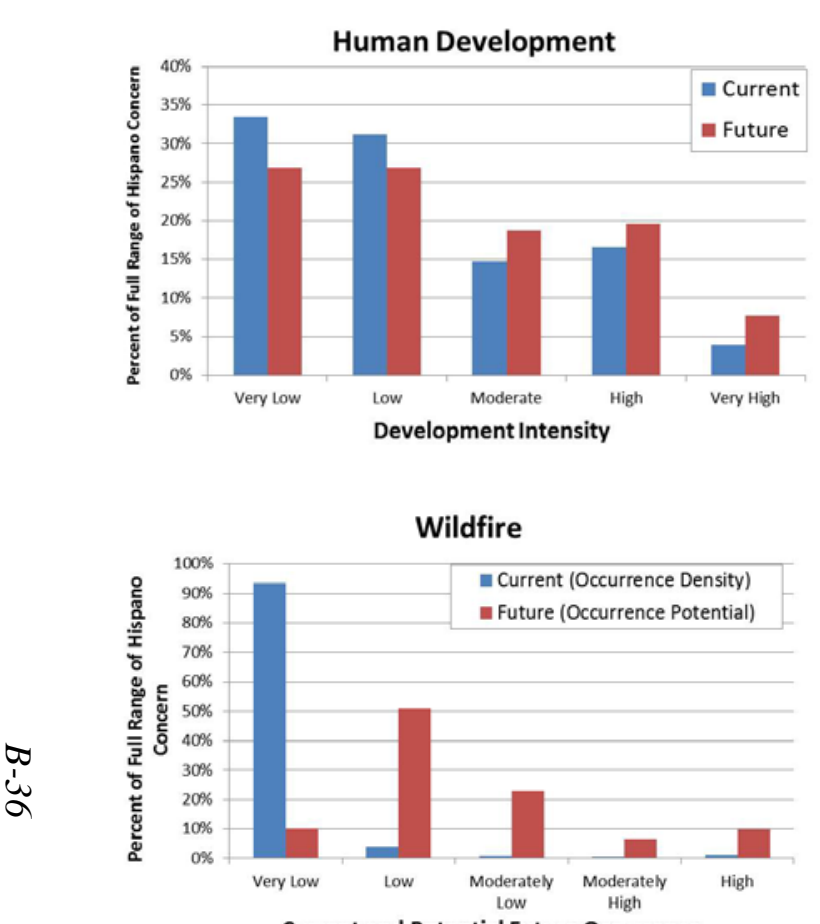

Current and Potential Future Occurrence

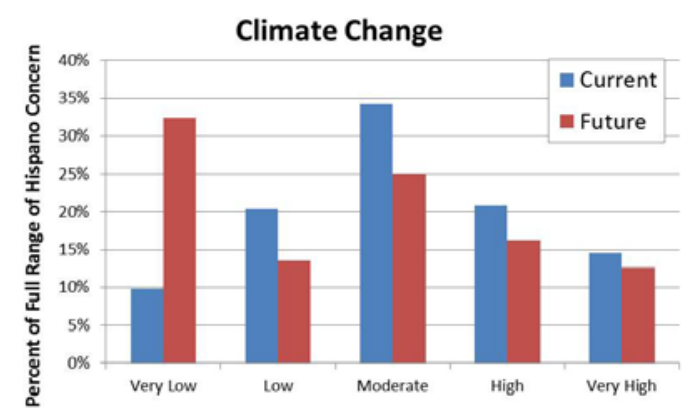

Potential for Climate Change

Invasive Species, Insects, and Disease

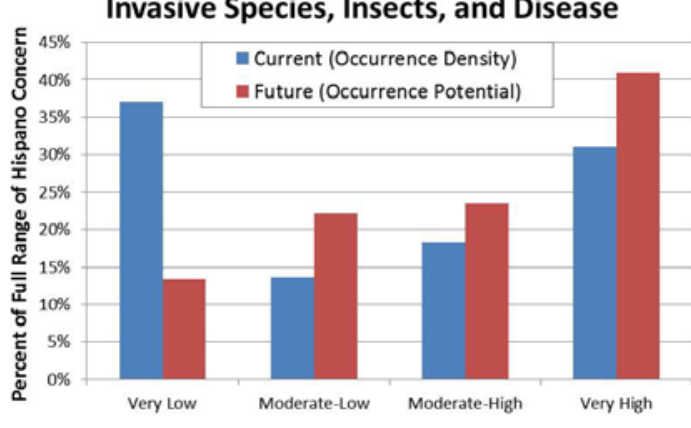

Current and Potential Future Occurrence

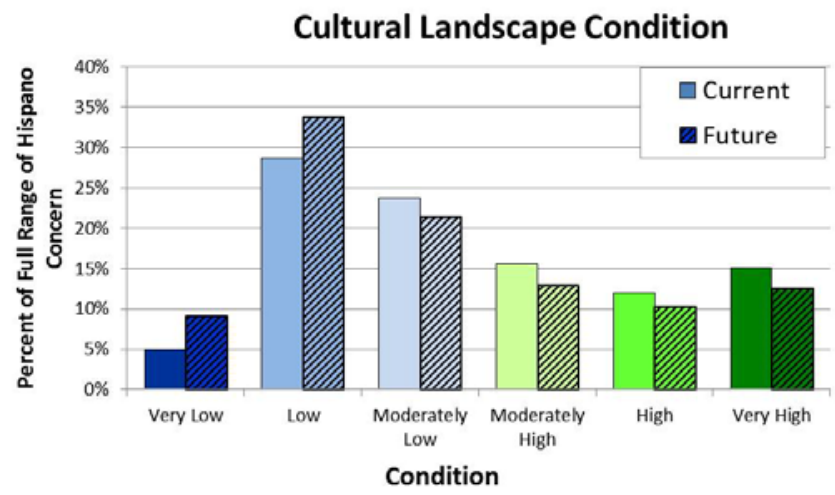

Figure B.4-5. Predicted Trends within the Full Range of Hispano Concerns 
Hispano - NHA

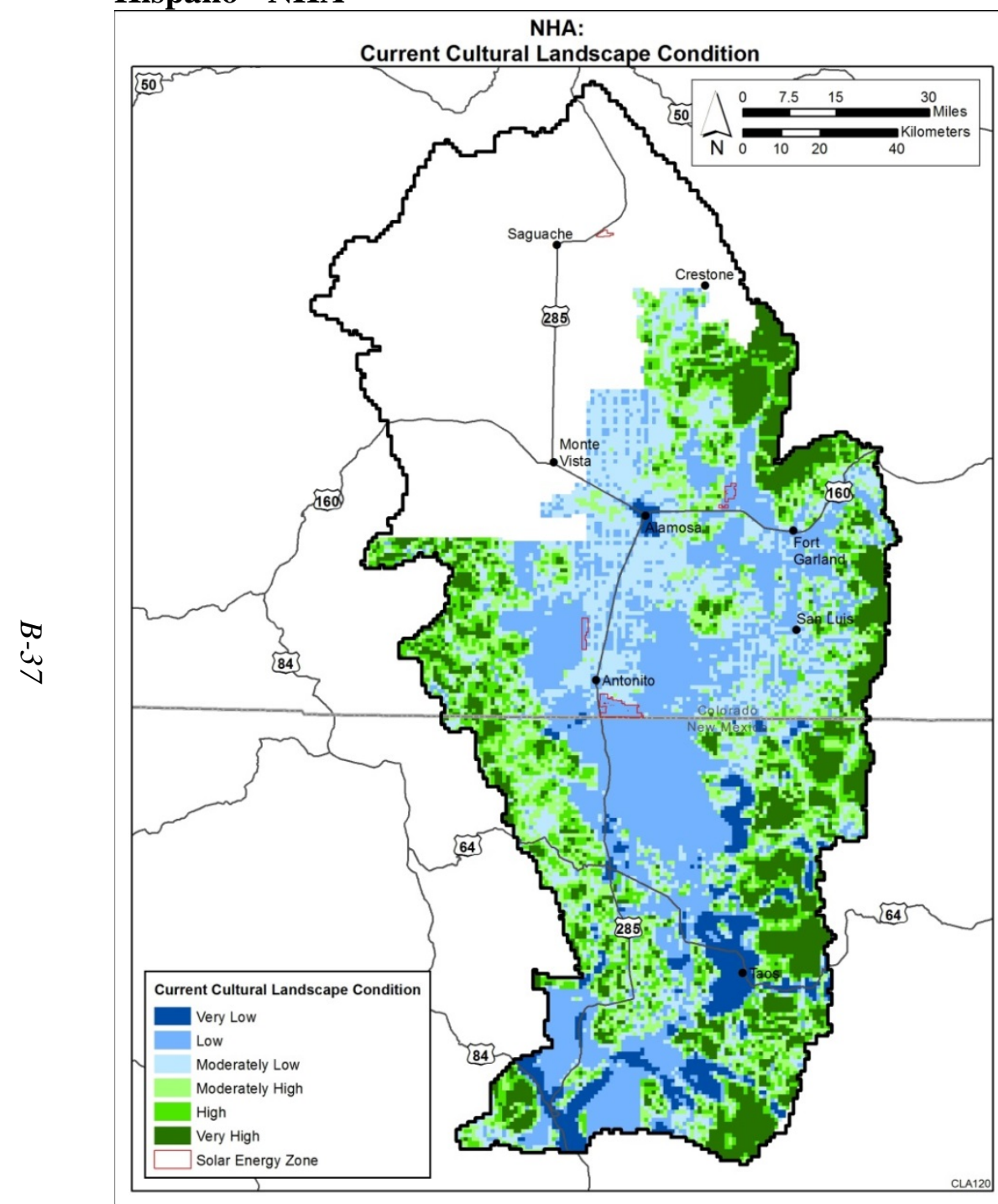

NHA:

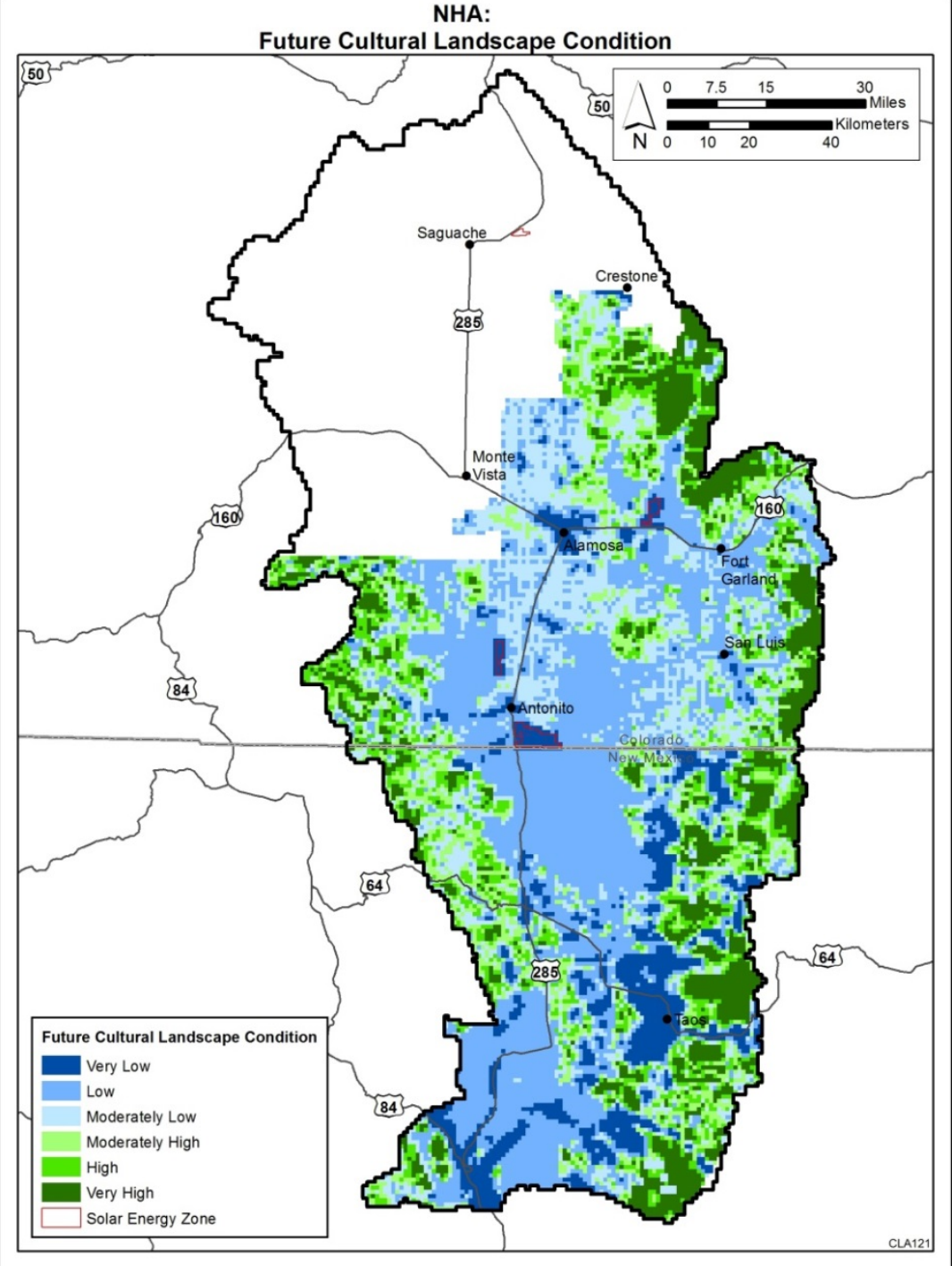

D

Figure B.4-6. Current and Future Landscape Condition of National Heritage Areas 

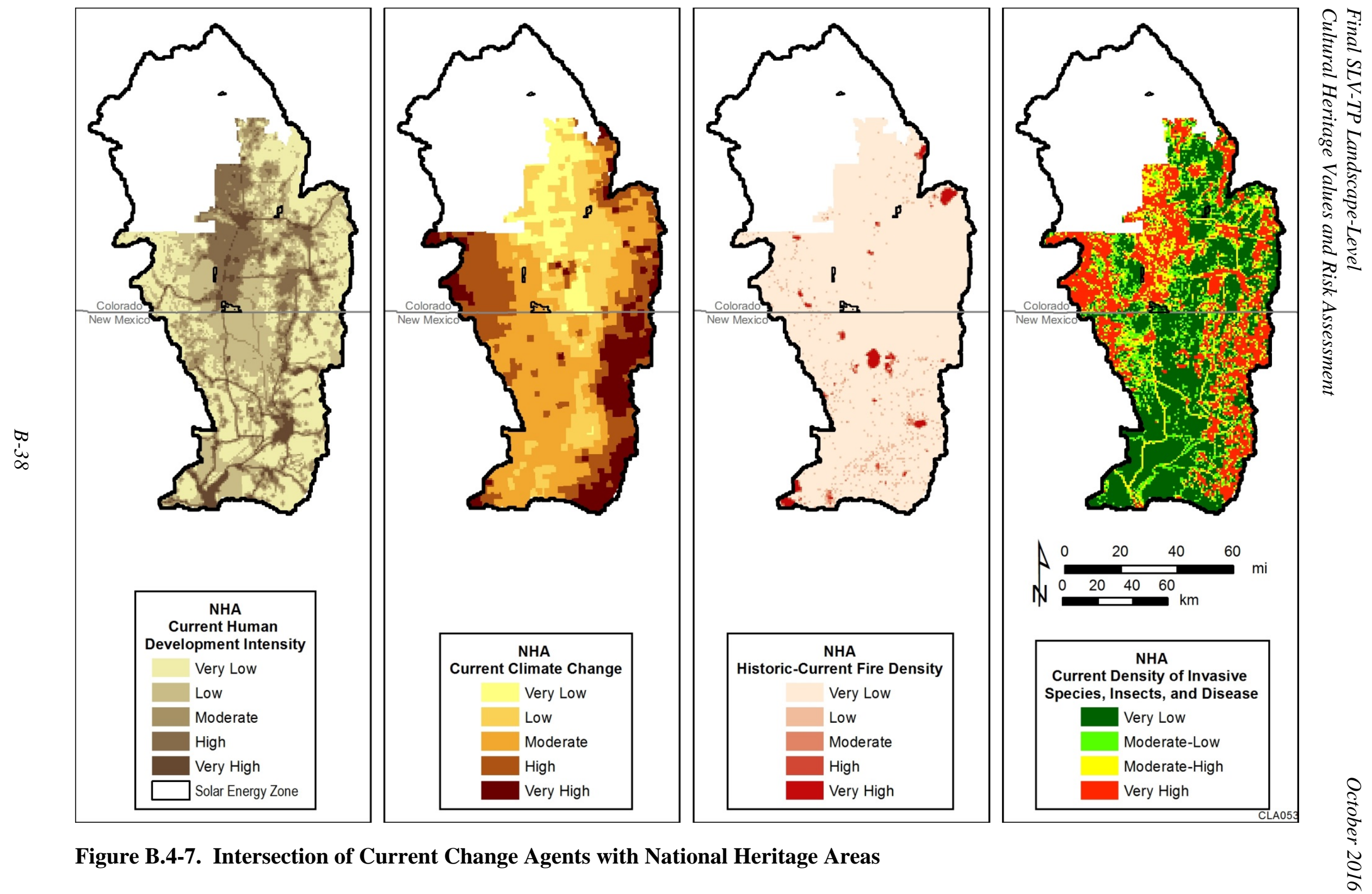

Figure B.4-7. Intersection of Current Change Agents with National Heritage Areas 

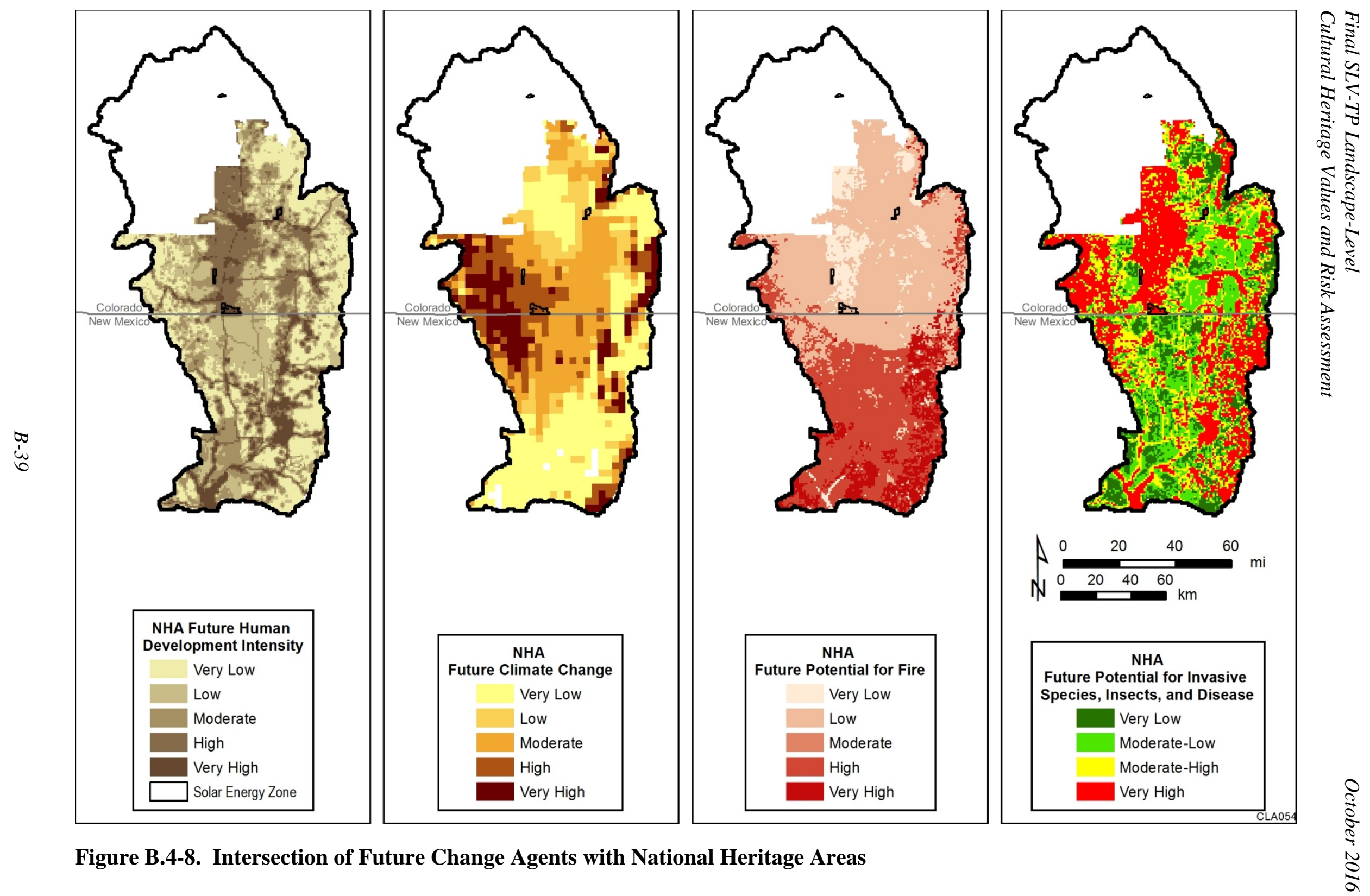

Figure B.4-8. Intersection of Future Change Agents with National Heritage Areas 

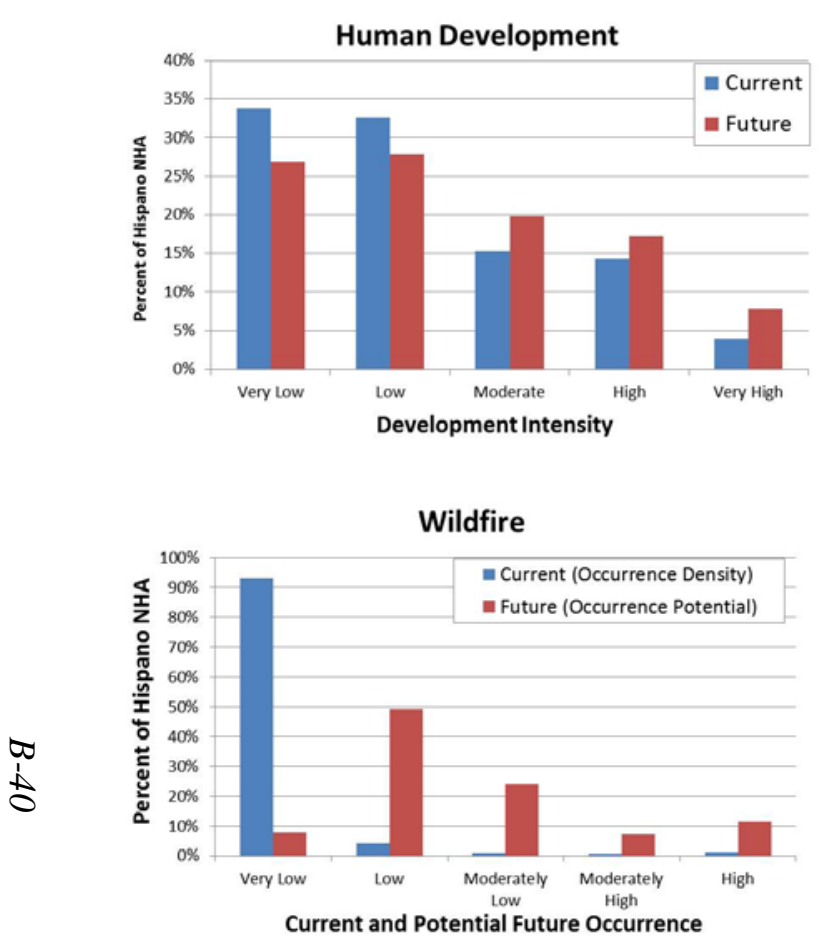

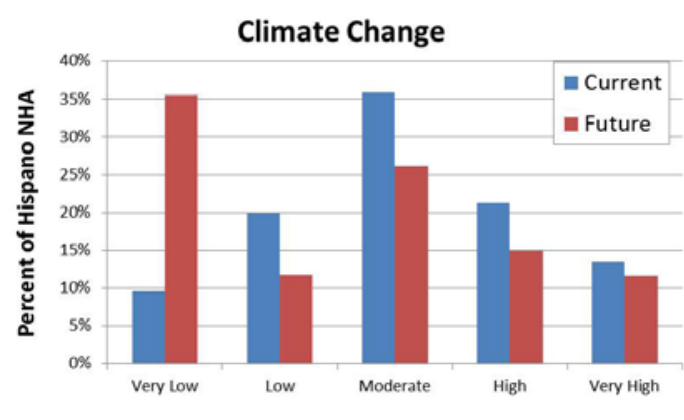

Potential for Climate Change

Invasive Species, Insects, and Disease

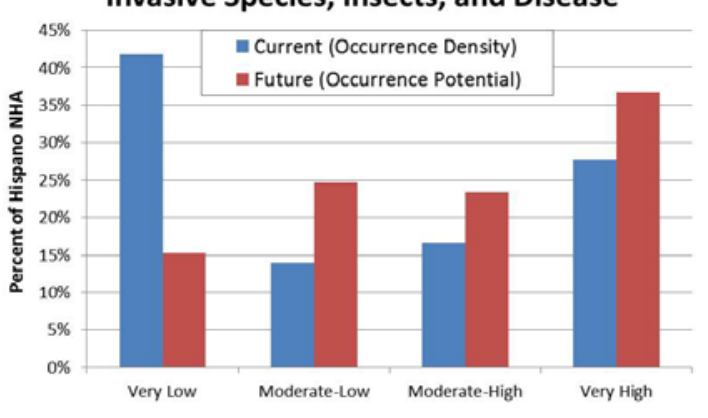

Current and Potential Future Occurrence

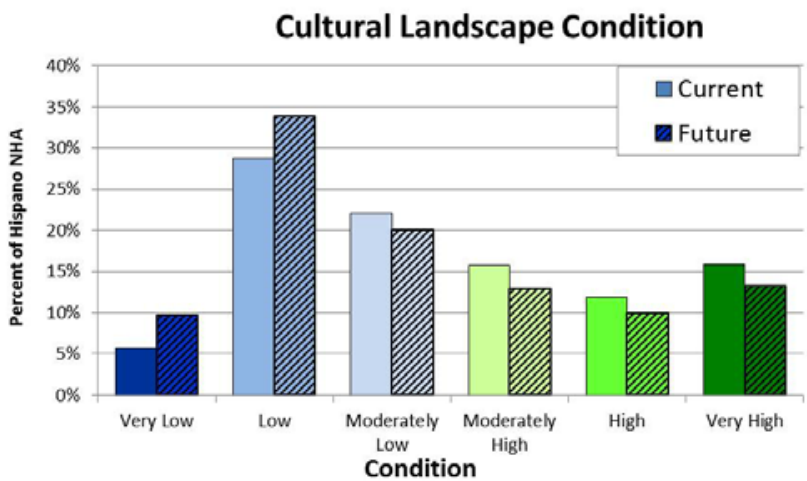

Figure B.4-9. Predicted Trends in National Heritage Areas within the Study Area 
Hispano - Land Grants

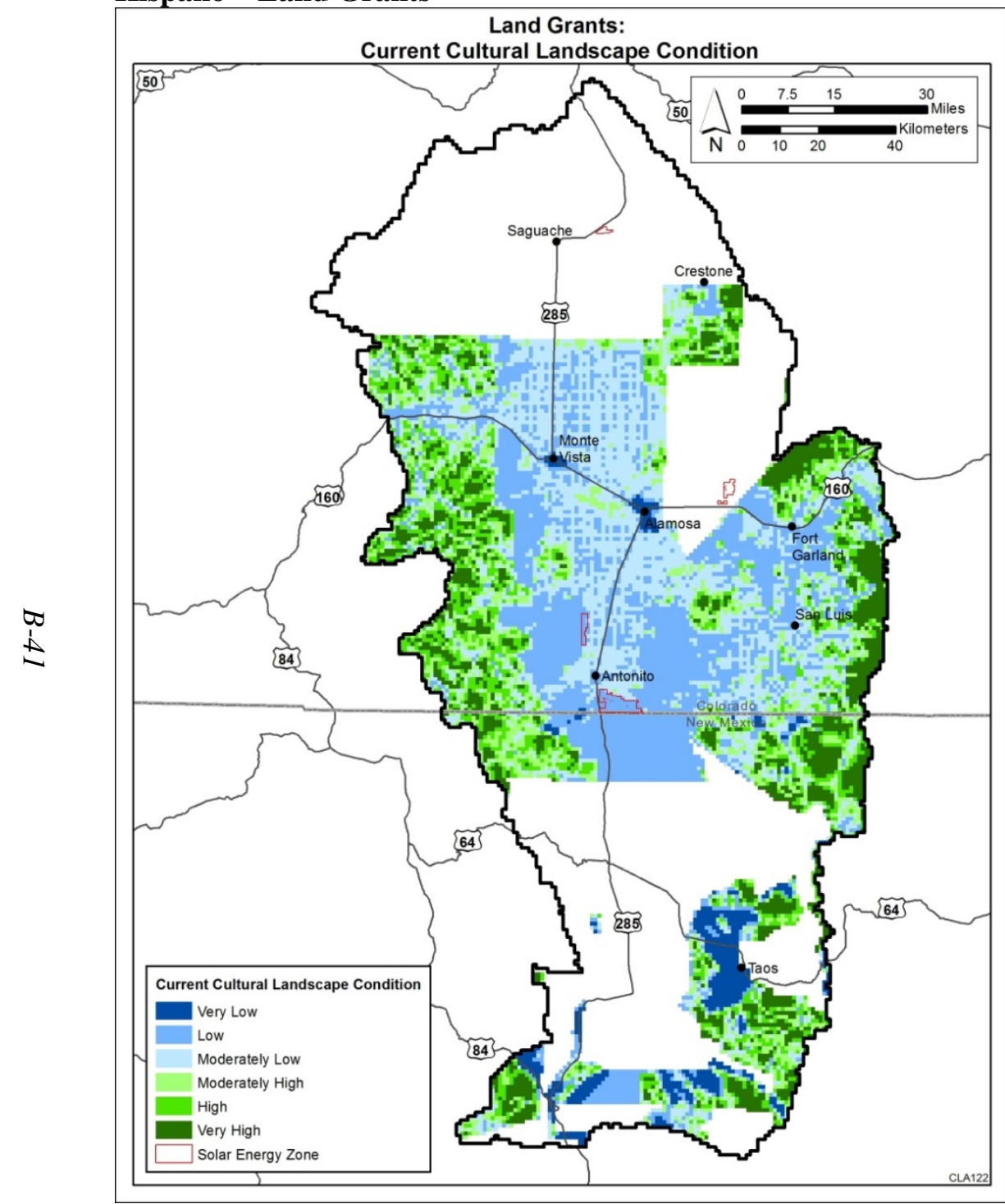

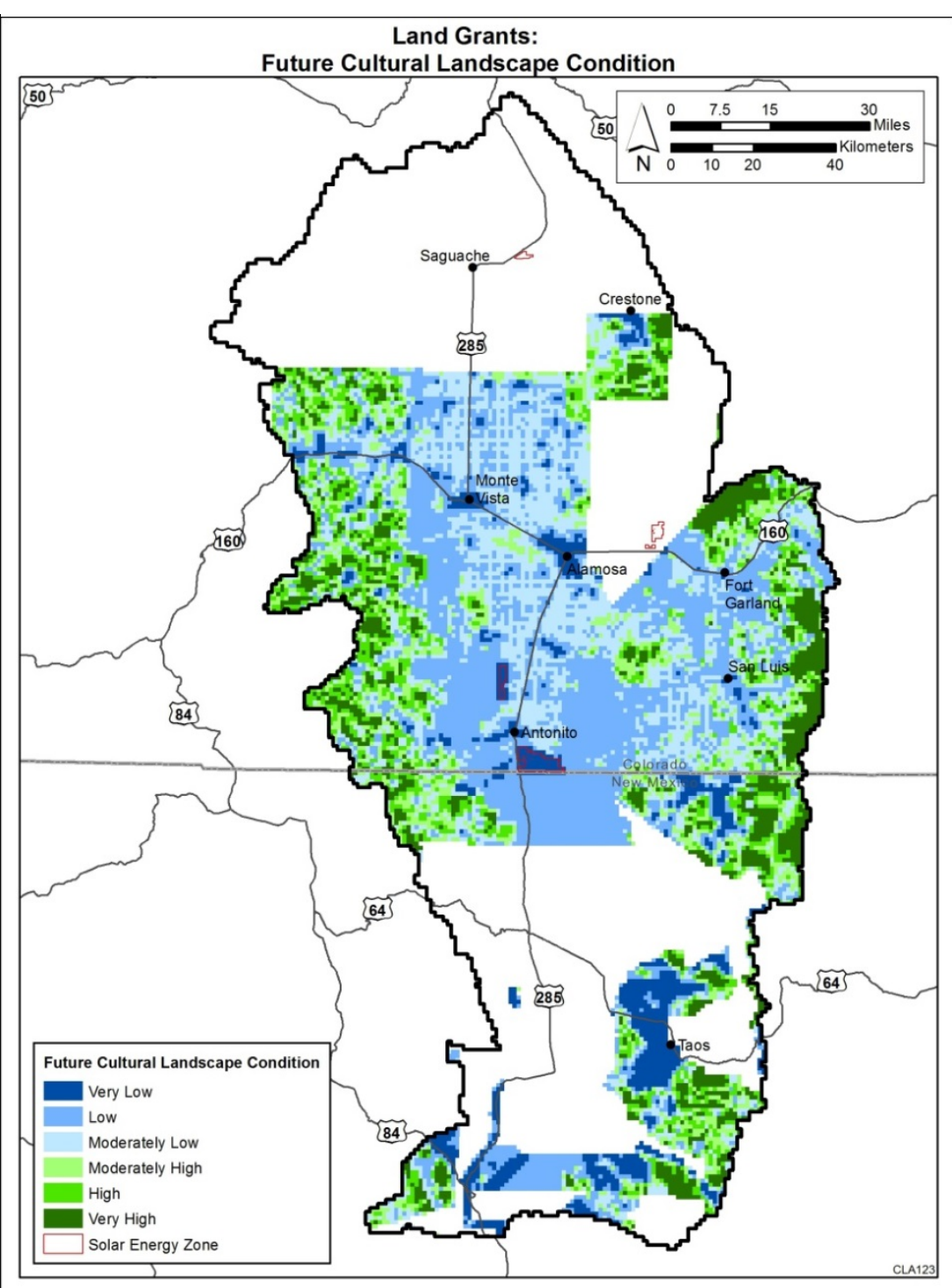

Figure B.4-10. Current and Future Landscape Condition of Hispano Land Grants 

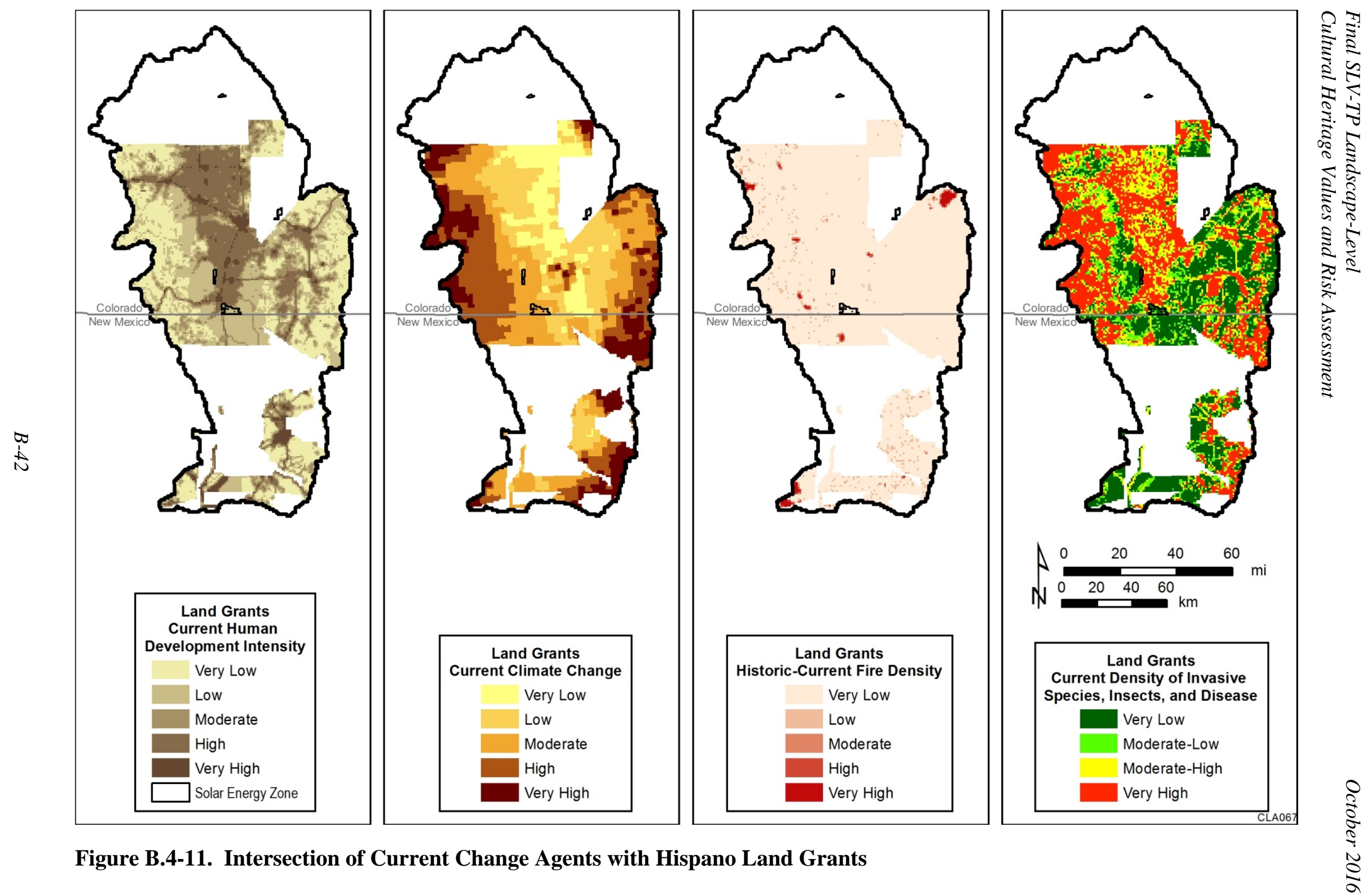

Figure B.4-11. Intersection of Current Change Agents with Hispano Land Grants 

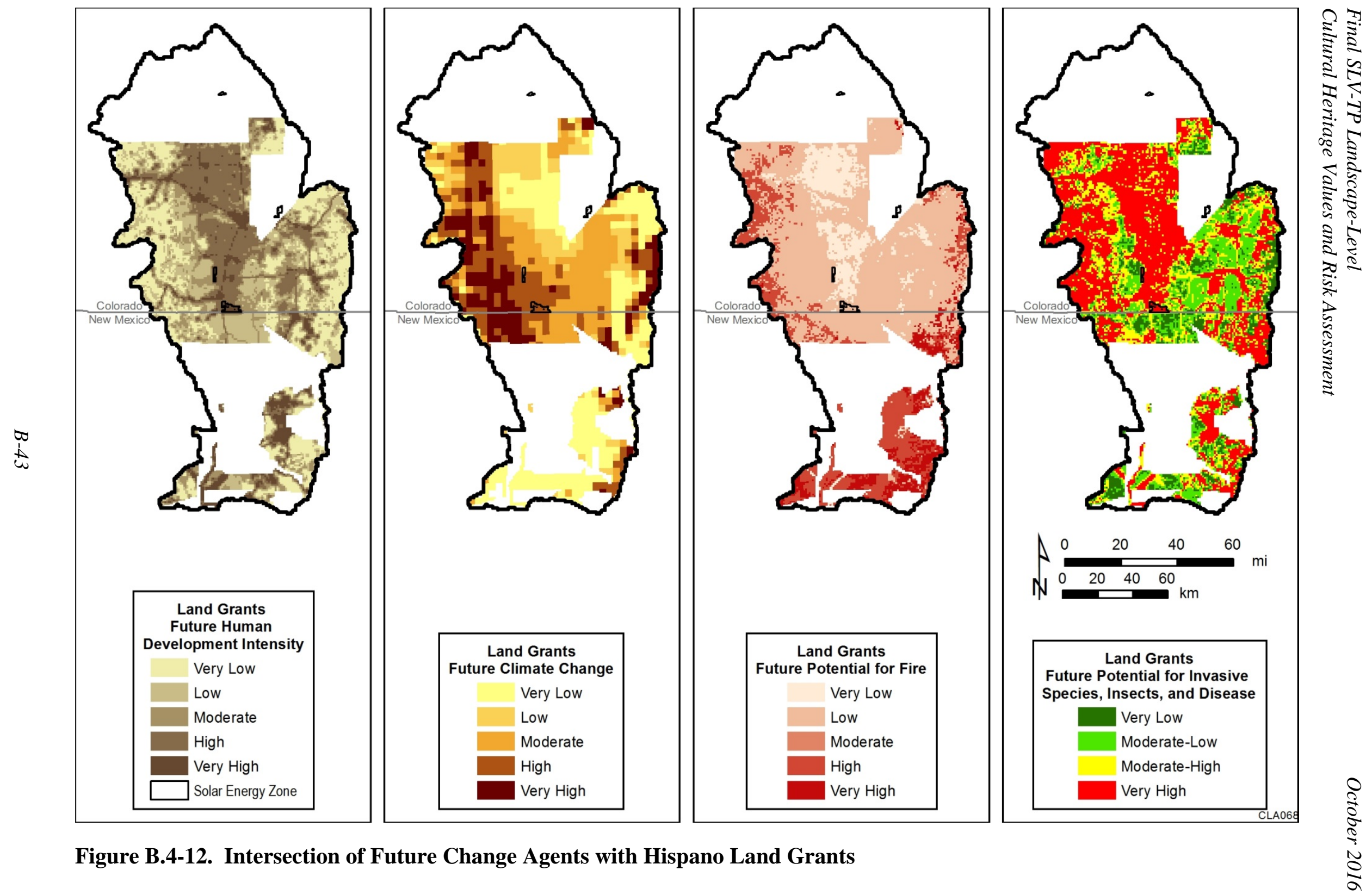

Figure B.4-12. Intersection of Future Change Agents with Hispano Land Grants 

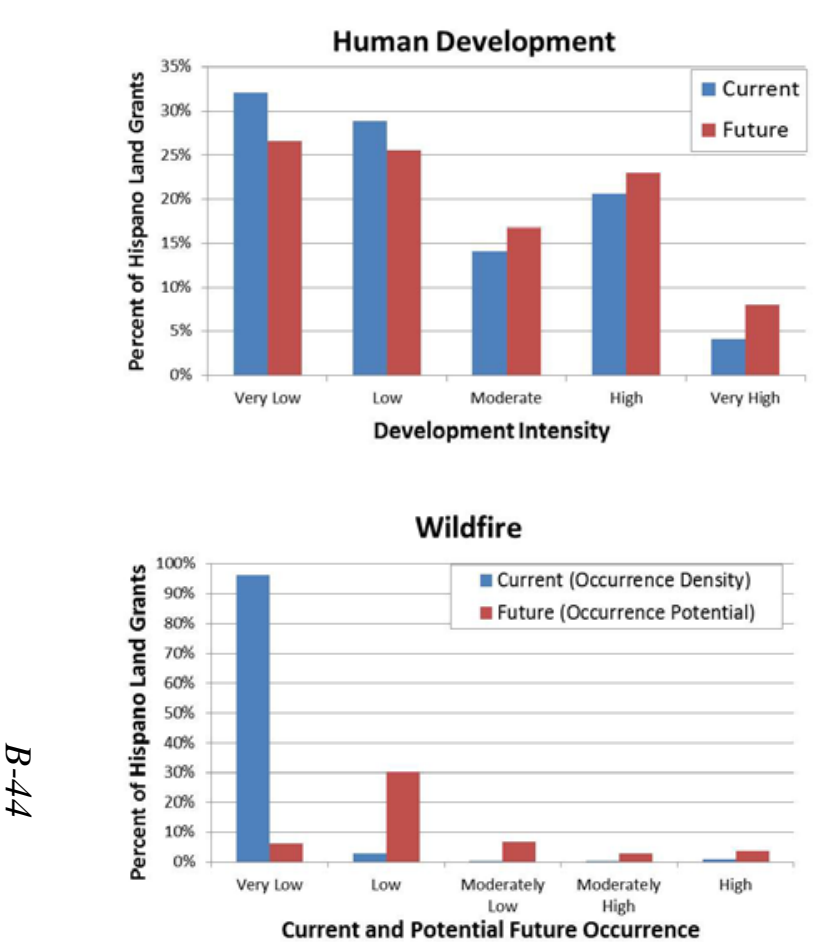

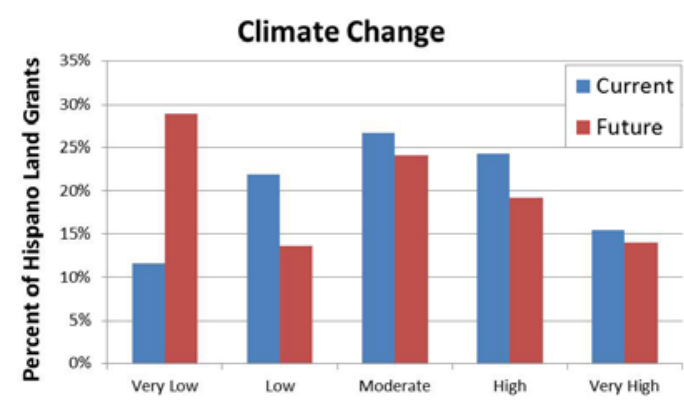

Potential for Climate Change

Invasive Species, Insects, and Disease

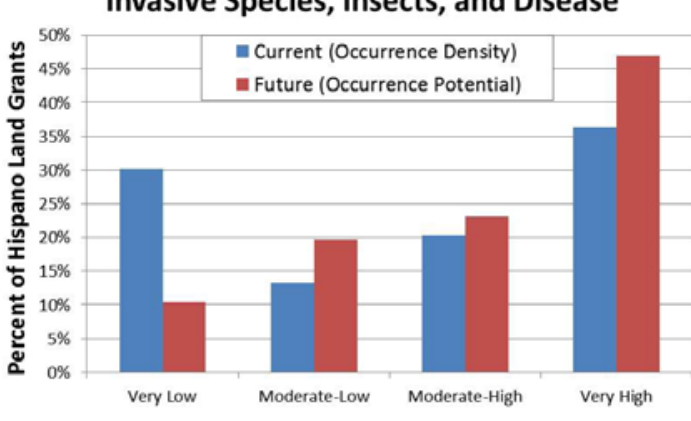

Current and Potential Future Occurrence

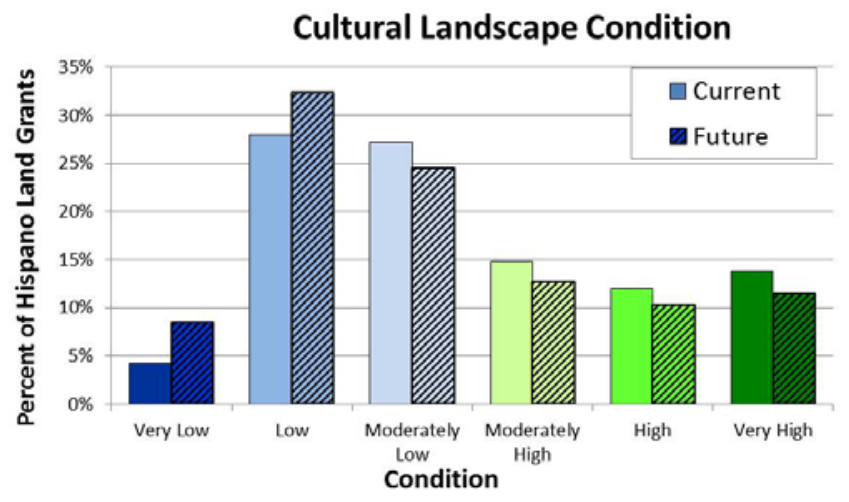

Figure B.4-13. Predicted Trends in Hispano Land Grants within the Study Area 


\section{Hispano - Conservation Element}

Hispano Land Grants and Communal Use Patterns and Places of Traditional

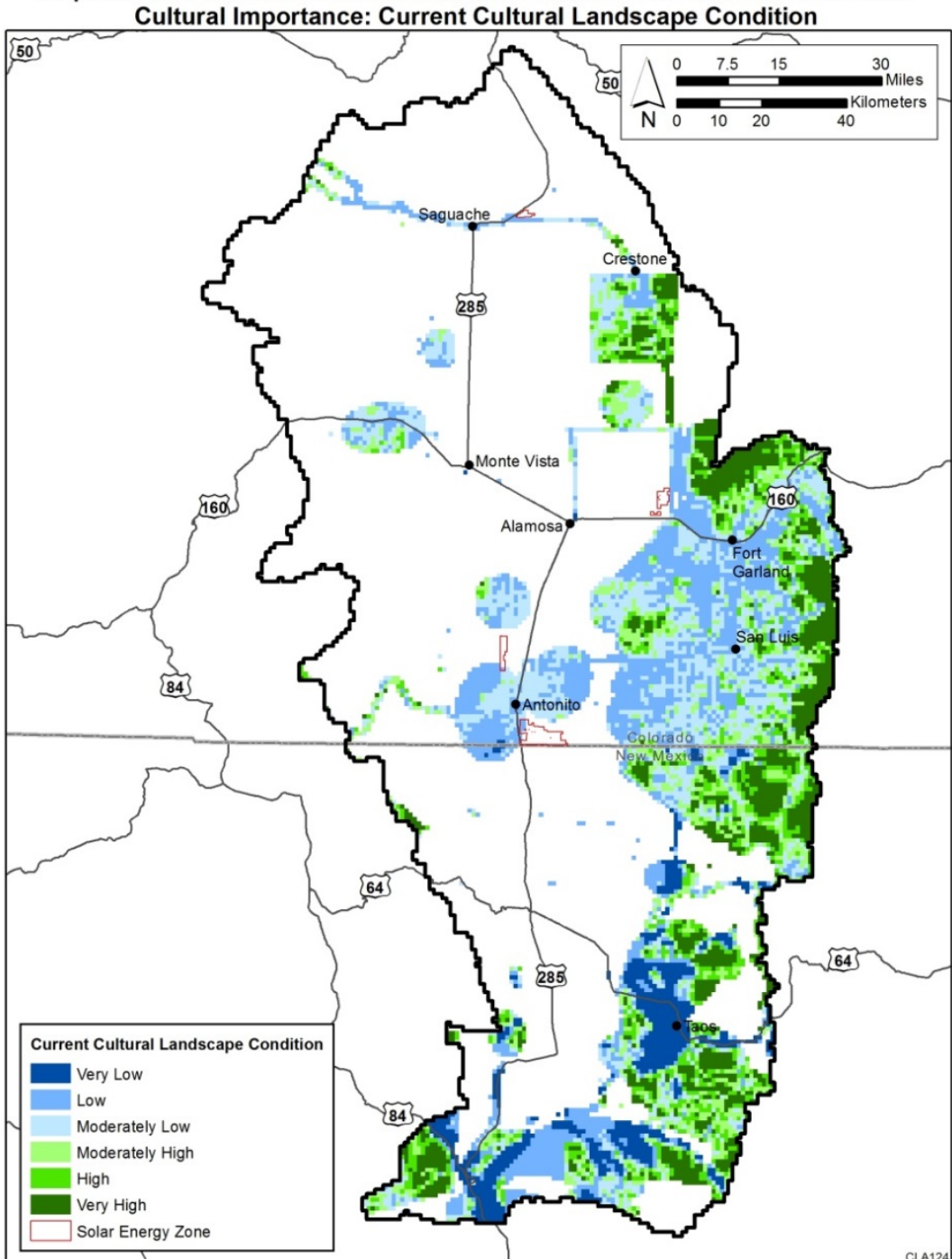

Hispano Land Grants and Communal Use Patterns and Places of Traditional

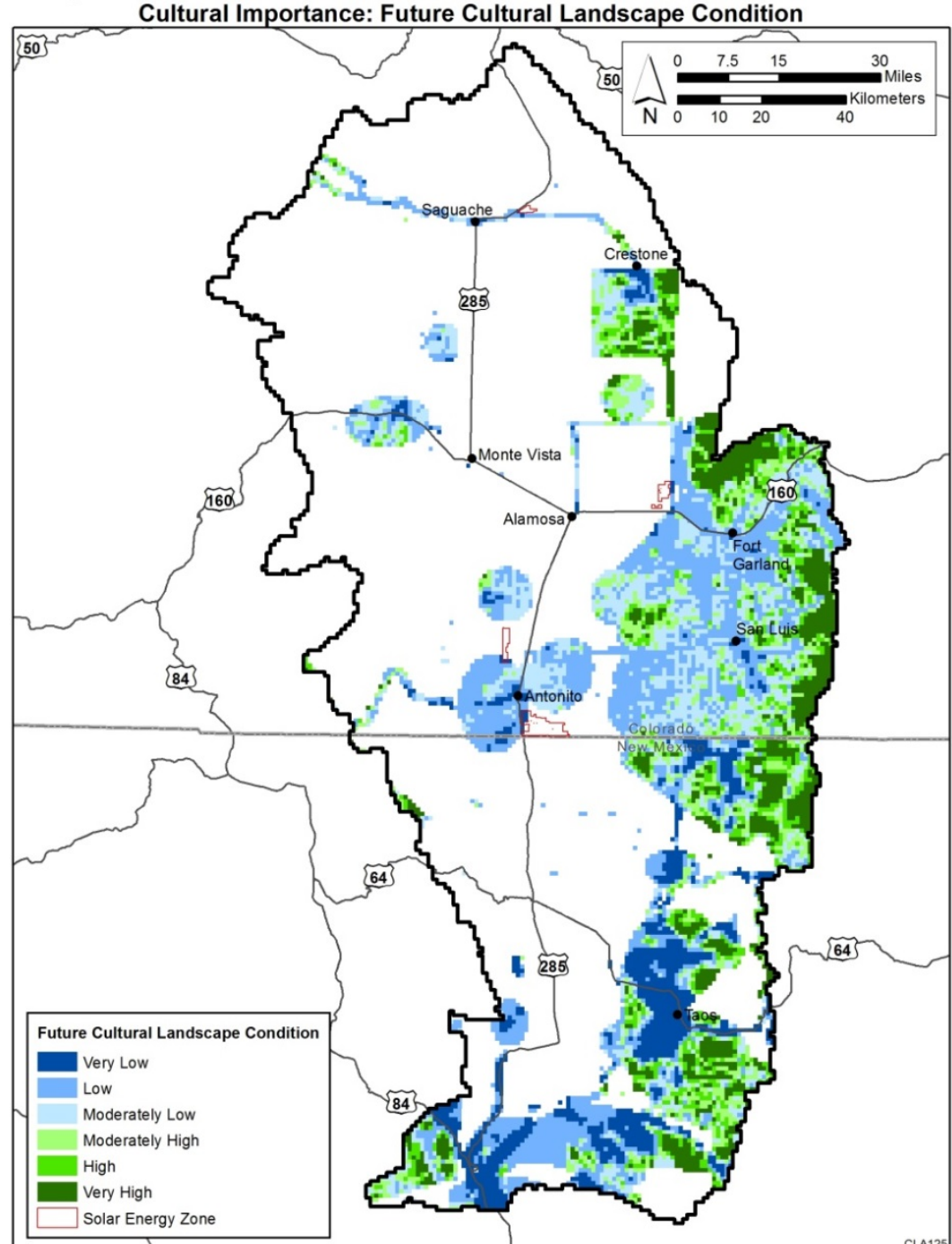

Figure B.4-14. Current and Future Landscape Condition of the Hispano Conservation Element 

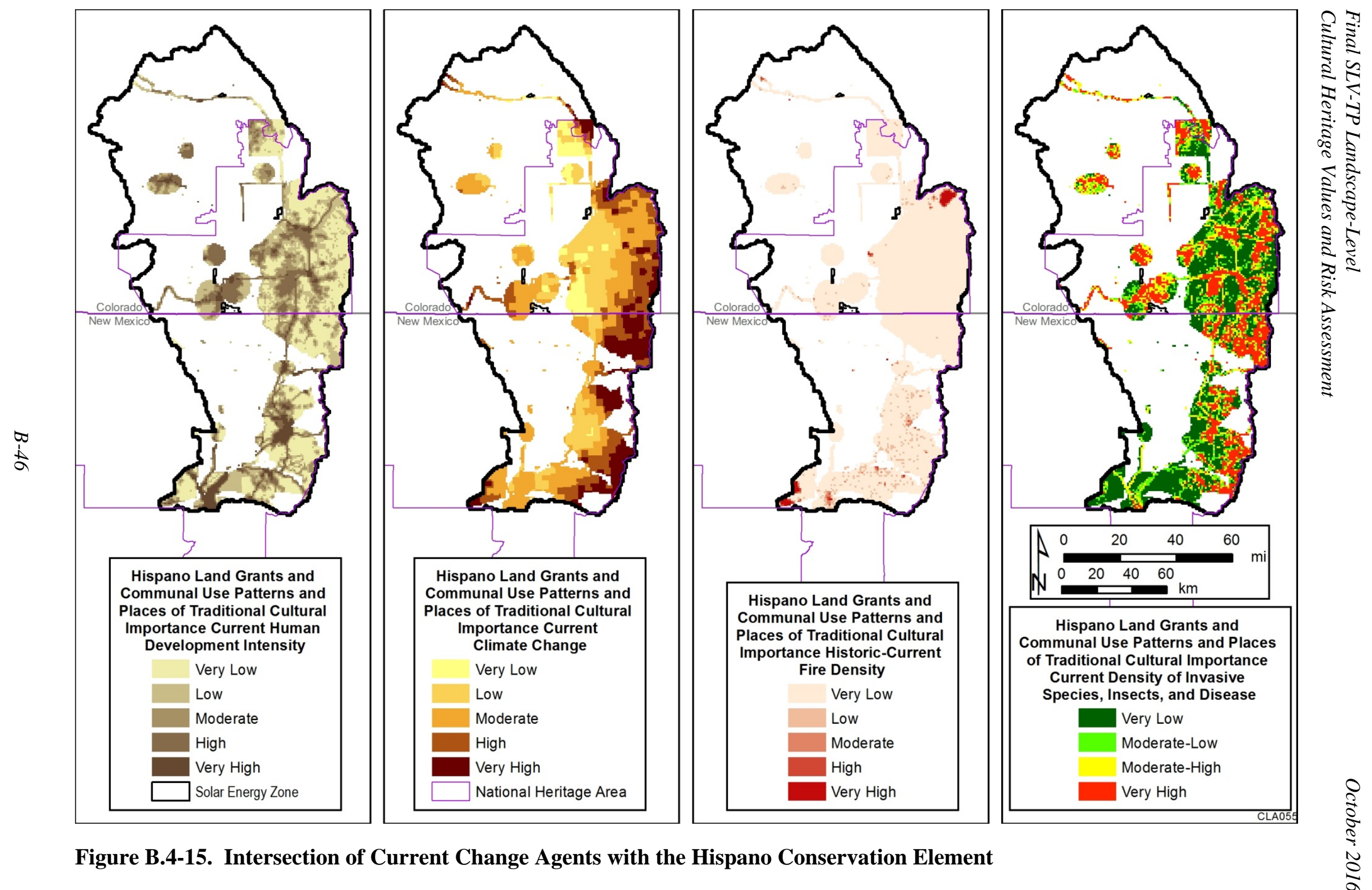

Figure B.4-15. Intersection of Current Change Agents with the Hispano Conservation Element

Hispano Land Grants and Communal Use Patterns and Places of Traditional Cultural Importance

Current Density of Invasive Species, Insects, and Disease

$$
\begin{aligned}
& \text { Very Low } \\
& \text { Moderate-Low } \\
& \text { Moderate-High } \\
& \text { Very High }
\end{aligned}
$$



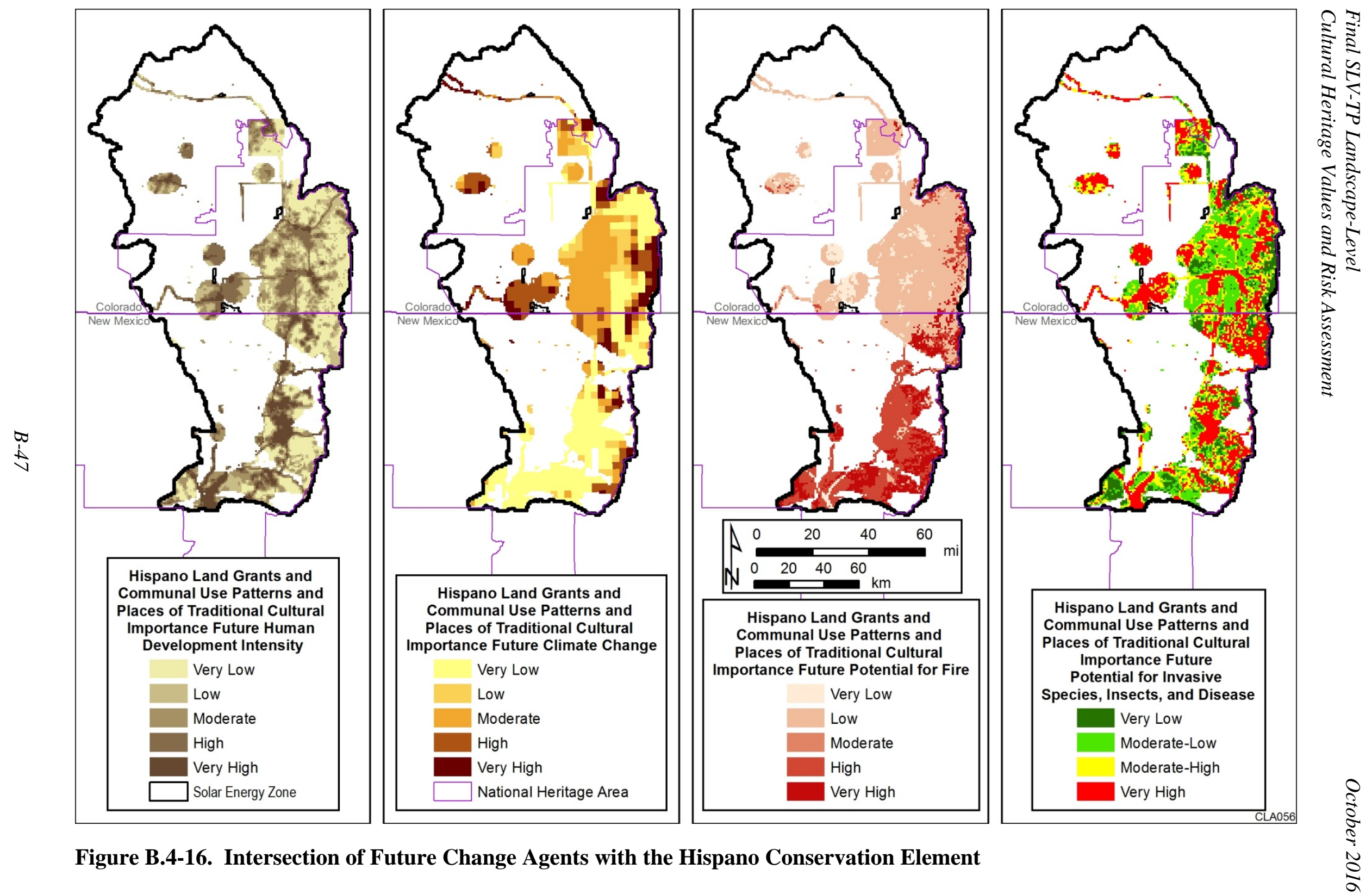

Figure B.4-16. Intersection of Future Change Agents with the Hispano Conservation Element 

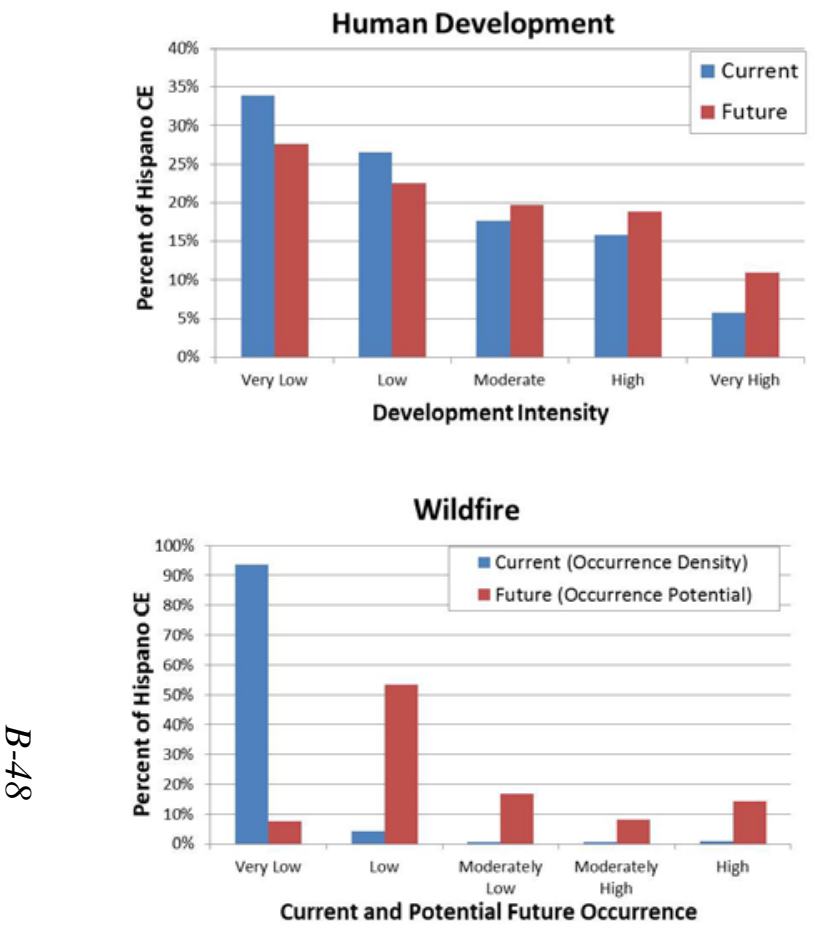

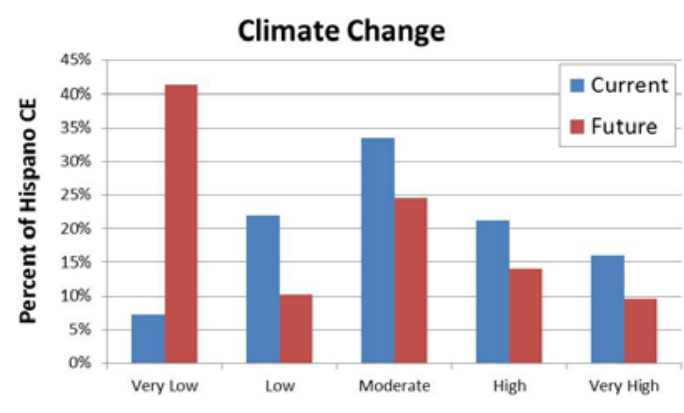

Potential for Climate Change

Invasive Species, Insects, and Disease

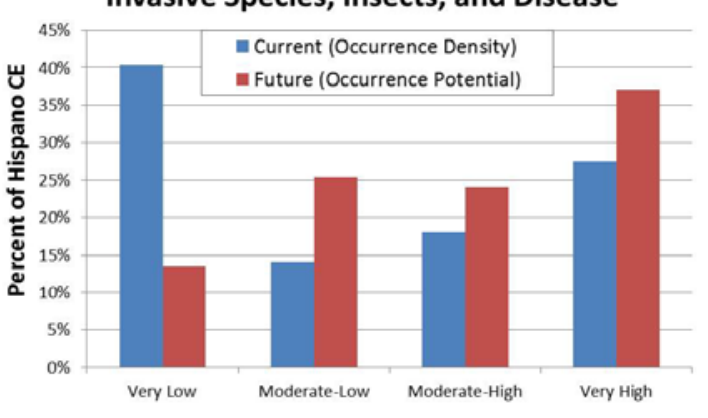

Current and Potential Future Occurrence

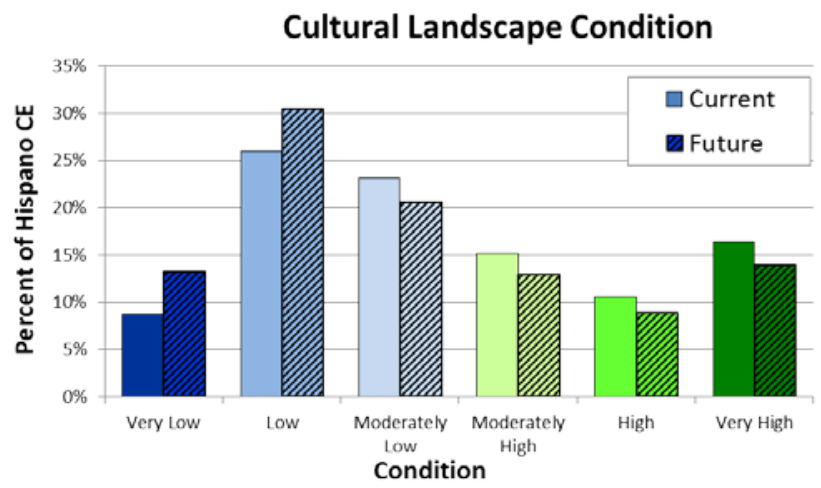

Figure B.4-17. Predicted Trends in the Hispano Conservation Element within the Study Area 


\section{B.5 Paleontology}

This conservation element represents areas within the valley that have important paleontological research value. Only one major area of paleontological importance, a mammoth bone concentration near the De Tilla Gulch SEZ, was identified within the study area, although others areas, like the Sombrillo ACEC south of the study area in New Mexico, are known to occur just outside of the study area boundary.

Figure B.5-1 shows the spatial extent of the paleontology conservation element as derived by the field experts, and Figure B.5-2 illustrates current and future cultural landscape condition for the paleontological area based on the modeling described in Section 4.2.2. Figures B.5-3 and B.5-4 shows the paleontology conservation element intersected with each of the relevant change agents separately at current and future conditions, respectively. Note that the wildfire and invasive species change agents are not expected to affect this particular resource. The change agent models are identical to those used for the Landscape Assessment and details on their derivations are described in full in that document (Walston et al. 2016). The bar graphs in Figure B.5-5 (based on data presented in Table B-2) are intended to show the trends from current condition to future condition based on percentage of the area affected. Although the area represented by this conservation element is small, it is located between Saguache and Crestone and contains one of the solar energy zones (DeTilla Gulch), so there is an anticipated increase in human development within this area (approximately 22\% increase in high and very high levels of development by the year 2030). Although the data show low levels of change in precipitation and temperature from historic times to present, an increase to high and very high climate change effects (changes in precipitation and temperature) of $57 \%$ of the area is projected in the future (by 2060). Also depicted in Figure B.5-5 is a steady reduction in cultural landscape condition. 


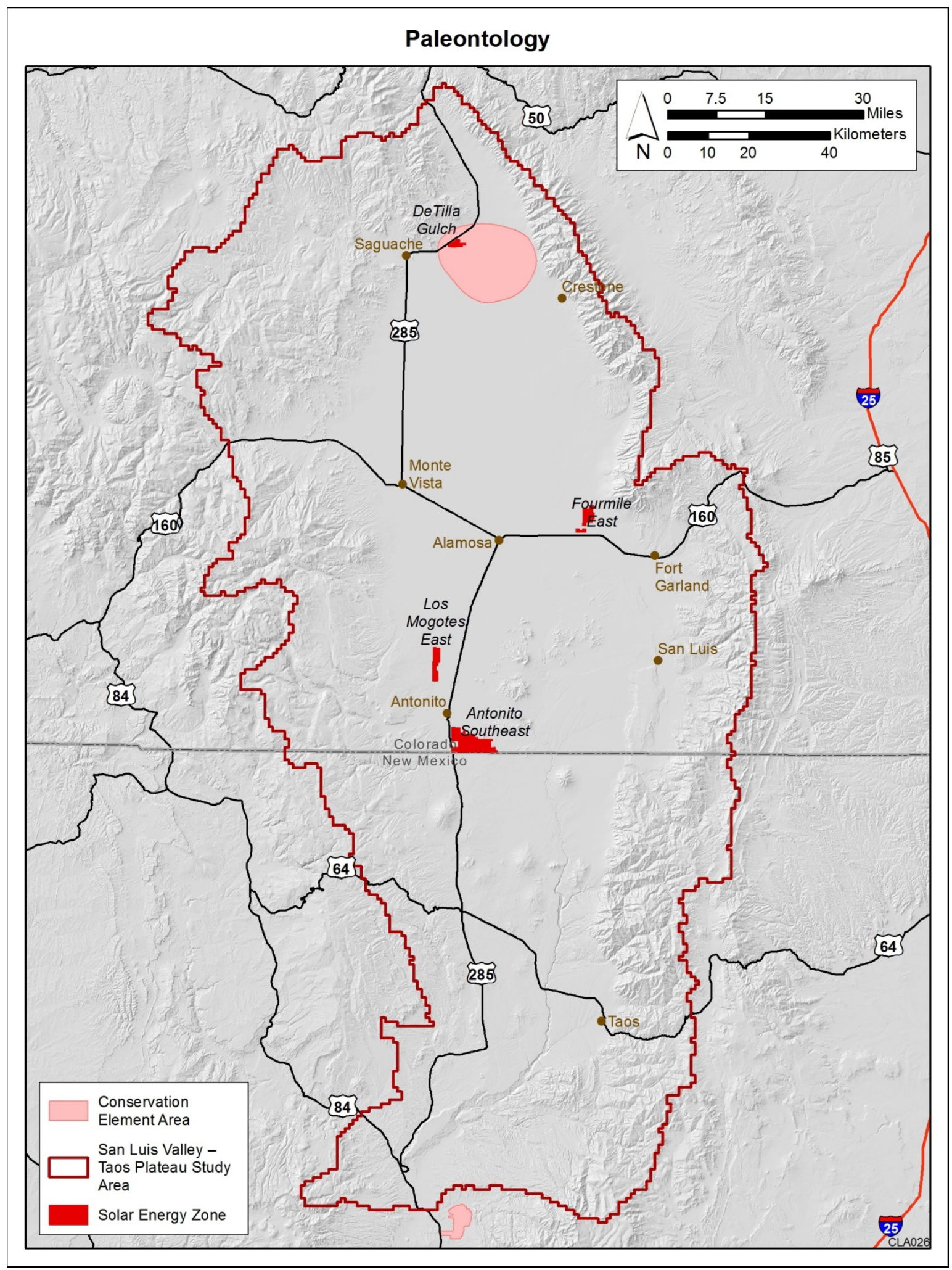

Figure B.5-1. Current Distribution of the Paleontology Conservation Element 


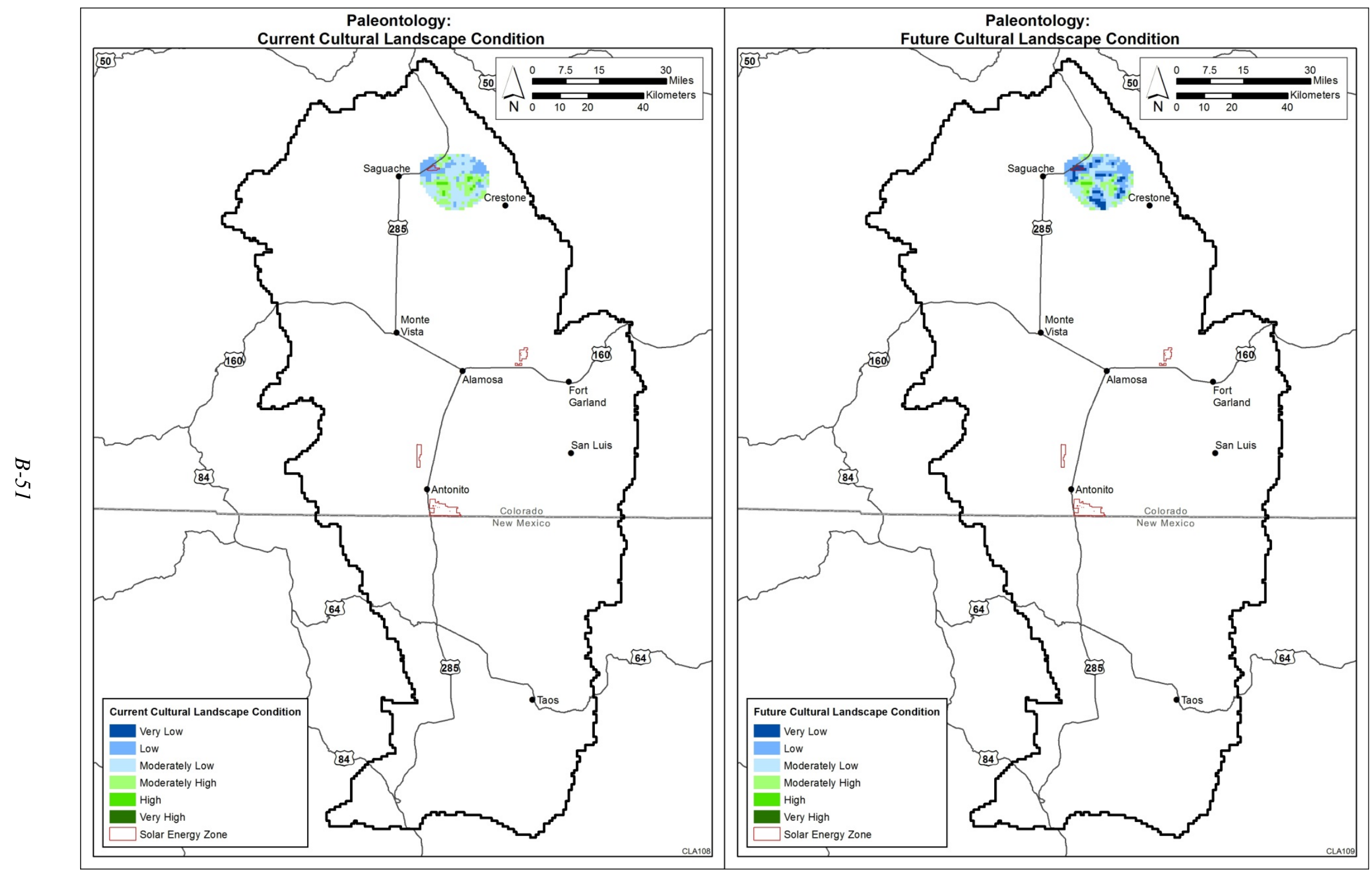

Figure B.5-2. Current and Future Landscape Condition of the Paleontology Conservation Element 

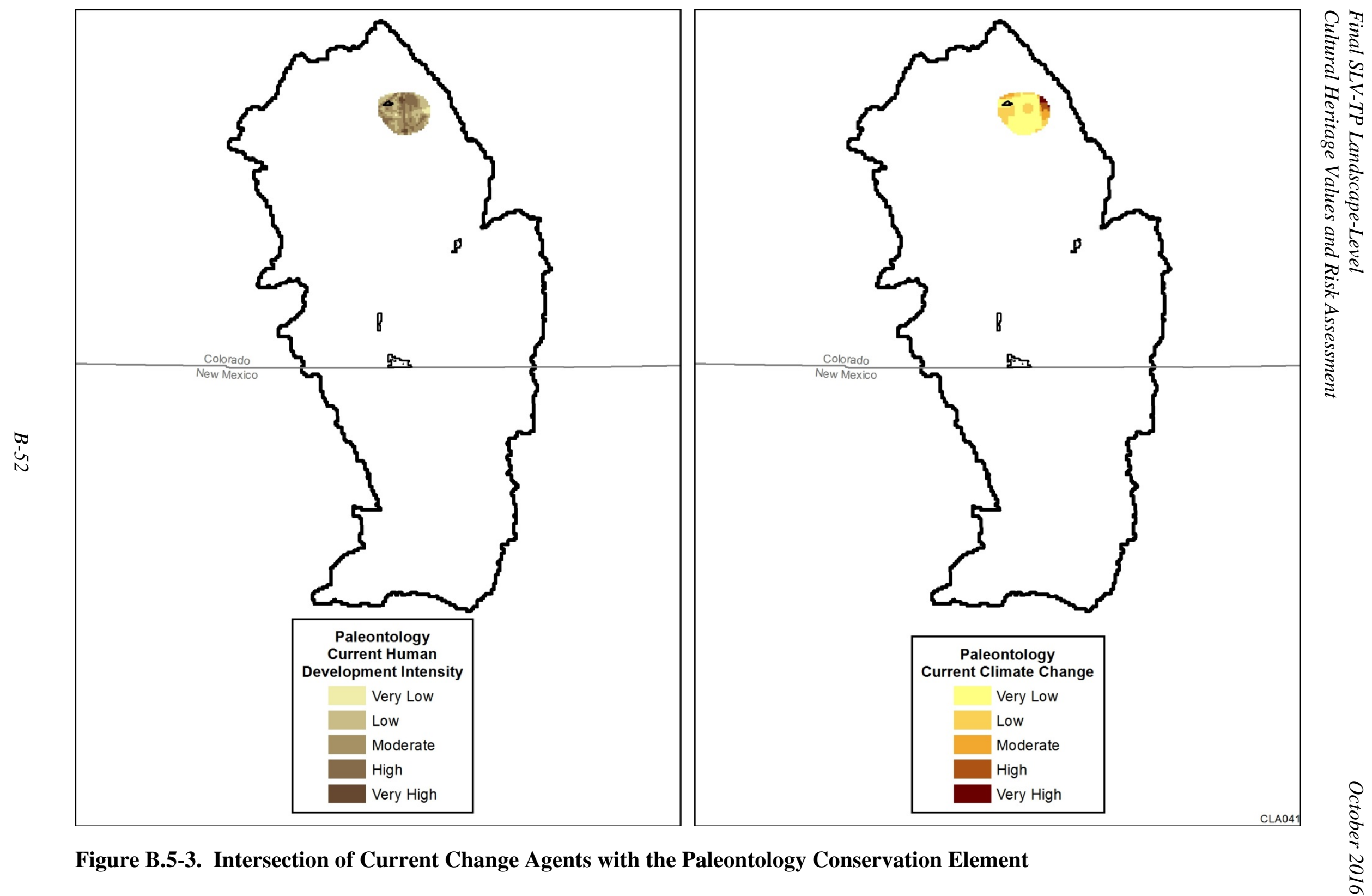

Figure B.5-3. Intersection of Current Change Agents with the Paleontology Conservation Element 

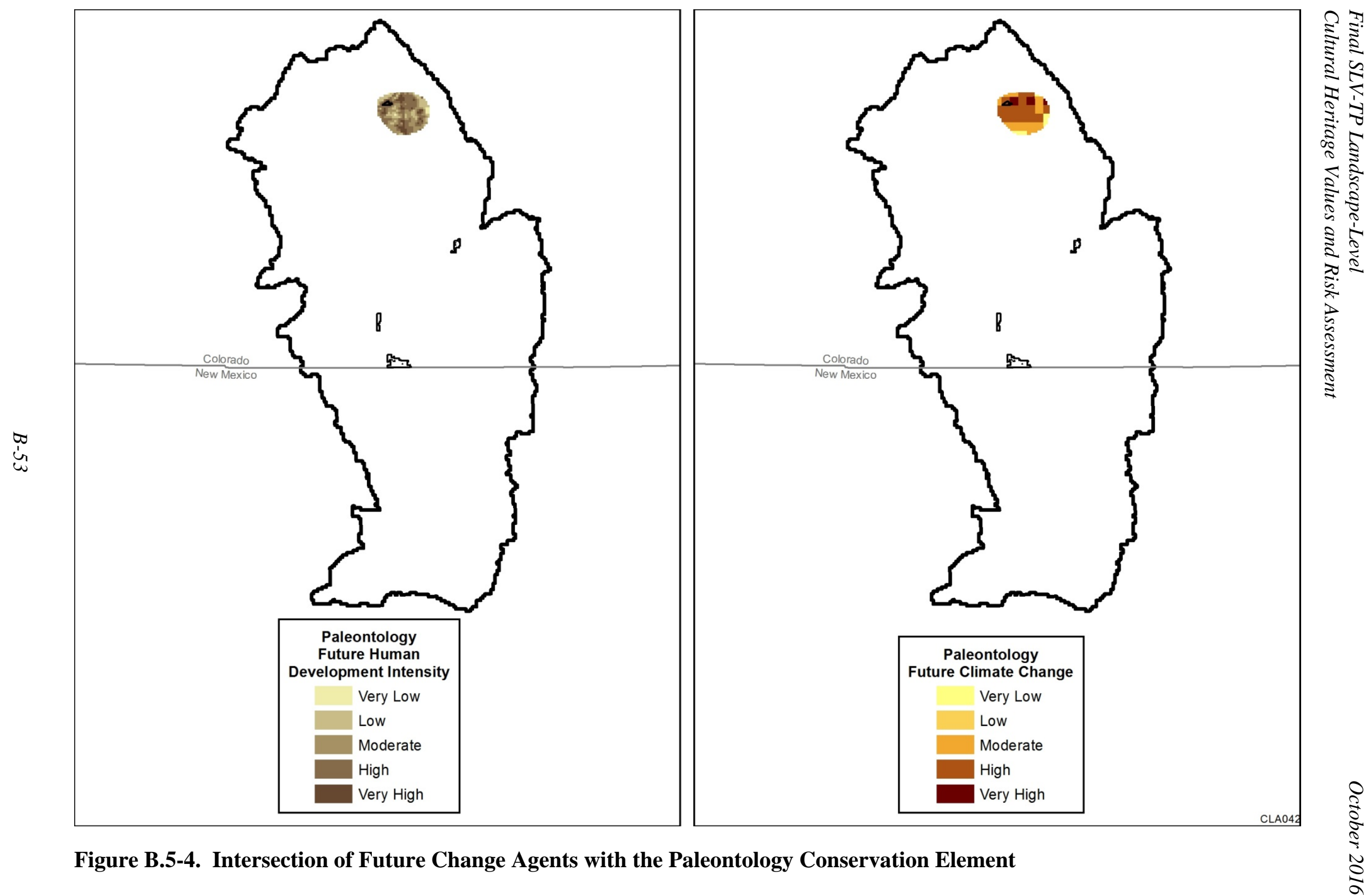

Figure B.5-4. Intersection of Future Change Agents with the Paleontology Conservation Element 

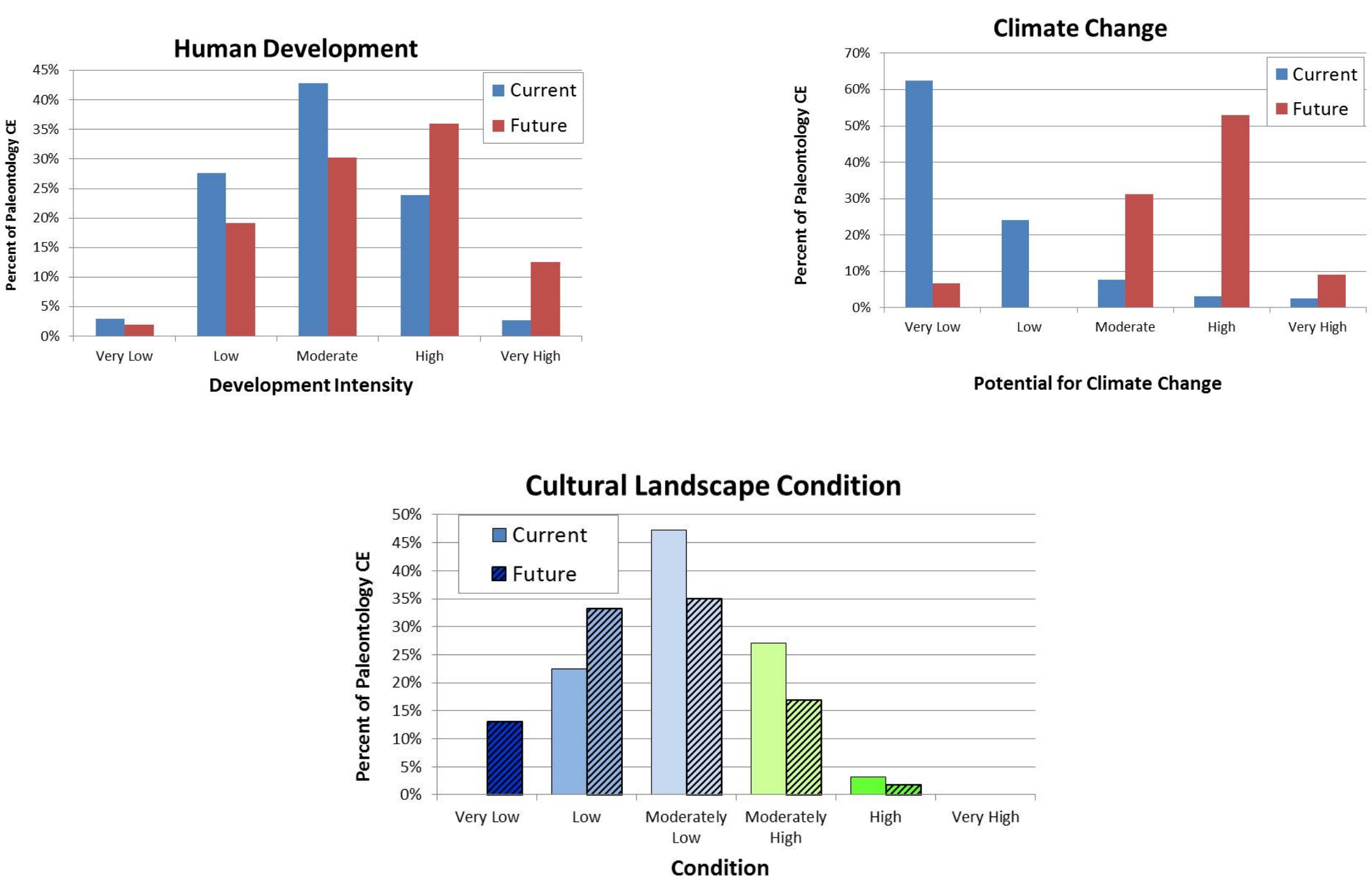

Figure B.5-5. Predicted Trends in the Paleontology Conservation Element within the Study Area 


\section{B.6 Eligible Prehistoric Properties}

This cultural conservation element represents known prehistoric cultural resources that are listed on or eligible for listing on the National Register of Historic Places (NRHP) or State Register. Many of these sites fall within the Biedell or La Jara archaeological districts and consist of open architectural sites, open camps, sheltered camps, open lithic sites, lithic scatters, ceramic scatters, rock art, burials, representing the Paleoindian through historic periods. A total of 1,939 prehistoric sites were evaluated for the regional cultural assessment. In addition, the Rio Grande del Norte National Monument is also included. Many sites within the monument have yet to be recorded and all cultural resources in the monument are considered eligible, so the entire unit has been identified as both an eligible prehistoric and eligible historic property.

Figure B.6-1 shows the spatial distribution of eligible prehistoric properties, and Figure B.6-2 illustrates current and future cultural landscape condition for those prehistoric properties based on the modeling described in Section 4.2.2. Figures B.6-3 and B.6-4 provide the distribution of eligible prehistoric properties intersected with each of the change agents separately at current and future conditions, respectively. The change agent models are identical to those used for the Landscape Assessment and details on their derivations are described in full in that document (Walston et al. 2016). The bar graphs in Figure B.6-5 (based on data presented in Table B-2) are intended to show the trends from current condition to future condition based on percentage of area affected. For example, areas of high and very high density of invasive species, insects, and disease within the distribution of the eligible prehistoric properties are expected to increase by approximately $22 \%$ in the near-term future (i.e., by 2030). Areas of high and very high climate change (changes in temperature and precipitation) show a slightly lesser increase of about $17 \%$ across the area by 2060 . Many of the same areas with high potential for experiencing climate change are also the same areas experiencing increased potential for invasive species, insects, and disease. Changes in human development appear to be minor with about a $2 \%$ increase in high and very high development intensity. While wildfire potential increases from very low to low and moderately low, there is very little change occurring at moderately high and high occurrence density levels; in fact high occurrence levels are projected to decrease from current historic levels by $2 \%$. Very little change (approximately $2 \%$ reduction) in landscape condition for these areas of eligible prehistoric properties has been identified in the near-term future; however, the majority of the area has been identified as low condition, likely as a result of the extensive road network in the area. 


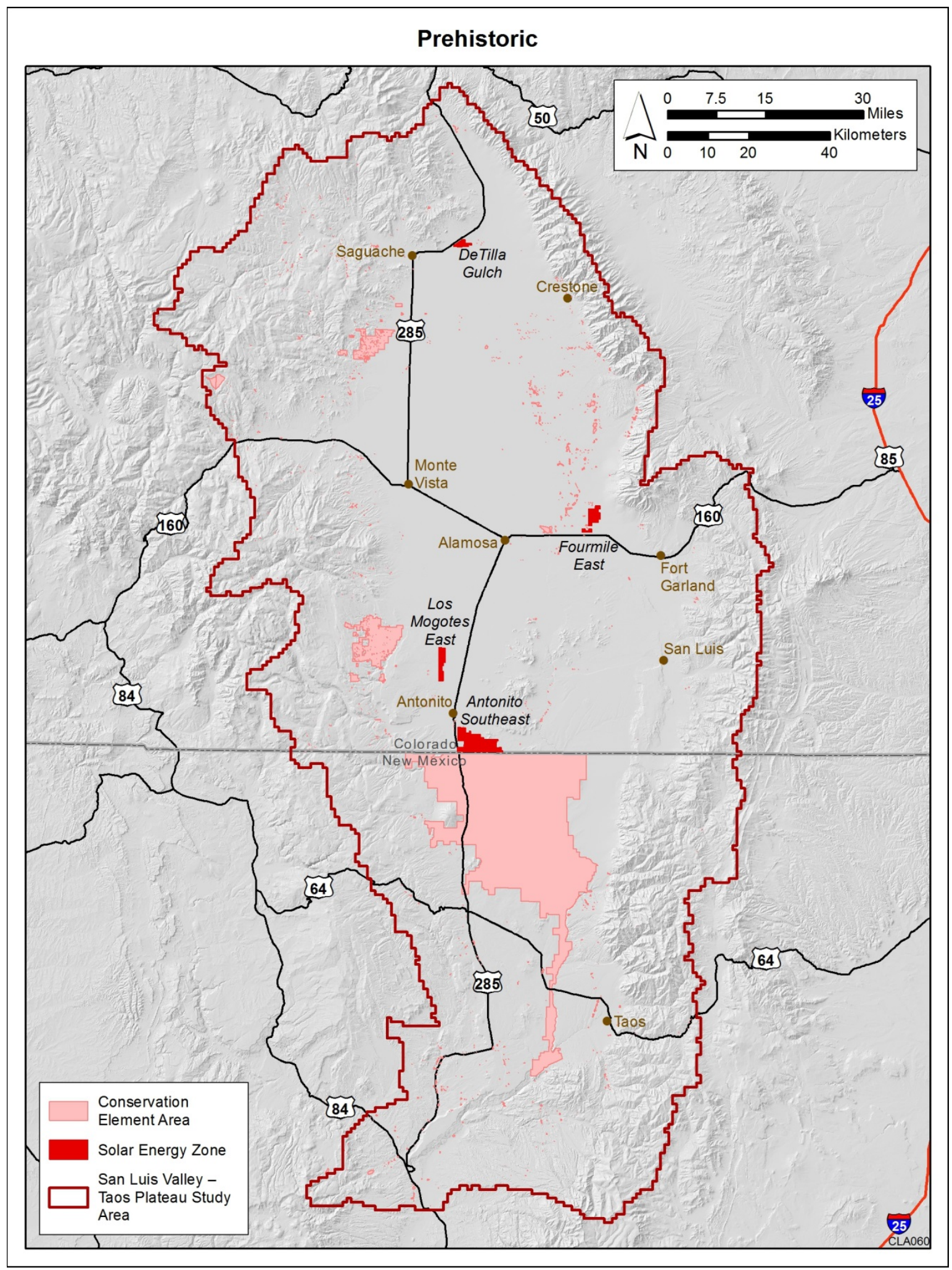

Figure B.6-1. Current Distribution of Eligible Prehistoric Properties 


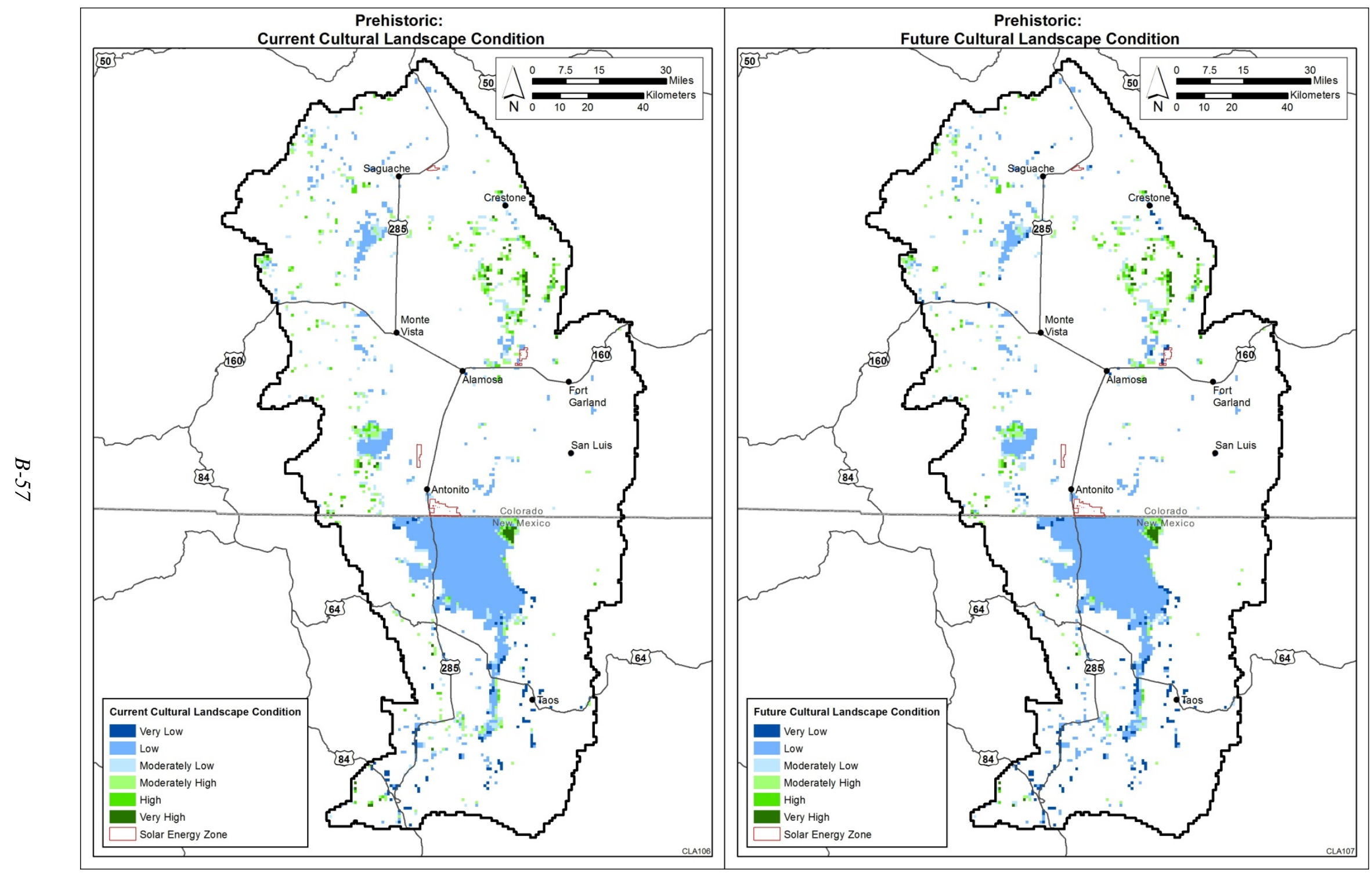

Figure B.6-2. Current and Future Landscape Condition of Eligible Prehistoric Properties 

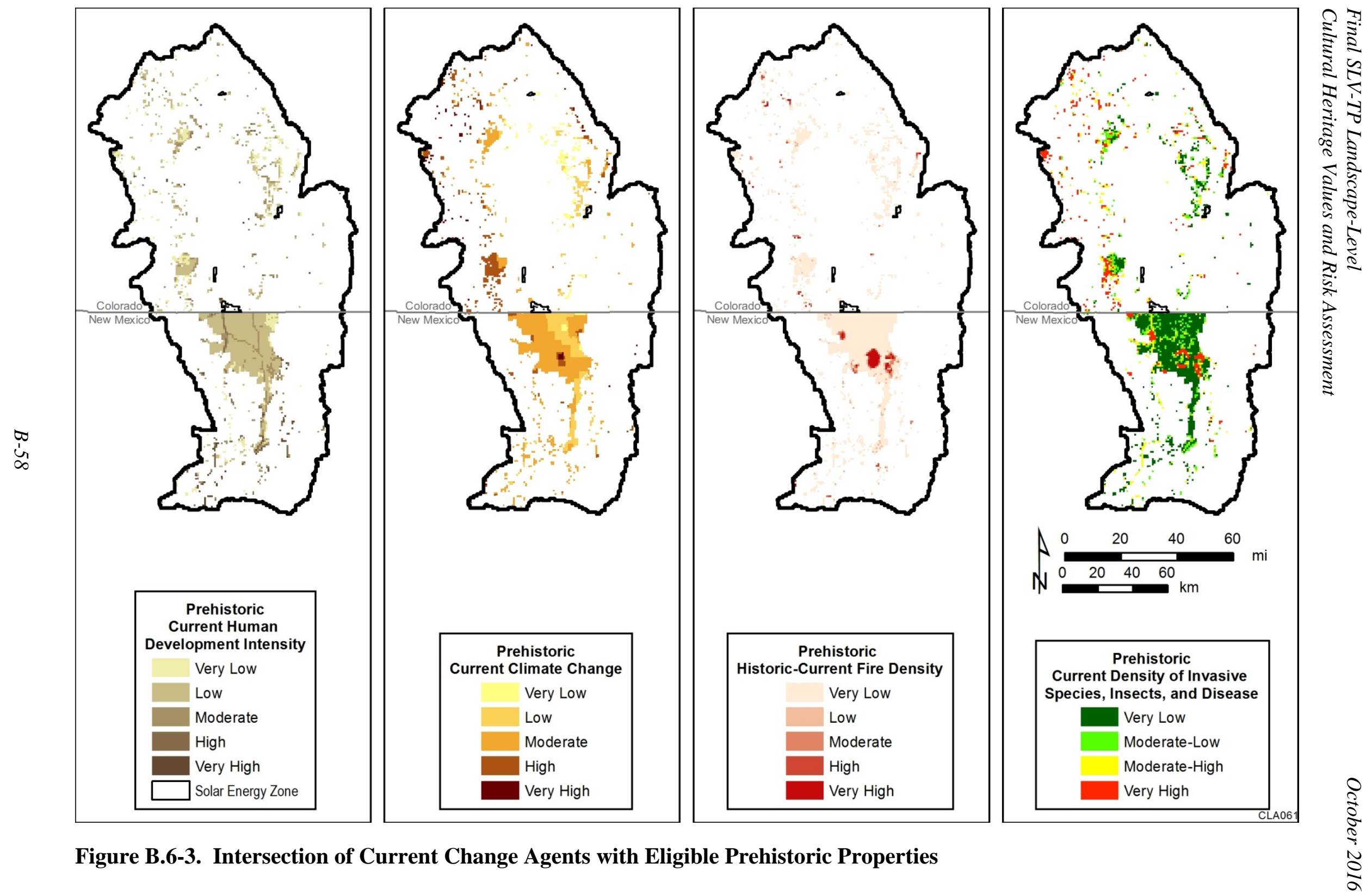

Figure B.6-3. Intersection of Current Change Agents with Eligible Prehistoric Properties 

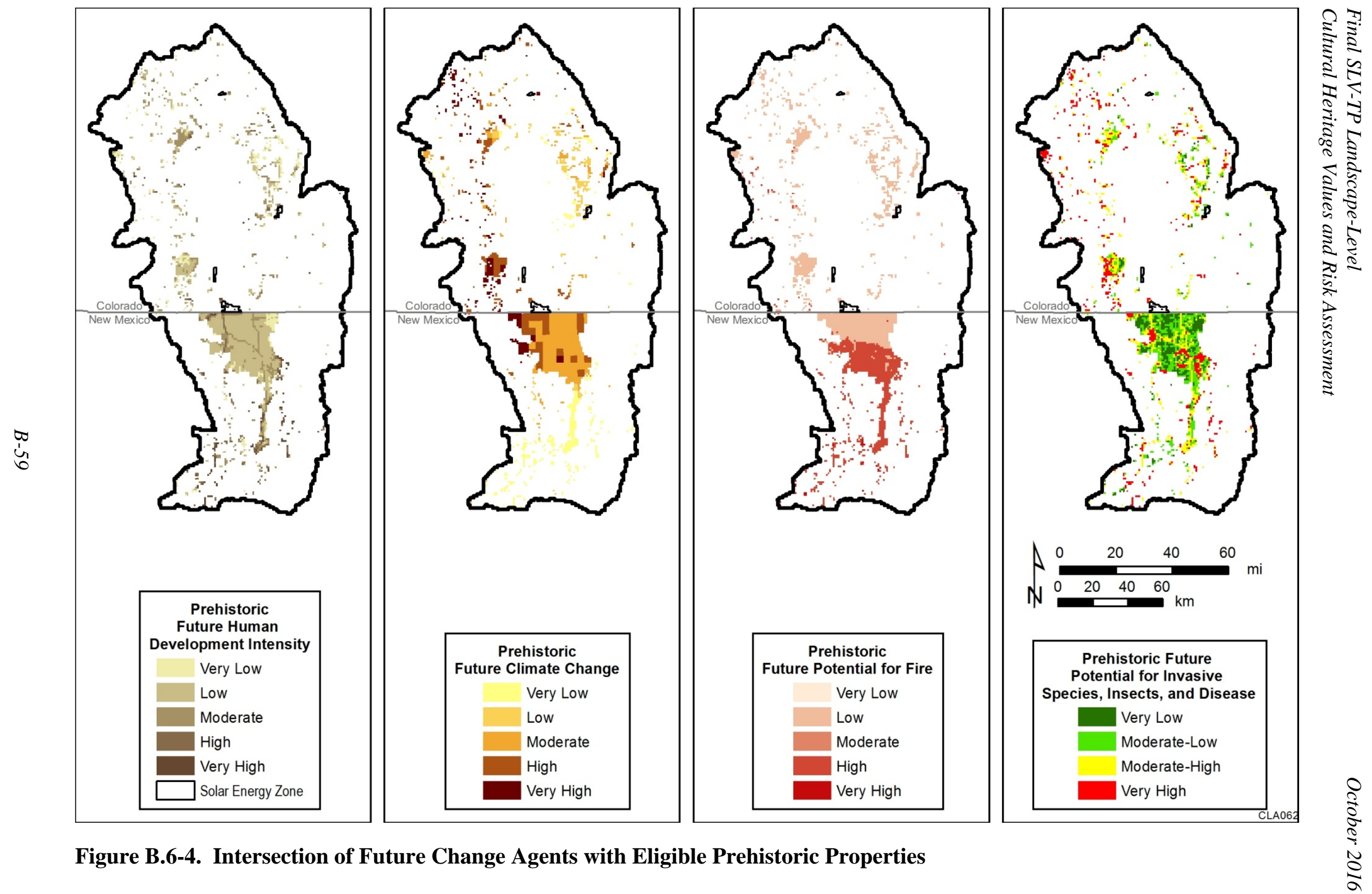

Figure B.6-4. Intersection of Future Change Agents with Eligible Prehistoric Properties 

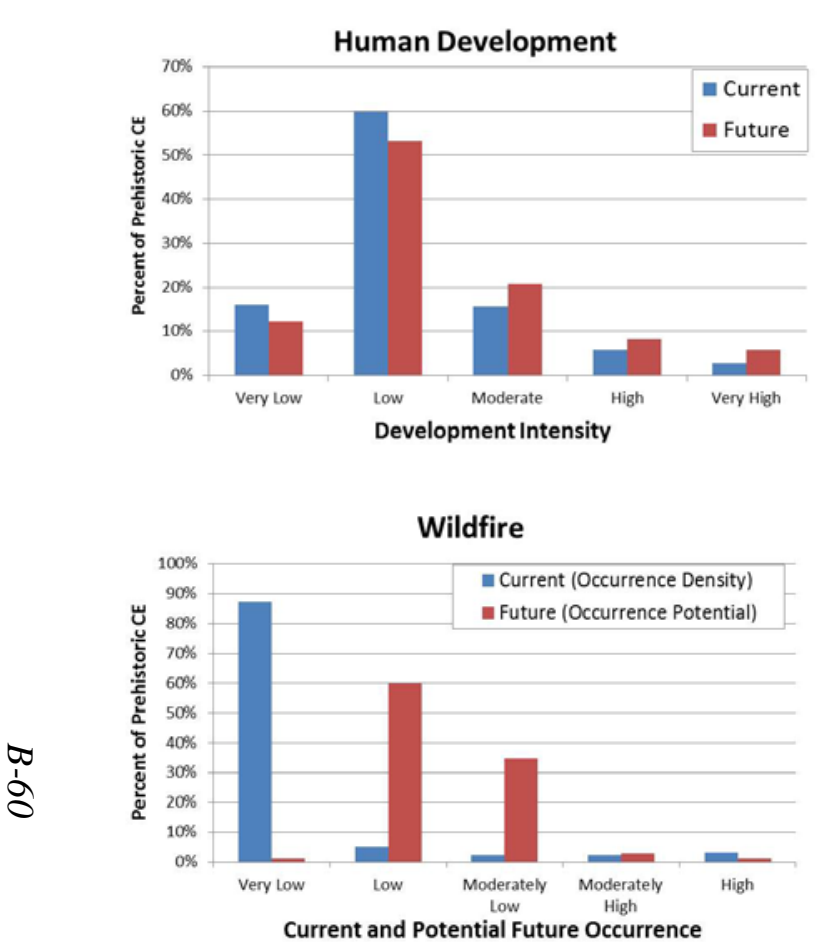

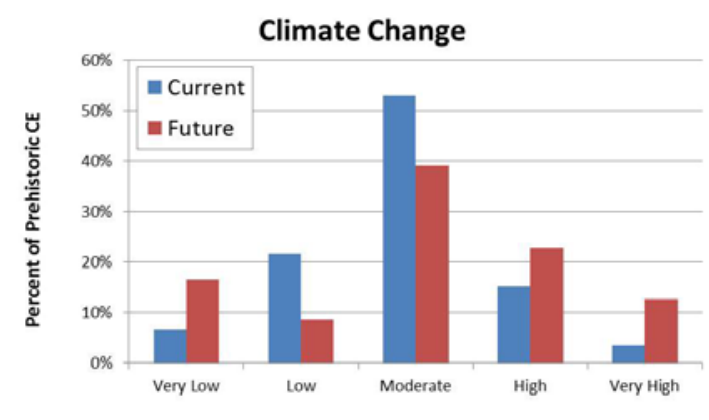

Potential for Climate Change

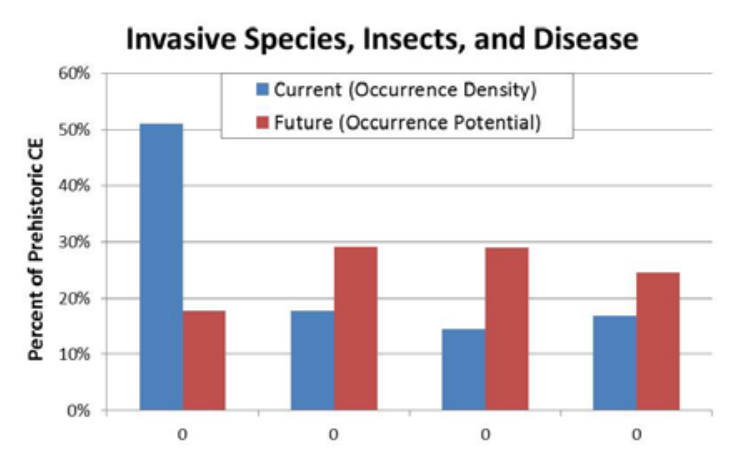

Current and Potential Future Occurrence

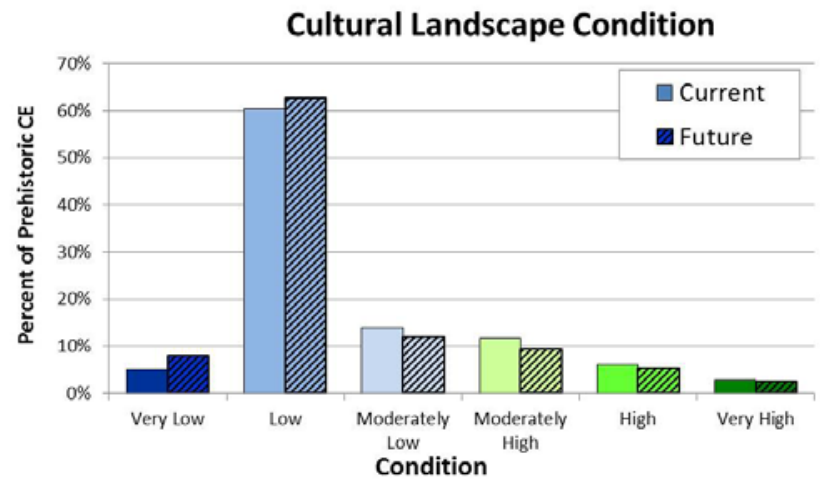

Figure B.6-5. Predicted Trends in the Eligible Prehistoric Properties Conservation Element within the Study Area 


\section{B.7 Eligible Historic Properties}

This cultural conservation element represents historic cultural resources that are listed on or eligible for listing on the NRHP or State Register. These sites are mostly associated with military excursions, early settlements and homesteads, mining, and early urban development. A total of 1,141 historic properties were evaluated for the regional cultural assessment and include eight National Historic Landmarks, a World Heritage Site, military forts, historic homes and buildings, cemeteries, homesteads, townsites, schools, mining cabins and complexes, rock alignments, farm buildings, agricultural and pasture lands, and campsites. In addition, the Rio Grande del Norte National Monument is also included. Many sites within the monument have yet to be recorded and all cultural resources in the monument are considered eligible, so the entire unit has been identified as both an eligible prehistoric and eligible historic property.

Figure B.7-1 shows the spatial distribution of eligible historic properties, and Figure B.7-2 illustrates current and future cultural landscape condition for all of the eligible historic properties based on the modeling described in Section 4.2.2. Figures B.7-3 and B.7-4 provide the distribution of eligible historic properties intersected with each of the change agents separately at current and future conditions, respectively. The change agent models are identical to those used for the Landscape Assessment and details on their derivations are described in full in that document (Walston et al. 2016). The bar graphs in Figure B.7-5 (based on data presented in Table B-2) are intended to show the trends from current condition to future condition based on percentage of area affected. Quite similar to the eligible prehistoric properties conservation element (because of the common area of the Rio Grande del Norte National Monument), areas of high and very high density of invasive species, insects, and disease within the distribution of the eligible historic properties are expected to increase by approximately $18 \%$ in the near-term future (i.e., by 2030). Areas of high and very high climate change (changes in temperature and precipitation) show a similar 18\% increase across the area but the time frame is through 2060. Again, as stated earlier in Section B.6, many of the same areas with high potential for experiencing climate change are also the same areas experiencing increased potential for invasive species, insects, and disease. Human development increases approximately 5\% in high and very high development intensity. Again very similar to the prehistoric properties conservation element area, wildfire potential increases from very low to low and moderately low, but there is very little change occurring at moderately high and high occurrence density levels and high occurrence levels are projected to decrease. Very little change in landscape condition for these areas of eligible prehistoric properties has been identified in the near-term future; however, the majority of the area has been identified as low condition, likely as a result of the extensive road network in the area. 


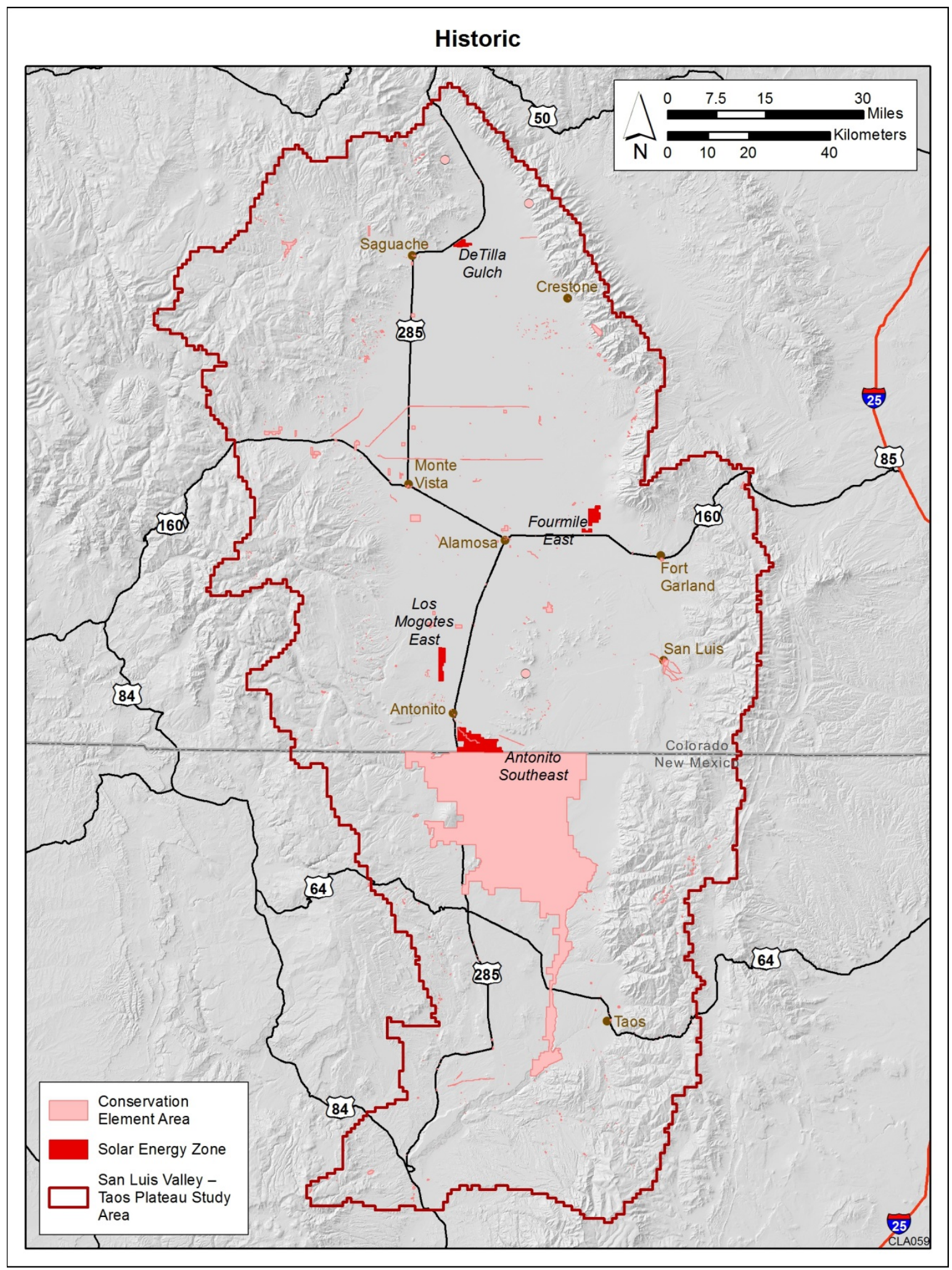

Figure B.7-1. Current Distribution of Eligible Historic Properties 


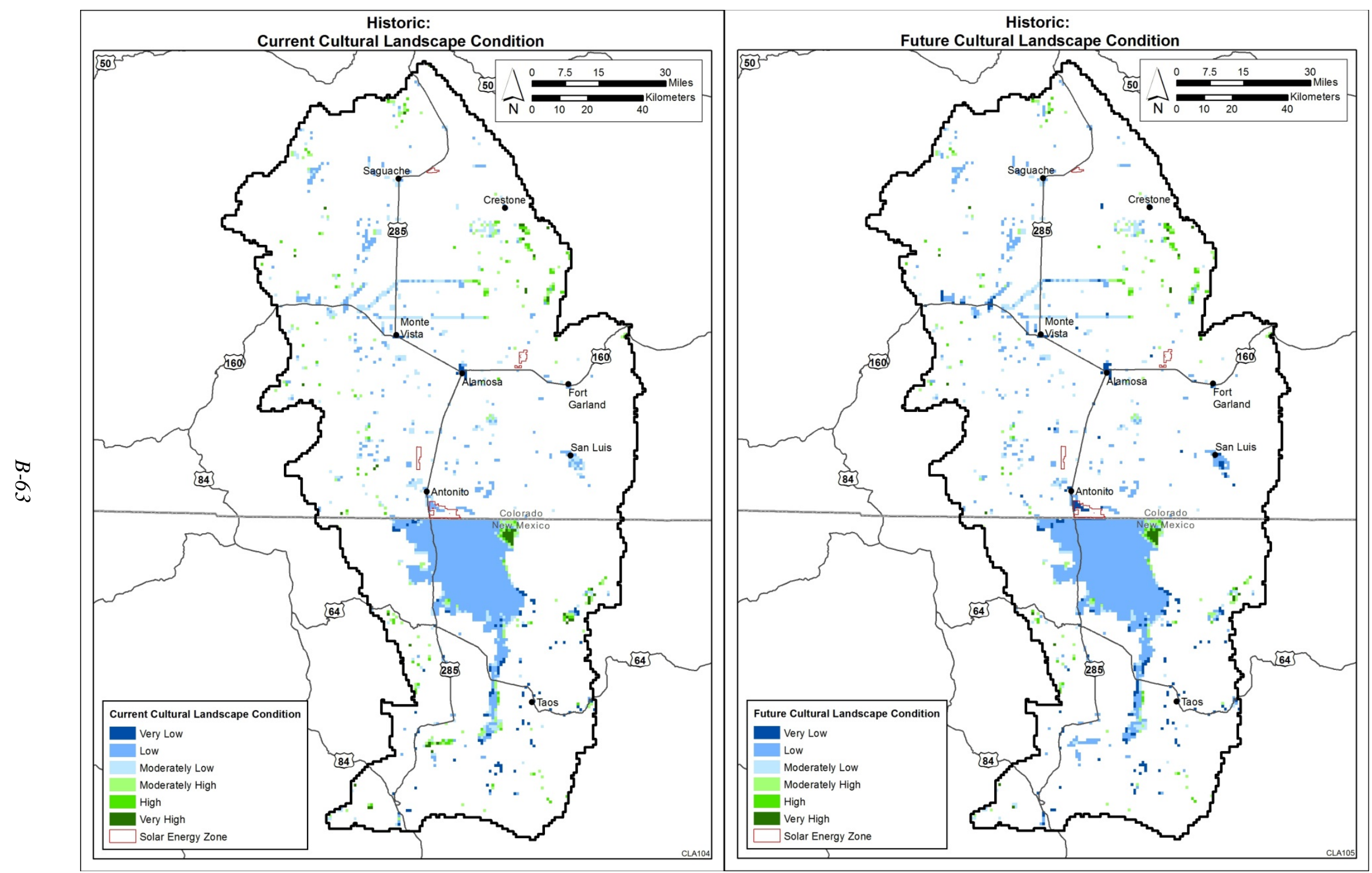

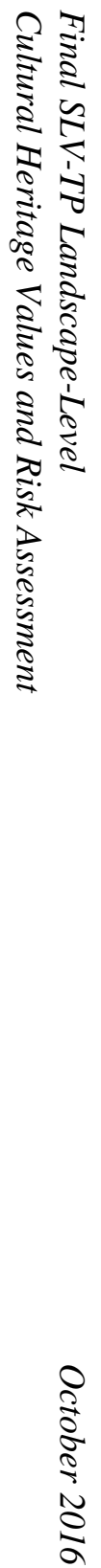

Figure B.7-2. Current and Future Landscape Condition of Eligible Historic Properties 

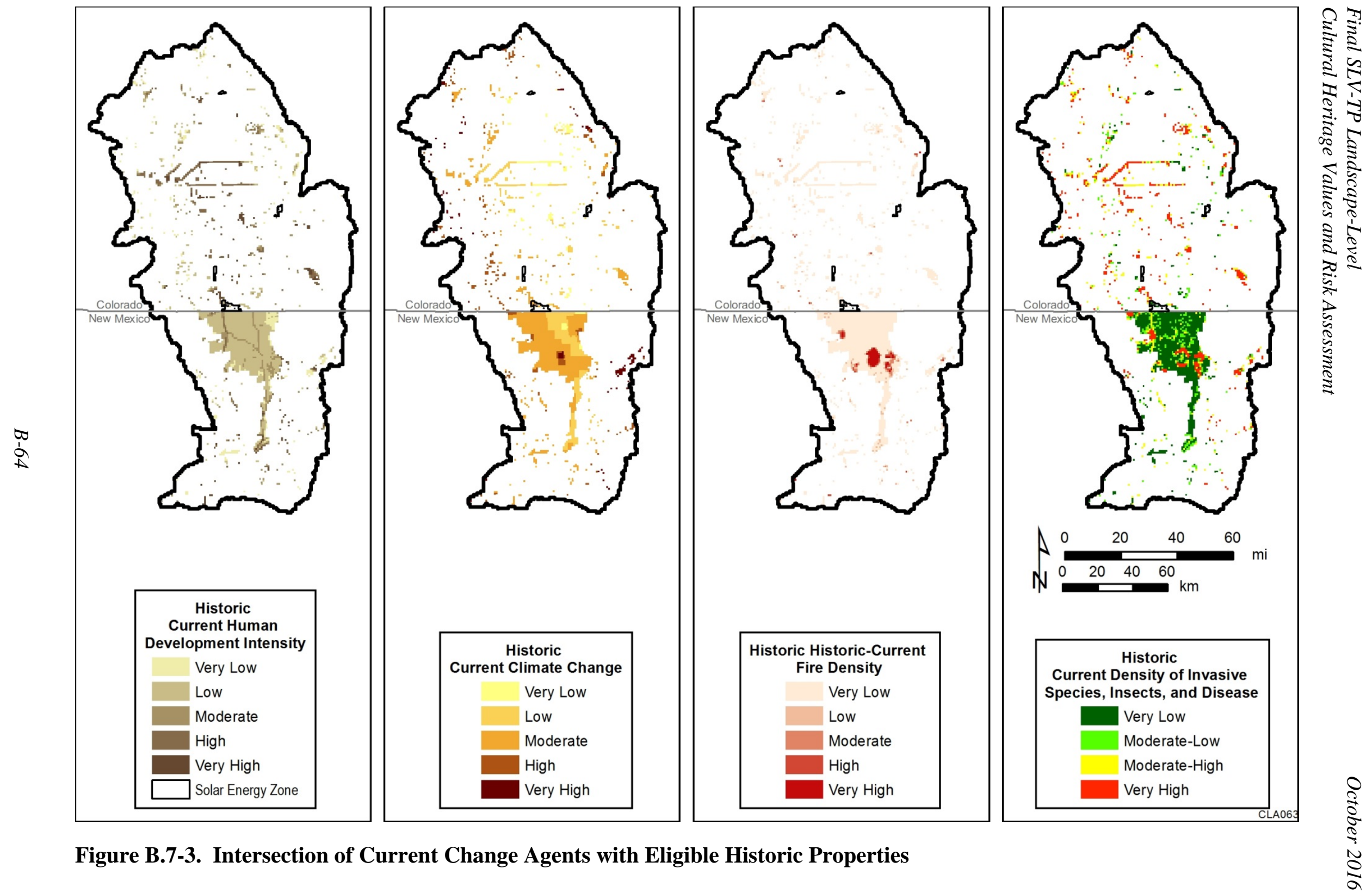

Figure B.7-3. Intersection of Current Change Agents with Eligible Historic Properties 

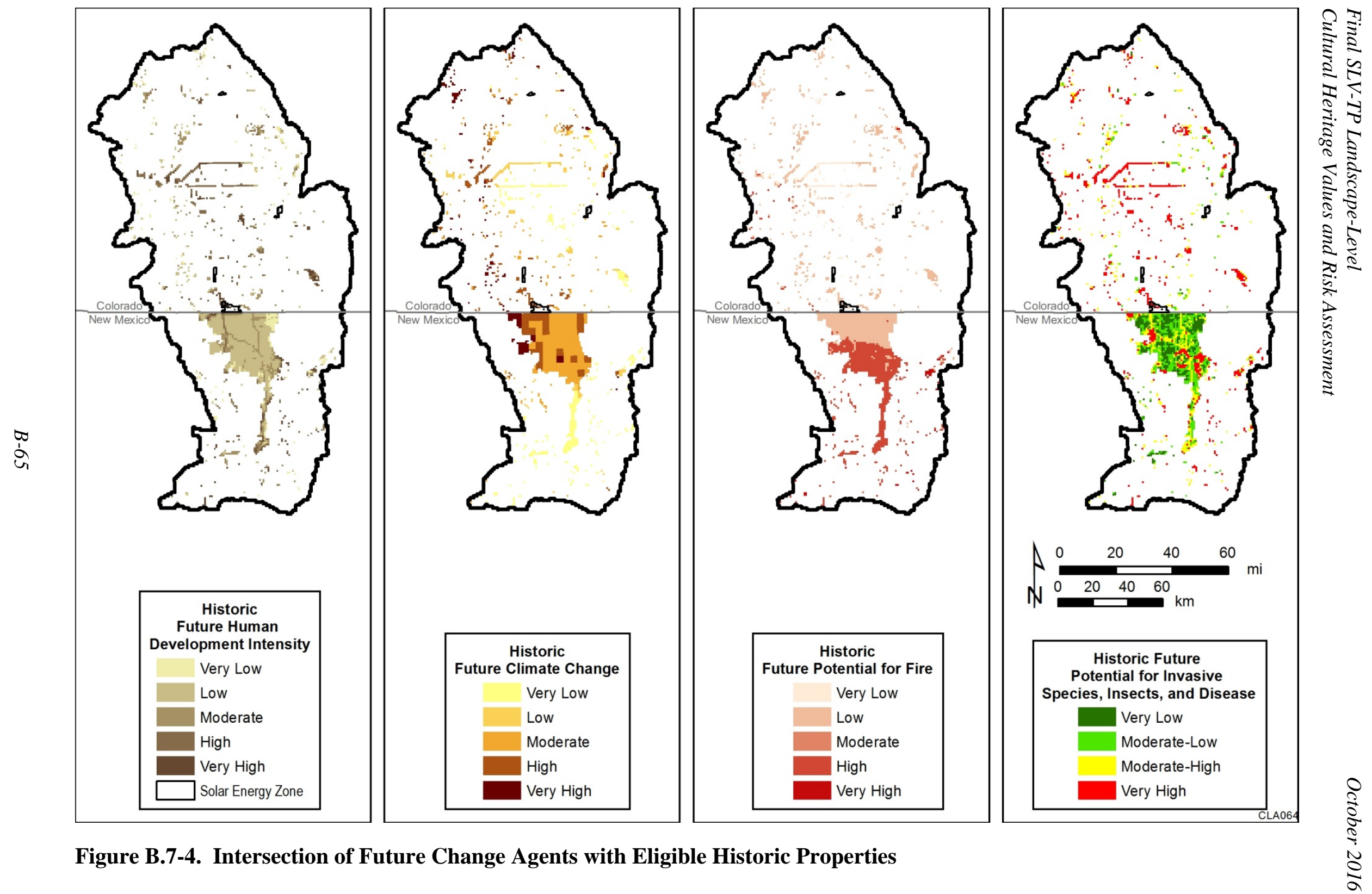

Figure B.7-4. Intersection of Future Change Agents with Eligible Historic Properties 

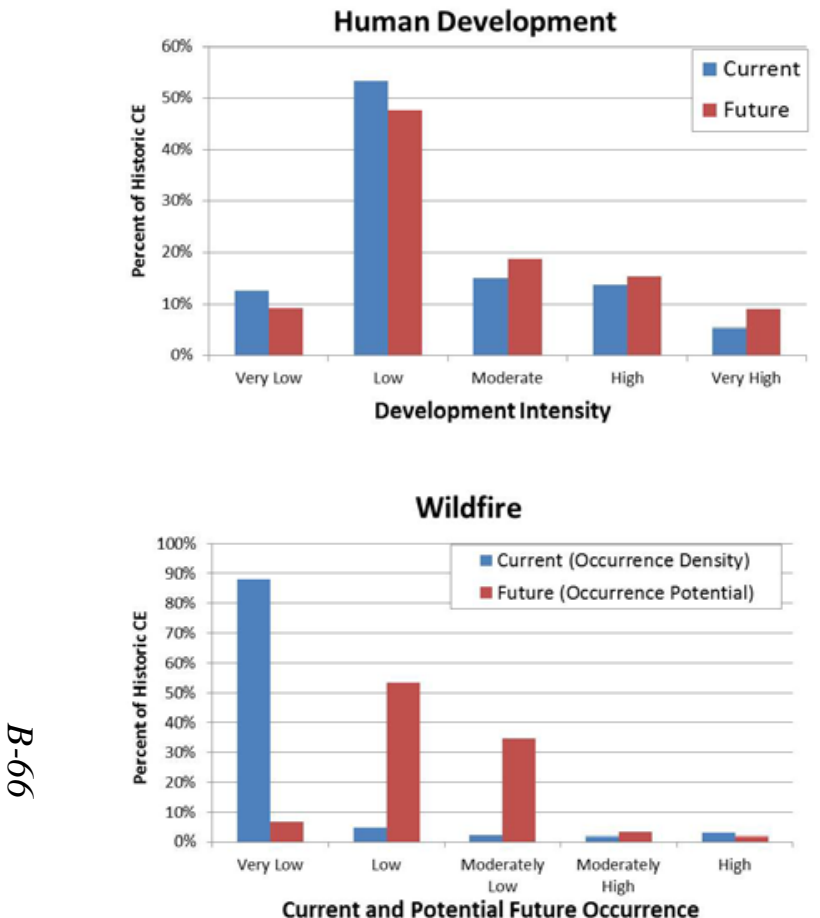

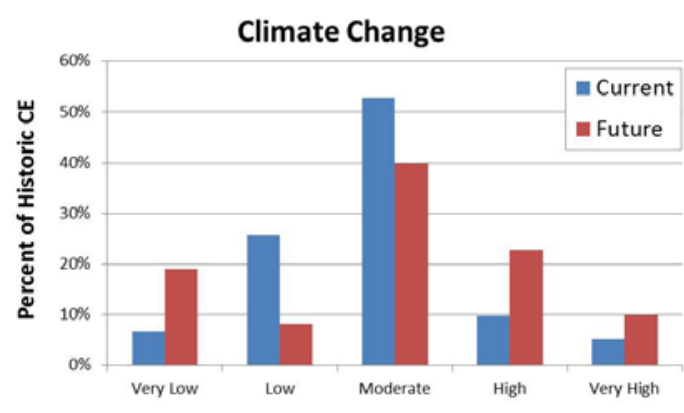

Potential for Climate Change

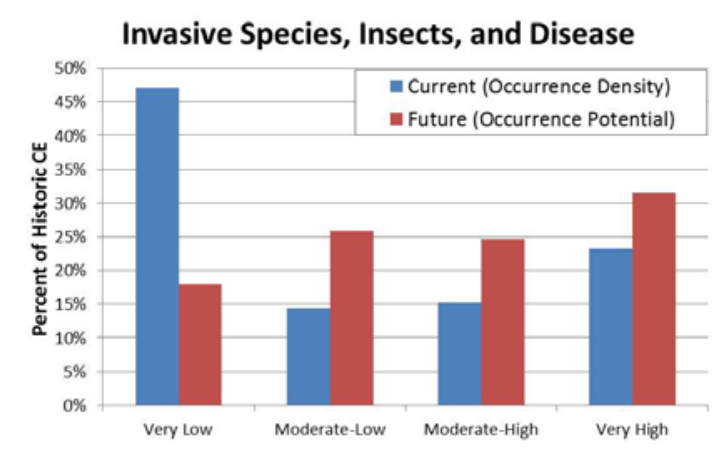

Current and Potential Future Occurrence

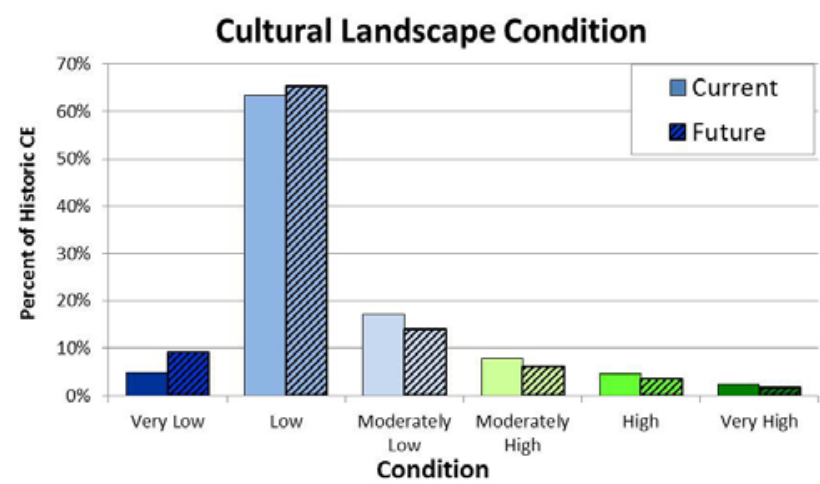

Figure B.7-5. Predicted Trends in the Eligible Historic Properties Conservation Element within the Study Area 
Argonne

Environmental Science Division

Argonne National Laboratory

9700 South Cass Avenue, Bldg. 240

Argonne, IL 60439-4854

www.anl.gov 